\author{
UNIVERSIDADE DE SÃO PAULO \\ Faculdade de Filosofia, Letras e Ciências Humanas \\ Departamento de Linguística
}

Programa de Pós-Graduação em Semiótica e Linguística Geral

PATRÍCIA DE SOUZA BORGES

\title{
Línguas africanas e português brasileiro: análise historiográfica de fontes e métodos de estudos no Brasil (séc. XIX-XXI)
}

Versão corrigida 


\author{
UNIVERSIDADE DE SÃO PAULO \\ Faculdade de Filosofia, Letras e Ciências Humanas \\ Departamento de Linguística \\ Programa de Pós-Graduação em Semiótica e Linguística Geral
}

\title{
Línguas africanas e português brasileiro: análise historiográfica de fontes e métodos de estudos no Brasil (séc. XIX-XXI)
}

Versão corrigida

Patrícia de Souza Borges

Dissertação de mestrado apresentada ao programa de Pós-Graduação em Semiótica e Linguística Geral da Faculdade de Filosofia, Letras e Ciências Humanas da Universidade de São Paulo como requisito para obtenção do título de mestre em Letras. 


\section{Folha de aprovação}

Autora: $\quad$ BORGES, P.S. (Patrícia de Souza Borges)

Título: Línguas africanas e português brasileiro: análise historiográfica de fontes métodos de estudos no Brasil (séc. XIX-XXI)

Aprovado em:

Dissertação de mestrado apresentada ao programa de Pós-Graduação em Semiótica e Linguística Geral da Faculdade de Filosofia, Letras e Ciências Humanas da Universidade de São Paulo como requisito para obtenção do título de mestre sob orientação da $\operatorname{Prof}^{\mathrm{a}} \operatorname{Dr}^{\mathrm{a}}$ Olga Coelho

Banca Examinadora

Prof $^{\mathrm{a}}$ Dr $^{\mathrm{a}}$ Olga Coelho

(Presidente)

Prof $^{\mathrm{a}} \mathrm{Dr}^{\mathrm{a}}$ Beatriz Protti Christino

(Titular)

Prof $^{\mathrm{a}} \mathrm{Dr}^{\mathrm{a}}$ Margarida Maria Taddoni Petter

(Titular)

$\operatorname{Prof}^{\mathrm{o}} \mathrm{Dr}^{\mathrm{o}}$ Dante Eustachio Lucchesi Ramacciotti

(Suplente)

Prof $^{\mathrm{a}}$ Dr $^{\mathrm{a}}$ Lilian do Rocio Borba

(Suplente)

$\operatorname{Prof}^{\mathrm{a}} \operatorname{Dr}^{\mathrm{a}}$ Esmeralda Vailati Negrão

(Suplente) 
Aos meus pais,

José e Marlene.

E ao Lucas. 


\section{AGRADECIMENTOS}

Agradeço,

Primeiramente a Deus pelo dom da minha vida;

Aos meus pais, José e Marlene pelo apoio e amor incondicional. Agradeço também o carinho e incentivo de minha irmã Keylla, de meu cunhado Expedito, de meus padrinhos Maria Cleuza e Dirço, de meus avós queridos e de meus familiares;

Ao Lucas, pelo amor, alegria e colorido que dá a minha existência;

À minha orientadora Olga pela orientação na pesquisa e amizade na vida;

Às Professoras Cristina Altman e Margarida Petter pelas recomendações e críticas na banca de qualificação e por acompanharem minha pesquisa;

Ao Professor Pierre Swiggers pelo envio de textos fundamentais nesta pesquisa e ao Professor Emilio Bonvini pelo incentivo dado a minha pesquisa de Iniciação Científica;

À família Jaguaré: Janayna Carvalho, Jéssica Costa e Larissa Fernandes pela convivência diária nas alegrias e dores e pela imensa ajuda no desenvolvimento desta dissertação;

À Julia de Crudis, Bianca Fraga, Lilian Nery e Márcia de Oliveira pela amizade e carinho que só crescem com o passar dos anos;

Aos meus companheiros de USP: Julia Pontes, Wallace Bernardo, Paulo Monteiro e Renan Viani por compartilhar o caminho;

Aos meus colegas (e amigos) pesquisadores do CEDOCH: Adan Cunha, Bruna Polachini, Jéssica Luiz, Lygia Raquel, Mariana Viel, Stela Danna, Roberta Ragi e Wellington Silva pelos ricos momentos de estudo em Historiografia Linguística;

Aos meus companheiros de estudo de Kiswahili e a minha professora de Kiswahili Juliana Macek por compartilhar o interesse em aprender e ensinar uma língua africana;

Aos meus alunos e colegas de trabalho no Colégio São Luís por me ensinarem o amor pela docência;

Aos funcionários do Departamento de Linguística (DL/USP) pela ajuda com as tarefas administrativas e aos coordenadores do Programa de Pós-Graduação em Linguística do Departamento de Linguística, no período em que fui aluna, Professora Olga Coelho e Professor Marcos Lopes.

Ao Conselho Nacional de Desenvolvimento e Pesquisa (CNPq) pela bolsa a mim concedida. 


\section{RESUMO}

BORGES, Patrícia de Souza. Línguas africanas e português brasileiro: análise historiográfica de fontes e métodos de estudos no Brasil (séc. XIX-XXI). 2014. 238f. Dissertação (Mestrado) - Faculdade de Filosofia, Letras e Ciências Humanas, Universidade de São Paulo, São Paulo, 2014.

As relações entre as línguas africanas e o português brasileiro é tema recorrente nos estudos linguísticos produzidos no Brasil, desde o século XIX ( $c f$., por exemplo, Macedo Soares 1942[1874/1891]) e parece estar em evidência no panorama contemporâneo, como o demonstra o número de trabalhos recentemente publicados. Ao analisar a história desta produção linguística, Bonvini (2009) propõe que os trabalhos produzidos podem ser distinguidos em duas tendências: 'influência' e 'crioulização'. Segundo ele, ambas as hipóteses sobre essas relações apresentam deficiências, especialmente quanto a dois aspectos: o tratamento das fontes e a metodologia de estudos empregada. Quanto às fontes, os trabalhos teriam sido formulados sem apoio em dados linguísticos precisos e identificados. Quanto à metodologia, as análises estariam centradas em aspectos léxico-semânticos ou morfossintáticos, níveis que Bonvini julga inadequados para tratar a questão. A partir dessas críticas, cumpre indagar: quais foram as fontes usadas nos trabalhos sobre as relações entre as línguas africanas e o português brasileiro? Toda a produção sobre o tema desenvolveu-se a partir dos mesmos princípios metodológicos? Houve mudanças no tratamento do tema: da hipótese da "influência" à "crioulização"? Nosso projeto teve como objetivos mapear e analisar a produção que investigou as relações entre o português brasileiro e as línguas africanas no Brasil e discutir a periodização para a história dessa produção. Tal análise foi baseada no conceito de 'programa de investigação', proposto por Swiggers (1981a, 1991a, 2004). Esse conceito permite distinguir e agrupar trabalhos produzidos sob diferentes teorias e em épocas distintas, uma vez que destaca sua natureza interna, isto é, a maneira de os estudiosos lidarem com um mesmo objeto de investigação. Assim analisamos essa produção a partir dos parâmetros de análise que definem um 'programa de investigação': 'visão' (concepção de linguagem adotada, tipos de materiais de destaque e modos de conceber as relações entre linguagem e sociedade, linguagem e cultura, etc.), 'técnica' (conjunto de princípios e métodos adotados) e 'incidência' (formas linguísticas de análise privilegiadas e a natureza e função preferencialmente atribuídas a essas formas). $\mathrm{O}$ estudo desses três aspectos permitiu sinalizar tendências gerais na área do século XIX ao XXI: uma tendência sociocultural baseada na análise lexical e uma tendência híbrida, sociocultural e descritivista, cujo centro da análise é a sintaxe e a morfossintaxe. $O$ percurso de pesquisa ainda permitiu elaborar uma bibliografia de textos fundamentais para o tratamento do tema nesses séculos.

Palavras-Chave: Historiografia Linguística; Português Brasileiro; Línguas Africanas; Contato Linguístico. 


\section{ABSTRACT}

BORGES, Patrícia de Souza. African languages and Brazilian Portuguese: a historiographical analysis of sources and study methods in Brazil (19th-21st centuries). 2014. 238f. Master's Thesis (Dissertação de Mestrado) - Faculdade de Filosofia, Letras e Ciências Humanas, Universidade de São Paulo, São Paulo, 2014.

The relations between African languages and Brazilian Portuguese are recurrent in the linguistic studies conducted in Brazil since the $19^{\text {th }}$ century $(c f$., for example, Macedo Soares 1942[1874/1891]) and they are in evidence in the current scenario, as many works in the field have been recently published. When analysing the history of this linguistic production, Bonvini (2009) proposes that his work can be categorised into two trends: 'influence' and 'creolization'. According to him, both hypotheses on those relations present inaccuracies, especially regarding two aspects: the treatment of the sources and the research methodology adopted. As for the sources, the works would have been carried out without the support of identified accurate linguistic data. With regard to the methodology, the analyses revolved around lexical-semantic or morphosyntactic aspects, level considered inadequate by Bonvini to approach the subject. Based on those criticisms, the following questions are raised: what were the sources adopted in the investigations on the relations between African languages and Brazilian Portuguese? Has all the production on the subject been developed from the same methodological principles? Have there been changes in the treatment of the subject: of the hypothesis from the "influence" to the "creolization"? Our project aimed at tracking and analysing the production that investigated the relations between Brazilian Portuguese and the African languages in Brazil, and also the discussion on the periodization for the history of this production. Such an analysis was based on the concept of 'research program', put forward by Swiggers (1981a, 1991a, 2004). This concept enables the historiographer to distinguish and group research works produced under different theoretical approaches and from different periods, as it highlights their inner aspects, that is, the way in which scholars deal with the same object of investigation. By doing so, we analysed this production based on the parameters of analysis which define our 'research program': 'view' (view of language adopted, types of materials and ways of conceiving the relations between language and society, language and culture, etc.) 'technique' (combination of principles and methods adopted) and 'incidence' (linguistic forms of analysis which were privileged, as well as the nature and function preferably attributed to those forms. The study of those three aspects allowed us to point out the general trends in the field from the 19th to the 21st century: a sociocultural trend based on lexical analysis and a hybrid trend, sociocultural and descriptivist, the center of the analysis is the syntax and morphosyntax. The research course have also allowed it to prepare a bibliography of fundamental texts in order to discuss the topic in these centuries.

Key-words: Linguistic Historiography; Brazilian Portuguese; African Languages; Linguistic Contact 


\section{Lista de tabelas, quadros e figuras}

Seções

Página

Quadro-resumo 3.1: Quantificação de textos por décadas

Quadro 4.1: Estrutura da obra Estudos lexicográficos do dialeto brasileiro

Quadro 4.2: Estrutura da obra A influência africana no Português do Brasil (1935[1933])

Quadro 4.3: 'Horizonte de retrospecção' de Mendonça 1935[1933]

Quadro 4.4: Estrutura da obra $O$ elemento afro-negro na língua portuguesa (1933)

Quadro 4.5: 'Horizonte de retrospecção' de Raimundo (1933)

Quadro 4.6: Estrutura da obra Introdução ao estudo da língua portuguesa no

Brasil (1950)

Quadro 5.1: Estrutura da obra Origens do português brasileiro

Quadro 5.2: Estrutura da obra Variedades linguísticas em contato: português

angolano, português brasileiro, português moçambicano (2008)

Quadro 5.3: Estrutura do artigo "African Languages and Brazilian Portuguese: a new approach"

Quadro 5.4: Referências explícitas em Castro (2009)

Quadro 5.5: Quadro da Língua de santo e de seu sistema lexical

Quadro 5.6: Estrutura da obra O Português Afro-brasileiro (2009)

Tabela 5.1. Marcas explícitas de plural nos elementos do SN em função da variável posição em relação ao núcleo do SN e posição linear a partir da esquerda - Dados de 64 falantes do Rio de Janeiro: amostra PEUL da década de 1980. (Naro \& Scherre 2007: 43) 


\section{SUMÁRIO}

Seções

Página

Introdução

Capítulo 1: Bases teóricas

16

1.1 'Historiografia', 'Epi-Historiografia' e 'Meta-Historiografia' dos

estudos da relação do PB com as línguas africanas

1.2 Revisitando revisões históricas

19

1.3 Princípios gerais da análise

Capítulo 2: Metodologia e materiais de pesquisa

2.1 Mapeamento da produção brasileira dedicada ao contato do PB com as Línguas Africanas

2.2 'Exemplares' selecionados para a análise historiográfica descritiva

2.3 Parâmetros de análise dos 'exemplares' selecionados

40

2.4 Avaliação dos resultados da análise

41

Capítulo 3: Bibliografia básica da produção brasileira dedicada à relação

3.1 Epi-historiografia das relações do PB com as Línguas Africanas $\quad 42$

3.2 Bibliografia básica sobre a relação entre o PB e as línguas 44

africanas no Brasil, do século XIX ao XXI, em ordem cronológica de publicação

3.3 Observações gerais sobre a bibliografia

Capítulo 4: Obras inaugurais dos estudos do contato do PB com as línguas africanas: Macedo Soares (1942 [1874-1890]), Mendonça (1935 [1933]), Raimundo (1933) e Silva Neto (1950)

4.1 Estudos lexicográficos do dialeto brasileiro (1942[1874-1890]) de

Antônio Joaquim de Macedo Soares [1838 - 1905]

4.1.1 Breve perfil biográfico do autor e visão geral da obra 86

4.1.2 'Horizonte de retrospecção'

4.1.3 'Programa de investigação'

4.1.3.1 'Visão de língua'

4.1.3.2 'Incidência da análise'

4.1.3.3'Fontes'

4.1.3.4'Técnica' 101

4.1.4 Síntese 103

4.2 A influência africana no Português do Brasil (1935[1933]) de 104

Renato Firmino Maia de Mendonça [1912 - 1990]

4.2.1 Breve perfil biográfico e visão geral da obra 104

$\begin{array}{ll}4.2 .2 \text { 'Horizonte de retrospecção' } & 107\end{array}$

4.2.3 'Programa de investigação' 108

4.2.3.1 'Visão de língua' 108

4.2.3.2'Incidência' 110

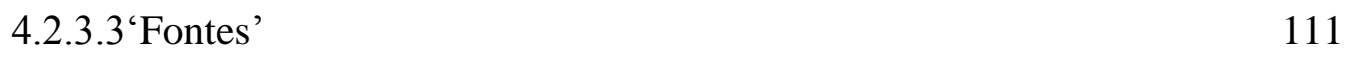

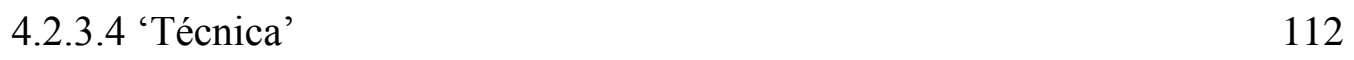

4.2.4 Síntese 113

4.3 O elemento afro-negro da língua portuguesa (1933), de Jacques 114

Raimundo Ferreira da Silva [ ?- 1960?] 
4.3.1 Breve perfil biográfico do autor e visão geral da obra 114

4.3.2 'Horizonte de retrospecção' 115

4.3.3 'Programa de investigação' 117

4.3.3.1 'Visão de língua' 117

4.3.3.2 'Incidência da análise' 118

$\begin{array}{ll}4.3 .3 .3 \text { 'Fontes' } & 119\end{array}$

4.3.3.4'Técnica' 121

4.3.4. Síntese 122

4.3.5 Síntese comparativa de Mendonça (1935[1933]) e Raimundo 122

(1933)

4.4 Introdução ao estudo da língua portuguesa no Brasil (1950), de 123

Serafim da Silva Neto (1917-1960)

4.4.1Breve perfil biográfico do autor e visão geral da obra 123

4.4.2 'Horizonte de retrospeção' 126

4.4.3 'Programa de investigação' 129

4.4.3.1 'Visão de língua' 129

4.4.3.2 'Incidência da análise' 136

$\begin{array}{ll}4.4 .3 .4^{\prime} \text { 'Fontes' } & 138\end{array}$

$\begin{array}{lr}4.4 .3 .4 \text { 'Técnica' } & 140\end{array}$

4.4.4 Síntese 141

Capítulo 5: Algumas tendências contemporâneas nos estudos do contato do 143 português brasileiro com as línguas africanas

5.1 Contextualização geral 143

5.2. Origens Do Português Brasileiro (2007), de Anthony Julius Naro 145

e Maria Marta Pereira Scherre

5.2.1 Breve perfil biográfico dos agentes e visão geral da obra 145

5.2.2 'Horizonte de retrospecção' 150

5.2.3 'Programa de investigação' 151

5.2.3.1 'Visão de língua' 151

5.2.3.2 'Incidência da análise'

5.2.3.3 'Fontes' 153

5.2.3.4 'Técnica' 155

5.2.4 Síntese 156

5.3. Variedades Linguísticas Em Contato: Português Angolano, 157

Português Brasileiro, Português Moçambicano (2008) de Margarida

Maria Taddoni Petter

5.3.1 Breve perfil biográfico do agente e visão geral da obra 157

5.3.2 'Horizonte de retrospeção' 159

5.3.3'Programa de investigação' 160

5.3.3.1 'Visão de língua' 160

5.3.3.2 'Incidência de análise' 161

5.3.3.3 'Fontes' 162

5.3.3.4 'Técnica' 163

5.3.4 Síntese 163

5.4 "African Languages and Brazilian Portuguese: A new approach", 164

de Yeda Antonita Pessoa de Castro (2009)

5.4.1 Breve perfil biográfico do agente e visão geral da obra 164

5.4.2 'Horizonte de retrospeção' 166

5.4.3'Programa de investigação' 166

5.4.3.1 'Visão de língua' 166 
5.4.3.2 'Incidência' 167

$\begin{array}{ll}\text { 5.4.3.3 'Fontes' } & 168\end{array}$

5.4.3.4 'Técnica' 168

5.4.4 Síntese 169

5.5 O Português Afro-Brasileiro (2009), organizado por Dante 169

Lucchesi, Alan Baxter e Ilza Ribeiro

5.5.1 Perfis biográficos dos agentes e visão geral da obra 169

5.5.2 'Horizonte de retrospeção' 174

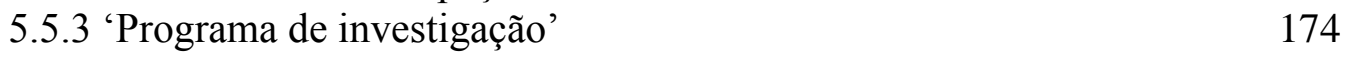

$\begin{array}{ll}\text { 5.5.3.1 'Visão de língua' } & 174\end{array}$

$\begin{array}{ll}\text { 5.5.3.2 'Incidência' } & 175\end{array}$

$\begin{array}{ll}\text { 5.5.3.3 'Fontes' } & 175\end{array}$

$\begin{array}{ll}\text { 5.5.3.4 'Técnica' } & 176\end{array}$

$\begin{array}{ll}\text { 5.5.4 Síntese } & 177\end{array}$

Capítulo 6: Para uma historiografia dos estudos da relação do PB com línguas africanas

6.1. Bibliografia básica da produção brasileira sobre relação do PB 179 com as línguas africanas (Epi-historiografia)

6.2 Análise dos textos 'exemplares' da 'tradição' de estudos do contato do PB com línguas africanas (Historiografia Descritiva)

6.2.1 Perfil biográfico dos autores, constituição geral das obras e contextos de produção e circulação de conhecimento

6.2.2 'Horizonte de retrospecção'

6.2.3 'Programa de investigação' 183

6.2.3.1 'Visão de língua' 183

6.2.3.2 'Incidência de análise' 184

$\begin{array}{ll}\text { 6.2.3.3 'Fontes' } & 184\end{array}$

6.2.3.3.1 'Técnica' 185

6.3 Proposta preliminar de periodização para os estudos da relação do 185

PB com línguas africanas

$\begin{array}{ll}\text { Considerações Finais } & 188\end{array}$

Referências Bibliográficas 190 


\section{Introdução}

A presente dissertação tem os objetivos de mapear e analisar a produção linguística brasileira dedicada ao estudo das relações do Português do Brasil com línguas africanas (do século XIX ao XXI) e discutir a periodização disponível para a história dessa produção.

Para atingi-los, avaliamos a 'metodologia' e os tipos de 'fontes' empregados em dois conjuntos de textos: um conjunto constituído de obras publicadas entre o final do século XIX e a primeira metade do XX, outro, de estudos desenvolvidos a partir do último quartel do século $X X$.

As análises foram feitas com base no conceito de 'programa de investigação', proposto por Swiggers (1981a, 1991a, 2004).

No desenvolvimento dos estudos linguísticos no Brasil, há uma busca de determinação do papel do fator "África” nas análises das especificidades do Português Brasileiro (PB), seja em trabalhos que exploram mais diretamente essa correlação do PB com línguas africanas, seja em estudos interessados na história geral da língua.

Bonvini (2009:15-62) traça um panorama histórico dessa produção linguística no país, identificando, primeiramente, uma tendência a tratar a questão em termos de “influência” e, depois, uma aderência maior à hipótese de "crioulização”. O autor também destaca como característica marcante dessa 'tradição' de estudos deficiências em relação às 'fontes' e à 'metodologia'.

Quanto às 'fontes', segundo ele, o problema estaria em que as hipóteses de trabalho foram formuladas sem apoio em "fatos precisos, devidamente identificados e datados, suscetíveis de servir de 'provas' históricas” (2009: 21). O que teria prevalecido, para Bonvini, seria uma constante repetição de suposições feitas sem consulta a 'fontes' documentais precisas. Sabemos que as 'fontes' dessa natureza são muito escassas no Brasil, o que tornaria esse traço difícil de ser superado.

Quanto aos métodos, Bonvini afirma que os dados centram-se em aspectos léxico-semânticos ou morfossintáticos, recortes que ele julga insuficientes para lidar com o tema.

A partir das críticas feitas por Bonvini, caberia perguntar: 
a) Quais foram as 'fontes' (escassas) utilizadas nas pesquisas a respeito das relações entre línguas africanas e o português brasileiro?

b) Toda a produção sobre o tema, que tem sido tratado por diferentes gerações de estudiosos da linguagem no Brasil, desenvolveu-se com base nos mesmos princípios metodológicos criticados pelo autor? Houve guinadas metodológicas a serem nuançadas em tais estudos, que vêm dos anos 1800 até os nossos dias? De que tipos elas seriam?

c) De fato, houve mudanças de ênfase no tratamento da questão das línguas africanas, tal como afirma Bonvini, da hipótese da "influência” à da "crioulização"? Em que momento histórico?

Em vista desses questionamentos, decidimos investigar a história dos estudos da relação do $P B$ com línguas africanas a partir do conceito de 'programa de investigação’ proposto por Swiggers (1981a, 1991a, 2004). Esse conceito, em linhas bastante gerais, destina-se a distinguir ou agrupar pesquisas linguísticas de acordo com a maneira de o estudioso lidar com o 'objeto'. Estrutura-se a partir de três formantes: 'visão geral de linguagem', 'incidência' da análise (natureza dos dados privilegiados), 'técnica' (métodos empregados). Cremos que a avaliação desses aspectos nos permitiu ter uma visão de conjunto da produção ampla e diversificada que se construiu no país em torno do tema, desde o século XIX até a primeira década do século XXI.

Além desta Introdução, esta dissertação contém seis capítulos e algumas Considerações Finais.

No Capítulo1, Bases teóricas, discutimos nossos pressupostos em Historiografia Linguística, principalmente os que se referem à distinção estabelecida por Swiggers (2004 e outros) entre 'Epi-historiografia', 'Historiografia Descritiva' e 'Metahistoriografia', e ao conceito de 'programa de investigação', tal como formulado pelo mesmo autor. Apresentamos, também, uma discussão de revisões históricas disponíveis sobre o tema da relação entre o Português Brasileiro e línguas africanas.

Dedicamos o Capítulo 2 à Metodologia e materiais de pesquisa, apresentando as diretrizes da investigação em relação aos materiais, aos critérios e aos procedimentos de análise.

No Capítulo 3, apresentamos uma Bibliografia da produção brasileira dedicada à relação do PB com as línguas africanas no Brasil do século XIX ao XXI. Após apresentar esse conjunto de referências consideradas essenciais para o tratamento do 
tema, tecemos alguns breves comentários sobre essa produção, publicada entre os séculos XIX e XXI.

No Capítulo 4, denominado Obras inaugurais dos estudos do contato do PB com as línguas africanas: Macedo Soares (1942[1874-1890]), Mendonça (1935[1933]), Raimundo (1933) e Silva Neto (1950), apresentamos as análises dos textos que, no Brasil, podem ser tomados como fundadores dessa 'tradição' de estudos, a saber: Estudos lexicográficos do dialeto brasileiro (1942 [1874-1890]), de Antônio Joaquim de Macedo Soares [1838 - 1905]; A influência africana no Português do Brasil, de Renato Firmino Maia de Mendonça [1912 - 1990]; O elemento afro-negro na Língua Portuguesa (1933), de Jacques Raimundo Ferreira da Silva [?- 1960?], e Introdução ao estudo da língua portuguesa no Brasil (1950), de Serafim Pereira da Silva Neto (19171960).

No capítulo 5, denominado Algumas tendências contemporâneas nos estudos do contato do português brasileiro com as línguas africanas, percorremos, de forma panorâmica, quatro obras produzidas por pesquisadores atuais do tema da relação do PB com línguas africanas, a saber: Origens Do Português Brasileiro (2007), de Anthony Julius Naro e Maria Marta Pereira Scherre; Variedades Linguísticas Em Contato: Português Angolano, Português Brasileiro, Português Moçambicano (2008), de Margarida Maria Taddoni Petter; "African Languages and Brazilian Portuguese: A new approach", de Yeda Antonita Pessoa de Castro (2009) e O Português AfroBrasileiro (2009), organizado por Dante Eustachio Lucchesi Ramacciotti, Alan Norman Baxter e Ilza Maria de Oliveira Ribeiro. Procuramos abordar essas obras contemporâneas a partir dos mesmos parâmetros de análise utilizados no Capítulo 4 para tratar dos textos "clássicos" da área. Nessa apresentação de abordagens posteriores aos trabalhos de Mendonça (1933), Raimundo (1935[1933]), Macedo Soares (1942[1874-1890]) e Silva Neto (1950), procuramos destacar o possível diálogo entre esses textos mais atuais e aqueles textos fundadores, no que diz respeito à 'metodologia' e às 'fontes'. A partir dessa reflexão, identificamos algumas tendências ou caminhos dos estudos do contato do PB com as línguas africanas em território nacional.

No Capítulo 6, Resultados: Para uma historiografia dos estudos da relação do PB com línguas africanas, tendo em vista os objetivos desta pesquisa, procuramos correlacionar os resultados de nossas análises, apresentados nos capítulos 3, 4 e 5. Acreditamos ter chegado a três resultados principais: (1) uma bibliografia sobre o 
tema, e, a partir dela, uma análise panorâmica de tendências; (2) uma análise de textos representativos da 'tradição' em foco, baseada no conceito de 'programa de investigação' e (3) uma reunião de aspectos que permitem discutir uma periodização para a produção relativa às relações entre o $P B$ e as línguas africanas no contexto brasileiro.

Nas Considerações Finais, avaliamos, brevissimamente, os resultados de nossa investigação. 


\section{Capítulo 1}

\section{BASES TEÓRICAS}

Neste capítulo, pretendemos discutir e delimitar nossos pressupostos teóricos em Historiografia Linguística, principalmente no que se refere à distinção estabelecida em Swiggers (2004 e outros) entre 'Epi-historiografia', 'Historiografia Descritiva' e 'Meta-historiografia' e ao conceito de 'Programa de Investigação', tal como formulado pelo mesmo autor. Apresentamos também uma discussão sobre as revisões históricas existentes sobre o tema do contato do Português Brasileiro com as línguas africanas.

\section{1 'Historiografia', 'Epi-Historiografia' e 'Meta-Historiografia' dos estudos do PB com as línguas africanas}

Swiggers, em trabalhos em que discute o objeto e o campo da Historiografia Linguística, a define como: "[...] el estudio (sistemático y crítico) de la producción y evolución de ideas lingüísticas, propuestas por "actantes”, que están en interacción entre sí y con un contexto socio-cultural y político y que están en relación con su pasado científico y cultural" (Swiggers 2004: 105-106) ${ }^{1}$.

A Historiografia Linguística, para Swiggers, deve se constituir como uma disciplina científica, isto é, com padrões metodológicos e epistemológicos bem definidos. Ele defende, para o historiógrafo, um "exame sistemático e crítico que reflita a respeito de seus próprios resultados descritivos" (Swiggers 2004: 105-106). Nesse sentido, ele propõe que o historiógrafo distinga, em sua disciplina, três níveis de organização do trabalho com as suas respectivas tarefas: 'Epi-historiografia', 'Metahistoriografia' e a 'Historiografia descritiva'.

Tarefas de natureza Epi-Historiográfica têm papel fundamental no campo de estudos da Historiografia Linguística, principalmente quando se pretende descrever e

\footnotetext{
1 “[...] o estudo (sistemático e crítico) da produção e evolução das ideias linguísticas, propostas por "agentes", que estão em interação entre si e com o contexto social e político e que estão em relação com seu passado cientifico e cultural" (tradução nossa).
} 
interpretar a produção e difusão do conhecimento linguístico no tempo e em contexto trabalho que exige a ancoragem no tratamento minucioso de fontes.

A 'Epi-Historiografia' tem como função servir de apoio à Historiografia, por meio da "[...] edición o de traducción de textos, de corrección de errores, en publicación de fuentes primárias y también las actividades de documentación 'prosopográfica' (biográfica), heurística (información sobre archivos, ejemplares de obras, etc.) y bibliográfica (incluyendo bibliografias de vários tipos: sobre autores y textos, sobre temas, sobre conceptos)" (Swiggers 2004: 116)². A esse ramo lateral da Historiografia também cabe realizar a "[...] história dos "agentes" (pesquisadores individuais, ou grupos de pesquisadores de uma língua), e "materiais" produzidos (papiros, manuscritos, livros, artigos, textos eletrônicos, etc.) [...]” (Swiggers 2011: 5). Essa primeira etapa, que consiste na busca, tratamento e disponibilização de fontes é absolutamente necessária e imprescindível para a realização das atividades de descrição e reflexão que chamaríamos de mais propriamente historiográficas.

É possível que o pesquisador da Historiografia Linguística se dedique exclusivamente à realização dessas tarefas epi-historiográficas ou também às de natureza meta-historiográficas e historiográficas. É possível, também, que a historiografia conte com a contribuição de filólogos, tradutores, bibliotecários e profissionais da área de informação, historiadores (da língua e da sociedade), filósofos, entre outros, no desempenho dos diferentes fazeres epi-historiográficos. O fato é que não é possível desenvolver a atividade historiográfica, de caráter descritivo e interpretativo, sem a base segura oferecida pelo adequado tratamento das 'fontes' de dados.

A 'Meta-Historiografia', por sua vez, tem por objeto refletir sobre as práticas e os produtos historiográficos, seus princípios e métodos. Trata-se, portanto, de uma atividade epistemológica. Segundo Swiggers (2011: 5), a 'Meta-Historiografia' tem três dimensões:

a) a 'construtiva', que "[...] almeja o desenvolvimento de modelos para a narrativa da historiografia linguística da reflexão e descrição linguísticas, e a articulação de um modelo coerente, abrangente e preciso";

\footnotetext{
2 “[...] edição ou tradução de textos, correção de erros, publicação de fontes primárias e também das atividades de documentação "prosopográfica" (biográfica), heurística (informação sobre arquivos, exemplares de obras, etc.) e bibliográfica (incluindo bibliografias de vários tipos: sobre autores e textos, sobre temas, sobre conceitos)" (tradução nossa).
} 
b) a 'crítica' dedicada a '[...] avaliar, no nível da documentação empírica e no nível dos princípios metodológicos e epistemológicos, os produtos resultantes da prática historiográfica”, e

c) a 'contemplativa', que "[...] diz respeito à definição do objeto e do status da historiografia linguística, aos fundamentos e à justificativa de formatos e perfis historiográficos, e a problemas 'transcendentes', tais como o conceito de 'fato histórico', ou a noção de 'verdade' na história da linguística”.

Todo historiógrafo, ainda que não formalize suas reflexões metahistoriográficas, as revela em suas escolhas, nas diferentes formas de aproximação com o seu objeto de estudo, nos modos de descrevê-lo e explicá-lo. Elas se fazem presentes na perspectiva teórica e na metodologia adotadas pelo pesquisador (Swiggers 2009: 68). No entanto, há um conjunto de historiógrafos especialmente interessados nesse tipo de atividade, como o próprio Swiggers, Koerner e outros.

A tarefa descritivo-explicativa (ou 'Historiografia Descritiva') das manifestações linguísticas do passado requer a contribuição da 'Epi-Historiografia' e da 'MetaHistoriografia' para ser bem executada.

A 'Historiografia Descritiva' é a descrição e análise de um 'conteúdo significativo' (Swiggers 2004: 15), no nosso caso, os estudos sobre o contato do PB com as línguas africanas no Brasil. A atividade de descrição requer uma documentação (estabelecida por uma 'Epi-Historiografia') e um trabalho de análise da documentação guiado por princípios teóricos e metodológicos claros (fixados por uma determinada 'Meta-Historiografia'). Assim, a Historiografia Linguística é “[...] a narrativa descritivoexplicativa da reflexão e descrição linguística no passado ("passado" que se estende até o presente do historiógrafo) [...]” (Swiggers 2011: 5).

Nossa investigação teve tarefas 'epi-historiográficas' importantes, uma vez que pretendeu oferecer uma reconstrução sistematizada da produção sobre o contato entre o $\mathrm{PB}$ e as línguas africanas aos estudiosos do tema ou interessados em linguística, o que implicou na busca e tratamento de fontes. Essas tarefas que consistiram na sistematização de documentação (bio)bibliográfica se revelaram especialmente necessárias diante da ausência de crônicas ou revisões históricas de maior fôlego sobre o tema. Mesmo a respeito da produção linguística brasileira como um todo, Altman 
(2004) afirma que trabalhos que reúnam a produção linguística brasileira de modo sistemático são poucos ${ }^{3}$, embora sejam bastante desejáveis (Altman 2004: 29).

Ao lado das tarefas epi-historiográficas relativas à documentação (bio)bibliográfica, ao tratamento de fontes e dados 'brutos', esta investigação também pretendeu oferecer uma contribuição à Historiografia Descritiva do tema, ancorando-se em princípios e métodos específicos (em uma certa proposta meta-historiográfica). Cientes, nesse nível meta-historiográfico, de que, ao analisar a produção linguística, podíamos tentar ir além de rótulos mais aparentes e que seria desejável estabelecer aproximações de acordo com a natureza interna dos trabalhos, operamos, fundamentalmente, com o conceito de 'programa de investigação' (Swiggers 1981a, 1991a, 2004), com o objetivo de melhor compreender algumas das características dessa produção, heterogênea e quantitativamente expressiva (veja Capítulo 3).

\subsection{Revisitando revisões históricas}

Com efeito, ainda que os estudos sobre o contato do português brasileiro ${ }^{4}$ com as línguas africanas constituam, desde o século XIX até o XXI, uma relevante 'tradição' de pesquisa (Pinto 1978; 1981, por exemplo), sua história ainda não foi estabelecida. Essa linha de estudos se mantém profícua, ainda que apresente momentos de descontinuidade ou de menor investimento por parte da comunidade acadêmica brasileira; contribuir para o estabelecimento de sua história é nosso objetivo 'descritivo'.

Como dissemos, essa é ainda uma lacuna em nossa historiografia, apesar de o tema ter sido explorado com constância no território nacional, principalmente nos estudos acerca das especificidades do PB frente às demais variedades do português.

A constante produção sobre o tema - que mapeamos - parece se avolumar e ficar em evidência mais recentemente entre grupos acadêmicos dispersos por diferentes instituições de ensino que têm produzido expressiva quantidade de trabalhos ${ }^{5}$. De fato,

\footnotetext{
${ }^{3}$ Altman (2004: 30) lista os seguintes trabalhos: Pinto (1978, 1981); Dietrich (1980), Baranov (1990) e Marcuschi (1992).

${ }^{4}$ Doravante PB.

${ }^{5}$ Característica da pesquisa acadêmica nos tempos atuais, que talvez se relacione a exigências de alta produtividade dos pesquisadores (cf. Chauí 2014). Uma breve discussão das reflexões de Chauí sobre o tema é apresentada no Capítulo 5 desta dissertação.
} 
há, hoje, um número significativo de publicações que, em alguma medida, tocam no tema, a partir de diferentes enfoques ${ }^{6}$.

É notável também o número de pesquisadores que, inseridos em outras subáreas de pesquisa em Linguística, se voltam para esse tema nos dias de hoje, ou que em algum momento de suas trajetórias acadêmicas tenham opinado nesse debate.

Entretanto, a antiguidade e o volume dos estudos sobre o tema não implica consenso entre os pesquisadores. O impacto em termos linguísticos do tráfico de negros escravizados pelos colonizadores europeus entre os séculos XVI e XIX no Brasil é questão controversa, talvez em função da escassa documentação disponível para sustentar discussões mais consistentes.

Do ponto de vista historiográfico, sabemos que existem poucos trabalhos que se dedicaram exclusivamente a mapear e analisar a produção linguística brasileira sobre o contato do PB com línguas africanas ${ }^{7}$.

Emílio Bonvini (2009) ${ }^{8}$, em sua retrospectiva, propõe que no contexto brasileiro, a história do tratamento deste tema poderia ser dividida em dois momentos que correspondem a dois tipos de abordagem do fenômeno: "o primeiro é caracterizado pela afirmação da influência africana no PB, e o segundo, pela hipótese da crioulização do português do Brasil com as línguas africanas” (Bonvini 2009:16).

Para essa proposta de duas tendências principais ao longo da história, ainda que esteja em jogo um rompimento de base epistemológica, os aspectos contextuais ganham relevância, eles é que funcionam como parâmetro essencial para separar a produção considerada em duas vertentes, já que cada uma delas teria preponderado em momentos históricos distintos:

\footnotetext{
${ }^{6}$ Para uma visão mais ampla da continuidade histórica do tratamento do tema e da diversidade de abordagens, ver, no Capítulo 3, nosso mapeamento da produção brasileira sobre o contato do PB com as línguas africanas.

${ }^{7}$ Refiro-me, aqui, aos interesses exclusivamente direcionados a essa correlação. Sabemos que há revisões bastante relevantes acerca do tratamento do PB, como o monumental trabalho de Pinto (1978, 1981). Sobre as revisões particularmente interessadas na presença africana, nota-se a escassez mencionada, ainda que comumente os pesquisadores se dediquem a desenhar, minimamente, o passado de sua disciplina no início de seus trabalhos, o que faz que sejam relativamente comuns as breves crônicas ou referências assistemáticas, por exemplo, nas introduções de teses e dissertações.

${ }^{8}$ BONVINI, Emilio. 2009. Línguas africanas e o português falado no Brasil. In: FIORIN, José Luiz; PETTER, Margarida (Org.). África no Brasil: a formação da língua portuguesa. Contexto: São Paulo, p. 15-62. Estudo reproduzido, parcialmente, em BONVINI, Emilio; PETTER, Margarida. 1998. Portugais $\mathrm{du}$ Brésil et langues africaines. Langages. Paris, n. 130, p. 68-83 e em PETTER, Margarida. 1998. A presença de línguas africanas no português do Brasil. Estudos Lingüísticos (São Paulo), São José do Rio Preto, v. XXVII, p. 777-783.
} 
a) a vertente que sustenta a hipótese da 'influência', preponderante ao longo dos anos 1930, teria buscado defender as especificidades do PB frente às características do português europeu. Haveria uma ideologia nacionalista disseminada por diferentes circuitos intelectuais, que também permearia os estudos linguísticos: o Brasil independente buscava seu lugar em relação à antiga metrópole. Bonvini (2009) elenca como textos representativos dessa vertente Raimundo (1933) e Mendonça (1935[1933]). A questão do contato entre o PB e as línguas africanas foi retomada também em termos de "influência" por Castro (1976, 1980), indicando que, embora descontínua, tal vertente se mostraria persistente ao longo da história.

b) a vertente que discute a hipótese da 'crioulização' teria emergido nos trabalhos posteriores à década de 1930. Em um contexto em que se dava início à formação e à atuação mais especializada dos estudiosos da língua, com a fundação de faculdades de Letras, explicações de caráter mais interno teriam ganhado destaque, em oposição à mobilização de dados extralinguísticos, característica da fase anterior. Neste sentido, autores como Serafim Pereira da Silva Neto (1950), Gladstone Chaves de Melo (1946), Sílvio Edmundo Elia (1940) teriam tratado do contato em termos de crioulização, a partir da ideia de 'unidade na diversidade', isto é, teriam procurado salientar os elementos comuns nas variedades brasileira e europeia em detrimento das peculiaridades de cada uma, de modo que o contributo índio ou negro teria sido pouco impactante. Silva Neto (1950), nessa medida, admite a existência de “[...] falares africanos episódicos, crioulos e semicroulos, que eram apenas uma deformação e uma simplificação do português [...]" (Silva Neto 1950: 18) e cujos traços permaneceriam nos dialetos rurais. Melo (1946) afirma que o contato acelerou as tendências do sistema da língua portuguesa, influenciado pelo conceito de 'deriva' de Sapir. Sílvio Elia (1940, 1979) distingue crioulos e semicrioulos, afirmando que no Brasil teriam existido somente os segundos (estágio anterior aos crioulos, em que haveria uma simplificação da língua portuguesa). Mais recentemente, os pesquisadores estrangeiros Gregory Guy (1981, 1989), John Holm (1987) e Alan Baxter, em 1987/1988, retomaram o debate acerca da crioulização. Holm, por exemplo, considera o PB como um 
semicrioulo a partir da comparação com crioulos de base ibérica, dados sóciohistóricos e demográficos.

Em oposição às duas perspectivas apresentadas, isto é, a hipótese da 'influência' e a da 'crioulização', Bonvini (2009) destaca também os trabalhos de Anthony Naro e Scherre (1973a, 1978) e de Fernando Tarallo (1993[1986]). Esses autores argumentaram contra a hipótese da crioulização (veja, no Capítulo 5, uma descrição da proposta de Naro \& Scherre).

Ao analisar a condução desses estudos, Bonvini critica alguns aspectos que teriam prevalecido em ambas as vertentes, dentre eles aspectos que dizem respeito à natureza $\mathrm{e}$ ao tratamento das 'fontes' de dados linguísticos e à metodologia de estudos empregada.

Com relação à natureza e ao tratamento das 'fontes', o africanista afirma que as hipóteses de trabalho foram formuladas sem apoio em "[...] fatos precisos, devidamente identificados e datados, suscetíveis de servir de "provas" históricas [...]" (Bonvini 2009: 21). O que teria prevalecido, segundo Bonvini, seria uma constante repetição de suposições feitas sem consulta a 'fontes' documentais precisas.

A crítica referente à metodologia empregada diz respeito à seleção preponderante de dados de natureza léxico-semântica ou morfossintática, recorte que ele julga inadequado para lidar quer com o conceito de 'influência', quer com o de 'crioulização'.

Outro aspecto criticado diz respeito ao 'espaço' linguístico considerado. As hipóteses formuladas nesses estudos teriam tratado do PB desconectado de outras variedades, como as faladas na África, assim como teriam desprezado os contatos anteriores e paralelos entre elas. As relações levadas em consideração teriam sido as que envolveram o PB e o português europeu ${ }^{9}$, apenas. Os resultados, assim, teriam sido prejudicados também por essa falta de visão de conjunto.

Tendo em vista a produção brasileira sobre o tema em sua totalidade, Bonvini conclui que:

Esse debate, que já conta com mais de um século, está longe de acabar. As formulações sucessivamente propostas, uma depois das outras, modificadas ou rejeitadas, fazem transparecer o caráter claramente indeciso do caminho, assim como a incerteza quanto aos resultados. Tudo não parece ultrapassar o estágio de hipóteses. Impõe-se, por conseguinte, a necessidade de um prosseguimento da pesquisa, desde que ela seja conduzida por novas perspectivas teóricas e, sobretudo, por dados suplementares devidamente estabelecidos (Bonvini 2009: 21).

\footnotetext{
${ }^{9}$ Doravante PE.
} 
Lucchesi $(2012,2008 b)^{10}$, em sua reflexão sobre o tratamento do tema no Brasil, sustenta que razões ideológicas e teóricas teriam motivado a opção, de estudiosos brasileiros, por negar ou minimizar o impacto do contato do PB com línguas africanas. Segundo ele, Silva Neto, Chaves de Melo e Elia, filólogos brasileiros, além de Scherre \& Naro teriam operado em uma tradição de explicação imanentista. Ou seja, as interpretações que se apoiariam em elementos extralinguísticos, como o contato entre populações, estariam fora do escopo desse tratamento que privilegia as questões internas ao sistema linguístico.

Para Lucchesi, o impacto das teorias reconhecidas como estruturalistas, notadamente relacionadas às figuras de Saussure e Sapir, teria colaborado para a negação (ou desprivilégio) da hipótese do contato das línguas africanas com o português brasileiro:

[...] a forte tradição imanentista que se estabeleceu na Linguística Moderna desde que Saussure decretou que a língua é uma estrutura que se move em função de sua lógica interna tem-se renovado, muitas vezes, de forma surpreendente, como no caso dos sociolinguistas Anthony Naro e Marta Scherre (1993 e 2007), que, resgatando o conceito sapiriano de deriva linguística, têm refutado qualquer proeminência do contato entre línguas na formação do português brasileiro, afirmando que o contato linguístico teria apenas acelerado tendências já presentes na evolução da língua portuguesa desde suas origens latinas (Lucchesi 2012: 47).

Em associação a essas opções teóricas, Lucchesi acrescenta também razões ideológicas - como o sentimento de purismo linguístico, marcado pela submissão à exmetrópole, e a ideia de superioridade cultural europeia - como explicações para negação (ou minimização) da importância do contato entre línguas.

No plano das representações científicas, a força da visão disseminada na ciência da linguagem a partir da perspectiva teórica do estruturalismo linguístico, que via a história da língua como o desenvolvimento autônomo de sua estrutura interna, conjugada à visão discricionária de uma superioridade cultural do colonizador europeu, fez com que muitos linguistas e filólogos tentassem minimizar ou mesmo refutar a participação de africanos e crioulos na formação da língua nacional.(Lucchesi 2008b: 176).

No caso de Silva Neto (1950), Lucchesi ainda destaca a contradição do autor, que teria identificado alguns aspectos do $\mathrm{PB}$, relacionando-os ao contato linguístico, além de ter apresentado o conceito de semicrioulo; mas, ainda assim, ao final, Silva

\footnotetext{
${ }^{10}$ Lucchesi $(2012 ; 2008$ b) propõe que a transmissão linguística irregular do tipo leve pode explicar a realidade linguística brasileira. Segundo ele, o contato do PB com as línguas africanas não foi suficiente para gerar línguas crioulas, mas causou um amplo processo de erosão morfológica, principalmente nas variedades populares do $\mathrm{PB}$.
} 
Neto teria renegado o contributo africano ao reafirmar a hipótese da unidade na diversidade.

A localização de fontes confiáveis de dados históricos também é destacada por Lucchesi como uma dificuldade para a realização do trabalho científico:

\begin{abstract}
Porém, muita pesquisa histórica ainda precisa ser feita, e um dos maiores desafios para aqueles que se ocupam da historiografia linguística do Brasil é precisar as situações sociolinguísticas em que se deu o contato entre línguas para se poder determinar com uma base empírica satisfatória que mudanças tais situações promoveram na estrutura da língua nacional (Lucchesi 2008b: 165-6).
\end{abstract}

De modo semelhante a Bonvini, Lucchesi aponta estudiosos brasileiros que teriam considerado o impacto das línguas africanas com o PB em termos de crioulização (a favor ou contra). Ambos os autores identificam questões ideológicas que motivaram os estudiosos em questão (Silva Neto, Chaves de Melo e Elia) a relativizar a importância do contato. Lucchesi identifica as mesmas questões nos trabalhos de Naro e Scherre, aspecto não mencionado por Bonvini ao tratar desses autores.

Outro texto que busca discutir a história dos estudos sobre o tema no Brasil é "Situações linguageiras favorecedoras da difusão do português no Brasil: a África na Historiografia Linguística Brasileira”, de André P. Bueno e Ana Stela Cunha (2004).

Os autores discutem a escassez de dados linguísticos registrados na modalidade escrita; estariam eles restritos a poucos textos de cronistas, viajantes, historiadores e missionários, tais como Serafim Leite (1938), Frei Vicente de Salvador (1627), Saint Hilaire (1820). Em vista disso, propõem a utilização de dados da história oral e da etnomusicologia para a reconstrução da história dos contatos. Ambas as estratégias priorizam, segundo eles, “[...] a língua em uso, em situações e localizações geográficas específicas [...]” (Bueno e Cunha 2004: 38).

Segundo Bueno e Cunha, a falta de documentação acentua-se no domínio da linguagem, em comparação com a História (social e econômica) e a Antropologia, áreas em que foi possível mapear, minimamente, a presença de negros africanos escravizados no Brasil ${ }^{11}$.

Do século XIX ao XX, os autores verificam o registro de palavras de origem africana nos estudos sobre o contato, associado à busca de uma língua nacional, quadro

\footnotetext{
${ }^{11}$ Os autores lembram que a destruição de documentos históricos ordenada pelo Ministério da Fazenda, em medida oficial 29 em 13 de maio de 1891, privou os historiadores de dados substanciais sobre o universo negro-africano no Brasil.
} 
de observação que teria mudado com os trabalhos de Mendonça (1935[1933]) e, posteriormente, com os de Pessoa de Castro (1968, 1976, 1980, 1998), bem como com os trabalhos de campo de Vogt \& Frey (1996), Queiroz (1998), Lucchesi (2001) e Cunha (2003).

Outro artigo que também tenta oferecer um panorama histórico sobre o tratamento do tema no país é "Remanescentes culturais africanos no Brasil" (2002), em que Sônia Queiroz trata dos estudos sobre o negro no país realizados a partir do século XIX, destacando as publicações sobre as línguas e a cultura; os congressos realizados, principalmente os da década de 30; os centros de estudos formados, criados a partir da segunda metade do século XX; e os núcleos de resistência cultural africana do final do século XX.

Queiroz avalia os estudos no campo linguístico como bastante precários: em sua maioria, teriam sido dedicados à questão da influência das línguas africanas no português brasileiro. Segundo a autora, estudos em termos de "influência" colocariam aspectos constitutivos da civilização brasileira em segundo plano:

\begin{abstract}
Assim, é comum entre nós a mentalidade assimilacionista, que privilegia a tradição europeia e relega nossos índios e negros ao plano das simples influências, como se nossa cultura os precedesse, o que, levado às últimas consequências, corresponde a dizer que a civilização brasileira é anterior ao próprio descobrimento do Brasil! (Queiroz 2002: 48).
\end{abstract}

Esses trabalhos teriam surgido somente a partir do século XIX; até então, pouco havia sido escrito sobre o negro no Brasil. Nesse sentido, Nina Rodrigues é considerado o precursor dos estudos sobre o tema por ter uma abordagem científica em Os Africanos no Brasil publicado, postumamente, em 1933.

Queiroz afirma que há um apagamento na produção desses estudos, com exceção da figura de Arthur Ramos, que são retomados somente na década de 1930 com a obra Casa Grande e Senzala (1934), de Gilberto Freire. Ainda na década de 30:

Realizam-se dois congressos afro-brasileiros, o primeiro em Recife, em 1934, e o segundo na Bahia, em 1937. Destacam-se, então, numerosos pesquisadores, entre os quais os brasileiros Edison Carneiro, Renato Mendonça, Dante Laytano, Mário de Andrade, Aidano do Couto Ferraz e os estrangeiros Donald Pierson, Melville J. Herkovits, Roger Bastide e Pierre Verger (Queiroz 2002: 50). 
Posteriormente, os estudos teriam voltado seu interesse, principalmente, para religiões afro-brasileiras (Roger Bastide, Pierre Verger e Yvonne A. Velho) e para as relações raciais (Florestan Fernandes, Oracy Nogueira e Otávio Ianni).

Em 1959, é fundado o Centro de Estudos Afro-Orientais (CEAO), na Universidade Federal da Bahia, responsável pela publicação da Revista Afro-Ásia (1965). Em seguida, criam-se o Centro de Estudos Africanos (CEA), em 1965, na Universidade de São Paulo, e o Centro de Estudos Afro-asiáticos da Universidade Cândido Mendes, no Rio de Janeiro, que edita a Revista de Estudos Afro-asiáticos. Em 1981, a Universidade Federal de Minas Gerais promove o I Encontro Nacional de Centros de Estudos Afro-Brasileiros.

Na década de 70, Queiroz destaca a produção intelectual de Yeda Pessoa de Castro. Nessa época, Queiroz também verifica o tratamento da questão da influência africana em obras de caráter mais genérico sobre a língua portuguesa e a cultura.

No que se refere, especificamente, aos estudos linguísticos, Queiroz reitera a deficiência do campo, que ainda não teria evidenciado, devidamente, a importância do negro na sociedade brasileira:

\begin{abstract}
No que diz respeito aos estudos linguísticos, nossa situação é ainda mais precária, embora eles tenham recebido certo impulso na década de $30-$ quando se publicam os livros considerados clássicos no assunto. É importante observar que a grande maioria desses trabalhos se ocupa da influência das línguas africanas no português brasileiro, na tentativa de definir até que ponto os negros foram os responsáveis pela diferenciação linguística que se verifica entre Portugal e Brasil (Queiroz 2002: 50)
\end{abstract}

Outra linha de estudos concentra-se na busca dos falares africanos no Brasil. Segundo Queiroz, ela teria pouca ou quase nenhuma atenção dos estudiosos. Dentre os que se dedicam (ou se dedicaram) a essa questão, ela aponta, no século XVIII, Antônio da Costa Peixoto; no XIX, Nina Rodrigues; no XX, Rodolfo Garcia, João Dornas Filho, Aires da Mata Machado Filho, Carlos Alberto Vogt, Peter Fry, Maurizio Gnerre e Mário Roberto Zágar.

Só recentemente, no final do século $\mathrm{XX}$, políticas públicas de fomento à diversidade cultural e étnica, ao lado do interesse de pesquisadores, teriam recolocado o tema da presença do negro no Brasil em destaque. Ela finaliza:

O que se pode perceber é que o investimento na pesquisa sobre os remanescentes culturais africanos no Brasil acaba por delinear com maior clareza nosso ainda grande desconhecimento sobre a contribuição afro-negra à formação da cultura brasileira e, ao mesmo tempo, a enorme força e alcance dessa contribuição. Eu diria, portanto, que, neste campo de estudos, estamos 
ainda começando. Mais do que nunca, vivemos um momento de chamada à pesquisa sobre o tema fascinante da pluralidade cultural no Brasil (Queiroz 2002: 56)

Diante da escassez de trabalhos que estabeleçam a história do tratamento do contato entre o PB e as línguas africanas no Brasil, esta dissertação foi elaborada em torno dos seguintes objetivos:

Mapear e analisar a produção que se dedicou a investigar as relações entre o português brasileiro e as línguas africanas no Brasil, e

Discutir a periodização existente para história dessa produção, a partir da análise da metodologia dos textos e das 'fontes' utilizadas; análise feita com base no conceito de "programa de investigação" proposto por Swiggers (1981a, 1991a, 2004).

Pareceu-nos necessário procurar discutir uma periodização para essa produção, já que as diferentes crônicas históricas tendem a apresentá-la distribuída apenas em conformidade com a história social (décadas, séculos, períodos políticos), sem que esse agrupamento reflita também aspectos relativos à natureza dos trabalhos de descrição linguística (aspectos internos) realizados.

\subsection{Princípios gerais da análise}

Julgamos que é possível ressaltar os aspectos relativos à natureza dos trabalhos valendo-nos do conceito de "programa de investigação". Segundo Swiggers, um 'programa de investigação':

[...] is a complex cognitive system which makes possible some particular operations and results, while excluding other possibilities. One program subsumes several theories which despite technical and terminological differences, have the same concept of how the object of the discipline must be investigated. Both object and method are defined intra-theoretically, but the unity of a program resides the similar conceptions of how a certain method must "deal with" the object of a particular discipline (Swiggers 1981a: 12, grifos do autor $)^{12}$

12 “[...] é um sistema cognitivo complexo que torna possíveis algumas operações e resultados particulares enquanto exclui outras possibilidades. Um programa subordina/classifica algumas teorias que, apesar das suas diferenças técnicas e terminológicas, têm o mesmo conceito de como o objeto da disciplina deve ser investigado. Ambos, objeto e método, são definidos intra-teoricamente, mas a unidade do programa reside 
Ou seja, pode-se distinguir e agrupar pesquisas linguísticas, ainda que sejam realizadas de acordo com diferentes teorias, uma vez que o conceito de 'programa de investigação' revela a maneira mais ampla de os estudiosos lidarem com um mesmo objeto de investigação (neste caso, o contato entre PB e línguas africanas).

O conceito de 'programa de investigação' se contrapõe a outros conceitos operatórios na Historiografia Linguística, tais como os que estão por trás dos termos 'escola' ou 'tradição', que parecem reforçar as ideias de linearidade e de continuidade históricas. O conceito de 'programa de investigação' permite descrever a história da disciplina para além da perspectiva da acumulação de conhecimentos, permitindo que se enxerguem nuances de continuidade e descontinuidade mesmo entre propostas mais afastadas no eixo temporal.

Trata-se, também, de uma alternativa aos conceitos de 'paradigma', 'comunidade científica' e 'revolução', de Thomas Kuhn ${ }^{13}$ (1922-1966). Na obra $A$ Estrutura das Revoluções Científicas (2007[1962]), Kuhn defende que o desenvolvimento das ciências não se dá por meio da acumulação crescente de conhecimentos, mas sim por uma série de episódios desintegradores dos valores em circulação em um campo de conhecimento. Nessa perspectiva, as 'revoluções científicas' (as rupturas, as descontinuidades) moveriam a ciência (Kuhn 2007[1962]: 24-25).

Swiggers, como outros meta-historiógrafos, discute a aplicabilidade do modelo kuhniano em Linguística. Segundo ele, em cada contexto considerado, é difícil distinguir uma 'escola' ou 'tendência paradigmática' de uma 'não-paradigmática' nessa disciplina. Inclusive, a noção de 'comunidade científica' não é aplicável em determinados contextos, como o período greco-romano ou a Idade Média.

Swiggers destaca que nas ciências humanas é impossível separar os aspectos internos e externos na dinâmica de seu desenvolvimento, tal dificuldade cria um problema metodológico em historiografia (Swiggers 1991a: 2713). Para descrever a evolução do pensamento linguístico, é necessário caracterizar os conjuntos teóricos que são o tópico e o motor da evolução.

nas concepções similares de como determinado método deve lidar com o objeto de uma disciplina particular" (tradução nossa).

${ }^{13}$ Físico norte-americano e historiador da ciência. 
Nesse sentido, o conceito de 'programa de investigação' permite agrupar teorias, às vezes dispersas no percurso histórico, sempre que elas tenham a mesma percepção da "maneira certa de se fazer linguística" (Swiggers 1981:15). Ao mesmo tempo, o autor reconhece como pertencentes a diferentes 'programas' perspectivas epistemológicas simultâneas no tempo.

Swiggers recomenda que o conceito de 'programa' não tenha uma interpretação radical. No entanto: "[...] the variegated picture which the history of linguistics offers us, must be understood, and this seems impossible without a (reductionist) model for the history writing of linguistics" (Swiggers 1981a: 16, grifo do autor) ${ }^{14}$.

Ou seja, o conceito de 'programa de investigação' pode auxiliar no melhor entendimento do desenvolvimento da Linguística, pois abrange a sua diversidade teórica e de interesses:

[...] It seems that programs are responsible for the uniformization of certain types of research, and for imposing specific restrictions on work carried out within a particular program. Programs have an irreversible aspect: once they have been introduced, they support certains pattens of action, while eliminating others. This is probably due to the fact that a program offers the scientist a particular language (which, in the case of linguistic theories, is a meta-language for 'scientific activity'[...] (Swiggers 1981a: 14) ${ }^{15}$

A diversidade de pontos de vista revela os conjuntos, as analogias e as divergências presentes nos contextos sociais, políticos, culturais e institucionais em que estão inseridas (Swiggers 1991a: 2713). Este jogo de interações entre teorias e contextos move a ciência, afirma Swiggers; esse movimento não estaria na alternância 'paradigma' e 'revolução', mas se constituiria em termos de 'continuidade' e 'descontinuidade' de determinados interesses (ou 'programas de investigação') que podem coexistir e persistir ao longo da história (Swiggers 1991a: 2713).

Swiggers (1991a, 2004) distingue 'programas de investigação' na história da linguística a partir de três parâmetros: 'visão de língua' ("ponto de vista global”), ‘incidência de análise' (“contexto específico de inserção dos dados”) e 'técnica' ("a

\footnotetext{
14 “[...] o quadro variado que a história da linguística nos oferece, deve ser entendido, e isso parece ser impossível sem um modelo (reducionista) para a escrita da história da linguística" (tradução nossa, grifos do autor).

15 “....] Parece que os programas são responsáveis pela uniformização de certos tipos de pesquisa e pela imposição de restrições específicas sobre o trabalho realizado dentro de um programa particular. Programas têm um aspecto irreversível: uma vez que eles foram introduzidos, eles suportam certos padrões de ação, enquanto eliminam outras possibilidades. Isto é provavelmente devido ao fato de que um programa oferece ao cientista uma linguagem particular (que, no caso das teorias linguísticas, é a metalinguagem para a 'atividade científica') [...]” (tradução nossa).
} 
'sintaxe' descritiva do programa”) (Swiggers 1991a: 2714), parâmetros que também empregamos em nossa análise com o objetivo de 'classificar' internamente a produção que selecionarmos.

O autor entende que:

a) 'Visão de língua' diz respeito à maneira como a linguagem (ou as línguas, ou os grupos de línguas) é considerada e aos modos de conceber as relações entre língua e realidade, língua e literatura, língua e sociedade, língua e cultura; também se inclui aqui a concepção do campo de investigação ou da disciplina.

b) 'Incidência de análise' diz respeito às formas linguísticas (por exemplo, morfema, item lexical, frase, conteúdo) privilegiadas e à natureza e função preferencialmente atribuídas a essas formas.

c) 'Técnica' corresponde ao conjunto de princípios e métodos descritivos adotados.

Segundo esses parâmetros, Swiggers delimita, ao longo da história dos estudos da linguagem no Ocidente, quatro programas fundamentais de investigação: o 'programa de correspondência', o 'programa descritivista', o 'programa sociocultural' e o ‘programa de projeção’ definidos como segue (Swiggers 1991a):

a) 'Programa de correspondência': considera a língua na articulação com o pensamento. Tem como 'visão' o estabelecimento de uma correlação entre língua - pensamento - realidade. 'Incide' sobre as relações entre estruturas morfossintáticas e conteúdos e os processos mentais, e tem como 'técnica' a semantização de estruturas gramaticais (estabelecimento de classes lógicosemânticas e processos mentais e regras gramaticais). Teriam operado nesse programa Platão, Aristóteles, Varrão, os Modistas, os gramáticos-filósofos dos século XVII e XVIII, Gustavo Guillaume, Humboldt e Noam Chomsky (e seus seguidores);

b) 'Programa descritivista': tem como fundamento a ideia de que as formas linguísticas constituem um campo autônomo e autossuficiente. Nele, há duas orientações mais gerais: a formalista (voltada para a taxionomia e estruturação 
das formas) e a funcionalista (que anexa à estrutura formal um conjunto de funções comunicativas). Tem como 'visão' a descrição das línguas como objeto autônomo e 'incide' sobre a forma e função de fenômenos observáveis, por vezes comparando-os em diversas línguas. Para tanto, utiliza as 'técnicas' de determinação de contextos, segmentação, comutação, estudo das relações de proporcionalidade entre os elementos e estabelecimento de relação entre as formas linguísticas e funções comunicativas. De longa tradição, Swiggers cita como exemplos deste programa: os gramáticos sânscritos, alexandrinos, romanos e carolíngios, além dos da Renascença, bem como os comparativistas e linguistas estruturalistas como Bloomfield e Martinet.

c) 'Programa sociocultural': é aquele em que a língua é vista como um dado cultural e social. Fundamenta-se na 'visão' de língua como objeto sujeito a variação e variabilidade, geralmente atreladas a fatores externos. 'Incide' sobre a determinação dos usos linguísticos, a competência comunicativa, a variação sociolinguística e a expressão de uma cultura através da língua. Tem como 'técnica' a inserção de fatos linguísticos em uma análise das sociedades ou das culturas, bem como em uma teoria da estratificação social ou da evolução social ou cultural. São exemplos os trabalhos de Dante, Max Müller, Boas, Labov, Dell Hymes e Whorf.

d) 'Programa de projeção': é resultado da transferência de um modelo elaborado na lógica formal à descrição de línguas naturais; a 'visão' é a de que certos fragmentos das línguas correspondem a estruturas lógicas. 'Incide' sobre subsistemas gramaticais particulares, tais como os de tempos e modos verbais, de determinação nominal, de quantificação, entre outros. Tem como 'técnica' a tradução de estruturas linguísticas em linguagem formalizada. Operaram segundo as diretrizes deste programa, por exemplo, Saumjan, Montague e Hintikka.

Investigamos a produção brasileira sobre o contato do PB com as línguas africanas a partir dessas categorias ('visão de língua', 'incidência de análise' e 'técnica') e, por meio delas, procuramos determinar preponderâncias, ausências, semelhanças e distinções que, por hipótese, auxiliaram a melhor delimitar, por um lado, 'fases' - numa 
abordagem mais linear do tempo - e, por outro lado, permanências, rupturas, retomadas, apagamentos que entre as diferentes 'fases' ou 'períodos' - neste caso, operando também com a concepção de periodização entrelaçada que:

[...] hace justicia a la complejidad de la experiencia humana del tiempo: la experiencia "linear" del tiempo se combina con una experiencia no linear: la de procesos "laterales" y "compartidos", la de procesos cíclicos, la de antecipaciones y de "recaídas" y recuerdos"(Swiggers 2004: 120) ${ }^{16}$.

Para a discussão dessa periodização, operamos também com o conceito de 'horizonte de retrospecção' (Auroux 1992).

O 'horizonte de retrospecção' (Auroux 1992) diz respeito aos pressupostos, teorias, autores e bibliografia admitidos nos textos pelos autores. Sabemos que cada estudioso realiza um recorte em toda a produção científica antecedente da sua área. Ou seja, ao inserir-se em uma área de estudos e olhar para o passado - por exemplo, ao revisar a literatura precedente relacionada a seu tema de pesquisa -, o cientista não considera o todo, mas organiza-o, projetando os seus valores e determinando o que será tomado como referência. Cria, assim, um passado intelectual próprio, marcado por suas escolhas, hierarquizações, formas de diálogo (convergentes ou divergentes) com a 'tradição'. Supusemos que procurar reconstruir esse 'horizonte' permitiria confirmar aspectos concernentes a 'visões', 'incidências' e 'técnicas' relativos aos 'programas de investigação'.

Acrescentamos à tentativa de reconstrução do 'horizonte de retrospecção' assumido pelos autores a contextualização, isto é, ao levantamento de dados externos, tais como perfil biográfico dos autores e processos de institucionalização da área de conhecimento, bem como a outros aspectos que podem constituir certa atmosfera de época.

O estabelecimento de dados externos é tarefa necessária para o historiógrafo, pois o pensamento linguístico não se desenvolve independentemente de contingências históricas ou de correntes intelectuais vigentes em cada época. Essa contextualização mais ampla pode ajudar a evitar distorções na descrição do pensamento linguístico que se deseja reconstruir.

\footnotetext{
16 [...] faz justiça à complexidade da experiência humana do tempo: a experiência "linear" do tempo que se combina com uma experiência não linear: a de processos "laterais" e "compartilhados", a de processos cíclicos, a de antecipações e de "reincidências" e "memórias" (tradução nossa)
} 
Ao lado da composição de um material de referência sobre o tema no Brasil (trabalho 'epi-historiográfico'), nosso objetivo foi analisar historiograficamente parte dessa produção, de modo a discutir a periodização existente e a problematizar a sua divisão por fases da produção, levando em conta seus aspectos internos, (particularmente, os que dizem respeito, por um lado, à natureza e aos modos de exploração das fontes de dados linguísticos, e, por outro lado, à metodologia geral de condução dessas investigações).

Os resultados desta investigação, portanto, são de duas ordens: procuramos, por um lado, estabelecer e organizar uma bibliografia de referência acerca do tema, e, por outro lado, tentamos desenvolver um ensaio de historiografia descritiva/interpretativa, a partir de um corpus de 322 textos selecionados.

No próximo capítulo, detalhamos as opções metodológicas feitas (em parte antecipadas nesta discussão de princípios gerais). 


\section{Capítulo 2}

\section{METODOLOGIA E MATERIAIS DE PESQUISA}

Neste capítulo, apresentamos as diretrizes da pesquisa em relação aos materiais, aos critérios e aos procedimentos de análise.

\subsection{Mapeamento da produção brasileira dedicada ao contato do PB com as Línguas Africanas}

Tendo em vista a meta epi-historiográfica desta investigação, o primeiro passo dado, a partir de julho de 2014, foi a realização de um levantamento de textos que tratassem do contato entre o português do Brasil e línguas africanas.

Tal levantamento se deu a partir de revistas especializadas no tema, como a Revista Afro-Ásia (1965 - corrente) e África (1978- corrente), em sites de busca de bibliotecas de universidades, tais como a USP (Universidade de São Paulo) e UFBA (Universidade Federal da Bahia), bem como por meio do exame de currículos lattes de pesquisadores que sabíamos ser atuantes no campo. Também serviram como fontes livros de referência sobre a produção relativa às relações entre África-Brasil, como, por exemplo, Munanga (2003) e Alves (1979).

$\mathrm{O}$ número inicial de títulos aumentava à medida que incluíamos também as próprias referências bibliográficas contidas nos textos inicialmente encontrados. Chegamos, assim, a uma lista inicial de 414 textos que, em princípio, poderiam nos auxiliar a compreender os caminhos tomados pela 'tradição' de estudos da relação entre o PB e as línguas africanas deste o século XIX até o XX.

Após uma depuração dessa lista inicial, chegamos ao conjunto de 322 trabalhos organizados cronologicamente no Capítulo 3.

Nosso levantamento é composto por livros, artigos, teses e dissertações publicadas entre o século XIX e XX, sendo 2010 o último ano considerado para o 
levantamento. Dos textos selecionados, o livro de Macedo Soares (1942[1874/1891]) é o mais antigo e o artigo de Margarida Maria Taddoni Petter (2010) é o mais recente.

No processo de depuração, foram selecionados somente textos:

1) Publicados por pesquisadores brasileiros (ou estrangeiros em situação de coautoria com brasileiros, ou aqueles estabelecidos em universidades brasileiras há bastante tempo, isto é, inseridos numa dinâmica institucional local), entre o século XIX (até onde sabemos, o período em que se iniciam os estudos) e os anos 2010 (neste caso, procurando confirmar a persistência e vitalidade do tema intuídas quando iniciávamos o trabalho). A aplicação desse critério teve em vista a intenção de concentrar a pesquisa nas formas de desenvolvimento da reflexão no contexto local.

2) Cuja temática fosse, efetivamente, a relação do PB com línguas africanas. Quando dizemos "efetivamente", desejamos assinalar que, por exemplo, foram excluídos aqueles documentos que tratavam da história dos povos africanos vindos ao Brasil, de outros aspectos culturais, como música, religião, etc, ou mesmo aqueles que abordavam as línguas africanas no Brasil, sem tratar do contato com o português brasileiro; também excluímos, a partir da aplicação do mesmo critério, dicionários de português-línguas africanas ou línguas africanasportuguês, bem como gramáticas comparadas, por não se configurarem como estudos sobre o contato.

Em suma, seguimos, no processo de seleção dos textos, a diretriz de Swiggers (2013), de busca de um recorte 'temático', 'geográfico' e 'epocal', uma vez que nos interessamos particularmente pela Historiografia da Linguística Brasileira voltada para o tratamento da questão.

O recorte temático nos impôs maiores dúvidas e desafios. Em princípio, julgamos que, a partir dos títulos, teríamos elementos suficientes para tomar decisões quanto à permanência ou não de um texto na bibliografia que pretendíamos organizar sobre a questão. No entanto, foi necessário aliar esse critério a consultas à maioria dos textos (após um difícil percurso de localização) ou, quando isso não foi possível, a bibliografia que deles tratasse. 
Uma vez efetuada a seleção, os 322 trabalhos foram organizados segundo a ordem cronológica de publicação de modo que essa listagem permitisse, a nós mesmos e também a um eventual consulente dessa bibliografia que constituíamos, identificar, sobretudo, a partir de um exame dos títulos ${ }^{1}$ :

a) Possíveis tendências preponderantes a cada período histórico;

b) Possíveis concorrências entre tendências nos mesmos períodos;

c) Possíveis traços 'persistentes' ao longo do período total (século XIX a XXI);

d) Possíveis descontinuações de abordagens;

e) Possíveis lacunas.

A intenção foi elaborar um produto 'epi-historiográfico', ou seja, uma bibliografia organizada cronologicamente, mas aberta às leituras acima sugeridas, que sirva de referência aos interessados no tema e que, no caso desta investigação, permitisse obter uma melhor visão de conjunto daquilo que se produziu no Brasil sobre as relações do PB com línguas africanas ao longo dos séculos XIX, XX e XXI.

Uma vez que essa bibliografia é um dos resultados (epi-historiográfico) do nosso trabalho de análise dessa produção - resultado construído a partir da adoção e aplicação de critérios historiográficos de contextualização, periodização e análise preliminar de conteúdos - reservamos a ela um lugar de destaque nesta dissertação, o Capítulo 3.

\section{2 'Exemplares' selecionados para a análise historiográfica descritiva}

Nossa análise mais propriamente historiográfica (preocupada, fundamentalmente, em avaliar metodologia e 'fontes' de dados para a linha de pesquisa) evidentemente não contemplou todos esses 322 textos, mas um conjunto de textos 'exemplares'. A noção de 'exemplar' aqui é inspirada em Kuhn (2007[1962]): são

\footnotetext{
${ }^{1}$ É nossa intenção, em trabalho posterior em que possamos contar com mais tempo, transformar a bibliografia constituída ao longo desta pesquisa em bibliografia comentada, na qual possamos oferecer informações, evidentemente sintéticas, sobre os autores, contextos e conteúdos dos textos. Cremos que um trabalho dessa natureza possa ser de utilidade para a linha de pesquisa, que ainda não conta com um conjunto organizado de textos de referência.
} 
textos reconhecidos pela 'comunidade científica' como boas realizações científicas e tomados como modelos.

Baseamo-nos, em relação aos textos mais antigos, em sua presença em bibliografias de textos recentes, em sua menção nas diferentes revisões históricas, ou seja, no seu status de 'clássico’ da área.

A seleção de 'exemplares' mais atuais esteve sujeita aos riscos existentes ao se tentar elaborar uma história do presente, notadamente a possibilidade de enfraquecimento do juízo crítico proporcionado pelo afastamento temporal. No entanto, justamente para procurar atenuar esse efeito, optamos por selecionar trabalhos de pesquisadores atuantes há bastante tempo na área, trabalhos que possam ser considerados como exemplos das reflexões que eles vêm desenvolvendo ao longo de décadas. Assim, embora haja contemporaneamente algumas abordagens pontuais aparentemente bastante interessantes, optamos por acompanhar percursos ao menos de média duração, que sinalizem uma atuação não episódica de tratamento do tema.

Assim, dos textos reunidos em nossa bibliografia, selecionamos os seguintes, a serem analisados de acordo com nossos parâmetros 'externos' e 'internos':

1. MACEDO SOARES, Antônio Joaquim de. 1942[1874/1891]. Estudos lexicográficos do dialeto brasileiro. [Org. Julião Rangel de Macedo Soares]. Rio de Janeiro: Publicação da Revista do IHGB.

Aparentemente, o autor foi o que, ao longo do século XIX, com maior persistência abordou a questão da relação do PB com línguas africanas, como veremos no Capítulo 4 desta dissertação. A obra selecionada, uma coletânea de estudos, não está completamente voltada para o exame do tema, no entanto tratamos dos artigos e notas relativos a ele. Ainda que esse autor não seja mencionado ou ocupe uma posição marginal em diferentes revisões históricas, acreditamos que podemos reservar a ele um papel importante na história desses estudos (v. Capítulo 4.1).

2. MENDONÇA, Renato. 1935[1933]. A influência africana no português do Brasil. Prefácio de Rodolfo Garcia. São Paulo: Companhia Editora Nacional. Série V Brasiliana, Volume XLVI, $2^{a}$ edição ilustrada com mapas e gravuras.

Ao lado de Raimundo (1933), Mendonça (1935[1933]) é o texto mais frequentemente apontado como iniciador dos estudos sobre o tema. 
3. RAIMUNDO, Jacques. 1933. O elemento afro-negro na língua portuguesa. Rio de Janeiro: Renascença.

Ao lado de Mendonça 1935[1933], é o texto mais frequentemente apontado como iniciador dos estudos sobre o tema.

4. SILVA NETO, Serafim da. 1950. Introdução ao estudo da língua portuguesa no Brasil. Rio de Janeiro: Presença.

Texto também bastante mencionado em revisões históricas e nos trabalhos que se desenvolvem sobre o tema. Há adesões a algumas de suas ideias e propostas, mas, principalmente, críticas ao tratamento ambíguo de questões como a hipótese de crioulização do PB.

5. NARO, Anthony Julius; SCHERRE, Maria Marta Pereira. 2007. Origens do português brasileiro. São Paulo: Parábola.

Texto de autores que, no contexto contemporâneo, têm se dedicado ao tema com mais persistência (desde a década de 80 ) e cujas pesquisas têm tido impacto na área. Trata-se de uma reunião de artigos publicados ao longo da carreira dos autores.

6. PETTER, Margarida Maria Taddoni. 2008. Variedades lingüísticas em contato: português angolano, português brasileiro, português moçambicano. Tese de livre-docência. São Paulo, concurso para a livre docência - Faculdade de Filosofia, Letras e Ciências Humanas, Universidade de São Paulo.

Texto de autora que, no contexto contemporâneo, tem se dedicado ao tema com mais persistência e cujas pesquisas têm tido impacto na área. Analisamos a sua tese de livre-docência, que sintetiza boa parte de seu percurso acadêmico.

7. CASTRO, Yeda Pessoa. 2009. African Languages and Brazilian Portuguese: a new approach. In: PETTER, Margarida; MENDES, Ronald Beline (Org.). Exploring the African Language Connection in the Americas - Proceedings of the Special World Congress of African Linguistics (2008). São Paulo: Humanitas, p. 47-56.

Texto de autora que, no contexto contemporâneo, tem se dedicado ao tema com mais persistência e cujas pesquisas têm tido impacto na área. A pesquisadora é reconhecida, inclusive, pelas retrospectivas históricas que menciamos no Capítulo1, Bonvini (2009) e Queiroz (2002). Esse artigo foi selecionado por estar presente nos anais 
de um dos principais eventos internacionais da área de pesquisa realizado no Brasil.

8. LUCCHESI, Dante; BAXTER, Alan; RIBEIRO, Ilza. (Org.). 2009. O português afro-brasileiro. Salvador: EDUFBA.

Coletânea resultante do trabalho de um dos grupos de pesquisa que, no contexto contemporâneo, têm se dedicado ao tema com mais persistência e cujas pesquisas têm tido impacto na área. Essa coletânea é composta por diversos autores, principalmente, orientandos e ex-orientandos dos professores organizadores do volume. Entendemos que, de algum modo, eles contribuem para exemplificar a visão do problema de um dos principais grupos que dele se ocupa, o da Bahia.

Desta coletânea, selecionamos um artigo que trata da concordância de número, tema também explorado por Naro e Scherre (2009).

Nessa seleção, buscamos montar um panorama dos estudos, do século XIX ao XXI, em que cada texto (ou grupo de textos) pudesse ser tomado como 'exemplar' de uma tendência geral da área. Ou seja, foi nossa intenção que essa seleção privilegiasse textos de diferentes épocas e de distintas abordagens, às vezes, explicitamente conflitantes entre si, de modo que pudéssemos tentar apreender um pouco da diversificação e também das convergências no tratamento do tema no Brasil.

No capítulo 4, expusemos as análises sobre os textos de Macedo Soares (1942[1874/1891), Mendonça 1935[1933], Raimundo (1933) e Silva Neto (1950), segundo os parâmetros apresentados a seguir na seção 2.3. Essas obras foram integralmente analisadas (no caso de Macedo Soares, uma coletânea de textos de temática diversificada, foram analisados exclusivamente os artigos e notas relativos ao tema).

No capítulo 5, apresentamos análises panorâmicas sobre excertos dos textos de Naro \& Scherre (2007), Petter (2008), Castro (2009) e Lucchesi, Baxter \& Ribeiro (2008). Optamos, assim, por uma seleção de capítulos e/ou artigos que: 1) pudessem oferecer uma visão geral sobre a forma de tratar o tema; 2) permitissem comparações em relação às opções feitas pelos autores. 


\subsection{Parâmetros de análise dos 'exemplares' selecionados}

Posteriormente, analisamos as fontes e a metodologia de estudos empregada nos textos selecionados de acordo com a proposta de análise de Swiggers (1981a, 1991a, 2004) para definir 'programa de investigação', conceito explicado no Capítulo 1. Dessa forma, procuramos apreender a 'visão de língua' presente nos textos, a 'incidência da análise' realizada em cada um dos trabalhos e a 'técnica' preponderante nos textos selecionados. Na análise da 'incidência', incluímos dados acerca das 'fontes' utilizadas nos textos. Como vimos na revisão apresentada no Capítulo 1, os estudiosos que trataram historicamente essa produção criticam a sua fragilidade em relação às 'fontes' fidedignas de dados, ao mesmo passo em que os diferentes atores envolvidos com a área de pesquisa no país, como veremos nos Capítulos 4 e 5, queixam-se da inexistência de documentos e das dificuldades gerais de acesso aos poucos registros. Trata-se, com efeito, de uma história que se constrói de forma reconhecidamente lacunar. Diferentes estratégias metodológicas, ao longo do tempo, têm sido adotadas para lidar com esse fato, como também veremos nos capítulos 4 e 5.

Ao lado dessa análise 'interna' dos textos selecionados, procuramos contextualizá-los em relação a três aspectos essenciais:

a) o oferecimento de dados essenciais sobre os autores, em micro-biografias intelectuais, no caso dos mais afastados cronologicamente, com recurso a obituários, prefácios, revisões históricas, dicionários biográficos, outros trabalhos acadêmicos, sites.

b) a tentativa de reconstrução do 'horizonte de retrospecção' (Auroux 1992), por meio do levantamento dos principais diálogos, convergentes e divergentes, estabelecidos pelos autores com outros estudiosos e com outros textos. Procedemos, assim, ao levantamento e à análise das referências feitas nos textos, sobretudo das mais explícitas.

c) a tentativa de reconstrução de aspectos do contexto mais geral e às condições gerais de produção e de difusão do conhecimento de que dispôs cada um dos estudiosos selecionados. Essa reconstrução, como a anterior, não teve qualquer pretensão de exaustividade. Procurou apenas correlacionar certos traços dos textos a questões que talvez tenham contribuído para que eles se 
manifestassem. Assim, por exemplo, parece ter sido relevante a ausência de formação e de ambientes acadêmicos mais especializados até o começo do século XX; por outro lado, a especialização e as questões relativas à chamada 'produtividade' parecem impactar a produção mais contemporânea, como procuramos apontar nos capítulos 4 e 5 , adiante.

\subsection{Avaliação dos resultados da análise}

Feitas as análises, segundo os parâmetros elencados acima, apresentamos no Capítulo 6, os resultados mais globais de nossa investigação. O capítulo 6 organizou-se de modo a que pudéssemos discutir os dados a que chegamos nos capítulos de análise epi-historiográfica (Capítulo 3) e historiográfica (Capítulos 4 e 5). 


\section{Capítulo 3}

\section{BIBLIOGRAFIA DA PRODUÇÃO BRASILEIRA DEDICADA À RELAÇÃO DO PB COM AS LÍNGUAS AFRICANAS NO BRASIL DO SÉCULO XIX AO XXI}

Neste capítulo, inicialmente, retomamos o objetivo epi-historiográfico desta pesquisa e os critérios adotados para que ele fosse atingido. Em seguida, apresentamos o produto desta etapa da investigação: uma bibliografia acerca do tema. Finalmente, na última seção, tecemos alguns breves comentários sobre essa produção.

\subsection{Epi-historiografia das relações do PB com as Línguas Africanas}

Como vimos no primeiro capítulo desta dissertação, julgamos que o tema de que nos ocupamos carecia (e carece) de pesquisas epi-historigráficas. Entendemos, com Swiggers (2004), tais pesquisas como aquelas que, necessariamente, devem pavimentar o caminho para a elaboração de historiografias descritivas e interpretativas seguras, por meio da edição e da tradução de textos; da correção de erros correlacionados a esses dois processos; da publicação de fontes primárias; do tratamento e da disponibilização de informações biográficas sobre os 'agentes' relevantes para cada 'tradição'; da coleta e disponibilização de dados sobre exemplares de obras, arquivos, bibliotecas; da organização de bibliografias (sobre autores e textos, contextos, temas, conceitos).

Modesta e preliminarmente, esta pesquisa pretendeu contribuir para a elaboração de uma bibliografia de referência sobre o tema do contato do PB com línguas africanas. Para tanto, efetuamos um amplo mapeamento de textos publicados entre os séculos XIX e XX, descrito no Capítulo 2 deste trabalho. Diante de 414 de textos (entre livros, teses e dissertações, ensaios, artigos, notas), procedemos à sua busca e, em seguida, a uma tentativa de seleção que nos levasse a um conjunto de trabalhos que efetivamente tratassem do tema, já que, de forma difusa, a questão perpassa um sem-número de textos. Assim, como já adiantamos no capítulo anterior, elegemos estudos:

a) publicados por pesquisadores brasileiros (ou estrangeiros em situação de coautoria com brasileiros, ou aqueles estabelecidos em universidades brasileiras há 
bastante tempo), uma vez que nos interessamos, particularmente, pelo desenvolvimento da tradição de tratamento desse tema no Brasil;

b) cuja temática reservasse um lugar importante para o estudo da relação do PB com línguas africanas (ainda que essa relação pudesse ser menos centralmente explorada nos textos, ela tinha de ser um de seus eixos. Desse modo, por exemplo, não incluímos trabalhos dedicados ao tratamento exclusivo de línguas africanas, sem preocupação com sua relação com o $\mathrm{PB}$, nem textos sobre outros aspectos da contribuição africana para a configuração da sociedade brasileira que não atentassem particularmente para tal relação);

c) não integralmente repetidos, isto é, na ocorrência de publicações idênticas, selecionamos apenas uma para constar desse elenco.

Como também mencionamos no capítulo anterior, concluída a seleção, os 322 trabalhos dela resultantes foram organizados segundo a ordem cronológica de publicação, de modo que essa listagem permitisse, a nós mesmos e também a um eventual consulente dessa bibliografia que constituíamos, conjecturar, sobretudo a partir de um exame dos títulos:

a) possíveis tendências preponderantes em cada período histórico;

b) possíveis concorrências entre tendências nos mesmos períodos;

c) possíveis traços 'persistentes' ao longo do período total (século XIX a XXI);

d) possíveis descontinuações de abordagens;

e) possíveis lacunas.

A intenção foi elaborar uma bibliografia, organizada cronologicamente, mas aberta às leituras acima sugeridas, que servisse de referência aos interessados no tema e que, no caso desta investigação, permitisse obter uma melhor visão de conjunto daquilo que se produziu no Brasil sobre as relações do PB com línguas africanas ao longo dos séculos XIX, XX e XXI. O corte temporal adotado para a finalização desta etapa foi 2010.

O resultado desse processo é o seguinte: 
3.2 Bibliografia sobre a relação entre o PB e as línguas africanas no Brasil, do século XIX ao XXI, em ordem cronológica de publicação

\begin{tabular}{|c|c|}
\hline $\begin{array}{c}\text { DATA DE } \\
\text { PUBLICAÇÃO }\end{array}$ & OUTROS DADOS BIBLIOGRÁFICOS \\
\hline $1874-1891$ & $\begin{array}{l}\text { MACEDO SOARES, Antônio Joaquim de. Estudos lexicográficos do } \\
\text { dialeto brasileiro. [Org. Julião Rangel de Macedo Soares]. Rio de } \\
\text { Janeiro: Publicação da Revista do IHGB, 1942[1874-1891]. }\end{array}$ \\
\hline 1920 & $\begin{array}{l}\text { AMARAL, Amadeu. } O \text { dialeto caipira: gramática, vocabulário. } 4^{\mathrm{a}} \text { ed. } \\
\text { São Paulo: Hucitec / Brasília: INL, } 1982 \text { (reprod. facsimil da } 2^{\mathrm{a}} \text { ed; } 1^{\mathrm{a}} \\
\text { ed. 1920). }\end{array}$ \\
\hline 1921 & $\begin{array}{l}\text { PONTES, Hildebrando Araújo. Influência da linguagem africana do } \\
\text { negro na formação do 'dialeto capiáu". Jornal do Commercio, Rio de } \\
\text { Janeiro, } 24 \text { de agosto } 1921 \text {. }\end{array}$ \\
\hline 1921 & $\begin{array}{l}\text { RIBEIRO, João. A língua nacional e outros estudos lingüísticos. } \\
\text { Seleção e coord. de Hildon Rocha. Petrópolis: Vozes/Aracaju: } \\
\text { Governo do Estado de Sergipe, 1979[1921]. }\end{array}$ \\
\hline 1921 & $\begin{array}{l}\text { SENNA, Nelson de. Africanismos no Brasil. Revista de Língua } \\
\text { Portuguesa, n.10, p.159-163, mar. 1921. }\end{array}$ \\
\hline 1922 & $\begin{array}{l}\text { LEITE, Solidônio. A lingua portuguesa no Brasil. Rio de Janeiro: } \\
\text { Editores J. Leite e Cia, } 1922 \text {. }\end{array}$ \\
\hline 1923 & $\begin{array}{l}\text { SENNA, Nelson de. Contribuições para a ethnologia brasileira: os } \\
\text { negros (elementos de origem africana e seus descendentes). Revista de } \\
\text { Língua Portuguesa, n.22, p.136-149, mar. } 1923 \text {. }\end{array}$ \\
\hline 1930 & $\begin{array}{l}\text { RIBEIRO, João. O elemento negro: História, Folklore e Linguística. } \\
\text { Petrópolis: Editora Record, } 1930 .\end{array}$ \\
\hline 1931 & $\begin{array}{l}\text { MONTEIRO, Clóvis. Português da Europa e Português da América - } \\
\text { Aspectos da evolução do nosso idioma. Rio de Janeiro: J. Leite, } 1931 .\end{array}$ \\
\hline $1932 *$ & $\begin{array}{l}\text { RODRIGUES, Raymundo Nina. Os africanos no Brasil. São Paulo: } \\
\text { Nacional, } 1932 \text {. }\end{array}$ \\
\hline
\end{tabular}




\begin{tabular}{|c|c|}
\hline & $\begin{array}{l}\text { *Obra publicada postumamente; segundo revisores, elaborada entre } \\
1890 \text { e } 1905 .\end{array}$ \\
\hline 1933 & $\begin{array}{l}\text { RAYMUNDO, Jacques. } O \text { elemento afro-negro na língua } \\
\text { portuguesa. Rio de Janeiro: Renascença, } 1933 \text {. }\end{array}$ \\
\hline 1933 & 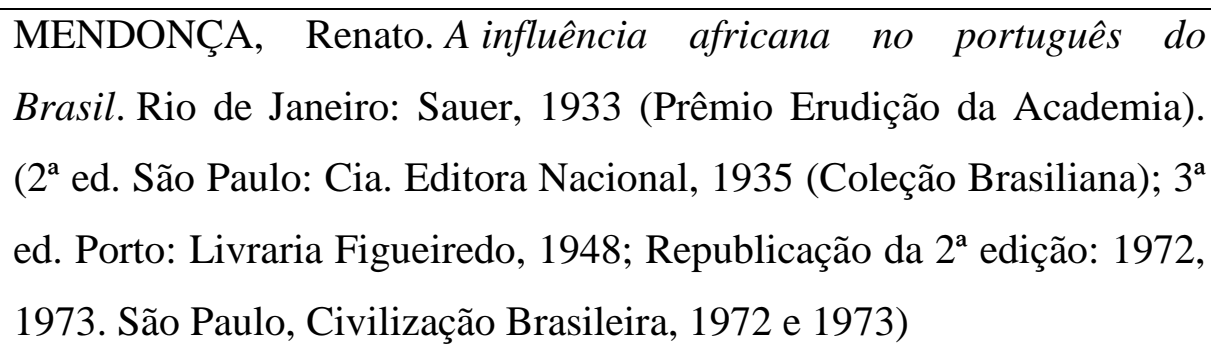 \\
\hline 1936 & $\begin{array}{l}\text { LAYTANO, Dante de. Os africanismos do dialeto gaúcho. Separata da } \\
\text { Revista do Instituto Histórico e Geográfico do Rio Grande do } \\
\text { Sul, Porto Alegre, v.16, n.2, p.7-66, } 1936 \text {. }\end{array}$ \\
\hline 1936 & $\begin{array}{l}\text { MENDONÇA, Renato. O Português do Brasil: origem, evolução e } \\
\text { tendências. Rio de Janeiro: Civilização Brasileira, } 1936 \text {. }\end{array}$ \\
\hline 1937 & $\begin{array}{l}\text { JUCÁ FILHO, Cândido. Língua Nacional-As diferenciações entre o } \\
\text { português de Portugal e o do Brasil autorizam a existência de um } \\
\text { ramo dialetal do português penin-sular? Rio de Janeiro: } \\
\text { Estabelecimento gráphico Apollo, } 1937 \text {. }\end{array}$ \\
\hline 1937 & $\begin{array}{l}\text { RAMOS, Arthur. As culturas negras no novo mundo. Rio de Janeiro: } \\
\text { Civilização Brasileira, } 1937 .\end{array}$ \\
\hline 1938 & $\begin{array}{l}\text { SENNA, Nelson de. Africanos no Brasil: estudos sobre os negros } \\
\text { africanos e influências sobre a linguagem e costumes do povo } \\
\text { brasileiro. Belo Horizonte: Of. Gráf. Queiroz Breyner, } 1938 \text {. }\end{array}$ \\
\hline 1939 & LEDA, João. A quimera da lingua brasileira. Manaus: S. Ed, 1939. \\
\hline 1940 & $\begin{array}{l}\text { ELIA, Sílvio. O problema da língua brasileira. Rio de Janeiro: } \\
\text { Instituto Nacional do Livro/Ministério da Educação e Cultura, } \\
\text { 1961[1940]. }\end{array}$ \\
\hline 1940 & $\begin{array}{l}\text { MENDONÇA, Renato. O negro e a cultura no Brasil: breve histórico } \\
\text { de estudos afro-brasileiros de linguística, etnografia e sociologia. In: } \\
\text { HERSKOVITS, Melville et al. } O \text { negro no Brasil: trabalhos } \\
\text { apresentados ao II Congresso Afro-Brasileiro (Bahia). Rio de Janeiro: } \\
\text { Civilização Brasileira, p. 99-125, 1940. Biblioteca de divulgação }\end{array}$ \\
\hline
\end{tabular}




\begin{tabular}{|c|c|}
\hline & científica, 20 . \\
\hline 1940 & $\begin{array}{l}\text { RAYMUNDO, Jacques. Sugestões. In: HERSKOVITS, M. J. et al. } O \\
\text { negro no Brasil; trabalhos apresentados ao II Congresso Afro- } \\
\text { Brasileiro (Bahia). Rio de Janeiro: Civilização Brasileira, p.359-363, } \\
\text { 1940. (Biblioteca de Divulgação Científica, 20). }\end{array}$ \\
\hline 1940 & $\begin{array}{l}\text { RAMOS, Arthur. Nina Rodrigues e os estudos negro-brasileiros. In: } \\
\text { HERSKOVITS, Melville J. et al. O negro no Brasil; trabalhos } \\
\text { apresentados ao II Congresso Afro-Brasileiro (Bahia), Rio de Janeiro: } \\
\text { Civilização Brasileira, p. 337-339, 1940. (Biblioteca de Divulgação } \\
\text { Científica, 20). }\end{array}$ \\
\hline 1940 & $\begin{array}{l}\text { SANCHES, Edgard. Língua brasileira. São Paulo/Rio de } \\
\text { Janeiro/Recife/Porto Alegre: Cia. Editora Nacional, } 1940\end{array}$ \\
\hline 1940 & $\begin{array}{l}\text { NEIVA, Arthur. Estudos da Língua Nacional. São Paulo: Companhia } \\
\text { Editora Nacional, Coleção Braziliana, vol. 178, 1940. Disponível em: } \\
\text { http://www.brasiliana.com.br/brasiliana/colecao/obras/129/estudos-da- } \\
\text { lingua-nacional Acesso em: 21/02/2013. }\end{array}$ \\
\hline 1941 & $\begin{array}{l}\text { CASTRO, Comandante Eugênio de. Ensaios de Geographia } \\
\text { lingüística e cultura brasileira. Rio de Janeiro: Graphica Sauer, } 1941 . \\
\text { Disponível: } \\
\text { http://www.brasiliana.com.br/brasiliana/colecao/obras/154/Ensaios-de- } \\
\text { geografia-linguistica Acesso em 08/02/2013. }\end{array}$ \\
\hline 1941 & $\begin{array}{l}\text { SILVA NETO, Serafim da. A origem do dialeto brasileiro. Revista } \\
\text { Filológica. } 9 \text {, p. } 45-49,1941 \text {. }\end{array}$ \\
\hline 1946 & $\begin{array}{l}\text { MELO, Gladstone Chaves de. A língua do Brasil. [s.1.]: Lucas/Agir, } \\
1946 .\end{array}$ \\
\hline 1950 & $\begin{array}{l}\text { SILVA NETO, Serafim da. Introdução ao estudo da língua portuguesa } \\
\text { no Brasil. Rio de Janeiro: MES/INL/Departamento de Imprensa } \\
\text { Nacional, } 1950 \text {. }\end{array}$ \\
\hline 1951 & $\begin{array}{l}\text { CARNEIRO, Edison. A linguagem popular da Bahia. Rio de Janeiro: } \\
\text { [s.d.], } 1951 .\end{array}$ \\
\hline 1954 & $\begin{array}{l}\text { BUENO, Francisco da Silveira. Estudos de Filologia portuguesa. São } \\
\text { Paulo: Saraiva } 1954 .\end{array}$ \\
\hline
\end{tabular}




\begin{tabular}{|c|c|}
\hline 1954 & $\begin{array}{l}\text { BUENO, Francisco da Silveira. "Influencia das línguas africanas no } \\
\text { português do Brasil". Jornal de Filologia, Lisboa, vol. 2, fasc. 3, pp. } \\
217-31,1954 \text {. }\end{array}$ \\
\hline 1955 & $\begin{array}{l}\text { BUENO, Francisco da Silveira. A formação histórica da língua } \\
\text { portuguesa. Rio de Janeiro: Livraria Acadêmica, } 1955 \text {. }\end{array}$ \\
\hline 1955 & $\begin{array}{l}\text { SILVA NETO, Serafim da. História da língua portuguêsa. } \\
\text { Florianópolis: Faculdade Catarinense de Filosofia, } 1955 .\end{array}$ \\
\hline 1960 & $\begin{array}{l}\text { SILVA NETO, Serafim da. A língua portuguesa no Brasil: } \\
\text { problemas. Rio de Janeiro: Acadêmica, } 1960 .\end{array}$ \\
\hline 1963 & $\begin{array}{l}\text { ELIA, Sílvio. Ensaios de filologia. Rio de Janeiro: Livraria } \\
\text { Acadêmica, 1963. }\end{array}$ \\
\hline 1963 & $\begin{array}{l}\text { ROSSI, Nelson. Atlas prévio dos falares baianos. [Rio de Janeiro]: } \\
\text { MEC/INL, } 1963 .\end{array}$ \\
\hline 1965 & $\begin{array}{l}\text { CASTRO, Yeda Pessoa. Noticia de uma Pesquisa em África. Afro-Asia } \\
\text { (UFBA), Salvador, v. 01, p. 41-56, } 1965 \text {. }\end{array}$ \\
\hline 1967 & $\begin{array}{l}\text { CASTRO, Yeda Pessoa. A Sobrevivência das Línguas Africanas no } \\
\text { Brasil: sua influência na linguagem popular da Bahia. Afro-Asia } \\
\text { (UFBA), Salvador, v. 4-5, p. } 25-34,1967 \text {. }\end{array}$ \\
\hline 1967 & $\begin{array}{l}\text { CASTRO, Yeda Pessoa. Réplicas Populares. Revista Brasileira de } \\
\text { Folclore, Rio de Janeiro, v. 18, p. 117-138, } 1967 .\end{array}$ \\
\hline 1967 & $\begin{array}{l}\text { SILVEIRA BUENO, Francisco. A formação histórica da língua } \\
\text { portuguesa. São Paulo: Saraiva, } 1967 .\end{array}$ \\
\hline 1968 & $\begin{array}{l}\text { Revista Brasileira de Folclore, Rio de Janeiro, MEC, Campanha de } \\
\text { Defesa do Folclore Brasileiro, v.8, n. 21, p.119-128, maio/ago. } 1968 . \\
\text { http://docvirt.com/atualizacao/goglobal/formFF.asp }\end{array}$ \\
\hline 1968 & $\begin{array}{l}\text { CASTRO, Yeda Pessoa. Etnônimos Africanos e Formas Ocorrentes no } \\
\text { Brasil. Afro-Asia (UFBA), Salvador, v. 6-7, p. 63-82, } 1968 .\end{array}$ \\
\hline 1969 & $\begin{array}{l}\text { FERREIRA, Carlota. "Remanescentes de um falar crioulo brasileiro: } \\
\text { Helvécia-Bahia." In: FERREIRA, Carlota et al. Diversidade do } \\
\text { Português do Brasil. Salvador: PROED/UFBA, 1969, p. 21-31. }\end{array}$ \\
\hline 1972 & $\begin{array}{l}\text { BARBOSA, Waldemar de Almeida. Negros e quilombos em Minas } \\
\text { Gerais. Belo Horizonte: [Imprensa Oficial], } 1972 \text {. }\end{array}$ \\
\hline
\end{tabular}




\begin{tabular}{|c|c|}
\hline 1972 & $\begin{array}{l}\text { CAMARA Jr., Mattoso. Línguas européias de ultramar: o português do } \\
\text { Brasil. In: Câmara Jr., Mattoso. Dispersos. Seleção e introdução por } \\
\text { Carlos Eduardo Falcão Uchôa. Rio de Janeiro: FGV, 1972[1963], p. } \\
\text { 71-87. }\end{array}$ \\
\hline 1974 & $\begin{array}{l}\text { RODRIGUES, Ada Natal. } O \text { dialeto caipira na região de } \\
\text { Piracicaba. São Paulo: Ática, 1974. (Col. Ensaios, 5). }\end{array}$ \\
\hline 1975 & $\begin{array}{l}\text { CHAVES DE MELO, Gladstone. A língua do Brasil. Rio de Janeiro: } \\
\text { FGV, } 1975 \text {. }\end{array}$ \\
\hline 1976 & $\begin{array}{l}\text { CASTRO, Yeda Pessoa. Colaboração à Antropologia Lingüística nos } \\
\text { Estudos Afro-Brasileiros. In: MARTINS, Cléo; LODI, Raul. (Org.). } \\
\text { Faraimara: O Caçador Traz a Alegria. Rio de Janeiro: Pallas, 2000, p. } \\
\text { 81-97. Publicado também em CASTRO, Yeda Pessoa. Antropologia e } \\
\text { Lingüística nos Estudos Afro-Brasileiros. Afro-Asia (UFBA), } \\
\text { Salvador, v. 12, p. 211-228, } 1976 \text {. }\end{array}$ \\
\hline 1976 & $\begin{array}{l}\text { CASTRO, Yeda Pessoa. De l'intégration de apports africains dans les } \\
\text { parlers de Bahia au Brésil. Lubumbashi, 1976. Tese (Doutorado em } \\
\text { línguas e literaturas africanas). Université Nationale du Zäire, 2v. } \\
\text { Universidade Federal da Bahia. }\end{array}$ \\
\hline 1976 & $\begin{array}{l}\text { OLIVEIRA, Waldir Freitas. Desenvolvimento dos estudos africanistas } \\
\text { no Brasil. Cultura, Brasília: MEC, v.6, n.23, p.110-117, out./dez. } 1976 .\end{array}$ \\
\hline 1977 & 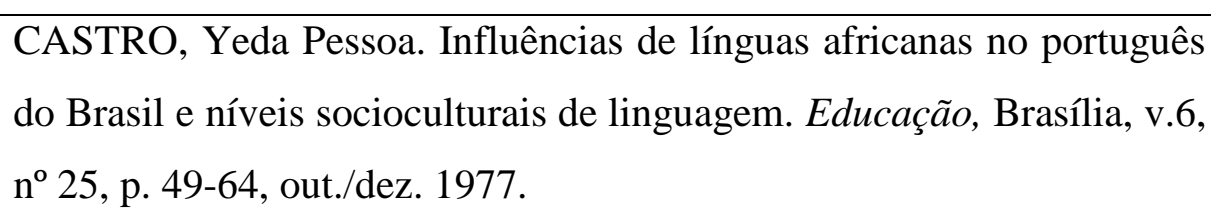 \\
\hline 1978 & $\begin{array}{l}\text { ALCÂNTARA, Edson Mário de. O negro e a linguagem: influências } \\
\text { do negro na formação da língua no Brasil. Scientia ad Sapientiam, } \\
\text { Maceió, v. } 1 \text {, n. } 2 \text {, p. } 71-4 \text {, dez. } 1978 \text {. }\end{array}$ \\
\hline 1978 & $\begin{array}{l}\text { CARVALHO, Felix de. Falares crioulos do Brasil: um tema em } \\
\text { debate. Rio de Janeiro, 1978. Dissertação (Mestrado em Linguística) - } \\
\text { Departamento de Letras, Pontifícia Universidade Católica (PUC). }\end{array}$ \\
\hline 1978 & $\begin{array}{l}\text { VOGT, Carlos. Cafundó: uma Comunidade Negra no Brasil que fala } \\
\text { até hoje uma língua de origem africana. Revista de Estudos } \\
\text { Lingüísticos, Bauru, v. 2, p. 11-19, } 1978 \text {. }\end{array}$ \\
\hline 1979 & ELIA, Sílvio. A unidade linguística no Brasil. Rio de Janeiro: Padrão, \\
\hline
\end{tabular}




\begin{tabular}{|c|c|}
\hline & 1940. \\
\hline 1979 & $\begin{array}{l}\text { MATTOS e SILVA, Rosa Virgínia. Aspectos do contato lingüístico no } \\
\text { Brasil. Universitas, Salvador, n.24, p. 83-95, } 1979 .\end{array}$ \\
\hline 1980 & $\begin{array}{l}\text { CASTRO, Yeda Pessoa. África descoberta: uma história recontada. } \\
\text { Revista de Antropologia (São Paulo), São Paulo, v. 23, p. 135-140, } \\
1980 .\end{array}$ \\
\hline 1980 & $\begin{array}{l}\text { FRY, Peter; VOGT, Carlos, GNERRE, Maurizio. Las lenguas secretas } \\
\text { de Cafundó. Punto de vista, v.9, n. 3, p.26-32, } 1980 \text {. }\end{array}$ \\
\hline 1981 & $\begin{array}{l}\text { LAYTANO, Dante de. O linguajar do gaúcho brasileiro. Porto } \\
\text { Alegre: Escola Superior de Teologia São Lourenço de Brindes, } 1981 .\end{array}$ \\
\hline 1983 & $\begin{array}{l}\text { CASTRO, Yeda Pessoa. Das Línguas Africanas ao Português } \\
\text { Brasileiro. Afro-Asia (UFBA), Salvador, v. 14, p. 81-106, } 1983 .\end{array}$ \\
\hline 1983 & $\begin{array}{l}\text { CASTRO, Yeda Pessoa. L'Afrique Au Brésil, une Nouvelle Approche. } \\
\text { Recherche Pédagogie Et Culture, Paris, nº 64, p. 7-10, } 1983 .\end{array}$ \\
\hline 1983 & $\begin{array}{l}\text { FRY, Peter Henry; VOGT, Carlos. A Descoberta do Cafundó. Religião } \\
\text { \& Sociedade, Rio de Janeiro, v. 8, p. 24-40, } 1983 .\end{array}$ \\
\hline 1983 & $\begin{array}{l}\text { FRY, Peter Henry; VOGT, Carlos Alberto. Ditos e Feitos da Falange } \\
\text { Africana do Cafundó e da Calunga de Patrocínio. Revista de } \\
\text { Antropologia (São Paulo), São Paulo, v. XXVI, p. 65-93, } 1983 \text {. }\end{array}$ \\
\hline 1984 & $\begin{array}{l}\text { QUEIROZ, Sônia. A língua do negro da costa: um remanescente } \\
\text { africano em Bom Despacho (MG). Belo Horizonte, 1984. Dissertação } \\
\text { (Mestrado em Linguística) - Faculdade de Letras, Universidade } \\
\text { Federal de Minas Gerais. }\end{array}$ \\
\hline 1984 & $\begin{array}{l}\text { FRY, Peter; VOGT, Carlos e GNERRE, Maurizio. Mafambura e } \\
\text { Caxapura: na encruzilhada da identidade. Dados - Revista de Ciências } \\
\text { Sociais, Rio de Janeiro, v. 24, } \mathrm{n}^{\circ} \text { 3, p. 373-389, 1981. Publicado } \\
\text { também (1) FRY, Peter (Org.). Para inglês ver: identidade e política } \\
\text { na cultura brasileira. Rio de Janeiro: Zahar, p. 116-135, 1982. (2) } \\
\text { Cadernos de Estudos Linguísticos, } \mathrm{n}^{\circ} \text { 6, p. 111-124, 1984. }\end{array}$ \\
\hline 1985 & $\begin{array}{l}\text { HOUAISS, Antônio. O português no Brasil: pequena enciclopédia da } \\
\text { cultura brasileira. Rio de Janeiro: UNIBRADE, } 1985 \text {. }\end{array}$ \\
\hline 1985 & $\begin{array}{l}\text { QUEIROZ, Sônia. A língua do negro da Costa: um pidgin em Minas } \\
\text { Gerais?. Duas Palavras, Belo Horizonte, v. 1, n.2, p. 17-21, } 1985 \text {. }\end{array}$ \\
\hline
\end{tabular}




\begin{tabular}{|c|c|}
\hline 1985 & $\begin{array}{l}\text { VOGT, Carlos; FRY, Peter. Rios de cristal: contos e desencontros de } \\
\text { línguas africanas no Brasil. Cadernos de estudos lingüísticos, v. 8, p. } \\
\text { 109-128, 1985b. }\end{array}$ \\
\hline 1986 & $\begin{array}{l}\text { QUEIROZ, Sônia. A língua dos negros da Tabatinga. Minas Gerais - } \\
\text { Suplemento Literário, Belo Horizonte, v. 1033, p. 14, } 1986 .\end{array}$ \\
\hline 1986 & $\begin{array}{l}\text { QUEIROZ, Sônia. A língua do Negro da Costa: um pidgin em Minas } \\
\text { Gerais?. Boletim do Cesp, Belo Horizonte, v. 13, n.15, p. 94-105, } \\
\text { 1986. }\end{array}$ \\
\hline 1986 & $\begin{array}{l}\text { TARALLO, Fernando. On the allege creoule origin of Brazilian } \\
\text { Portuguese: Untargeted Syntatic Change. Trabalho apresentado no } \\
\text { Creole Workshop, LSA Institute, City University of New York, } 1986 .\end{array}$ \\
\hline 1987 & $\begin{array}{l}\text { TARALLO, Fernando; ALKMIN, Tânia. Falares crioulos: línguas em } \\
\text { contato. São Paulo: Ática, } 1987 .\end{array}$ \\
\hline 1988 & $\begin{array}{l}\text { TRINDADE-SERRA, Ordep José. Dois estudos afro-brasileiros. } \\
\text { Salvador: Centro Editorial e Didático da UFBA, } 1988 .\end{array}$ \\
\hline 1989 & 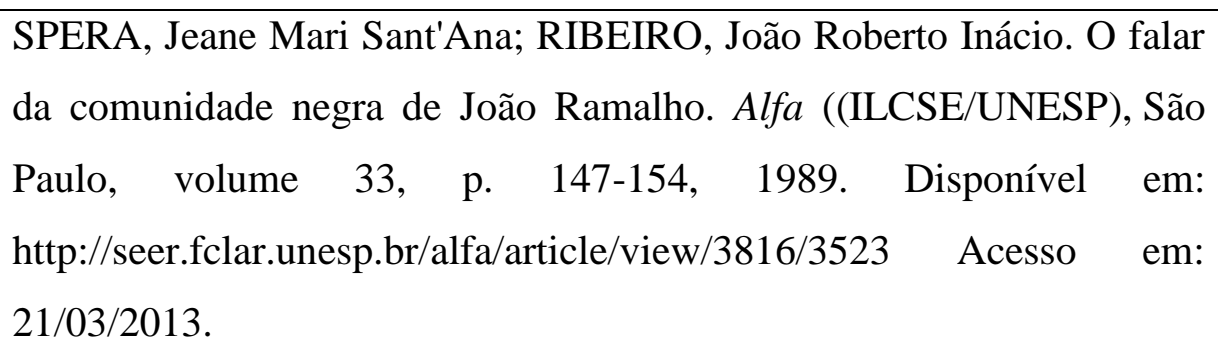 \\
\hline 1990 & $\begin{array}{l}\text { CASTRO, Yeda Pessoa. Os Falares Africanos na Interação Social do } \\
\text { Brasil Colônia. In: MELLO, Linalda de Arruda (Org.). Sociedade, } \\
\text { Cultura e Língua. João Pessoa: Editora Shorin, 1990, v. 01, p. 91-113. }\end{array}$ \\
\hline 1991 & $\begin{array}{l}\text { MUSSA, Alberto. O papel das línguas africanas na história do } \\
\text { português do Brasil. Rio de Janeiro, 1991. Dissertação (Mestrado em } \\
\text { Lingüística) - Faculdade de Letras, Universidade Federal do Rio de } \\
\text { Janeiro. }\end{array}$ \\
\hline 1992 & $\begin{array}{l}\text { CARENO, Mary Francisca do. A linguagem rural do Vale do Ribeira: } \\
\text { a voz e a vez das comunidades negras. Assis, 1992. Tese (Doutorado } \\
\text { em Filologia e Linguística Portuguesa) - Faculdade de Ciências e } \\
\text { Letras, Universidade Estadual Paulista. }\end{array}$ \\
\hline 1992 & $\begin{array}{l}\text { ELIA, Sílvio; CASTILHO, Ataliba Teixeira de. O Português do } \\
\text { Brasil. Apêndice ao livro de ILARI, Rodolfo. Linguística }\end{array}$ \\
\hline
\end{tabular}




\begin{tabular}{|c|c|}
\hline & $\begin{array}{l}\text { Românica. São Paulo, Ática, 1992, } 185 \text { p., IN Confluência, Revista do } \\
\text { Instituto de Língua Portuguesa do Liceu Literário Português, n. }{ }^{\circ} \text { 5, } \\
\text { pp.88-104, Rio de Janeiro, Ed. Lucerna Ltda., } 1^{\text {o }} \text { semestre de } 1993 .\end{array}$ \\
\hline 1992 & $\begin{array}{l}\text { SLENES, Robert Wayne Andrew. "Malungu, ngoma vem!": África } \\
\text { coberta e descoberta do Brasil. Revista da USP, número 12: 48-67, } \\
\text { 1992. Disponível em: http://www.usp.br/revistausp/12/06-robert.pdf. } \\
\text { Acesso em 18/03/13. }\end{array}$ \\
\hline 1993 & $\begin{array}{l}\text { ANDRADE FILHO, Sílvio Vieira de. Um estudo sociolinguístico da } \\
\text { comunidade negra do Cafundó. São Paulo, 1993. Tese (Doutorado em } \\
\text { Linguística) - Faculdade de Filosofia, Letras e Ciências Humanas, } \\
\text { Universidade de São Paulo. }\end{array}$ \\
\hline 1993 & $\begin{array}{l}\text { BAXTER, Alan; LUCCHESI, Dante. Processos de descrioulização no } \\
\text { sistema verbal de um dialeto rural brasileiro. Papia - Revista de } \\
\text { Crioulos de Base Ibérica, Brasília, Universidade de Brasília, v.2, n.2, } \\
\text { p. 59-71, } 1993 \text {. }\end{array}$ \\
\hline 1993 & $\begin{array}{l}\text { MATTOS e SILVA, Rosa Virgínia. Português brasileiro: raízes e } \\
\text { trajetórias (Para a construção de uma história). Discursos, Lisboa, n.3, } \\
\text { p. } 75-92,1993 \text {. }\end{array}$ \\
\hline 1993 & $\begin{array}{l}\text { MELLO, Heliana Ribeiro de. A comparison of Brazilian Vernacular } \\
\text { Portuguese and São Tomense Creole. New York, 1993. Dissertação } \\
\text { (Mestrado em Linguística) - City University of New York (CUNY). }\end{array}$ \\
\hline 1993 & $\begin{array}{l}\text { PETTER, Maria Margarida Taddoni. Perspectivas para o estudo de } \\
\text { línguas africanas no Brasil. Boletim da Associação Brasileira de } \\
\text { Lingüística, São Paulo, v. 1. p. 325-332, } 1993 \text {. }\end{array}$ \\
\hline 1993 & $\begin{array}{l}\text { TARALLO, Fernando. "Sobre a alegada origem crioula do português } \\
\text { brasileiro: mudanças sintáticas aleatórias". IN: ROBERTS, Ian; } \\
\text { KATO, Mary (org.) O português brasileiro: uma viagem diacrônica. } \\
\text { Homenagem a Fernando Tarallo. Campinas: Unicamp, p. 35-68, } 1993 \text {. }\end{array}$ \\
\hline 1994 & $\begin{array}{l}\text { BATINGA, Gastão. Aspectos da presença do negro no Triângulo } \\
\text { Mineiro/Alto Paranaíba: Kalunga. Uberlândia: Ed. do autor, } 1994 .\end{array}$ \\
\hline 1994 & $\begin{array}{l}\text { CARENO, Mary Francisca do; PETTER, Margarida Maria Taddoni. } \\
\text { Observações Sobre O Uso da Negativa. Papia, THESAURUS, } \\
\text { BRASILIA/DF, v. } 3, \mathrm{n}^{\circ} \text { 2, p. 98-109, } 1994 \text {. }\end{array}$ \\
\hline
\end{tabular}




\begin{tabular}{|c|c|}
\hline 1994 & $\begin{array}{l}\text { GONÇALVES, Eugênia Dias. Os falares de Angola da Irmandade do } \\
\text { Rosário de Belo Horizonte. FUNDAC Informa, Belo Horizonte, p. 5, } \\
\text { [1994?]. }\end{array}$ \\
\hline 1995 & $\begin{array}{l}\text { ALKMIM, Tânia Maria. Linguagem de escravos: estudo de um caso de } \\
\text { representação. Leitura: Teoria e Prática, Campinas, v. 25, p. 42-46-, } \\
1995 .\end{array}$ \\
\hline 1995 & $\begin{array}{l}\text { CASTRO, Yeda Pessoa. Dimensão dos aportes africanos no Brasil. In: } \\
\text { BACELAR, Jeferson; PEREIRA, Claudio. (Org.). Vivaldo da Costa } \\
\text { Lima, interprete afro-brasileiro. Salvador: EDUFBA, 2007, p. 177-. } \\
\text { Publicado também em CASTRO, Yeda Pessoa. Dimensão dos Aportes } \\
\text { Africanos no Brasil. Afro-Asia (UFBA), Salvador, v. 16, p. 24-35, } \\
1995 \text {. }\end{array}$ \\
\hline 1995 & $\begin{array}{l}\text { CUNHA, Ana Stela de Almeida. Remanescentes de línguas crioulas } \\
\text { em comunidades negras rurais isoladas: ausência de concordância de } \\
\text { gênero na linguagem do Cafundó. Anais do Gel, São Paulo, } 1995 \text {. }\end{array}$ \\
\hline 1995 & $\begin{array}{l}\text { GONÇALVES, Eugênia Dias. O vocabulário dos Tata n' Ganga } \\
\text { Mukice da Irmandade de N. S. do Rosário do Bairro Jatobá, Belo } \\
\text { Horizonte, Minas Gerais. Belo Horizonte: FAFI-BH, } 1995 \text {. }\end{array}$ \\
\hline 1995 & $\begin{array}{l}\text { MATTOS e SILVA, Rosa Virgínia. A sócio-história do Brasil e a } \\
\text { heterogeneidade do português brasileiro. ABRALIN (Curitiba), São } \\
\text { Paulo, n.17, p. } 73-85,1995 \text {. }\end{array}$ \\
\hline 1995 & $\begin{array}{l}\text { PETTER, Maria Margarida Taddoni. A contribuição das comunidades } \\
\text { negras isoladas para a caracterização do português brasileiro. Estudos } \\
\text { Lingüísticos (São Paulo), Ribeirão Preto, v. XXIV, p. 543-549, } 1995 \text {. }\end{array}$ \\
\hline 1996 & $\begin{array}{l}\text { ALKMIM, Tânia Maria. Linguagem de escravos: em busca de } \\
\text { registros históricos. Estudos Portugueses e Africanos, Campinas, v. 28, } \\
\text { p. 63-71, 1996. }\end{array}$ \\
\hline 1996 & $\begin{array}{l}\text { ARAGÃO, Maria do Socorro Silva. A presença africana nos falares } \\
\text { nordestinos. Confluência, Rio de Janeiro: Instituto de Língua } \\
\text { Portuguesa, } \mathrm{n}^{\circ} 12 \text {, p. } 87-100,2^{\circ} \text { semestre de } 1996 \text {. }\end{array}$ \\
\hline 1996 & $\begin{array}{l}\text { VOGT, Carlos, FRY, Peter. Cafundó: a África no Brasil: língua e } \\
\text { sociedade. São Paulo: Companhia das Letras/ Campinas: Editora } \\
\text { Unicamp, } 1996 .\end{array}$ \\
\hline
\end{tabular}




\begin{tabular}{|c|c|}
\hline 1997 & $\begin{array}{l}\text { BAXTER, Alan; LUCCHESI, Dante; GUIMARÃES, Maximiliano. } \\
\text { Gender agreement as a decreolizing feature of the Afro-Brazilian rural } \\
\text { dialect of Helvécia. Journal of Pidgin and Creole Languages, } \\
\text { Filadélfia/Amsterdam, v.12, n.1, p.1-57, } 1997 \text {. }\end{array}$ \\
\hline 1997 & $\begin{array}{l}\text { BAXTER, Alan Norman; LUCCHESI, Dante. A relevância dos } \\
\text { processos de pidginização e crioulização na formação da língua } \\
\text { portuguesa no Brasil. Estudos Lingüísticos e literários, Salvador, n } 19 \text {, } \\
\text { pp. } 65-84 \text {, set.1997. }\end{array}$ \\
\hline 1997 & $\begin{array}{l}\text { MATTOS e SILVA, Rosa Virgínia. A formação de uma área dialetal } \\
\text { do português. Papiá. Revista de crioulos de base ibérica, Brasília, v. } \\
\text { 09, p. 09-19, } 1997 \text {. }\end{array}$ \\
\hline 1997 & $\begin{array}{l}\text { MELLO, Heliana Ribeiro de. The Genesis and Development of } \\
\text { Brazilian Vernacular Portuguese. Ann Arbor: University Microfilm } \\
\text { International, v. 1, } 1997 .\end{array}$ \\
\hline 1997 & $\begin{array}{l}\text { VIEIRA, Sílvia. A não concordância em dialetos populares: uma regra } \\
\text { variável. Grafos, João Pessoa, n. 2, v. 1, p. 115-34, } 1997 .\end{array}$ \\
\hline 1998 & $\begin{array}{l}\text { AGUILERA, Sandra Mara. A influência africana na língua portuguesa. } \\
\text { In: LIMA, Ivan Costa; ROMÃO, Jeruse; SILVEIRA, Sônia Maria } \\
\text { (Org.). Os negros, os conteúdos escolares e a diversidade cultural. } \\
\text { Florianópolis: Núcleo de Estudos Negros (NEN), 1998, v. 3, p. 15-29. } \\
\text { (Série Pensamento Negro em Educação). }\end{array}$ \\
\hline 1998 & $\begin{array}{l}\text { ALKMIM, Tânia Maria. Português de negros e escravos: atitudes e } \\
\text { preconceitos históricos. Estudos Portugueses e Africanos, Campinas, } \\
\text { v. 31, p. 39-47, 1998. }\end{array}$ \\
\hline 1998 & $\begin{array}{l}\text { CASTRO, Yeda Pessoa. O Ensino de Línguas Africanas no Brasil. In: } \\
\text { LIMA, Ivan Costa; ROMÃO, Jeruse; SILVEIRA, Sônia Maria (Org.). } \\
\text { Os Negros, os Conteúdos Escolares e a Diversidade Cultural. } \\
\text { Florianópolis: Núcleo de Estudos Negros - NEN, 1998, p. 29-38. }\end{array}$ \\
\hline 1998 & $\begin{array}{l}\text { CUNHA, Ana Stela de Almeida. Estruturas Tópicas na fala de duas } \\
\text { comunidades negras rurais do Maranhão. Cadernos Teses Em } \\
\text { Andamento, Campinas, v. } 2 \text {, p. } 36-39,1998 .\end{array}$ \\
\hline 1998 & $\begin{array}{l}\text { MELLO, Heliana Ribeiro de; BAXTER, Alan; HOLM, John; } \\
\text { MEGENNEY, W. Português Vernáculo do Brasil. In: PERL, Matthias; }\end{array}$ \\
\hline
\end{tabular}




\begin{tabular}{|c|c|}
\hline & $\begin{array}{l}\text { SCHWEGLER, Armin Schwegler. (Org.). America negra: panoramica } \\
\text { actual de los estudios linguisticos sobre variedades hispanas, } \\
\text { portuguesas y criollas. } 1^{\text {a }} \text { ed. Frankfurt: Vervuert, v. 1, p. 71-137, } \\
1998 .\end{array}$ \\
\hline 1998 & $\begin{array}{l}\text { PETTER, Maria Margarida Taddoni. Línguas especiais, línguas } \\
\text { secretas: na África e no Brasil. Revista da ANPOLL, São Paulo, v. 4, p. } \\
\text { 185-202, } 1998 \text {. }\end{array}$ \\
\hline 1998 & $\begin{array}{l}\text { PETTER, Maria Margarida Taddoni. A presença de línguas africanas } \\
\text { no português do Brasil. Estudos Lingüísticos (São Paulo), São José do } \\
\text { Rio Preto, v. XXVII, p. 777-783, } 1998 \text {. }\end{array}$ \\
\hline 1998 & $\begin{array}{l}\text { QUEIROZ, Sônia. Pé Preto no Barro Branco: a Língua dos Negros da } \\
\text { Tabatinga. Belo Horizonte: UFMG, } 1998 \text {. }\end{array}$ \\
\hline 1999 & $\begin{array}{l}\text { BAXTER, Alan; LUCCHESI, Dante. Un paso más hacia la definición } \\
\text { del pasado criollo del dialecto afro-brasileño de Helvécia (Bahia). In: } \\
\text { ZIMMERMANN, Klaus (Ed.). Lenguas criollas de base lexical } \\
\text { española y portuguesa. Madri: Iberoamericana, 1999, p.119-141. }\end{array}$ \\
\hline 1999 & $\begin{array}{l}\text { CARENO, Mary Francisca. Traços Sintáticos do Português Popular } \\
\text { Brasileiro usado em Comunidades Negras Rurais. In: } \\
\text { ZIMMERMANN, Klaus (Ed.). (Org.). Lenguas Criollas de Base } \\
\text { Lexical Española y Portuguesa. Berlin-Alemanha: Vervuert, 1999, p. } \\
\text { 503-523. }\end{array}$ \\
\hline 1999 & $\begin{array}{l}\text { CUNHA, Ana Stela de Almeida. Processos de topicalização e } \\
\text { deslocamento à esquerda na fala de duas comunidades negras rurais } \\
\text { do Maranhão. São Paulo, 1999. Dissertação (Mestrado em Linguística) } \\
\text { - Faculdade de Filosofia, Letras e Ciências Humanas, São Paulo. }\end{array}$ \\
\hline 1999 & $\begin{array}{l}\text { CUNHA, Ana Stela de Almeida. Perda de flexão verbal e } \\
\text { preenchimento da categoria sujeito na variedade popular rural do PB } \\
\text { falado nos quilombos do Maranhão. Revista Enapol, São Paulo, } 1999 .\end{array}$ \\
\hline 1999 & $\begin{array}{l}\text { FERREIRA, Graziele de Lourdes Novato. Cinzento: memória de uma } \\
\text { comunidade negra remanescente de quilombo. São Paulo, } 1999 . \\
\text { Dissertação (Mestrado em Ciências Sociais) - Faculdade de Filosofia, } \\
\text { Comunicação, Letras e Artes, Pontifícia Universidade de São Paulo. }\end{array}$ \\
\hline 1999 & HOLM, John; MELLO, Heliana Ribeiro de. Restructured Portuguese: \\
\hline
\end{tabular}




\begin{tabular}{|c|c|}
\hline & $\begin{array}{l}\text { from Africa to Brazil. In: HUBER, Magnus; PARKVALL, Mikael. } \\
\text { (Org.). Spreading the word. } 1^{\text {a }} \text { ed. Londres: Westminster University } \\
\text { Press, } 1999 \text {, v. 1, p. } 165-176 .\end{array}$ \\
\hline 1999 & $\begin{array}{l}\text { HOLM, John; LORENZINO, Gerardo; MELLO, Heliana. Ribeiro de. } \\
\text { Grados de estruturación: El Español Del Caribe Y El Portugues } \\
\text { Vernáculo Brasileño. In: ORTIZ, José (Org.). Homenaje a Manuel } \\
\text { Alvarez Nazario. } 1^{\text {a }} \text { ed. Frankfurt: Vervuert, 1999, p. 43-60. }\end{array}$ \\
\hline 1999 & $\begin{array}{l}\text { LUCCHESI, Dante. A questão da formação do português popular do } \\
\text { Brasil. A cor das letras, n 3, p. 73-100, } 1999 .\end{array}$ \\
\hline 1999 & $\begin{array}{l}\text { LUCCHESI, Dante. A variação na concordância de gênero em dialetos } \\
\text { despidginizantes e descrioulizantes do português do Brasil. In: Klaus } \\
\text { Zimmermann. (Org.). Lenguas criollas de base lexical española y } \\
\text { portuguesa. Madrid: Ibero-Americana, 1999, p. 477-502. }\end{array}$ \\
\hline 1999 & $\begin{array}{l}\text { MELLO, Heliana Ribeiro de. The genesis and development of } \\
\text { Brazilian vernacular Portuguese. Estocolmo: The Creolist Archives } \\
\text { (Universitet Stockholms), } 1999 .\end{array}$ \\
\hline 1999 & 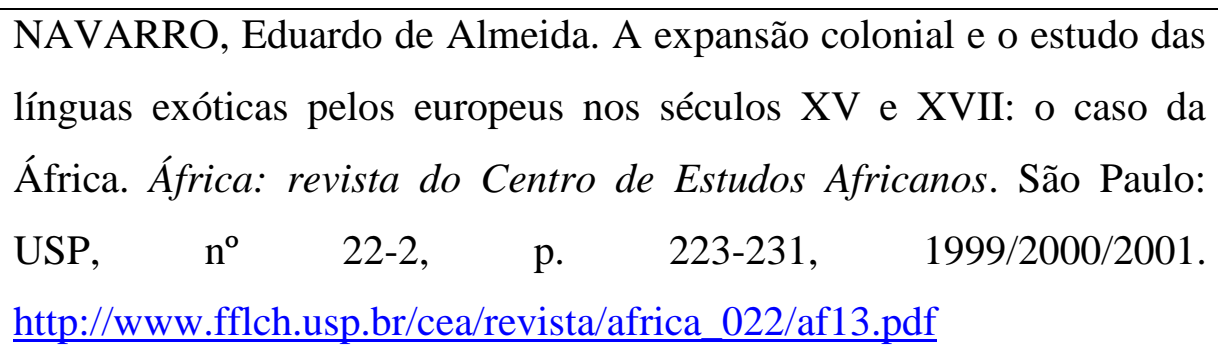 \\
\hline 1999 & $\begin{array}{l}\text { PETTER, Maria Margarida Taddoni. A linguagem do Cafundó: crioulo } \\
\text { ou anticrioulo?. In: ZIMMERMAN, Klaus. (Org.). Lenguas criollas de } \\
\text { base lexical española y portuguesa. Vervuert: Iberoamericana, v. 1, p. } \\
\text { 101-118, } 1999 .\end{array}$ \\
\hline 2000 & $\begin{array}{l}\text { ANDRADE FILHO, Sílvio Vieira de. Um estudo sociolingüístico das } \\
\text { comunidades negras do Cafundó, Caxambu e de seus arredores. } \\
\text { Sorocaba: Prefeitura Municipal, Secretaria da Educação e Cultura de } \\
\text { Sorocaba, } 2000 \text {. }\end{array}$ \\
\hline 2000 & $\begin{array}{l}\text { CUNHA, Ana Stela de Almeida. O português falado em comunidades } \\
\text { remanescentes de quilombos no Maranhão: divergências com a norma } \\
\text { culta em relação ao preenchimento da categoria sujeito. Anais do Gel, } \\
\text { Assis, São Paulo, } 2000 \text {. }\end{array}$ \\
\hline
\end{tabular}




\begin{tabular}{|c|c|}
\hline 2000 & $\begin{array}{l}\text { LUCCHESI, Dante. A variação na concordância de gênero em uma } \\
\text { comunidade de fala afro-brasileira: novos elementos sobre a formação } \\
\text { do português popular do Brasil. Rio de Janeiro, 2000. Doutorado } \\
\text { (Tese em Linguística) - Faculdade de Letras, Universidade Federal do } \\
\text { Rio de Janeiro. }\end{array}$ \\
\hline 2000 & $\begin{array}{l}\text { MATTOS e SILVA, Rosa Virgínia. A língua portuguesa em } \\
\text { perspectiva histórica: do português europeu para o português } \\
\text { brasileiro. Estudos Lingüísticos (São Paulo), São Paulo, n. XXIX, p. } \\
\text { 16-32, 2000. }\end{array}$ \\
\hline 2000 & $\begin{array}{l}\text { MATTOS e SILVA, Rosa Virgínia. Uma interpretação para a } \\
\text { generalizada difusão da língua portuguesa em território brasileiro. } \\
\text { Gragoatá (UFF), Niterói, v. 9, p. 11-27, 2000. Publicado também em: } \\
\text { MATTOS e SILVA, Rosa Virgínia. Uma interpretação para a } \\
\text { generalizada difusão da língua portuguesa no Brasil. Revista da } \\
\text { Academia de Letras da Bahia, Salvador, n.45, p. 105-126, 2002. }\end{array}$ \\
\hline 2000 & $\begin{array}{l}\text { NARO, Anthony Julius; SCHERRE, Maria Marta Pereira. } \\
\text { Concordância variável em português: a situação no Brasil e em } \\
\text { Portugal. ABRALIN (Curitiba), Florianópolis, p. 1259-1270, } 2000 \text {. }\end{array}$ \\
\hline 2000 & $\begin{array}{l}\text { PETTER, Maria Margarida Taddoni. Talvez sejam africanismos. } \\
\text { Estudos Lingüísticos (São Paulo), Assis, v. XXIX, p. 713-718, } 2000 .\end{array}$ \\
\hline 2000 & $\begin{array}{l}\text { SOUZA, Antonio Carlos Santana de. A concordância de gênero entre o } \\
\text { sujeito e o predicativo na fala da comunidade quilombola da } \\
\text { Caçandoca. São Paulo, 2000. Dissertação (Mestrado em Lingüística) - } \\
\text { Faculdade de Filosofia, Letras e Ciências Humanas, Universidade de } \\
\text { São Paulo. }\end{array}$ \\
\hline 2000 & $\begin{array}{l}\text { VOGT, Carlos; FRY, Peter. A descoberta do Cafundó e o Kafundó } \\
\text { descoberto. Com Ciência, Campinas, v. 17, } 2000 . \\
\text { Disponível } \\
\text { http://comciencia.br/reportagens/migracoes/migr12.htm }\end{array}$ \\
\hline 2001 & $\begin{array}{l}\text { ALKMIM, Tânia Maria. A variedade linguística de negros e escravos: } \\
\text { um tópico da história do português no Brasil. In: MATTOS E SILVA, } \\
\text { Rosa Virginia. (Org.). Para história do português brasileiro: Volume } \\
\text { II. São Paulo: Humanitas/FFCH-USP, 2001, v. 2, p. 317-335. }\end{array}$ \\
\hline
\end{tabular}




\begin{tabular}{|c|c|}
\hline 2001 & $\begin{array}{l}\text { CASTRO, Yeda Pessoa. Falares Africanos na Bahia (um vocabulário } \\
\text { Afro-Brasileiro). Rio de Janeiro: Topbooks, } 2001 .\end{array}$ \\
\hline 2001 & $\begin{array}{l}\text { CUNHA, Ana Stela de Almeida. Olhar para a África para compreender } \\
\text { o Brasil: a situação lingüística de Angola e o português falado nos } \\
\text { quilombos do Maranhão. Revista Enapol, São Paulo: Humanitas, v. vol } \\
\text { 1, p. 105-110, 2001. }\end{array}$ \\
\hline 2001 & $\begin{array}{l}\text { CUNHA-HENCKEL, Rosa Alice. Bantuísmos lexicais no português } \\
\text { do Brasil com base no estudo da obra de José Lins do Rego. Brema, } \\
\text { 2001. Tese (Doutorado) - Universidade de Brema. }\end{array}$ \\
\hline 2001 & $\begin{array}{l}\text { CUNHA-HENCKEL, Rosa Alice. "Afrika in Brasilien". Tópicos, } \mathrm{n}^{\circ} 2 \text {, } \\
\text { p. } 14-15,2001 .\end{array}$ \\
\hline 2001 & $\begin{array}{l}\text { PETTER, Margarida M. Taddoni. Seriam traços de línguas africanas } \\
\text { no português do Brasil. Estudos Lingüísticos (São Paulo), Marília, v. } \\
\text { XXX, p. } 67-72,2001 \text {. }\end{array}$ \\
\hline 2001 & $\begin{array}{l}\text { PETTER, Margarida Maria Taddoni. Africanismos no Português do } \\
\text { Brasil. In: ORLANDI, Eni. (Org.). História das Idéias Lingüísticas: } \\
\text { Construção do saber metalingüístico e constituição da Língua } \\
\text { Nacional. } 1^{\text {a }} \text { ed. Campinas: Pontes, Cáceres: UNEMAT Editora, p. } \\
223-234,2001 \text {. }\end{array}$ \\
\hline 2001 & $\begin{array}{l}\text { SCHERRE, Maria Marta Pereira; NARO, Anthony Julius. Sobre as } \\
\text { origens estruturais do português brasileiro: crioulização ou mudança } \\
\text { natural? Papia (Brasília), Brasília, v. 11, p. 41-50, 2001. Publicado } \\
\text { também em: Garimpando as origens do Português brasileiro: sobre três } \\
\text { estruturas linguísticas radicais. In: SCHERRE, Maria Marta Pereira; } \\
\text { NARO Anthony Julius (Org.). Origens do Português Brasileiro. São } \\
\text { Paulo: Parábola Editorial, p. } 71-85,2007 \text {. }\end{array}$ \\
\hline 2001 & $\begin{array}{l}\text { UMBELINO DE BARROS, Elizabete. Traços do kimbundu numa } \\
\text { Casa de Candomblé Angola. São Paulo, 2001. Dissertação (Mestrado } \\
\text { em Lingüística) - Faculdade de Filosofia, Letras e Ciências Humanas, } \\
\text { Universidade de São Paulo. }\end{array}$ \\
\hline 2002 & $\begin{array}{l}\text { ALKMIM, Tânia Maria. Estereótipos linguísticos: negros em charges } \\
\text { do século XIX. In: ALKMIM, Tania Maria. (Org.). Para a História do } \\
\text { Português Brasileiro: Volume III. São Paulo: Humanitas, 2002, v. 3, p. }\end{array}$ \\
\hline
\end{tabular}




\begin{tabular}{|c|c|}
\hline & $383-402$. \\
\hline 2002 & $\begin{array}{l}\text { CUNHA-HENCKEL, Rosa Alice. Brasileirismos de origem africana. } \\
\text { In: GROBE, S.; SCHÖNBERGER, A. (Orgs.). Ex oriente lux. } \\
\text { Festschrift Eberhard Gärtner zu seinem 60. Geburtstag. Frankfurt am } \\
\text { Main: Valentia, 2002, p. 89-102. }\end{array}$ \\
\hline 2002 & $\begin{array}{l}\text { HOLM, John; MELLO, Heliana Ribeiro de. Interpretação das origens } \\
\text { do Português Vernáculo Brasileiro à luz de uma análise } \\
\text { sociolinguística de dados demográficos. In: IGLA, Birgit; STOLZ, } \\
\text { Thomas (Eds). Was ich noch sagen wollte... Festschrift für Norbert } \\
\text { Boretzky zum 65. Geburtstag. Berlin: Akademie Verlag, pp. 223-236, } \\
2002 \text {. }\end{array}$ \\
\hline 2002 & $\begin{array}{l}\text { LIMA, Ivana Stolze. As rusgas da identidade. Rio de Janeiro, 1831- } \\
\text { 1833. Acervo (Rio de Janeiro), Rio de Janeiro, v. 15, no 1, p. 23-37, } \\
\text { 2002. }\end{array}$ \\
\hline 2002 & $\begin{array}{l}\text { LUCCHESI, Dante. O português se teria crioulizado no Brasil? - } \\
\text { refletindo sobre uma velha questão. Afrika, Asien, Brasilien, Portugal, } \\
\text { Frankfurt, Alemanha, v. } 2 \text {, p. } 25-43,2002 \text {. }\end{array}$ \\
\hline 2002 & $\begin{array}{l}\text { MATTOS E SILVA, Rosa Virgínia. Uma compreensão histórica do } \\
\text { português brasileiro: velhos problemas revisitados. Conferência para } \\
\text { Concurso Público de Professor Titular. Bahia: UFBA, 1999, } \\
\text { mimeografado. Publicado também em: MATTOS e SILVA, Rosa } \\
\text { Virgínia. Uma compreensão histórica do português brasileiro: velhos } \\
\text { problemas revisitados. Estudos Lingüísticos e Literários, Salvador, n. } \\
\text { 25/26, p. 250-283, 2002. }\end{array}$ \\
\hline 2002 & $\begin{array}{l}\text { MELLO, Heliana Ribeiro de. Português padrão, português não-padrão } \\
\text { e a hipótese do contato lingüístico. In: ALKMIN, Tânia Maria. (Org.). } \\
\text { Para a história do português brasileiro. Novos estudos. São Paulo: } \\
\text { Humanitas, v. III, p. } 341-358,2002 \text {. }\end{array}$ \\
\hline 2002 & $\begin{array}{l}\text { PETTER, Margarida Maria Taddoni; HONÓRIO, Maria Aparecida; } \\
\text { FERREIRA, Mário; NUNES, José Horta. A constituição do léxico } \\
\text { nacional - problemas de línguas em contato. Estudos Lingüísticos (São } \\
\text { Paulo), São Paulo, v. XXXI, p. 106-112, 2002. }\end{array}$ \\
\hline
\end{tabular}




\begin{tabular}{|c|c|}
\hline 2002 & $\begin{array}{l}\text { PETTER, Margarida Maria Taddoni. Termos de origem africana no } \\
\text { léxico do português do Brasil. In: NUNES, José Horta; PETTER, } \\
\text { Margarida. (Org.). História do saber lexical e constituição de um } \\
\text { léxico brasileiro. } 1^{\text {a }} \text { ed. São Paulo: Humanitas/FFLCH/USP; Pontes, } \\
2002 \text {, p. 123-146. }\end{array}$ \\
\hline 2002 & $\begin{array}{l}\text { QUEIROZ, Sônia. Remanescentes culturais africanos no Brasil. } \\
\text { Aletria, p. 28-60, 2002. }\end{array}$ \\
\hline 2003 & $\begin{array}{l}\text { ANDRADE, Patrícia Ribeiro de. Um fragmento da constituição sócio- } \\
\text { histórica do português do Brasil: variação na concordância nominal de } \\
\text { número em um dialeto afro-brasileiro. Salvador, 2003. Dissertação } \\
\text { (Mestrado em Linguística) - Instituto de Letras, Universidade Federal } \\
\text { da Bahia, Salvador. }\end{array}$ \\
\hline 2003 & $\begin{array}{l}\text { BURGOS, Luiz Eduardo Simões de. Estratégias de uso das relativas } \\
\text { em uma comunidade de fala afro-brasileira. 2003. Dissertação } \\
\text { (Mestrado em Letras e Linguística) - Instituto de Letras, Universidade } \\
\text { Federal da Bahia, Salvador. }\end{array}$ \\
\hline 2003 & $\begin{array}{l}\text { CASTRO, Yeda Pessoa. A Diversidade das Línguas Africanas e } \\
\text { Atitudes Linguísticas no Relacionamento Brasil-África. In: } \\
\text { MENEZES, Jaci Maria Ferraz de; CASTRO, Yeda Pessoa; } \\
\text { GONÇALVES, José Manuel. (Org.). Relações do Atlântico Sul: } \\
\text { História e Contemporaneidade. Salvador: Editora UNEB, 2003, p. 35- } \\
\text { 38. }\end{array}$ \\
\hline 2003 & $\begin{array}{l}\text { CASTRO, Yeda Pessoa. Redescobrindo as línguas africanas. In: } \\
\text { CHAVES, Rita; SECCO, Carmen; MACÊDO, Tania. (Org.). } \\
\text { Brasil/África: Como se o mar fosse mentira. Maputo: Imprensa } \\
\text { Universitária - Universidade Eduardo Mondlane, 2003, p. 359-374. }\end{array}$ \\
\hline 2003 & $\begin{array}{l}\text { COELHO, Olga Ferreira. A anguzada lexicográfica luso-bundo- } \\
\text { americana: língua e identidade nacional na segunda metade do século } \\
\text { XIX. São Paulo, 2003. Tese (Doutorado em Linguística Geral) - } \\
\text { Faculdade de Filosofia, Letras e Ciências Humanas. }\end{array}$ \\
\hline 2003 & $\begin{array}{l}\text { CUNHA, Ana Stela de Almeida. A atuação do Parâmetro do Sujeito } \\
\text { Nulo na variedade popular rural do português do Brasil. São Paulo, } \\
\text { 2003. Tese (Doutorado em Linguística) - Faculdade de Filosofia, }\end{array}$ \\
\hline
\end{tabular}




\begin{tabular}{|c|c|}
\hline & Letras e Ciências Humanas, São Paulo. \\
\hline 2003 & $\begin{array}{l}\text { CUNHA, Ana Stela de Almeida. Mudança paramétrica em curso nas } \\
\text { estruturas coordenadas do português falado em terras de preto. Revista } \\
\text { da Abralin, Rio de Janeiro, } 2003 \text {. }\end{array}$ \\
\hline 2003 & $\begin{array}{l}\text { CUNHA, Ana Stela de Almeida. Presença e contribuição das línguas } \\
\text { negro-africanas para a constituição do português do Brasil: a alegada } \\
\text { origem crioula e a variedade popular da língua falada nas terras de } \\
\text { preto. Anais da Abanne, São Luís, Maranhão, } 2003 \text {. }\end{array}$ \\
\hline 2003 & $\begin{array}{l}\text { FERREIRA, Cinthia Carla. A variação do pronome sujeito na fala da } \\
\text { comunidade Kalunga. Brasília, 2003. 102f. Dissertação (Mestrado em } \\
\text { Linguística) - Instituto de Letras, Universidade de Brasília. }\end{array}$ \\
\hline 2003 & $\begin{array}{l}\text { LUCCHESI, Dante. O conceito de transmissão linguística irregular e o } \\
\text { processo de formação do português do Brasil. In: RONCARATI, } \\
\text { Cláudia; ABRAÇADO, Jussara. (Org.). Português Brasileiro: contato } \\
\text { lingüístico, heterogeneidade e história. } 1^{\mathrm{a}} \text { ed. Rio de Janeiro: 7letras, } \\
2003 \text {, p. } 272-284 \text {. }\end{array}$ \\
\hline 2003 & $\begin{array}{l}\text { MATTOS e SILVA, Rosa Virgínia. A gramaticalização numa } \\
\text { perspectiva diacrônica: contribuições baianas. Estudos Lingüísticos e } \\
\text { Literários, Salvador, n. 29/30, p. 135-147, } 2003 \text {. }\end{array}$ \\
\hline 2003 & $\begin{array}{l}\text { NASCIMENTO, Lúcia Valéria do. A África no Serro Frio: vissungos } \\
\text { de Milho Verde e São João da Chapada. 2003. Dissertação (Mestrado } \\
\text { em Lingüística) - Faculdade de Letras, Universidade Federal de Minas } \\
\text { Gerais, Belo Horizonte, } 2003 \text {. }\end{array}$ \\
\hline 2003 & $\begin{array}{l}\text { OLIVEIRA, Klebson. Textos escritos por africanos e afrodescendentes } \\
\text { na Bahia do século XIX: fontes do nosso latim vulgar?. Salvador, } \\
\text { 2003. Dissertação (Mestrado em Letras e Lingüística) - Instituto de } \\
\text { Letras, Universidade Federal da Bahia. }\end{array}$ \\
\hline 2003 & $\begin{array}{l}\text { PETTER, Margarida Maria Taddoni. A fala da comunidade do } \\
\text { Cangume: alguns traços fonéticos específicos. ABRALIN (Curitiba), } \\
\text { Fortaleza, v. 2, p. 359-361, } 2003 \text {. }\end{array}$ \\
\hline 2003 & $\begin{array}{l}\text { SILVA, Deijair Ferreira da. O futuro em Helvécia e em Cinzento: um } \\
\text { estudo do uso das formas simples e perifrásticas no português rural } \\
\text { afro-brasileiro. Salvador, 2003. Dissertação (Mestrado em Letras e }\end{array}$ \\
\hline
\end{tabular}




\begin{tabular}{|c|c|}
\hline & Linguística), Universidade Federal da Bahia. \\
\hline 2003 & $\begin{array}{l}\text { SILVA, Jorge Augusto Alves da. A concordância verbal no português } \\
\text { afro-brasileiro: um estudo sociolinguístico de três comunidades rurais } \\
\text { do Estado da Bahia. Salvador, 2003. Dissertação (Mestrado em } \\
\text { Linguística) - Universidade Federal da Bahia, Salvador. }\end{array}$ \\
\hline 2004 & $\begin{array}{l}\text { ANDRADE, Patrícia Ribeiro de. A concordância nominal de número } \\
\text { no português afro-brasileiro. Revista do GELNE (UFC), João Pessoa, } \\
\text { p. } 2075-2082,2004 \text {. }\end{array}$ \\
\hline 2004 & $\begin{array}{l}\text { CAVALCANTE, Rerisson. Construções negativas no português falado } \\
\text { em Salvador. Hyperion, Salvador, v. 1, p. 12, } 2004 .\end{array}$ \\
\hline 2004 & $\begin{array}{l}\text { CUNHA, Ana Stela de Almeida; BUENO, André. Situações } \\
\text { linguageiras favorecedoras da difusão do português: A África na } \\
\text { Historiografia Linguística Brasileira. Língua, Linguística \& Literatura, } \\
\text { João Pessoa, vol. 2, no 1/2, p. 33-48, 2004/2005. }\end{array}$ \\
\hline 2004 & $\begin{array}{l}\text { FIGUEIREDO, Maria Cristina Vieira de. O objeto direto anafórico no } \\
\text { dialeto rural afrobrasileiro. Salvador, 2004. } 149 \text { Folhas. Dissertação } \\
\text { (Mestrado em Letras e Linguística) - Instituto de Letras, Universidade } \\
\text { Federal da Bahia. }\end{array}$ \\
\hline 2004 & $\begin{array}{l}\text { FRANÇA, Nilcéia Albuquerque. Origens do Português no Brasil: Da } \\
\text { crioulização ao Português brasileiro. Revista de História Regional, v. } \\
7,2004 \text {, p. } 164-171 \text {. }\end{array}$ \\
\hline 2004 & $\begin{array}{l}\text { LIMA, Ivana Stolze. A língua brasileira e os sentidos de nacionalidade } \\
\text { e mestiçagem no Império do Brasil. Topoi. Revista de História, Rio de } \\
\text { Janeiro, v. 7, dez. } 2003 \text {, p. 334-356, } 2004 \text {. }\end{array}$ \\
\hline 2004 & $\begin{array}{l}\text { LOBO, Tânia Conceição Freire; RIBEIRO, Ilza. A concordância de } \\
\text { número entre verbo e sujeito em textos escritos por negro forro na } \\
\text { Bahia do século XIX. Filologia e Lingüística Portuguesa, São Paulo, } \\
\text { v. 6, p. 199-220, 2004. Publicado também em: A concordância de } \\
\text { número entre verbo e sujeito em textos escritos por negro forro na } \\
\text { Bahia do século XIX. In: COSTA, Sônia Bastos Borba; MACHADO } \\
\text { FILHO, Américo Venâncio Lopes. (Org.). Do português arcaico ao } \\
\text { português brasileiro. Salvador: EDUFBA, 2004, p. 67-82. }\end{array}$ \\
\hline
\end{tabular}




\begin{tabular}{|c|c|}
\hline 2004 & $\begin{array}{l}\text { MATTOS e SILVA, Rosa Virgínia. O português no Brasil: sua } \\
\text { formação na complexidade multilingüística do Brasil colonial e pós- } \\
\text { colonial. Leituras Contemporâneas. Salvador, v. 1, n.1, p. 95-105, } \\
\text { 2004. Publicado também: O português brasileiro: sua formação na } \\
\text { complexidade multilingüística do Brasil colonial e pós-colonial. In: } \\
\text { COSTA, Sônia; MACHADO FILHO, Américo. (Org.). Do português } \\
\text { arcaico ao português brasileiro. Salvador: Edufba, 2004, p. 115-137. }\end{array}$ \\
\hline 2004 & $\begin{array}{l}\text { MATTOS e SILVA, Rosa Virgínia; MACHADO FILHO, Américo } \\
\text { Venâncio Lopes. A variação ter/haver na primeira metade do século } \\
\text { XIX em textos escritos por africanos e afro-descendentes. Lingüistica } \\
\text { (Madrid), São Paulo, v. } 15-16, \text { p. } 161-174,2004 \text {. }\end{array}$ \\
\hline 2004 & $\begin{array}{l}\text { PETTER, Margarida Maria Taddoni. Contact des langues au Brésil: les } \\
\text { langues africaines et le portugais brésilien. In: AKINBIYI, Akindabi; } \\
\text { OLUSEYE, Adesola. (Org.). Proceedings of the 4th World Congress } \\
\text { of African Linguistics - New Brunswick 2003. Hamburgo: Rüdiger } \\
\text { Köppe Verlag, v. 1, p. 234-245, } 2004 \text {. }\end{array}$ \\
\hline 2005 & $\begin{array}{l}\text { ALMEIDA, Alessandra Preussler. A concordância verbal na } \\
\text { comunidade de São Miguel dos Pretos, Restinga Seca, RS. Porto } \\
\text { Alegre, 2005. Dissertação (Mestrado em Estudos da Linguagem) - } \\
\text { Instituto de Letras, Universidade Federal do Rio Grande do Sul. }\end{array}$ \\
\hline 2005 & $\begin{array}{l}\text { ALMEIDA, Norma Lucia Fernandes de. Sujeito nulo e morfologia } \\
\text { verbal no português falado por três comunidades do interior da Bahia. } \\
\text { Campinas, 2005. Tese (Doutorado em Linguística) - Instituto de } \\
\text { Estudos da Linguagem, Universidade Estadual de Campinas. }\end{array}$ \\
\hline 2005 & $\begin{array}{l}\text { CASTRO, Yeda Pessoa. A influência das línguas africanas no } \\
\text { português brasileiro. In: Secretaria Municipal de Educação - Prefeitura } \\
\text { da Cidade do Salvador. (Org.). Pasta de textos da professora e do } \\
\text { professor. Salvador: Secretaria Municipal de Educação, } 2005 \text {. }\end{array}$ \\
\hline 2005 & $\begin{array}{l}\text { LUCCHESI, Dante. Reanálise da variação na concordância de gênero } \\
\text { em um dialeto afro-brasileiro. Revista do GELNE (UFC), Fortaleza, v. } \\
3 \text {, n.2, p. } 27-30,2005 \text {. }\end{array}$ \\
\hline 2005 & $\begin{array}{l}\text { LUCCHESI, Dante. A participação do contato entre línguas na } \\
\text { formação do português popular do Brasil: Novas evidências empíricas. }\end{array}$ \\
\hline
\end{tabular}




\begin{tabular}{|c|c|}
\hline & $\begin{array}{l}\text { In: FERNÁNDEZ, Mauro; FERNÁNDEZ-FERREIRO, Manuel; } \\
\text { VEIGA, Nancy Vázquez. (Org.). Los criollos de base ibérica. } 1^{\mathrm{a}} \text { ed. } \\
\text { Madrid: Iberoamericana, 2005, v. 24, p. 215-226. }\end{array}$ \\
\hline 2005 & $\begin{array}{l}\text { LUCCHESI, Dante. Contato entre línguas e variação paramétrica: o } \\
\text { sujeito nulo no português afro-brasileiro. Lingua(gem), Macapá- } \\
\text { Amapá, v. } 1, \mathrm{n}^{\circ} \text { 2, p. } 63-91,2005 \text {. }\end{array}$ \\
\hline 2005 & $\begin{array}{l}\text { OLIVEIRA, Klebson. O lugar do branco na escrita de negros: notas } \\
\text { sobre segmentação gráfica em textos de africanos e afrodescendentes } \\
\text { no Brasil do século XIX. Revista Internacional de Lingüística } \\
\text { Iberoamericana, Berlim/Madrid, v. 1, p. 153-170, } 2005 \text {. }\end{array}$ \\
\hline 2005 & $\begin{array}{l}\text { PAL, Dayane Cristina. "Aí fui inu, fui inu, aí peguei arrumei uma casa } \\
\text { no capoava lá". Construções seriais em português brasileiro: estudo } \\
\text { com dados da comunidade negra de Pedro Cubas, Vale do Ribeira/SP. } \\
\text { São Paulo, 2005. Dissertação (Mestrado em Linguística) - Faculdade } \\
\text { de Filosofia, Letras e Ciências Humanas, Universidade de São Paulo. }\end{array}$ \\
\hline 2005 & $\begin{array}{l}\text { PETTER, Margarida Maria Taddoni. Línguas africanas no Brasil. } \\
\text { Gragoatá, Rio de Janeiro, v. 19, p. 193-227, } 2005 .\end{array}$ \\
\hline 2005 & $\begin{array}{l}\text { PETTER, Margarida Maria Taddoni; ZANONI, Dafne. Quilombos do } \\
\text { Vale do Ribeira: variação e mudança na concordância de gênero e de } \\
\text { número. Papia, Brasília, v. } 15 \text {, p. } 61-71,2005 \text {. }\end{array}$ \\
\hline 2005 & $\begin{array}{l}\text { UMBELINO DE BARROS, Elizabete. Traços de Quimbundo em uma } \\
\text { comunidade religiosa. Papia (Brasília), v. 15, p. 116-120, } 2005 .\end{array}$ \\
\hline 2005 & $\begin{array}{l}\text { VIARO, Mário Eduardo. Palavras africanas... será?. Discutindo } \\
\text { Língua Portuguesa, v. 1, p. 58-60, } 2005 .\end{array}$ \\
\hline 2005 & $\begin{array}{l}\text { VOGT, Carlos; FRY, Peter. As formas de expressão na Língua } \\
\text { Africana do Cafundó. Ciência e Cultura (SBPC), São Paulo/Campinas, } \\
\text { v. } 57, \mathrm{n}^{\circ} \text { 2, p. } 39-42,2005 \text {. }\end{array}$ \\
\hline 2005 & $\begin{array}{l}\text { XAVIER, Francisco. Adaptação fonológica dos empréstimos do } \\
\text { quimbundo no português brasileiro: abordagem em teoria da } \\
\text { otimidade. São Paulo, 2005. Dissertação (Mestrado em Linguística) - } \\
\text { Faculdade de Filosofia, Letras e Ciências Humanas, Universidade de } \\
\text { São Paulo. }\end{array}$ \\
\hline 2006 & ALKMIM, Tânia Maria. Fala de escravos brasileiros e portugueses: \\
\hline
\end{tabular}




\begin{tabular}{|c|c|}
\hline & $\begin{array}{l}\text { um esboço de comparação. In: LOBO, Tânia; RIBEIRO, Ilza; } \\
\text { CARNEIRO, Zenaide; ALMEIDA, Norma (Org.). Para a história do } \\
\text { português brasileiro: Volume IV: Novos dados, novas análises. } \\
\text { Salvador/BA: EDUFBA, 2006, v. II, p. 585-594. }\end{array}$ \\
\hline 2006 & $\begin{array}{l}\text { ALKMIM, Tânia Maria. A fala como marca: escravos nos anúncios de } \\
\text { Gilberto Freire. Scripta (PUCMG), v. 9, p. 221-229, } 2006 .\end{array}$ \\
\hline 2006 & $\begin{array}{l}\text { BAXTER, Alan; LOPES, Norma. Bare definite reference NPs in an } \\
\text { Afro-Brazilian Portuguese dialect. Revista Internacional de Lingüística } \\
\text { Iberoamericana, Madrid, v.4, n.1, p.55-70, } 2006 \text {. }\end{array}$ \\
\hline 2006 & $\begin{array}{l}\text { CARVALHO, Guilhermina Maria Bastos Mendes de. A } \\
\text { inacusatividade na fala de comunidades rurais afro-brasileiras } \\
\text { isoladas. Salvador, 2006. Dissertação (Mestrado em Letras e } \\
\text { Linguística) - Universidade Federal da Bahia. }\end{array}$ \\
\hline 2006 & $\begin{array}{l}\text { CASTRO, Yeda Pessoa. O Português e as línguas africanas no Brasil } \\
\text { colonial. In: SCHRADER-KNIFFKI, Martina; MORGENTHALER, } \\
\text { Laura García. (Org.). Romania en interacción: Entre historia, contacto } \\
\text { y política. Ensayos en homenaje a Klaus Zimmermann. Frankfurt/ } \\
\text { Madrid: Vervuert/ Iberoamericana, 2007, p. 361-379. Ver também em: } \\
\text { CASTRO, Yeda Pessoa. Redescobrindo as línguas africanas. In: } \\
\text { CHAVES, Rita, SECCO, Carmen; MACEDO, Tânia. (Org.). Luanda: } \\
\text { Chá de Caxinde. São Paulo: UNESP, 2006, p. 361-376. }\end{array}$ \\
\hline 2006 & $\begin{array}{l}\text { CASTRO, Yeda Pessoa de. A matriz africana no português do Brasil. } \\
\text { In: CARDOSO, Suzana Alice; MOTA, Jacyra; SILVA, Rosa Virgínia } \\
\text { Mattos (Org.). Quinhentos anos de história lingüística do Brasil. } \\
\text { Salvador: Secretaria de Cultura e Turismo do Estado da Bahia, 2006. p. } \\
\text { 81-116. }\end{array}$ \\
\hline 2006 & $\begin{array}{l}\text { CÔRTES JUNIOR, Moacir da Silva. As sentenças clivadas: um estudo } \\
\text { de suas realizações estruturais no português rural afro-brasileiro. } \\
\text { Revista do GELNE (UFC), v. 221, p. 2212-2221, } 2006 \text {. }\end{array}$ \\
\hline 2006 & $\begin{array}{l}\text { CÔRTES JUNIOR, Moacir da Silva. Clivadas e Pseudo-clivadas: um } \\
\text { estudo de suas realizações estruturais no português rural afro- } \\
\text { brasileiro. Salvador, 2006. Dissertação (Mestrado em Letras e } \\
\text { Linguística) - Universidade Federal da Bahia. }\end{array}$ \\
\hline
\end{tabular}




\begin{tabular}{|c|c|}
\hline 2006 & $\begin{array}{l}\text { CUNHA-HENCKEL, Rosa Alice. "Bantuísmos lexicais no português } \\
\text { do século XVIII". In: THIELEMANN, Werner (Ed.). Século das Luzes } \\
\text { - Portugal e Espanha, o Brasil e a Região do Rio da Prata. Frankfurt } \\
\text { am Main: TFM, 2006. }\end{array}$ \\
\hline 2006 & $\begin{array}{l}\text { FIGUEIREDO, Maria Cristina Vieira de. O objeto direto anafórico no } \\
\text { dialeto rural afro-brasileiro do estado da Bahia. Estudos (UFBA), v. } \\
33 / 34 \text {, p. } 45-67,2006 \text {. }\end{array}$ \\
\hline 2006 & $\begin{array}{l}\text { FIGUEIREDO, Maria Cristina Vieira de. O objeto direto anafórico no } \\
\text { dialeto rural afro-brasileiro do estado da Bahia - versão preliminar. } \\
\text { Inventário (UFBA), v. } 5,2006 \text {. }\end{array}$ \\
\hline 2006 & $\begin{array}{l}\text { LIMA, Ivana Stolze. Línguas malditas. Revista de História da } \\
\text { Biblioteca Nacional, n. 9, abril de } 2006 \text {. }\end{array}$ \\
\hline 2006 & $\begin{array}{l}\text { LUCCHESI, Dante; BAXTER, Alan. Processos de crioulização na } \\
\text { história sociolingüística do Brasil. In: CARDOSO, Suzana; MOTA, } \\
\text { Jacyra; MATTOS E SILVA, Rosa Virgínia. (Org.). Quinhentos Anos } \\
\text { de História Lingüística do Brasil. } 1^{\mathrm{a}} \text { ed. Salvador: Secretaria da } \\
\text { Cultura e Turismo do Estado da Bahia, v. 01, p. 163-218, } 2006 \text {. }\end{array}$ \\
\hline 2006 & $\begin{array}{l}\text { MEIRA, Vivian. O uso do modo subjuntivo em orações relativas e } \\
\text { completivas no português afrobrasileiro. 2006. Dissertação (Mestrado } \\
\text { em Letras e Linguística) - Universidade Federal da Bahia, Salvador. }\end{array}$ \\
\hline 2006 & $\begin{array}{l}\text { OLIVEIRA, Klebson. Negros e escrita no Brasil do século XIX: sócio- } \\
\text { história, edição filológica de documentos e estudo lingüístico. } \\
\text { Salvador, 2006. Tese (Doutorado em Letras e Linguística) - Instituto } \\
\text { de Letras, Universidade Federal da Bahia. }\end{array}$ \\
\hline 2006 & $\begin{array}{l}\text { OLIVEIRA, Klebson. Aquisição da escrita em textos de africanos e } \\
\text { afrodescendentes no Brasil do século XIX: grafias para sílabas } \\
\text { complexas, por exemplo. In: LOBO, Tânia; RIBEIRO, Ilza; } \\
\text { CARNEIRO, Zenaide; ALMEIDA, Norma. (Org.). Para a história do } \\
\text { português brasileiro. Volume VI: novos dados, novas análises. } \\
\text { Salvador: EDUFBA, v. I, p. 469-494, } 2006 \text {. }\end{array}$ \\
\hline 2006 & $\begin{array}{l}\text { OLIVEIRA, Marilza. PB do século XIX: uma Brasiláfrica lingüística?. } \\
\text { In: LOBO, Tânia; RIBEIRO, Ilza; CARNEIRO, Zenaide, ALMEIDA, } \\
\text { Norma. (Org.). Para a História do Português Brasileiro. Salvador: }\end{array}$ \\
\hline
\end{tabular}




\begin{tabular}{|c|c|}
\hline & UFBA, 2006, p. \\
\hline 2006 & $\begin{array}{l}\text { PETTER, Margarida Maria Taddoni. Línguas Africanas no Brasil. In: } \\
\text { CARDOSO, Suzana Alice Marcelino; MOTA, Jacyra Andrade; } \\
\text { MATTOS E SILVA Rosa Virgínia. (Org.). Quinhentos Anos de } \\
\text { História Lingüística do Brasil. Salvador: Secretaria da Cultura e } \\
\text { Turismo do Estado da Bahia, p. 117-142, 2006. }\end{array}$ \\
\hline 2006 & $\begin{array}{l}\text { QUEIROZ, Sônia. Palavra africana em Minas Gerais. In: SEABRA, } \\
\text { Maria Cândida Trindade Costa de. (Org.). Léxico em estudo. Belo } \\
\text { Horizonte: Faculdade de Letras da UFMG, v. 1, p. 59-74, } 2006 .\end{array}$ \\
\hline 2006 & $\begin{array}{l}\text { RIBEIRO, Ilza; FIGUEIREDO, Cristina. As sentenças relativas em } \\
\text { Atas escritas por africanos, no Brasil oitocentista (1832-1842). } \\
\text { Salvador, 2006. Ms. }\end{array}$ \\
\hline 2006 & $\begin{array}{l}\text { SILVA, Jorge Augusto Alves da. A concordância verbal de terceira } \\
\text { pessoa do plural no português popular do Brasil: um panorama } \\
\text { sociolingüístico de três comunidades do interior do estado da Bahia. } \\
\text { Salvador, 2006. Tese (Doutorado em Linguística) - Universidade } \\
\text { Federal da Bahia, Salvador. }\end{array}$ \\
\hline 2006 & $\begin{array}{l}\text { SILVA, Maria Eunice Rosa de Jesus. Rememorando a Chapada } \\
\text { Diamantina: Histórias do Mulungu. Salvador, 2006. Dissertação } \\
\text { (Mestrado em Educação e Contemporaneidade) - Universidade do } \\
\text { Estado da Bahia. }\end{array}$ \\
\hline 2007 & $\begin{array}{l}\text { CASTRO, Yeda Pessoa. Línguas africanas e o português do Brasil. } \\
\text { İrohin, v. } 17 \text {, p. } 32-33,2007 .\end{array}$ \\
\hline 2007 & $\begin{array}{l}\text { CAVALCANTE, Rerisson. A negação pós-verbal no português } \\
\text { brasileiro: análise descritiva e teórica de dialetos rurais de } \\
\text { afrodescendentes. Salvador, 2007. Dissertação (Mestrado em Letras) - } \\
\text { Instituto de Letras, Universidade Federal da Bahia. }\end{array}$ \\
\hline 2007 & $\begin{array}{l}\text { CUNHA-HENCKEL, Rosa Alice. "Africanismos e brasileirismos } \\
\text { lexicais de matriz africana na imprensa brasileira". Martius-Staden- } \\
\text { Jahrbuch, São Paulo, no 54, p. 65-77, } 2007 \text {. }\end{array}$ \\
\hline 2007 & $\begin{array}{l}\text { LIMA, Ivana Stolze. Entre a língua nacional e a fala caçanje. } \\
\text { Representações sociais sobre a língua no Rio de Janeiro. In: COSTA, } \\
\text { Wilma Peres; OLIVEIRA, Cecília Helena de Salles. (Org.). De um }\end{array}$ \\
\hline
\end{tabular}




\begin{tabular}{|c|c|}
\hline & $\begin{array}{l}\text { império a outro. Formação do Brasil, séculos XVIII e XIX. São Paulo: } \\
\text { HUCITEC/FAPESP, p. 63-98, } 2007 .\end{array}$ \\
\hline 2007 & $\begin{array}{l}\text { LUCCHESI, Dante. Alterações no quadro dos pronomes pessoais e na } \\
\text { aplicação da regra de concordância verbal nas normas culta e popular } \\
\text { como evidências da polarização sociolingüística do Brasil e da } \\
\text { relevância histórica do contato entre línguas. Lingüistica. Madrid, v. } \\
\text { 19, p. 52-87, } 2007 \text {. }\end{array}$ \\
\hline 2007 & $\begin{array}{l}\text { MEIRA, Vívian. O uso do subjuntivo nas orações relativas e } \\
\text { completivas no português afro-brasileiro. Gragoatá }(U F F) \text {, v. 21, } \\
2007 \text {. }\end{array}$ \\
\hline 2007 & $\begin{array}{l}\text { MEIRA, Vívian. O uso do modo subjuntivo em orações relativas, } \\
\text { completivas e adverbiais no português afro-brasileiro. Estudos } \\
\text { Linguísticos (São Paulo), v. XXXVI, p. 409-418, } 2007 \text {. }\end{array}$ \\
\hline 2007 & $\begin{array}{l}\text { MEIRA, Vívian. O uso do modo subjuntivo em comunidades rurais } \\
\text { afro-brasileiras. Revista da ABRALIN, v. 6, } 2007 .\end{array}$ \\
\hline 2007 & $\begin{array}{l}\text { NARO, Anthony Julius; SCHERRE, Maria Marta Pereira. O conceito } \\
\text { de transmissão lingüística irregular e as origens estruturais do } \\
\text { português brasileiro: um tema em debate. In: RONCARATI, Cláudia; } \\
\text { ABRAÇADO, Jussara. (Org.). Português brasileiro - contato } \\
\text { lingüístico, heterogeneidade e história. Rio de Janeiro: Viveiros de } \\
\text { Castro Editora, p. 285-382, 2003. Publicado também em O conceito de } \\
\text { transmissão linguística irregular e as origens estruturais do Português } \\
\text { brasileiro. In: NARO, Anthony Julius; SCHERRE, Maria Marta } \\
\text { Pereira. Origens do português brasileiro. São Paulo: Parábola, p.135- } \\
\text { 159, 2007. }\end{array}$ \\
\hline 2007 & $\begin{array}{l}\text { NARO, Anthony Julius; SCHERRE, Maria Marta Pereira. Variable } \\
\text { concord in Portuguese: the situation in Brazil and Portugal. In: } \\
\text { MCWHORTER, John. (Org.). Language change and language contact } \\
\text { in pidgins and creoles. Amsterdam/Philadelphia: John Benjamins, v. } \\
\text { 21, p. 235-255, 2000. Publicado também em: Concordância Variável } \\
\text { em Português: a situação no Brasil e em Portugual. In: Naro, Anthony } \\
\text { Julius; SCHERRE, Maria Marta Perreira. Origens do Português }\end{array}$ \\
\hline
\end{tabular}




\begin{tabular}{|c|c|}
\hline & Brasileiro. São Paulo: Parábola Editorial, p. 49-69, 2007. \\
\hline 2007 & $\begin{array}{l}\text { NARO, Anthony Julius; SCHERRE, Maria Marta Pereira. Origens do } \\
\text { Português Brasileiro. DELTA. Documentação de Estudos em } \\
\text { Lingüística Teórica e Aplicada, São Paulo, v. 9, p. 437-454, } 1993 . \\
\text { Publicado também em Sobre as origens do português popular do } \\
\text { Brasil. In: Naro, Anthony Julius; SCHERRE, Maria Marta Perreira. } \\
\text { Origens do Português Brasileiro. São Paulo: Parábola Editorial, p. 25- } \\
\text { 48, } 2007 \text {. }\end{array}$ \\
\hline 2007 & $\begin{array}{l}\text { NARO, Anthony Julius; SCHERRE, Maria Marta Pereira. } \\
\text { Preenchimento do sujeito pronominal e concordância variável no } \\
\text { português brasileiro. Origens do português brasileiro. São Paulo: } \\
\text { Parábola, p.161-177, 2007. }\end{array}$ \\
\hline 2007 & $\begin{array}{l}\text { NARO, Anthony Julius. Conclusão. Origens do português brasileiro. } \\
\text { São Paulo: Parábola, p.161-177, } 2007 \text {. }\end{array}$ \\
\hline 2007 & $\begin{array}{l}\text { OLIVEIRA, Klebson. A escrita que mascara e desmascara: alteamento } \\
\text { de vogais átonas em textos brasileiros oitocentistas. Interdisciplinar - } \\
\text { Revista de Estudos de Língua e Literatura, v. 4, p. 44-57, } 2007 .\end{array}$ \\
\hline 2007 & $\begin{array}{l}\text { PAGOTTO, Emilio. "Crioulo sim, crioulo não: uma agenda de } \\
\text { problemas". In: CASTILHO, Ataliba T. de; LOPES, Ruth E. } \\
\text { Vasconcellos; TORRES MORAIS, Maria Aparecida; CYRINO, Sônia } \\
\text { Maria Lazzarini. (Org.). Português Brasileiro: Descrição, História e } \\
\text { Aquisição. 1a. ed. Campinas: Pontes, 2007, v. 1, p. 461-482. }\end{array}$ \\
\hline 2007 & $\begin{array}{l}\text { PETTER, Margarida Maria Taddoni. Revista Ilustrada: un document } \\
\text { sur le langage des Noirs à la fin du XIXe siècle. In: GUIMARÃES, } \\
\text { Eduardo; BARROS, Diana Luz Pessoa de. (Org.). History of } \\
\text { Linguistics 2002: selected papers from the Ninth International } \\
\text { Conference on the History of the Language Sciences, 27-30, 2002, São } \\
\text { Paulo, Campinas. Amsterdam: John Benjamins, v. 110, p. 87-92, } 2007 . \\
\text { Disponível } \\
\text { http://www.fflch.usp.br/dl/gela/textos/revista\%20ilustrada.pdf Acesso } \\
\text { em: } 24 / 03 / 2012\end{array}$ \\
\hline 2007 & $\begin{array}{l}\text { ROCHA DA SILVA, Claudia. Variação linguística e leitura de } \\
\text { quilombolas na Bahia: o caso de Barra do Brumado. In: OLIVEIRA, }\end{array}$ \\
\hline
\end{tabular}




\begin{tabular}{|c|c|}
\hline & $\begin{array}{l}\text { Iolanda de; AGUIAR, Márcia Ângela da Silva; SILVA, Petronilha } \\
\text { Beatriz; OLIVEIRA, Raquel de. (Org.). Negro e educação 4: } \\
\text { linguagens, resistências e políticas públicas. SÃO PAULO: ANPED; } \\
\text { AÇÃO EDUCATIVA, } 2007 .\end{array}$ \\
\hline 2007 & $\begin{array}{l}\text { SCHERRE, Maria Marta Pereira; NARO, Anthony Julius. Ampliando } \\
\text { os horizontes do debate sobre as origens da concordância variável no } \\
\text { Português Brasileiro. Origens do Português Brasileiro. São Paulo: } \\
\text { Parábola Editorial, p. 87-116, } 2007 \text {. }\end{array}$ \\
\hline 2008 & $\begin{array}{l}\text { ALKMIM, Tânia Maria. Falas e cores: um estudo sobre o português de } \\
\text { negros e escravos no Brasil do século XIX. In: CARMO, Laura do; } \\
\text { LIMA, Ivana Stolze. (Org.). História social da língua nacional. Rio de } \\
\text { Janeiro: Casa de Rui Barbosa, 2008, p. 247-264. Disponível em } \\
\text { http://www.coresmarcasefalas.pro.br/adm/anexos/11122008002308.pd } \\
\text { f Acesso em: 31/10/2013. }\end{array}$ \\
\hline 2008 & $\begin{array}{l}\text { ALKMIM, Tânia Maria; PETTER, Margarida Maria Taddoni. Palavras } \\
\text { da África no Brasil de ontem e de hoje. In: FIORIN, José Luiz; } \\
\text { PETTER, Margarida Maria Taddoni (Org.). África no Brasil: a } \\
\text { formação da língua portuguesa. São Paulo: Contexto, 2008, p. 145- } \\
179 \text {. }\end{array}$ \\
\hline 2008 & $\begin{array}{l}\text { AVELAR, Juanito Ornelas; CYRINO, Sônia. Locativos } \\
\text { preposicionados em posição de sujeito: uma possível contribuição das } \\
\text { línguas Bantu à sintaxe do português brasileiro. Revista de Estudos } \\
\text { Linguísticos da Universidade do Porto, Porto, v.3, p. 54-75, } 2008 \text {. }\end{array}$ \\
\hline 2008 & $\begin{array}{l}\text { CASTRO, Yeda Pessoa. African Languages and Brazilian Portuguese: } \\
\text { a new approach. In: PETTER, Margarida Maria Taddoni; MENDES, } \\
\text { Ronald Beline (Org.). Proceedings of the Special World Congress of } \\
\text { African Linguistics. São Paulo: Humanitas, p. 47-56, } 2008 \text {. }\end{array}$ \\
\hline 2008 & $\begin{array}{l}\text { CASTRO, Yeda Pessoa. A participação das línguas africanas na } \\
\text { construção do português do Brasil. KILOMBO Revue Annueile } \\
\text { Pluridisciplinaire } d u \text { CERAFIA, v. 04, p. 61-68, } 2008 \text {. }\end{array}$ \\
\hline 2008 & $\begin{array}{l}\text { CASTRO, Yeda Pessoa. Towards a Comparative Approach of } \\
\text { Bantuisms in Iberoamerica. In: PHAF-RHEINBERGER, Ineke; } \\
\text { PINTO, Tiago de Oliveira. (Org.). AfricAmericas: Itineraries, }\end{array}$ \\
\hline
\end{tabular}




\begin{tabular}{|c|c|}
\hline & $\begin{array}{l}\text { Dialogues, and Sounds. Madrid / Frankfurt am Main: Iberoamericana- } \\
\text { Vervuert, v. 119, p. 81-92, } 2008 \text {. }\end{array}$ \\
\hline 2008 & $\begin{array}{l}\text { GALVES, Charlotte. O papel das línguas africanas na formação do } \\
\text { português brasileiro: (mais) pistas para uma nova agenda de pesquisa. } \\
\text { Gragoatá (UFF), v. } 24 \text {, p. } 145-164,2008 \text {. }\end{array}$ \\
\hline 2008 & $\begin{array}{l}\text { LUCCHESI, Dante. A concordância nominal em estruturas passivas e } \\
\text { de predicativo do sujeito em comunidades rurais afro-brasileiras } \\
\text { isoladas no contexto da história sociolingüística do Brasil. In: VOTRE, } \\
\text { Sebastião; RONCARATI, Cláudia. (Org.). Anthony Julius Naro e a } \\
\text { Lingüística no Brasil: uma homenagem acadêmica. } 1^{\mathrm{a}} \text { ed. Rio de } \\
\text { Janeiro: 7Letras, v. } 1 \text {, p. } 148-168,2008 \text {. }\end{array}$ \\
\hline 2008 & $\begin{array}{l}\text { LUCCHESI, Dante. Africanos, crioulos e a língua portuguesa. In: } \\
\text { LIMA, Ivana Stolze; CARMO, Laura do. (Org.). História Social da } \\
\text { Língua Nacional. } 1^{\text {a }} \text { ed. Rio de Janeiro: Casa de Rui Barbosa, v. 1, p. } \\
\text { 151-180, } 2008 .\end{array}$ \\
\hline 2008 & $\begin{array}{l}\text { LUCCHESI, Dante. Aspectos gramaticais do português brasileiro } \\
\text { afetados pelo contato entre línguas: uma visão de conjunto. In: } \\
\text { RONCARATI, Cláudia; ABRAÇADO, Jussara. (Org.). Português } \\
\text { Brasileiro II: contato lingüístico, heterogeneidade e história. } 1^{\text {a }} \text { ed. } \\
\text { Niterói: EdUFF, v. } 2 \text {, p. 366-390, } 2008 \text {. }\end{array}$ \\
\hline 2008 & $\begin{array}{l}\text { MATTOS e SILVA, Rosa Virgínia. Teorias da mudança linguística e a } \\
\text { sua relação com a(s) história(s) da língua(s). Linguística - Revista de } \\
\text { Estudos Linguísticos da Universidade do Porto. Porto, v. 3, p. 39-53, } \\
2008 \text {. }\end{array}$ \\
\hline 2008 & $\begin{array}{l}\text { MELLO, Heliana Ribeiro de. Modelos de formação da língua nacional } \\
\text { sob a perspectiva do contato de populações. In: LIMA, Ivana Stolze; } \\
\text { CARMO, Laura do (Org.). História social da língua nacional. Rio de } \\
\text { Janeiro: Edições Casa de Rui Barbosa, p. } 295-314,2008 \text {. }\end{array}$ \\
\hline 2008 & $\begin{array}{l}\text { NEGRÃO, Esmeralda; VIOTTI, Evani Carvalho. Estratégias de } \\
\text { impessoalização no português brasileiro. In: FIORIN, José Luiz; } \\
\text { PETTER, Margarida (Eds.). África no Brasil: a formação da língua } \\
\text { portuguesa, São Paulo, Contexto:179-203, 2008. }\end{array}$ \\
\hline 2008 & OLIVEIRA, Klebson. Rotacismos e outras rotas: fenômenos com as \\
\hline
\end{tabular}




\begin{tabular}{|c|c|}
\hline & $\begin{array}{l}\text { consoantes líquidas em textos escritos por africanos e afro- } \\
\text { descendentes no Brasil do século XIX. Estudos (UFBA), v. 37/38, p. } \\
\text { 227-260, 2008. }\end{array}$ \\
\hline 2008 & $\begin{array}{l}\text { OLIVEIRA, Klebson. Ajuntamento de fontes para a história do } \\
\text { português popular brasileiro: amores, desamores e outras espécies de } \\
\text { dores. Cadernos de Estudos Lingüísticos (UNICAMP), v. } 50 \text { (2), p. } \\
\text { 217-230, 2008. }\end{array}$ \\
\hline 2008 & $\begin{array}{l}\text { OLIVEIRA, Márcia Santos Duarte. Línguas africanas - breves } \\
\text { considerações sobre seu conhecimento e pesquisa e sua relação com o } \\
\text { português do Brasil. Guavira Letras, v. 6, p. 53-66, } 2008 \text {. }\end{array}$ \\
\hline 2008 & $\begin{array}{l}\text { OLIVEIRA, Márcia Santos Duarte. Algumas considerações sobre a } \\
\text { importância da continuidade de estudos etnolinguísticos africanos para } \\
\text { o conhecimento da etnolinguística brasileira. In: SILVA, Maria do } \\
\text { Perpétuo S. Cardoso. (Org.). As interfaces dos estudos linguísticos. } \\
\text { Belém: EDUNAMA, 2008, v. 4, p. 105-110. }\end{array}$ \\
\hline 2008 & $\begin{array}{l}\text { PETTER, Margarida Maria Taddoni. Variedades lingüísticas em } \\
\text { contato: português angolano, português brasileiro, português } \\
\text { moçambicano. Tese de livre-docência. São Paulo, 2008. Concurso para } \\
\text { a livre docência - Faculdade de Filosofia, Letras e Ciências Humanas, } \\
\text { Universidade de São Paulo. }\end{array}$ \\
\hline 2008 & $\begin{array}{l}\text { PETTER, Margarida Maria Taddoni. Uma hipótese explicativa do } \\
\text { contato entre o português e as línguas africanas. Papia (Brasília), v. 1, } \\
\begin{array}{llcl}\text { p. } & 2008 . & \text { Disponível } & \text { em: } \\
\text { http://abecs.dominiotemporario.com/ojs/index.php/papia/article/viewFi } \\
\text { le/6/17-1 Acesso em: } 01 / 03 / 2013 .\end{array}\end{array}$ \\
\hline 2008 & $\begin{array}{l}\text { QUEIROZ, Sônia. Vozes da África em terras diamantinas. Minas } \\
\text { Gerais, Suplemento Literário, v. 1, p. 1-3, } 2008 .\end{array}$ \\
\hline 2008 & $\begin{array}{l}\text { RIBEIRO, Ilza; FIGUEIREDO, Maria Cristina. Orações relativas em } \\
\text { textos de africanos na Bahia oitocentista. In: MEIRA, Vivian. (Org.). } \\
\text { Português Brasileiro: estudos funcionalistas e sociolinguísticos. } \\
\text { Salvador: EDUNEB, p. 146-175, } 2008 \text {. }\end{array}$ \\
\hline 2008 & $\begin{array}{l}\text { RIBEIRO, Ilza. O sujeito nulo referencial no português popular } \\
\text { brasileiro - século XIX. In: MORAIS, Maria Aparecida Torres; }\end{array}$ \\
\hline
\end{tabular}




\begin{tabular}{|c|c|}
\hline & $\begin{array}{l}\text { ANDRADE, Maria Lucia Oliveira. (Org.). História do Português } \\
\text { Paulista: Série Estudos. Campinas: Editora da UNICAMP, 2008, v. } 2 .\end{array}$ \\
\hline 2008 & $\begin{array}{l}\text { ROCHA DA SILVA, Cláudia. Vozes do Silêncio: a linguagem } \\
\text { quilombola e o preconceito lingüístico-racial em Rio de Contas na } \\
\text { Bahia. Salvador, 2008. Dissertação (Mestrado em Educação e } \\
\text { Contemporaneidade) - Universidade do Estado da Bahia. }\end{array}$ \\
\hline 2009 & $\begin{array}{l}\text { ALKMIM, Tânia Maria; LOPEZ, Laura Álvarez. Registros da } \\
\text { escravidão: as falas de pretos-velhos e de Pai João. Stockholm Review } \\
\text { of Latin American Studies, v. 4, p. 37-48, } 2009 \text {. }\end{array}$ \\
\hline 2009 & $\begin{array}{l}\text { ALKMIM, Tânia Maria. Itinerários linguísticos de africanos e seus } \\
\text { descendentes no Brasil do século XIX. In: CARVALHO, Ana Maria } \\
\text { (Org.). Português em contato. Madri: Iberoamericana, 2009, v. 2, p. } \\
\text { 177-197. }\end{array}$ \\
\hline 2009 & $\begin{array}{l}\text { ALMEIDA, Norma Lucia Fernandes de; CARNEIRO, Zenaide } \\
\text { Oliveira Novais. Sujeito. In: LOBO, Tânia; OLIVEIRA, Klebson. } \\
\text { (Org.). África à Vista: dez estudos sobre o português escrito por } \\
\text { africanos no Brasil do século XIX. Salvador: EDUFBA, 2009, p. 70- } \\
89 .\end{array}$ \\
\hline 2009 & 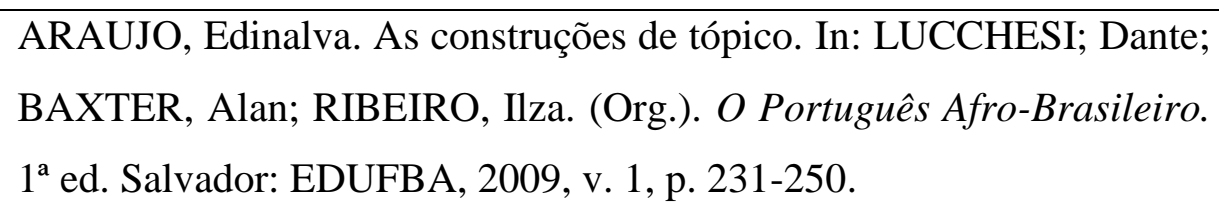 \\
\hline 2009 & $\begin{array}{l}\text { ARAUJO, Edinalva. Tópico. In: LOBO, Tânia; OLIVEIRA, Klebson } \\
\text { (Orgs). África à vista: dez estudos sobre o português escrito por } \\
\text { africanos no Brasil do século XIX. Salvador: EDUFBA, 2009, p. 50- } \\
69 .\end{array}$ \\
\hline 2009 & $\begin{array}{l}\text { ARAUJO, Silvana Silva de Farias; ARAUJO, Jean Marcel de Oliveira. } \\
\text { A formação sócio-histórica do português do Brasil: contribuições do } \\
\text { recôncavo baiano. Cadernos de Letras da UFF - Dossiê: Difusão da } \\
\text { língua portuguesa, no 39, p. 95-116, } 2009 \text {. } \\
\text { Disponível } \\
\text { http://www.cadernosdeletras.uff.br/anteriores/images/stories/edicoes/3 } \\
\text { 9/artigo5.pdf Acesso em 21/09/2013. }\end{array}$ \\
\hline 2009 & ARAÚJO, Paulo Jeferson Pilar. Aspectos semântico-cognitivos de usos \\
\hline
\end{tabular}




\begin{tabular}{|c|c|}
\hline & $\begin{array}{l}\text { espaciais das preposições "para" e "em" na fala de comunidades } \\
\text { quilombolas. São Paulo, 2009. Dissertação (Mestrado em Linguística) } \\
\text { - Faculdade de Filosofia, Letras e Ciências Humanas, Universidade de } \\
\text { São Paulo. }\end{array}$ \\
\hline 2009 & $\begin{array}{l}\text { ARAÚJO, Paulo Jeferson Pilar. Alternância no uso das preposições } \\
\text { "para" e "em" na fala de comunidades quilombolas: análise sob a } \\
\text { perspectiva da Linguística Cognitiva. Estudos Linguísticos (São } \\
\text { Paulo), v. 38, p. 335-346, } 2009 \text {. }\end{array}$ \\
\hline 2009 & $\begin{array}{l}\text { AVELAR, Juanito Ornelas; CYRINO, Sônia. Locativos em posição de } \\
\text { sujeito: línguas bantas e português brasileiro. In: TORRES MORAIS, } \\
\text { Maria Aparecida; ANDRADE, Maria Lúcia da Cunha Victório de } \\
\text { Oliveira. (Org.). História do Português Paulista. Campinas: } \\
\text { Publiel/Fapesp, 2009, v. II, p. 218-249. }\end{array}$ \\
\hline 2009 & $\begin{array}{l}\text { AVELAR, Juanito Ornelas; CYRINO, Sônia; GALVES, Charlotte. } \\
\text { Locative Inversion and Agreement Patterns: Parallelisms between } \\
\text { Brazilian Portuguese and Bantu Languages. In: PETTER, Margarida; } \\
\text { MENDES, Ronald. (Org.). Exploring the African Language } \\
\text { Connection in the Americas - Proceedings of the Special Word } \\
\text { Congress of African Linguistics (2008). São Paulo: Humanitas, 2009, } \\
\text { v. 1, p. 207-221. }\end{array}$ \\
\hline 2009 & $\begin{array}{l}\text { BARRETO, Therezinha. Articulações de orações e emprego de } \\
\text { conectores interfrásticos. In: LOBO, Tânia; OLIVEIRA, Klebson } \\
\text { (Orgs). África à vista: dez estudos sobre o português escrito por } \\
\text { africanos no Brasil do século XIX. Salvador: EDUFBA, 2009, p. 241- } \\
254 \text {. }\end{array}$ \\
\hline 2009 & 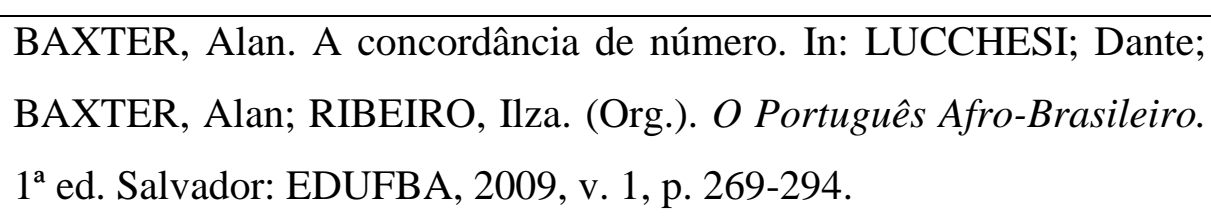 \\
\hline 2009 & 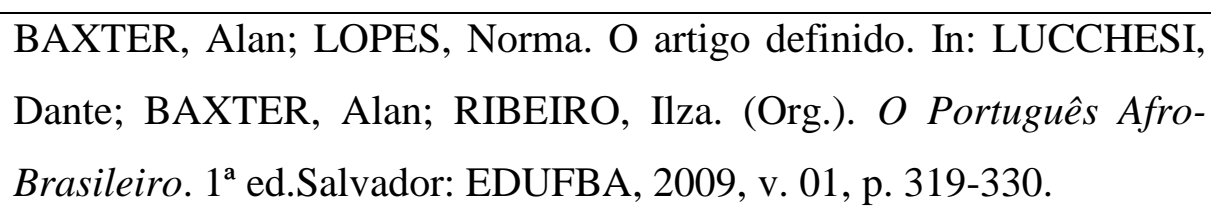 \\
\hline 2009 & BAXTER, Alan. Concordância Verbal. In: LOBO, Tânia; OLIVEIRA, \\
\hline
\end{tabular}




\begin{tabular}{|c|c|}
\hline & $\begin{array}{l}\text { Klebson (Orgs). África à vista: dez estudos sobre o português escrito } \\
\text { por africanos no Brasil do século XIX. Salvador: EDUFBA, 2009, p. } \\
\text { 317-337. }\end{array}$ \\
\hline 2009 & $\begin{array}{l}\text { BITTENCOURT, Regina Lúcia. Apagamento dos pronomes clíticos de } \\
\text { forma reflexiva. In: LOBO, Tânia; OLIVEIRA, Klebson (Orgs). África } \\
\text { à vista: dez estudos sobre o português escrito por africanos no Brasil } \\
\text { do século XIX. Salvador: EDUFBA, 2009, p. 90-137. }\end{array}$ \\
\hline 2009 & $\begin{array}{l}\text { CASTRO, Yeda Pessoa. O português do Brasil, uma intromissão nessa } \\
\text { história. In: GALVES, Charlotte, GARMES, Helder, RIBEIRO, } \\
\text { Fernando Rosa. (Org.). África-Brasil: caminhos da língua portuguesa. } \\
\text { Campinas: Editora Unicamp, } 2009 \text {, p. 175-184. }\end{array}$ \\
\hline 2009 & $\begin{array}{l}\text { CASTRO, Yeda Pessoa. Marcas lexicais africanas em contextos afro- } \\
\text { brasileiros. KILOMBO Revue Annueile Pluridisciplinaire du } \\
\text { CERAFIA, v. 05, p. 119-131, 2009. }\end{array}$ \\
\hline 2009 & $\begin{array}{l}\text { CASTRO, Yeda Pessoa. A participação de falantes africanos na } \\
\text { história do português do Brasil. In: GÄRTNER, Eberhard; } \\
\text { SCHÖNBERGER, Axel (Org.). Estudos sobre o português brasileiro. } \\
\text { Frankfurt: Valentia, 2009, v. 8, p. 85-98. }\end{array}$ \\
\hline 2009 & $\begin{array}{l}\text { CASTRO, Yeda Pessoa. A Identidade Tecida pela Palavra. Revista do } \\
\text { Instituto Geográphico e Histórico da Bahia, v. 104, p. 30-45, } 2009 .\end{array}$ \\
\hline 2009 & $\begin{array}{l}\text { CAVALCANTE, Rerisson. A negação sentencial. In: LUCCHESI, } \\
\text { Dante; BAXTER, Alan; RIBEIRO, Ilza (Org.). Português afro- } \\
\text { brasileiro. Salvador: Edufba, } 2009 \text {, p. } 251-266 .\end{array}$ \\
\hline 2009 & $\begin{array}{l}\text { CAVALCANTE, Rerisson; FIGUEIREDO, Maria Cristina Vieira } \\
\text { de. Complementos diretos e indiretos. In: LOBO, Tânia; OLIVEIRA, } \\
\text { Klebson (Orgs). África à vista: dez estudos sobre o português escrito } \\
\text { por africanos no Brasil do século XIX. Salvador: EDUFBA, 2009, p. } \\
\text { 90-137. }\end{array}$ \\
\hline 2009 & $\begin{array}{l}\text { FIGUEIREDO, Maria Cristina Vieira de; LUCCHESI, Dante. As } \\
\text { formas variáveis de realização do objeto direto anafórico nas duas } \\
\text { grandes vertentes do Português brasileiro: a rural e a urbana. Revista } \\
\text { Outros Sertões, v. 1, p. 1-341, } 2009 \text {. }\end{array}$ \\
\hline 2009 & FIGUEIREDO, Maria Cristina Vieira de. Objeto Direto Anafórico: a \\
\hline
\end{tabular}




\begin{tabular}{|c|c|}
\hline & $\begin{array}{l}\text { categoria vazia e o pronome lexical. In: LUCCHESI, Dante; BAXTER, } \\
\text { Alan; RIBEIRO, Ilza. (Org.). O Português Afro-brasileiro. Salvador: } \\
\text { Edufba, } 2009 \text {, p. } 409-427 .\end{array}$ \\
\hline 2009 & $\begin{array}{l}\text { FIGUEIREDO, Maria Cristina Vieira de; RIBEIRO, Ilza. As } \\
\text { Sentenças Relativas em Atas Escritas por Africanos no Brasil } \\
\text { Oitocentista (1832-1842). In: MEIRE, Vivian. (Org.). O Português } \\
\text { Brasileiro: Estudos Funcionalistas e Sociolinguísticos. Salvador: } \\
\text { EDUNEB, 2009. }\end{array}$ \\
\hline 2009 & $\begin{array}{l}\text { FIGUEIREDO, Maria Cristina Vieira de. O objeto nulo no português } \\
\text { rural baiano. Teoria temática e elipse de DP. Salvador, 2009. } 207 \\
\text { folhas. Tese (Doutorado em Letras e Linguística) - Instituto de Letras, } \\
\text { Universidade Federal da Bahia. }\end{array}$ \\
\hline 2009 & $\begin{array}{l}\text { GALVES, Charlotte; LOBO, Tânia. Ordem dos clíticos. In: Lobo, } \\
\text { Tânia; Oliveira, Klebson. (Org.). África à vista: dez estudos sobre o } \\
\text { português escrito por africanos no Brasil do século XIX. Salvador: } \\
\text { EDUFBA, 2009, p. 174-207. }\end{array}$ \\
\hline 2009 & $\begin{array}{l}\text { LUCCHESI, Dante. Conclusão. In: LUCCHESI; Dante; BAXTER, } \\
\text { Alan; RIBEIRO, Ilza. (Org.). O Português Afro-Brasileiro. } 1^{\mathrm{a}} \text { ed. } \\
\text { Salvador: EDUFBA, v. 1, p. 513-548, } 2009 .\end{array}$ \\
\hline 2009 & $\begin{array}{l}\text { LUCCHESI, Dante. História do Contato entre Línguas no Brasil. In: } \\
\text { LUCCHESI; Dante; BAXTER, Alan; RIBEIRO, Ilza. (Org.). O } \\
\text { Português Afro-Brasileiro. } 1^{\text {a }} \text { ed. Salvador: EDUFBA, v. 1, p. 41-73, } \\
2009 .\end{array}$ \\
\hline 2009 & $\begin{array}{l}\text { LUCCHESI, Dante; BAXTER, Alan; SILVA, Jorge Augusto Alves da; } \\
\text { Figueiredo, Maria Cristina Vieira de. O Português Afro-Brasileiro: as } \\
\text { comunidades analisadas. In: LUCCHESI; Dante; BAXTER, Alan; } \\
\text { RIBEIRO, Ilza. (Org.). O Português Afro-Brasileiro. } 1^{\text {a }} \text { ed. Salvador: } \\
\text { EDUFBA, } 2009 \text {, v. 1, p. } 75-100 \text {. }\end{array}$ \\
\hline 2009 & $\begin{array}{l}\text { LUCCHESI, Dante; BAXTER, Alan. A Transmissão Linguística } \\
\text { Irregular. In: LUCCHESI; Dante; BAXTER, Alan; RIBEIRO, Ilza. } \\
\text { (Org.). O Português Afro-Brasileiro. } 1^{\mathrm{a}} \text { ed. Salvador: EDUFBA, v. 1, } \\
\text { p. 101-124, } 2009\end{array}$ \\
\hline 2009 & LUCCHESI, Dante; RIBEIRO, Ilza. Teorias da estrutura e da mudança \\
\hline
\end{tabular}




\begin{tabular}{|c|c|}
\hline & $\begin{array}{l}\text { linguísticas e contato entre línguas. In: LUCCHESI; Dante; BAXTER, } \\
\text { Alan; RIBEIRO, Ilza. (Org.). O Português Afro-Brasileiro. } 1^{\mathrm{a}} \text { ed. } \\
\text { Salvador: EDUFBA, v. 1, p. 125-153, } 2009\end{array}$ \\
\hline 2009 & 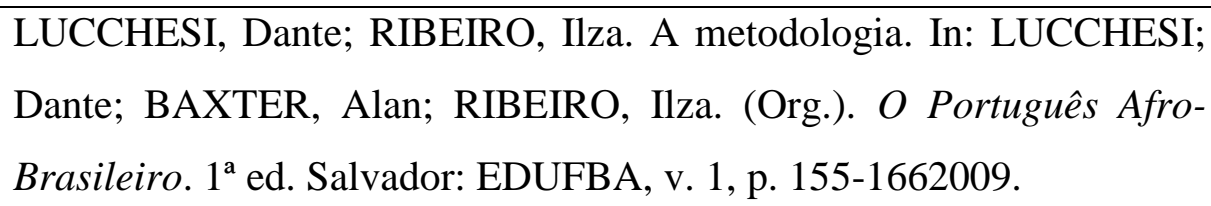 \\
\hline 2009 & $\begin{array}{l}\text { LUCCHESI, Dante. A realização do sujeito pronominal. In: } \\
\text { LUCCHESI; Dante; BAXTER, Alan; RIBEIRO, Ilza. (Org.). O } \\
\text { Português Afro-Brasileiro. } 1^{\mathrm{a}} \text { ed. Salvador: EDUFBA, v. 1, p. 167- } \\
184,2009\end{array}$ \\
\hline 2009 & $\begin{array}{l}\text { LUCCHESI, Dante; MELLO, Camila Ferreira de. A alternância dativa } \\
\text { no português afro-brasileiro: um processo de reestruturação original da } \\
\text { gramática. Papia, Brasília, v. } 19 \text {, p. } 153-184,2009 \text {. }\end{array}$ \\
\hline 2009 & $\begin{array}{l}\text { LUCCHESI, Dante. A concordância de gênero. In: LUCCHESI; } \\
\text { Dante; BAXTER, Alan; RIBEIRO, Ilza. (Org.). O Português Afro- } \\
\text { Brasileiro. } 1^{\text {a }} \text { ed. Salvador: EDUFBA, v. 1, p. 295-318. } 2009 .\end{array}$ \\
\hline 2009 & $\begin{array}{l}\text { LUCCHESI, Dante; BAXTER, Alan; SILVA, Jorge Augusto Alves da } \\
\text { Silva. A concordância verbal. In: LUCCHESI; Dante; BAXTER, Alan; } \\
\text { RIBEIRO, Ilza. (Org.). O Português Afro-Brasileiro. } 1^{\text {a }} \text { ed. Salvador: } \\
\text { EDUFBA, v. 1, p. 331-371, } 2009 \text {. }\end{array}$ \\
\hline 2009 & $\begin{array}{l}\text { LUCCHESI, Dante. A concordância em estruturas passivas e de } \\
\text { predicativo do sujeito. In: LUCCHESI; Dante; BAXTER, Alan; } \\
\text { RIBEIRO, Ilza. (Org.). O Português Afro-Brasileiro. } 1^{\text {a }} \text { ed. Salvador: } \\
\text { EDUFBA, v. 1, p. 373-387, } 2009 \text {. }\end{array}$ \\
\hline 2009 & $\begin{array}{l}\text { LUCCHESI, Dante; MELLO, Camila Ferreira de. Alternância dativa. } \\
\text { In: LUCCHESI; Dante; BAXTER, Alan; RIBEIRO, Ilza. (Org.). } O \\
\text { Português Afro-Brasileiro. } 1^{\mathrm{a}} \text { ed. Salvador: EDUFBA, v. 1, p. } 427- \\
\text { 456, } 2009 \text {. }\end{array}$ \\
\hline 2009 & $\begin{array}{l}\text { LUCCHESI, Dante; MENDES, Elisângela dos Passos. A flexão de } \\
\text { caso dos pronomes pessoais. In: LUCCHESI; Dante; BAXTER, Alan; } \\
\text { RIBEIRO, Ilza. (Org.). O Português Afro-Brasileiro. } 1^{\text {a }} \text { ed. Salvador: } \\
\text { EDUFBA, v. 1, p. 471-488, } 2009 \text {. }\end{array}$ \\
\hline 2009 & LUCCHESI, Dante; ARAÚJO, Silvana Silva de Farias. O sistema de \\
\hline
\end{tabular}




\begin{tabular}{|c|c|}
\hline & $\begin{array}{l}\text { expressão de posse. In: LUCCHESI; Dante; BAXTER, Alan; } \\
\text { RIBEIRO, Ilza. (Org.). O Português Afro-Brasileiro. } 1^{\mathrm{a}} \text { ed. Salvador: } \\
\text { EDUFBA, v. 1, p. 489-511, } 2009 .\end{array}$ \\
\hline 2009 & 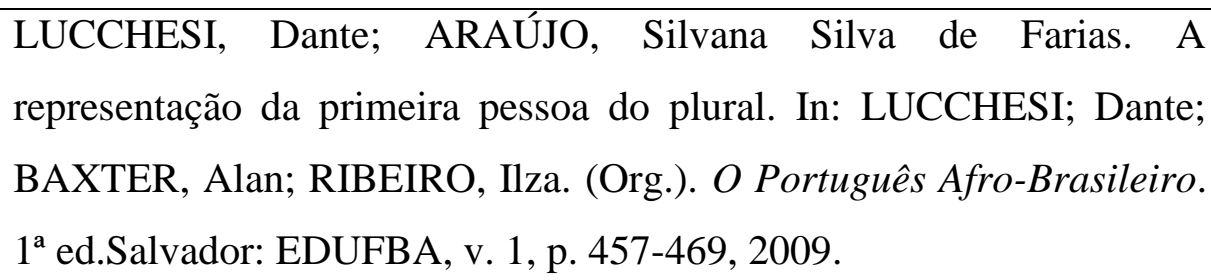 \\
\hline 2009 & $\begin{array}{l}\text { LUCCHESI, Dante. Aspectos da gramática do português brasileiro } \\
\text { afetados pelo contato entre línguas: a flexão de caso dos pronomes } \\
\text { pessoais. In: MEIRA, Vivian. (Org.). Português Brasileiro: estudos } \\
\text { funcionalistas e sociolinguísticos. } 1^{\text {a }} \text { ed. Salvador: EDUNEB, v. 1, p. } \\
\text { 41-79, 2009. }\end{array}$ \\
\hline 2009 & $\begin{array}{l}\text { MATTOS e SILVA, Rosa Virgínia; MACHADO FILHO, Américo } \\
\text { Venâncio Lopes. Variação TER/HAVER. In: LOBO, Tânia; } \\
\text { OLIVEIRA, Klebson. (Org.). África à vista: dez estudos sobre o } \\
\text { português escrito por africanos no Brasil do século XIX. Salvador: } \\
\text { EDUFBA, p. 338-351, 2009. }\end{array}$ \\
\hline 2009 & $\begin{array}{l}\text { MATTOS e SILVA, Rosa Virgínia; MACHADO FILHO, Américo } \\
\text { Venâncio Lopes. Entre duas diásporas: o português e as línguas } \\
\text { africanas no Brasil. In: OLIVEIRA, Klebson; CUNHA E SOUZA, } \\
\text { Hirão; SOLEDADE, Juliana. (Org.). Do português arcaico ao } \\
\text { português brasileiro: outras histórias. Salvador: EDUFBA, 2009, p. } \\
\text { 297-304. }\end{array}$ \\
\hline 2009 & $\begin{array}{l}\text { MEIRA, Vívian. O emprego do modo subjuntivo. In: LUCCHESI; } \\
\text { Dante; BAXTER, Alan; RIBEIRO, Ilza. (Org.). O Português Afro- } \\
\text { Brasileiro. } 1^{\mathrm{a}} \text { ed. Salvador: EDUFBA, 2009, v. 1, p. 389-407. }\end{array}$ \\
\hline 2009 & $\begin{array}{l}\text { MEIRA, Vívian. O português falado no Brasil: evidências sócio- } \\
\text { históricas. In: MEIRA, Vivian. (Org.). Português Brasileiro: Estudos } \\
\text { Funcionalistas e Sociolinguísticos. Salvador: EDUNEB, } 2009 .\end{array}$ \\
\hline 2009 & $\begin{array}{l}\text { OLIVEIRA, Klebson. Textos de escravos no Brasil oitocentista: os } \\
\text { tempos de uma edição filológica e de uma antologia comentada de } \\
\text { alguns fatos lingüísticos. Filologia e Lingüística Portuguesa, v. 10/11, } \\
\text { p. 189-220, } 2009 \text {. }\end{array}$ \\
\hline
\end{tabular}




\begin{tabular}{|c|c|}
\hline 2009 & $\begin{array}{l}\text { OLIVEIRA, Klebson; LOBO, Tânia. Introdução ou sobre como a } \\
\text { África, no Brasil, à vista a escrita. In: LOBO, Tânia; OLIVEIRA, } \\
\text { Klebson (Orgs). África à vista: dez estudos sobre o português escrito } \\
\text { por africanos no Brasil do século XIX. Salvador: EDUFBA, p. 6-49, } \\
2009 \text {. }\end{array}$ \\
\hline 2009 & $\begin{array}{l}\text { OLIVEIRA, Klebson; SOLEDADE, Juliana; SANTOS, Verônica de } \\
\text { Souza. Concordância Nominal (cenas da variação em palcos do século } \\
\text { XIX). In: LOBO, Tânia; OLIVEIRA, Klebson (Orgs). África à vista: } \\
\text { dez estudos sobre o português escrito por africanos no Brasil do } \\
\text { século XIX. Salvador: EDUFBA, p. 255-316. } 2009 \text {. }\end{array}$ \\
\hline 2009 & $\begin{array}{l}\text { OLIVEIRA, Márcia Santos Duarte; JORGE, Lurdes. A categoria } \\
\text { tempo e a interface discurso/gramática - foco em português: } \\
\text { investigações preliminares à luz de um fenômeno areal africano. In: } \\
\text { CORTINA, Arnaldo; NASSER, Sônia Maria G. da C. (Org.). Sujeito e } \\
\text { Linguagem. São Paulo: Cultura Acadêmica, v. 17, p. } 75-96,2009 \text {. }\end{array}$ \\
\hline 2009 & $\begin{array}{l}\text { OLIVEIRA, Márcia Santos Duarte. O impacto da cultura negra na } \\
\text { constituição do novo mundo: a contribuição dos 'povos/línguas do } \\
\text { Grupo Ibom' (povos de Calabar). In: MORAES, Maria Aparecida } \\
\text { Torres; ANDRADE, Maria Lucia Oliveira. (Org.). História do } \\
\text { Português Paulista. São Paulo: FAPESP, v. 2, p. 262-272, } 2009 .\end{array}$ \\
\hline 2009 & 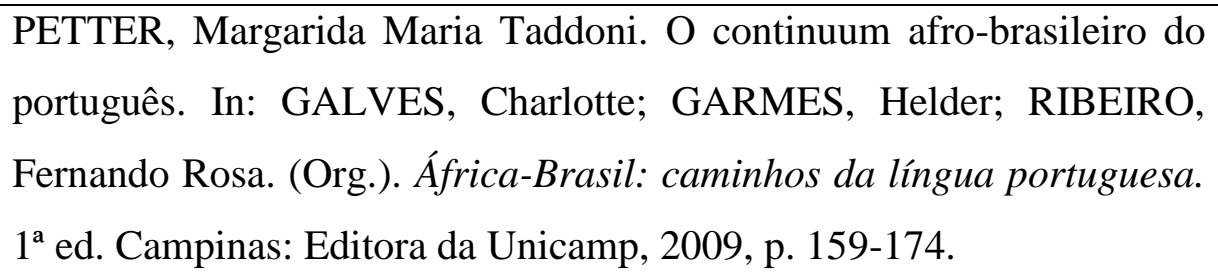 \\
\hline 2009 & $\begin{array}{l}\text { RIBEIRO, Ilza. As sentenças relativas. In: LUCCHESI, Dante; } \\
\text { BAXTER, Alan; RIBEIRO, Ilza. (Org.). O português afro-brasileiro. } \\
\text { Salvador: EDUFBA, p. 185-208, } 2009 .\end{array}$ \\
\hline 2009 & $\begin{array}{l}\text { RIBEIRO, Ilza; CÔRTES JUNIOR, Moacir. As construções pseudo- } \\
\text { clivadas e clivadas. In: LUCCHESI, Dante; BAXTER, Alan; } \\
\text { RIBEIRO, Ilza. (Org.). O português afro-brasileiro. Salvador: } \\
\text { EDUFBA, p. 209-230, 2009. }\end{array}$ \\
\hline 2009 & $\begin{array}{l}\text { RIBEIRO, Ilza; FIGUEIREDO, Maria Cristina. Relativas. In: LOBO, } \\
\text { Tânia; OLIVEIRA, Klebson. (Orgs.). África à vista. Dez estudos sobre }\end{array}$ \\
\hline
\end{tabular}




\begin{tabular}{|c|c|}
\hline & $\begin{array}{l}\text { o português escrito por africanos no Brasil do século XIX. Salvador: } \\
\text { EDUFBA, } 2009 \text {, p. } 208-240 .\end{array}$ \\
\hline 2009 & $\begin{array}{l}\text { SCHERRE, Maria Marta Pereira; NARO, Anthony Julius. Sobre as } \\
\text { origens do Português Brasileiro: garimpo fonológico. Origens do } \\
\text { Português Brasileiro. São Paulo: Parábola Editorial, p. 117-113, } 2007 . \\
\text { Publicado também em: SCHERRE, Maria Marta Pereira; NARO, } \\
\text { Anthony Julius. Sobre as origens estruturais do português brasileiro - o } \\
\text { garimpo continua. In: CARVALHO, Ana Maria. (Org.). Português em } \\
\text { Contato Lingüística luso-brasileira, 2. Madrid/Frankfurt am Main: } \\
\text { IBEROAMERICANA/EDITORIAL VERVUERT, 2009, v. 1, p. 131- } \\
\text { 151. }\end{array}$ \\
\hline 2009 & $\begin{array}{l}\text { SOUZA, Antonio Carlos Santana de. A influência das variáveis sociais } \\
\text { numa pesquisa sociolingüística em comunidades negras rurais. } \\
\text { Interletras, Dourados, v. 2, p. 1-13, } 2009 \text {. }\end{array}$ \\
\hline 2009 & $\begin{array}{l}\text { SOUZA, Antonio Carlos Santana de. Tradições discursivas e o estudo } \\
\text { dos corpora de língua falada nas comunidades quilombolas de Mato } \\
\text { Grosso do Sul. Web revista: questões de lingüística e de linguagem, v. } \\
\text { 1, p. } 300-312,2009 \text {. }\end{array}$ \\
\hline 2009 & $\begin{array}{l}\text { SOUZA, Antonio Carlos Santana de; SCHLIECK, Cleonice. } \\
\text { Comunidades afro-brasileiras isoladas em Mato Grosso do Sul: um } \\
\text { estudo sociolinguístico dos quilombos de Tia Eva e Furnas dos } \\
\text { Dionísios. Web-revista: questões de lingüística e de linguagem, v. 1, p. } \\
\text { 1-13, 2009. }\end{array}$ \\
\hline 2010 & $\begin{array}{l}\text { ANDRADE, Karylleila dos Santos; ESTEVES, Francisco Patrício; } \\
\text { LIMA, Sibéria Salles Queiroz de. Perfil sociolinguístico e } \\
\text { socioeconômico das comunidades remanescentes de quilombolas do } \\
\text { estado do Tocantins: considerações iniciais. Revista Entre Letras: } \\
\text { Revista do Curso de Mestrado em Ensino de Língua e Literatura da } \\
\text { Universidade Federal do Tocantins (UFT), Araguaína, v. 1, no 1, p. 91- } \\
\text { 117, II semestre, } 2010 \text {. }\end{array}$ \\
\hline 2010 & $\begin{array}{l}\text { CASTRO, Yeda Pessoa. A participação de falantes africanos no } \\
\text { português brasileiro: aspectos sócio-históricos e linguísticos. In: } \\
\text { Instituto Internacional da Língua Portuguesa; Associação das }\end{array}$ \\
\hline
\end{tabular}




\begin{tabular}{|c|c|}
\hline & $\begin{array}{l}\text { Universidades de Língua Portuguesa. (Org.). Interprenetração da } \\
\text { língua e culturas delem língua portuguesa na CPLP. } 1^{\mathrm{a}} \text { ed. Praia - } \\
\text { Cabo Verde: Instituto IILP e AULP, 2010, p. 106-115. }\end{array}$ \\
\hline 2010 & $\begin{array}{l}\text { FONSECA, Hely Dutra Cabral da. Marcas do passado no Português do } \\
\text { Brasil e D'Angola. Revista Humanas, UFES, v. 2, p. 1-12, } 2010 .\end{array}$ \\
\hline 2010 & $\begin{array}{l}\text { NARO, Anthony Julius; SCHERRE, Maria Marta Pereira. Fluxos e } \\
\text { contrafluxos - movimentos sociolinguísticos da comunidade de fala } \\
\text { brasileira. In: MOLLICA, Maria Cecília de Magalhães. (Org.). Usos da } \\
\text { linguagem e sua relação com a mente humana. Rio de Janeiro: Tempo } \\
\text { Brasileiro, 2010, p. 79-91. }\end{array}$ \\
\hline 2010 & $\begin{array}{l}\text { NEGRÃO, Esmeralda Vailati; VIOTTI, Evani Carvalho. A estrutura } \\
\text { sintática das sentenças absolutas no português brasileiro. Lingüistica } \\
\text { (Madrid), v. } 23 \text {, p. } 37-58,2010 \text {. }\end{array}$ \\
\hline 2010 & $\begin{array}{l}\text { OLIVEIRA, Klebson. Fontes para a história do português popular } \\
\text { brasileiro: partidas e contrapartidas. Revista Internacional de } \\
\text { Lingüística Iberoamericana, v. 16, p. 9-28, } 2010 \text {. }\end{array}$ \\
\hline 2010 & $\begin{array}{l}\text { OLIVEIRA, Márcia Santos Duarte; FERNANDES, Jonas Tadeu } \\
\text { Viccari. Aspectos Etnolinguísticos da Fala de uma Comunidade } \\
\text { Quilombola do Pará: Jurussaca. Cadernos Ceru (USP), v. 21, p. 13-32, } \\
2010 .\end{array}$ \\
\hline 2010 & $\begin{array}{l}\text { RASO, Tomasso; MELLO, Heliana. As especificidades da unidade de } \\
\text { tópico em PB e possíveis efeitos do contato linguístico. In: SARAIVA, } \\
\text { Maria Elizabeth Fonseca; MARINHO, Janice Helena Chaves (Org.). } \\
\text { Estudos da língua em uso. Belo Horizonte: Editora UFMG, } 2010 .\end{array}$ \\
\hline 2010 & $\begin{array}{l}\text { PETTER, Margarida Maria Taddoni. Línguas africanas no Brasil. } \\
\text { África (USP), v. } 27 / 28, \text { p. } 63-89,2010 \text {. }\end{array}$ \\
\hline
\end{tabular}

\subsection{Observações gerais sobre a bibliografia}

Iniciamos a observação pelo apontamento de alguns dados quantitativos. No quadro-resumo a seguir, apontamos a quantidade de textos selecionados a cada período. 


\begin{tabular}{|c|c|}
\hline Período & Quantidade de textos \\
\hline $1870-1879$ & $1^{1}$ \\
\hline $1880-1889$ & 0 \\
\hline $1890-1899$ & 0 \\
\hline 1900-1909 & 0 \\
\hline $1910-1919$ & 0 \\
\hline 1920-1929 & 6 \\
\hline $1930-1939$ & 11 \\
\hline 1940-1949 & 9 \\
\hline $1950-1959$ & 6 \\
\hline 1960-1969 & 10 \\
\hline 1970-1979 & 13 \\
\hline 1980-1989 & 18 \\
\hline 1990-1999 & 48 \\
\hline $2000-2010$ & 200 \\
\hline Total & 322 \\
\hline
\end{tabular}

Algumas ressalvas se fazem necessárias:

1) embora se trate de uma seleção, e não de um registro exaustivo de referências, nossa bibliografia constituiu-se a partir dos critérios que mencionamos no início deste capítulo, refletindo, nessa medida, os movimentos gerais da produção que particularmente nos interessou acompanhar.

2) ainda que resguardados os critérios de seleção, é possível que os números não estejam absolutamente corretos, dada a dificuldade de obter referências, identificar e localizar os textos mais antigos, principalmente os da virada do século XIX para o XX. Quanto aos mais atuais, essa dificuldade revelou-se muito menor (no caso dos muito recentes, da virada do século XX para o XXI,

\footnotetext{
${ }^{1}$ Levamos em conta aqui Os Estudos Lexicográficos de Macedo Soares que reúnem artigos publicados no período de 1974 a 1890, já que a obra de Nina Rodrigues parece ter surgido apenas na década de $1930 \mathrm{em}$ publicação.
} 
há inclusive um porcentual razoável de arquivos digitais disponibilizados na internet). ${ }^{2}$

Dito isso, a análise desses dados quantitativos aponta que, após os textos mais propriamente linguísticos de Macedo Soares, publicados ao longo de quase duas décadas, e o trabalho mais generalista de Nina Rodrigues, também elaborado na virada do século XIX para o XX, mas publicado em 1932, parece ter havido um intervalo de menor visibilidade do tema entre 1900 e 1920 (não localizamos nenhuma produção); na década de 20, ele ressurge, colateralmente, em trabalhos preocupados com dialetos específicos ou com a "língua nacional" e também figura, em outros textos, como o centro da discussão (v. Pontes, Senna) ${ }^{3}$.

Nos anos 1930, mais povoado do ponto de vista quantitativo, as duas tendências 'análise colateral' (relacionada ao estudo da história da língua, dos dialetos ou de outros domínios culturais) e 'análise central' (que toma o problema como foco, centro de interesse) permanecem e, no segundo filão, dão ensejo a textos que se tornariam "clássicos" na área: os de Raymundo e Mendonça. Essa década também presencia a edição de obras póstumas, como a de Nina Rodrigues, o que talvez possa ter relação com alguma espécie de aquecimento de discussões relativas à 'raça' e 'etnia' nos círculos intelectuais locais.

Entre os anos 1940 e 1960, parece que a tendência de tratamento mais 'colateral' do tema, verificada na década de 1920, se fortalece novamente, ainda que haja textos que o tomem de modo mais 'central' aparecendo esporadicamente. As preocupações parecem mais voltadas para o estudo da história da língua portuguesa, e a relação PB e línguas africanas aparece como um dos múltiplos aspectos chamados para a explicação daquela questão mais ampla.

Entre o final dos anos 1960 e a década de 1980, surgem títulos que remetem ao contexto africano, aos quilombos, aos registros especiais, assinalando, aparentemente, um primeiro movimento no sentido de dividir o foco, até ali concentrado 'no português

\footnotetext{
2 A produção de um corpus digitalizado dos trabalhos 'antigos' parece, pois, ter interesse epihistoriográfico.

${ }^{3}$ É possível que nesse período estivessem sendo gestados os estudos que se publicam a partir de 1920. O mais comum, até, pelo menos os anos 1950, era a elaboração de estudos mais amplos, no formato de livros, que provavelmente requeriam mais tempo para serem concluídos. Também é possível que algo do contexto dos estudos da língua (como uma maior preocupação com o estabelecimento de normas de uso) tenha contribuído para isso. Finalmente, é possível ainda que o levantamento, apesar de todos os esforços e cuidados de busca e de checagem de informações, tenha simplesmente falhado nesse ponto. Em vista dessa concorrência entre hipóteses, não arriscaremos comentário específico sobre essa ausência.
} 
e no contexto brasileiro', com as especificidades das 'línguas africanas e do contexto do africano' (na África ou no Brasil). Fragmentando um pouco este grande bloco temporal, podemos observar que: a) na década de 60, há uma pesquisa mais diversificada que aquelas realizadas até os anos 1950, já que, aos ainda preponderantes estudos históricos da língua portuguesa, juntam-se trabalhos que lançam o olhar para os africanos e suas línguas, como os de Castro, e também interessados em crioulística, como o de Carlota Ferreira; b) na década de 70 , tem-se mais notícias de pesquisas realizadas junto a comunidades negras e quilombolas. Continuam as abordagens da influência e da crioulização. O termo 'contato' aparece aqui pela primeira vez em nosso mapeamento, no trabalho de Rosa Virgínia Mattos e Silva denominado "Aspectos do contato linguístico no Brasil”. Universitas, Salvador, n.24, p. 83-95, 1979; c) na década de 1980, parece se consolidar, como mais definitiva, a 'descoberta' da África no Brasil. Insinuada a partir do final dos anos 1960, em trabalhos como os de Castro e Ferreira, África torna-se termo mais frequente nos títulos e exploram-se mais as 'línguas africanas secretas' (ou 'línguas dos negros') das comunidades de afrodescendentes. Discute-se a existência de pidgins e crioulos no Brasil, inclusive a partir da retomada de textos sobre sua história e formação, publicados até os anos 1950 (como os da geração de filólogos dos anos 1940 e 1950). Aspectos como identidade e política, mote para trabalhos como os de Macedo Soares, no século XIX e alguns dos trabalhos do começo do século XX, são reintroduzidos em lugar de destaque em algumas das propostas.

A partir da década de 1990, a produção sobre a relação do PB com as línguas africanas cresce significativamente e experimenta intenso aumento entre 2000 e 2010 (com 200 títulos concentrados apenas nessa década). Esse aumento acompanha o aumento da produção científica em geral e linguística, em particular, no mesmo período. Como observamos em outro ponto, houve uma mudança importante na forma de se conceber e de se realizar o trabalho acadêmico nas últimas décadas, que favoreceu a multiplicação, mas uma multiplicação acompanhada de forte fragmentação - seja quando se consideram domínios cada vez mais especializados, seja quando se considera o lugar atualmente ocupado por formatos textuais mais ligeiros que o livro, como artigos, capítulos de livros organizados com múltiplos colaboradores, etc.

Até onde os títulos e o exame superficial de alguns dos textos permitem observar, há indícios de que, seguindo a tendência verificada em todo o período aqui considerado, os textos desse último intervalo (1990-2010) são diversificados, quanto às abordagens, ao aporte teórico e à maior ou menor centralidade (ou colateralidade) 
conferida ao tema PB-línguas africanas. Parece haver, no entanto, a emergência de abordagens mais especializadas e mais pontuais, voltadas para temas de interesse da Linguística geral, seja nos domínios de descrição gramatical, lexical, textual e discursiva. Também ganham força nesta etapa novos vieses diacrônicos e o viés sociolinguístico. Em análise mais pormenorizada, se na década de 1990 ganham destaque os trabalhos ancorados na Sociolinguística e na Teoria Gerativa da Gramática (que convivem com estudos dos 'falares' de comunidades afro-brasileiras e de dialetos rurais e também com descrições mais estruturais e culturalistas), nos anos 2000, a novidade é menos teórica do que material: é a comparação do PB com outras variedades do Português, que não apenas a lusitana. A discussão em termos de 'influência' e 'crioulização' persiste. O termo ‘contato' parece estar disseminado por essa produção. Esse período, ao dar forte visibilidade ao domínio sintático, introduz uma ruptura importante, já que boa parte da produção anterior, desde o século XIX, se dedicou ao exame do léxico. O tratamento preferencial do léxico é, aliás, um dos traços persistentes dessa tradição. A lacuna em relação a um domínio morfossintático parece estar sendo preenchida aos poucos, nos últimos anos.

Ainda com remissão aos títulos e ao contato que tivemos com algumas das obras, acrescentamos às observações anteriores, estas outras:

- análise do léxico português de origem, bem como o uso do termo 'influência' são persistentes ao longo de todo o período, sendo preponderante entre 1800 a 1950);

- ao lado dos textos produzidos por estudiosos da linguagem, são relevantes para a constituição dessa tradição linguística, também de forma descontínua, mas ao longo de todo o período considerado, os ensaios sobre etnia, história, cultura, costumes; ao lado desses aspectos, a língua é também tomada, em tais trabalhos, como um domínio em que o 'elemento-negro' 'influenciou' a formação do Brasil;

- outra persistência é a vinculação do tema aos primeiros momentos de formação histórica da língua portuguesa, em geral, ou do PB, com a África e suas línguas consideradas em perspectiva colateral. Essa tendência sofre algum abalo a partir do final da década de 1960 e também na produção mais contemporânea, na qual, além de se reconhecer a relevância de se estudar mais outras variedades, se começa a fazê-lo, de modo incipiente.

- é também bastante forte a localização de herança africana em estratos específicos da língua (rurais, remanescentes africanos, popular, familiar, secreto) 
-rupturas importantes parecem se colocar nos anos 1930, com uma espécie de legitimação do tema; no final dos anos 1960, com o início das tentativas de se conferir um papel mais destacado à África, na contemporaneidade, com a atenção à gramática e inserção da relação num contexto pluricontinental.

Nossas observações são panorâmicas em vista da impossibilidade de realizar exame mais acurado dessa ampla produção.

No próximo capítulo, com o objetivo de viabilizar uma análise um pouco mais aprofundada acerca da natureza dessa produção - apenas esboçada aqui a partir da quantificação, do exame dos títulos, e do contato direto com uma parte dos trabalhos -, examinaremos mais minuciosamente alguns 'exemplares' (cf. Kuhn 1962). Esse exame permitiu observações um pouco mais verticalizadas sobre as formas de tratamento do tema ao longo do tempo no Brasil. 


\section{Capítulo 4}

\section{ObRAS INAUGURAIS DOS ESTUdOS DO CONTATO DO PB COM AS LÍNGUAS AFRICANAS: MACEDO SOARES (1942[1874-1890]), MENDONÇA (1935[1933]), RAIMUNDO (1933) E SilVA NeTO (1950)}

Neste capítulo, apresentamos as análises dos quatro primeiros textos selecionados, a saber: Estudos lexicográficos do dialeto brasileiro (1942 [1874-1890]) de Antônio Joaquim de Macedo Soares [1838 - 1905], A influência africana no Português do Brasil de Renato Firmino Maia de Mendonça [1912 - 1990], O elemento afro-negro na Língua Portuguesa (1933) de Jacques Raimundo Ferreira da Silva [?1960? $]^{1}$ e Introdução ao estudo da língua portuguesa no Brasil (1950) de Serafim da Silva Neto (1917-1960) realizada de acordo com a metodologia apresentada no capítulo 2.

\subsection{Estudos lexicográficos do dialeto brasileiro (1942[1874-1890]) de Antônio Joaquim de Macedo Soares [1838 - 1905]}

\subsubsection{Breve perfil biográfico do autor e visão geral da obra}

Antônio Joaquim de Macedo Soares nasceu em 1838 no Rio de Janeiro e morreu na mesma cidade em 1905. Estudou no Seminário Episcopal do Rio de Janeiro, no qual concluiu o curso de Teologia (1855). Formou-se na Faculdade de Direito em São Paulo, em que recebeu o título de Bacharel em Ciências Jurídicas e Sociais (1861). Atuou como juiz nos estados do Rio de Janeiro (1862, 1882 e $1886^{2}$ ), Paraná (1874) e Minas Gerais (1876) e, posteriormente, foi ministro do Supremo Tribunal Federal (1892).

\footnotetext{
${ }^{1}$ Essas obras de Mendonça e Raimundo são consideradas (cf. Bonvini 2009, Petter 1998, entre outros) como prototípicas dos estudos sobre a relação entre o PB e as línguas africanas vista da perspectiva da 'influência'. Ambos são, também, frequentemente citados em textos da tradição brasileira de estudos sobre esse contato como seus fundadores - para muitos, teriam sido os primeiros a realizar pesquisas aprofundadas sobre o tema. Nesse sentido, analisamos essas obras e, em certa medida, realizamos uma comparação; pois muitas vezes elas são tomadas como um conjunto uniforme.

${ }^{2}$ Datas em que Macedo Soares foi nomeado.
} 
Foi membro do Instituto Histórico e Geográfico Brasileiro (IHGB), da Sociedade Brasileira de Geografia e da Sociedade de Geografia de Lisboa. Recebeu de D. Pedro II o grau de Cavaleiro da Ordem da Rosa e de Conselheiro do Império pela Princesa Isabel. Foi também Grão Mestre da Ordem Maçônica do Brasil de 1891 a $1900^{3}$.

Segundo João Ribeiro, também filólogo, Macedo Soares era "o filólogo americanista de maior valor que possuímos”. Já Sílvio Romero [1851-1914], folclorista, historiador e crítico literário, reconhecia-o como um dos "cultores sistemáticos e teimosos do indianismo".

Com ampla atividade intelectual concentrada em trabalhos sobre Direito, destacamos aqui duas obras relativas ao estudo das Letras: Diccionario brazileiro da lingua portugueza. Elucidario etymologico-crítico das palavras e phrases que, originarias do Brazil, ou aqui populares, se não encontrão nos diccionarios da lingua portugueza, ou nelles vêm com forma ou significação differente (1889 [1875-1888]) e Estudos lexicográficos do dialeto brasileiro (1942[1874-1891]), este último, um conjunto de artigos e notas reunidos por seu filho, Julião Rangel de Macedo Soares ${ }^{4}$ [1879 - 1961], em Obras Completas, publicação da Revista do IHBG (Instituto Histórico e Geográfico Brasileiro) em 1942. Na maioria dos artigos dos Estudos, Macedo Soares centra-se na análise de termos indígenas relativos à toponímia nacional. Nessa análise, nos restringimos aos textos e notas relativos ao contato do PB com as línguas africanas, especialmente ao capítulo denominado "Sobre algumas palavras africanas introduzidas no português que se fala no Brasil" (p. 44 - 74), no qual pudemos encontrar uma maior quantidade de dados relativos ao tema por nós investigado para apreciação.

A coletânea dedicada ao estudo do 'dialeto brasileiro', com 269 páginas, dividese em um obituário, "Batista Caetano, homenagem do discípulo", "Estudos lexicográficos do dialeto brasileiro", "Filologia" e "Notas lexicográficas acêrca de...". Ao final da obra, há também os seguintes artigos e estudos avulsos: "Notas do folclore brasileiro do Sr. Valle Cabral", "Estadoal, Estadual, Estatual?", "Declaracion de La doctrina Cristiana, manuscrito guarani" e "Um manuscrito guarani”, tal como detalhado no quadro abaixo (destaques nossos):

\footnotetext{
${ }^{3}$ Informações retiradas da página do Supremo Tribunal Federal (http://www.stf.jus.br/portal/ministro/verMinistro.asp?periodo=stf\&id=154), consultada em 17.06.2014.

${ }^{4}$ Julião Rangel de Macedo Soares foi desembargador e presidente do Tribunal de Apelação do Estado do Rio de Janeiro [1936-1937], além de membro da Academia Fluminense de Letras.
} 


\begin{tabular}{|c|}
\hline Índice da obra \\
\hline Macedo Soares (A. J.) (p. 11) \\
\hline Batista Caetano, homenagem do discípulo (p. 13 - 19) \\
\hline Estudos lexicográficos do dialeto brasileiro (p. 21-122) \\
\hline I - Sobre a etimologia da palavra boava ou emboava (p. $21-29)$ \\
\hline II - Sobre a etimologia da palavra peão ou pião (p.30 - 35) \\
\hline III - Capão, capoeira, restinga (p. $35-43$ ) \\
\hline $\begin{array}{l}\text { IV - Sobre algumas palavras africanas introduzidas no português que se fala do Brasil } \\
\text { (p. } 44-74 \text { ) }\end{array}$ \\
\hline V - Chapada, chapadão, chato, lomba, planiço, varge (p. 74 - 92) \\
\hline $\begin{array}{l}\text { VI - Ahyva, jaguar, jaguary, jaguaryahyva, jaguarycatú, jaguaritica, jaguané (p. } 93 \text { - } \\
\text { 104) }\end{array}$ \\
\hline $\begin{array}{l}\text { VII - Anhanguera, batuera, canguelo, capueira, carueira, catanguera, manipueira, } \\
\text { pacueira, pirangueiro, quirera, tapera, tigüera - Exemplos do pretérito geral, da língua } \\
\text { geral, transmitidos ao dialeto brasileiro (p. } 105-112)\end{array}$ \\
\hline VIII - Barra, barro e suas formações (p. 112 - 117) \\
\hline IX - Capoeira e seus derivados (p. $117-118)$ \\
\hline $\mathrm{X}$ - Bacuara e babacuara (p. $119-120)$ \\
\hline XI - Cabra, fulla, fulo (p. 120 - 121) \\
\hline XII - Evoluir, explosir (p. 121 - 122) \\
\hline Filologia (p. 123- 143) \\
\hline A lei da intercorrência (p. $123-124)$ \\
\hline $\begin{array}{l}\text { Portugal e Brasil na África - vestígios portugueses nas línguas do ocidente e do oriente } \\
\text { da África - colônias brasileiras na costa ocidental (p. } 125-143 \text { ) }\end{array}$ \\
\hline Notas lexicográficas acêrca de (p. $145-196)$ \\
\hline I - Nomes indígenas de algumas localidades da província de Minas (p. 145 - 149) \\
\hline Nomes indígenas de algumas localidades da província de Minas (p. 150 - 154) \\
\hline Nomes indígenas de algumas localidades da província de Minas (p. 154 - 157) \\
\hline Nomes indígenas de algumas localidades da província de Minas (p. $157-163$ ) \\
\hline II - Alguns nomes tópicos da província do Rio de Janeiro (p. $165-180$ ) \\
\hline III - Alguns nomes tópicos do Paraná (p. $181-196)$ \\
\hline Notas do folclore brasileiro do Sr. Valle Cabral (p. 197 - 200) \\
\hline Estadoal, Estadual, Estatual? (p. 201) \\
\hline Declaracion de La doctrina Cristiana, manuscrito guarani (p. 205) \\
\hline Um manuscrito guarani (p. 207 - 229) \\
\hline Abreviaturas bibliográficas (p. $231-236)$ \\
\hline Índice remissivo de africanismos, indianismos e brasileirismos (p. 237 - 264) \\
\hline Índice Geral (p. 265-269) \\
\hline
\end{tabular}

Nesta obra, é possível encontrar alguns elementos que apontam para o período de produção dos textos (1874-1890), tais como: o patriotismo-nacionalismo presente no estudo das Letras, o status de um estudioso da área, a questão do uso de estrangeirismos 
- para alguns estudiosos da linguagem do período, excessivo - e a incipiência dos estudos sobre o contato do PB com as línguas africanas.

No que se refere ao patriotismo-nacionalismo, é bastante marcante o obituário elogioso que Macedo Soares faz a Batista Caetano ${ }^{5}$ em ocasião de sua morte. Segundo ele, Batista Caetano "queria completar a nossa independência política pela emancipação literária" (Macedo Soares (1942[1874-1890]): 16). Seus trabalhos sobre as línguas ameríndias brasileiras e sobre a língua portuguesa falada no Brasil teriam, portanto, um propósito nacionalista.

Ainda no texto sobre Batista Caetano [1826-1882], obtivemos algumas informações sobre as condições de trabalho do interessado em assuntos linguísticos: Macedo Soares afirma que, na condição de empregado público ${ }^{6}$, Batista Caetano não tinha tempo disponível para se dedicar à produção linguística suficientemente, ainda que tenha sido também historiador. Segundo Macedo Soares, seu interesse pelas línguas africanas não pôde ser aprofundado, por exemplo. Como vimos pelo próprio perfil biográfico de Macedo Soares, essa situação era bastante comum: reflexões sobre a linguagem desenvolviam-se nas horas "vagas" de intelectuais que se dedicavam a outras profissões.

Uma crítica presente na extensão de toda a obra é relativa ao uso de estrangeirismos na escrita do português brasileiro. Macedo Soares também critica o desconhecimento geral sobre o que seria o PB que características teria, bem como a preferência dos brasileiros por usos típicos do PE. Segundo ele, sobretudo a imprensa brasileira e os literatos, potencialmente difusores de uma norma "culta", seriam "representantes do português francelho que se fala e escreve em Lisboa" (Macedo Soares (1942[1874-1890]): 16). Nesta toada, sobre "platô" discute:

Chamam-na, entretanto, e apesar de sua vernaculidade, chamam-na de plató os nossos professores de geografia (com raríssimas exceções). [...] Tal é a miséria literária no Brasil que, para exprimirmos nossas ideias, primeiro nos lembram os termos franceses que os da língua que sentimos mover-se dentro da boca." (Macedo Soares (1942[1874-1890]): 75-6)

Quanto à incipiência dos estudos sobre o português do Brasil, o autor afirma que mesmo os "lexicógrafos brasileiros”, expressão do autor, desconheceriam o PB: “[...]

\footnotetext{
${ }^{5}$ Batista Caetano Almeida Nogueira [Minas Gerais, 1826-1882], estudioso das línguas americanas e da língua portuguesa falada no Brasil.

${ }^{6}$ Não localizamos a informação sobre qual atividade Batista Caetano desempenhava.

7 As marcas em itálico presentes em todos os trechos retirados de Estudos Lexicógrafos do Dialeto Brasileiro são de Macedo Soares.
} 
sobre quem aliás não podemos jurar sem precedente reserva em tudo o que concerne ao dialeto brasileiro" (Macedo Soares (1942[1874-1890]): 57).

Nas análises feitas de itens lexicais específicos, também é comum que Macedo Soares faça observações que apontam o ineditismo de seu trabalho, como no trecho: "MALOCA: aldeia, povoação. Não vem nos léxicos portugueses. Não é da língua geral cujo alfabeto carece da letra $l$, tanto no tupi, como no guaraní. Resta saber se é africana. [...]" (Macedo Soares (1942[1874-1890]): 66).

Em outros momentos, Macedo Soares expõe o seu próprio desconhecimento, ou suas dúvidas, acerca da origem dos termos relativos ao contato do PB com as línguas africanas: "MUGANGA: espécie de abóbora grande. Do bundo nganga? Do guaraní? Deve ser munganga? Moganda?” (Macedo Soares (1942[1874-1890]): 67).

\subsection{2 'Horizonte de retrospecção'}

Quanto ao 'horizonte de retrospeção', Macedo Soares admite tomar como referência os seguintes autores:

[...] Couto de Magalhães, Candido Mendes, Beaurepaire Rohan, Barbosa Rodrigues, Sylvio Romero, Pacheco Junior e outros, que estão formando uma pléiade, pouco numerosa, mas brilhante, de investigadores da língua e da literatura pátria, em seus elementos e suas origens, é que cabia a tarefa que de nossa parte não passa de tentativa apenas para ulteriores e mais acabados trabalhos. (Macedo Soares (1942[1874-1890]): 73) ${ }^{8}$

Os autores mencionados dedicaram-se a estudar as línguas nativas brasileiras e a documentar registros da tradição e cultura oral indígenas, bem como a investigar a história, política e literatura nacionais, além da língua portuguesa e dos "brasileirismos". No trecho acima, Macedo Soares parece compartilhar das preocupações desses autores ou tê-los como modelos.

Dentre todos os citados, Batista Caetano é o mais reverenciado. No mesmo artigo já citado, Macedo Soares lamenta a morte do especialista em "filologia e

\footnotetext{
${ }^{8}$ José Vieira Couto de Magalhães (Diamantina (MG), 1 de novembro de 1837 — Rio de Janeiro (RJ), 14 de setembro de 1898); Cândido Mendes de Almeida (São Bernardo dos Anapurus (MA), 14 de outubro de 1818 - Rio de Janeiro (RJ), 1 de março de 1881); Henrique Pedro Carlos de BeaurepaireRohan (Niterói (RJ), 12 de maio de 1812 - Rio de Janeiro (RJ), 19 de julho de 1894); João Barbosa Rodrigues (São Gonçalo do Sapucaí (MG), 22 de junho de 1842 - Rio de Janeiro (RJ), 6 de março de 1909); Sílvio Vasconcelos da Silveira Ramos Romero (Lagarto (SE) , 21 de abril de 1851 Rio de Janeiro (RJ), 18 de junho de 1914) e Manoel Pacheco da Silva Júnior (1842-1899)
} 
linguística americana" e fundador da "escola da linguística brasileira". Segundo o autor, ele era:

\begin{abstract}
Americanólogo dos mais distintos deste século, e capaz de, só por si, constituir a glória literária do Brasil na segunda metade do século XIX. Entre os antigos, será lícito compará-lo com Anchieta e Montoya; entre os modernos (falamos dos do país), nenhum sombreia com tamanho vulto (Macedo Soares (1942[1874-1890]): 15)
\end{abstract}

No entanto, Batista Caetano não é tido por Macedo Soares como referência nos estudos africanos e de contato. Macedo Soares contesta uma a uma as análises dos termos (do 'angolense') que Batista Caetano questiona serem mesmo de procedência africana. Para Batista Caetano, se tratava de termos do Tupi. Apesar disso, a crítica de Macedo Soares é precedida também de um longo parágrafo elogioso do trabalho e da competência do autor (Macedo Soares (1942[1874-1890]): 44).

Em outros trechos, sobre a discussão a palavra 'tanga', há também um embate: Macedo Soares a toma como do 'bundo ou do congo' e Batista Caetano como do Guarani (ou Abañeē) (Macedo Soares (1942[1874-1890]): 50).

No que se refere especificamente à área de estudos das línguas indígenas, os mais citados são: Montoya, Anchieta, Auguste de St. Hilaire e Figueira ${ }^{9}$, autores de obras fundadoras de descrições de línguas indígenas, como Guarani e Tupinambá e também de descrições da fauna e flora nacionais.

No campo das línguas africanas, Macedo Soares refere-se a Bernardo Maria de Cannecattim, missionário capuchinho italiano ${ }^{10}$, pela Collecção de observações grammaticaes sobre a língua bunda, ou angolense e Diccionario abreviado da lingua congueza (1859, $2^{\mathrm{a}}$ edição), como no trecho em que ele reproduz e discute as palavras africanas de Cannecattim que se aproximariam de 'tanga' (Macedo Soares (1942[18741890]): 52-3).

O 'horizonte de retrospecção' que pudemos mapear em Macedo Soares é, como se vê, difuso, sobretudo quando se trata, especificamente, como pretendíamos verificar, daquele horizonte admitido para tratar do tema do contato do PB com as línguas africanas. Como veremos mais adiante, na seção 4.3.3. 'Fontes', Macedo Soares não

\footnotetext{
${ }^{9}$ Antonio Ruiz de Montoya (Lima (Peru), 13 de junho de 1585 - 11 de abril de 1652); José de Anchieta y Díaz de Clavijo (09 de março de 1534 em Tenerife, Ilhas Canárias (Espanha) - 9 de junho de 1597 em Reritiba, atual Anchieta, Espirito Santo (Brasil)); Augustin François César Prouvençal de SaintHilaire (Orleans (França), 4 de outubro de 1779 - Orleans (França), 3 de setembro de 1853); Luís Figueira (Almodóvar (Portugal), 1574?1575?1576 - Ilha de Marajó, Maranhão (Brasil), 3 de julho de 1643).

${ }^{10}$ Segundo Apontes (2011:84): Cannecattim atuou em missão religiosa por mais de 20 anos com os "[...] abundos do reino de Angola, exercendo a função de missionário apostólico, ex-prefeito das Missões de Angola e Congo [...]".
} 
identifica a origem de seus dados e somente recorre a outros autores para contrastar análises que eles desenvolveram com a sua própria análise, geralmente desqualificando os demais pontos de vista que menciona.

Outra dificuldade está na identificação das próprias referências feitas por Macedo Soares; as informações estão incompletas e excessivamente abreviadas, traço mais ou menos comum em textos do período. Essa característica pode estar relacionada ao pequeno círculo de interessados em língua e linguagem, pretensamente conhecedores de todas as referências relevantes na área. Se for assim, elas se tornavam óbvias para os pares e não precisavam ser detalhadamente explicitadas.

Os autores mais comumente acionados por Macedo Soares, em diálogos convergentes ou polêmicos, são Morais Silva, Constâncio e Frei Domingos Vieira ${ }^{11}$; todos os três lexicógrafos, autores de, respectivamente, Dicionário da Língua Portugueza (1789), Novo Diccionario Critico e Etymologico da Lingua Portugueza (1836) e Grande Diccionario Portuguez ou Thesouro da Lingua Portugueza (18711874).

Dentre os autores mais mencionados que escreveram em língua estrangeira está Max Müller ${ }^{12}$ e a tradução francesa Nouvelles leçons sur la science du langage ${ }^{13}$ (186768). O autor alemão sempre aparece como uma referência a ser dada quando a discussão é sobre mudanças fonéticas, como no trecho: "Ora, a mudança do $c$ forte (com o som de $k$ ) para o $t$ é de fato tão constante que Max-Müller é levado a presumir que, num período mais primitivo dos dialetos gregos, flutuava a pronúncia entre o $k$ e o $t$ " (Macedo Soares (1942[1874-1890]): 54).

Nessa análise, podemos verificar que Macedo Soares privilegia os usos e variação linguísticas, bem como a expressão de uma cultura através da língua em sua descrição do que seria "brasileiro". Também há, naturalmente, traços relevantes de época sobre a argumentação, que também recorre à natureza (clima, questões étnicas) como elemento de relevância para a configuração da língua.

\subsection{3 'Programa de investigação'}

\footnotetext{
${ }^{11}$ Antônio de Morais Silva (Rio de Janeiro, 1 de Agosto de 1757(1755?)-Pernambuco, 11 de Abril de 1824); Francisco Solano Constâncio (Lisboa (Portugal), 24 de Julho de 1777 — Paris (França), 21 de Dezembro de 1846) e Frei Domingos Vieira (? - 1854?).

${ }^{12}$ Friedrich Max Müller [Dessau, Alemanha, 1823- Oxford, Inglaterra, 1900].

${ }^{13} \mathrm{O}$ título completo, que não aparece em Macedo Soares, é "Nouvelles leçons sur la science du langage: cours professé à l'Institution Royale de la Grande-Bretagne en l'année 1863. Phonétique et étymologie: précédé d'une notice sur la vie et les ouvrages de M. Max Müller. Traduit de l'anglais par M. Georges Harris et M. Georges Perrot”.
} 


\subsubsection{1 'Visão de língua'}

Macedo Soares traz reflexões sobre a língua a partir da discussão sobre o status do português falado no Brasil: seria uma língua diferente do português europeu, uma variedade ou dialeto do PE ou uma mesma língua? Essa polêmica a respeito da natureza e do estatuto do PB está demonstrada, inclusive, pela oscilação em denominá-la (Coelho 2012; 2008) ${ }^{14}$. Em muitas passagens, Macedo Soares parece defender a ideia de que o português falado no Brasil já não é o mesmo falado na Península, como nos trechos abaixo (grifos nossos):

a) (1882) Sobre uma possível ortografia próxima da fala: “[...] falamos diferente do português de Portugal” (Macedo Soares (1942[1874-1890]): 17);

b) (1879) Sobre as palavras boava ou emboava: “[...] aforou-se o vocabulário como próprio e exclusivo do dialeto brasileiro" (Macedo Soares (1942[1874-1890]): 27);

c) (1880) Sobre a divergência no uso de galicismos em Portugal e no Brasil, que seria prova da constituição de línguas diferentes: “[...] a língua de lá não é a língua de cá, diferem já quase como a água do vinho" (Macedo Soares (1942[1874-1890]): 86);

d) (1880) Sobre a palavra capoeira: "É curiosa a descrição que dão de capoeira os léxicos portugueses, demonstrando ainda uma vez que a língua brasileira já é alguma coisa diferente da portuguesa, como não podia deixar de ser, atentos os elementos que, desde as primeiras povoações do Brasil, estão influindo para esse resultado" (Macedo Soares (1942[1874-1890]): p. 41);

\footnotetext{
14 Como apresentado em Coelho (2008: 115): "Os nomes do português do Brasil nos Estudos lexicográficos do dialeto brasileiro são: "dialeto brasileiro", "português do Brasil", "linguagem nacional", "língua brasileira", "português falado no Brasil", "português que se fala hoje no Brasil”," "lusobrasileiro", "nosso dialeto", "língua pátria", "dialeto luso -brasileiro", "português da América", "nossa atual linguagem", "brasileiro", "língua portuguesa que se fala no Brasil", "linguagem cá da terra", "nossa língua", "dialeto nacional”, "língua de cá", "língua do Brasil”, "língua portuguesa falada no Brasil”.
} 
e) (1881) Sobre sufixos que adquirem novo sentido no Brasil: "Donde se conclue em favor da maior riqueza do dialeto brasileiro, e, sobretudo, da divergência, bem acentuada, já, que, ainda por este lado, vai afirmando a nossa nacionalidade, quer política, quer literária.” (Macedo Soares (1942[1874-1890]): 112)

Nesses e em outros fragmentos, verificamos que, para Macedo Soares, o português brasileiro (ou, em uma de suas expressões preferenciais, o 'dialeto brasileiro'), ainda que compartilhe a escrita do português europeu, é falado de maneira distinta, havendo já constituído, ao menos, um conjunto de vocábulos próprios. Sobre a expressão 'dialeto brasileiro', ele afirma:

Temos muitas vezes, no correr deste escrito, falado em dialeto brasileiro. Cumpre observar que não apuramos o valor científico da palavra dialeto. Se entendermos por dialeto a linguagem derivada da língua geral de uma nação e particular a uma cidade ou província, o brasileiro não é dialeto do português. Por outro lado, a expressão língua brasileira nos parece demasiado pretensiosa, se se quer com ela distinguir o português falado no Brasil, modificado pelo clima, pela natureza ambiente, pela influência dos elementos africano e indiano, das relações comerciais, etc, do português falado em Portugal. Empregamos como mais modesta a outra expressão, que é ao mesmo tempo menos incorreta, e dá bem entender que nos referimos ao movimento dialetal que visivelmente se está operando na linguagem nacional (Macedo Soares 1942[1874-1890]): 73)

Segundo essa síntese, o português falado no Brasil não seria um "dialeto" do português europeu, pois não é "particular a uma cidade ou província"; no entanto, não é também uma língua autônoma; seria, por outra via, o português europeu modificado pelas condições sócio-históricas aqui encontradas pelo ambiente e pela influência dos "elementos" africano e indígena.

No mesmo sentido, ele também afirma:

[sobre a palavra jaguar] Lembre-nos que a palavra é hoje não mais guaraní só, porem e particularmente brasileira; e embora o português do Brasil se diferencie do português de Portugal, a índole é idêntica, o seu gênio não desaparece; modificam-se as formas léxicas, mas sempre de acordo com as leis fonéticas do idioma primevo, leis que sofrem alterações mais ou menos profundas em virtude do clima, dos usos e costumes, e outras influências geográficas e históricas, mas persistem no seu fundo essencial." (Macedo Soares (1942[1874-1890]): 103).

Macedo Soares propõe que existe uma "índole" comum ao PE e ao PB (ou também "gênio da língua"); assim, possíveis mudanças do PB estariam de acordo com as regularidades previstas no PE, implementadas em vista de elementos étnicos, 
geográficos e históricos, sem, no entanto, romper com o fundo linguístico comum existente entre as duas variedades. A cultura, a geografia e a sociedade teriam ação sobre a língua, de modo a transformá-la em conformidade com sua “índole”. A 'visão' geral de língua é, pois, sociocultural, uma vez que Macedo Soares relaciona fatores externos à constituição da língua, concebida como um objeto naturalmente sujeito à variação.

Parece importante salientar que Macedo Soares nuança sua própria tese de que o PB é distinto do PE; para ele não se tratava de uma questão conclusa. A oscilação na terminologia de nomeação do PB e esses fragmentos em que explora o tema parecem indicar uma reflexão em processo.

Sobre a questão do contato com as línguas africanas, Macedo Soares insiste sobre a vitalidade do uso das palavras de origem africana no PB:

\begin{abstract}
[...] São vocábulos africanos vivos; vivos aquí e na África: introduzidos no Brasil em tempos históricos, e que não vão distantes; falados, ou pelo menos entendidos, por centenas de milhares, quase dois milhões de negros, dos quais parte os articularam n'Angola ou no Congo, parte os tem ouvido da boca de seus pais, parte os vão reconhecer na tradição imemorial da fazenda de seus senhores. (Macedo Soares (1942[1874-1890]): 46)
\end{abstract}

Nesse trecho retirado de "Sobre as palavras africanas introduzidas no português que se fala no Brasil", Macedo Soares revela a atualidade, em sua época, do emprego de palavras africanas ${ }^{15}$ - esse artigo foi primeiramente publicado em 1880. No texto, Macedo Soares também destaca a memória de uma tradição oral de palavras que se perpetuaram por gerações.

\begin{abstract}
Além das palavras africanas que acabamos de estudar há um sem número doutras, populares no Brasil, demonstrando que o elemento negro não deixou de contribuir, posto que mais parcamente ainda que o índio, para a formação do dialeto brasileiro. E que mais podia fazer, atenta a inferioridade da raça, e sobretudo, já não a inferioridade, mas a profunda baixeza de sua misérrima condição social (Macedo Soares (1942[1874-1890]): 60)
\end{abstract}

Macedo Soares afirma que, ainda que considerável e popular, a exata contribuição do contato com línguas africanas na formação do léxico brasileiro era desconhecida. Segundo ele, o aporte africano era menor que o do índio na formação do 'dialeto brasileiro'.

\footnotetext{
${ }^{15}$ Sobre a ‘incidência de análise’ de Macedo Soares ver mais adiante.
} 
Frequentemente, em seus textos, aparecem expressões como: "parece de origem africana", "pode ser", "será angolense?" que indicam a incerteza e hesitação do autor em atribuir origem africana às palavras, como no trecho abaixo:

Qual a origem de maloca? Nem o tupí, nem o guaraní, nem o cayuá, nem o xocrem (bugre dos sertões de Guarápuava), possuem a letra $l$; pode-se dizer que é desconhecida no alfabeto brasílico tão raros são os idiomas que a empregam! Será também palavra africana? Malungo é companheiro, patrício da mesma região, que veio no mesmo cambôi, que sofre o mesmo cativeiro; maloca será reunião de companheiros, de malungos? (Macedo Soares (1942[1874-1890]): 47, nota, grifos do autor).

Para o autor, os estudos sobre as línguas africanas e indígenas, bem como sobre o contato, deviam estar na agenda dos estudiosos de Letras, como o demonstra o trecho abaixo:

\begin{abstract}
Um estudo completo dessas vozes d'África e das tribus indígenas do Brasil seria trabalho, além de curioso, de evidente utilidade, para se conhecer não só a influência que exerceram sobre a nossa sociedade os elementos negro e indiano, como também a direção que vai seguindo a língua portuguesa falada no Brasil em comparação com a falada na metrópole. Muitas delas são ainda comuns a Portugal e ao Brasil; algumas lá ficaram, que nunca foram aquí aceitas; outras, que entre nós afloraram jamais foram ouvidas em Portugal; outras, finalmente, que vieram de Portugal, passaram ou estão passando no Brasil pelas transformações dialetais que denunciam o progressivo desenvolvimento, de todas as línguas. Não será ousadia afirmar que na segunda metade do século XX o léxicon brasileiro não há de ser mais o léxicon português. (Macedo Soares (1942[1874-1890]): p. 72-3).
\end{abstract}

Macedo Soares propõe que esse estudo auxiliaria a conhecer a influência que o contato entre povos e línguas teve sobre a sociedade e sobre o português falado no Brasil. Tal estudo ajudaria ainda a mostrar a que direção as mudanças do PB levariam se comparadas com as que ocorriam no português da antiga metrópole.

Vê-se, também no tratamento desse tema específico, uma 'visão' que privilegia os aspectos sociais e culturais que influenciam na variação constitutiva da língua. 


\subsubsection{2 'Incidência da análise'}

Com a relação à 'incidência da análise', verificamos, pela própria natureza dos textos (estudos lexicográficos), que Macedo Soares observa o contato do PB com as línguas africanas a partir do exame de 'palavras', levando em conta, principalmente, aspectos como seu significado ${ }^{16}$. No entanto, ao lado dos significados, o autor apresenta dados sobre origem das palavras, seus processos morfológicos de formação e seus diferentes contextos de variação (neste último caso, destacando o uso relacionado a aspectos geográficos e históricos, registros orais e escritos, perfil dos falantes e contextos de produção). Vejamos alguns exemplos de sua abordagem do léxico de origem africana usado no Brasil:

a) "DENGO, ndengo: pequeno. T. Bundo, dengue, ndengui. Apelido familiar de menino, o qual temos ouvido em alguns municípios do litoral" (Macedo Soares (1942[1874-1890]): 64). No trecho, como se vê, Macedo Soares destaca o significado, a língua de origem, formas vocabulares originais do termo, situação e local de uso.

b) "GIMBO: dinheiro. Usado só entre os negros e a gentalha. Do bundo zimbu, moeda, dinheiro. Em congo, zimbu, nzimmu." (Macedo Soares (1942[18741890]): 64).

c) "GUZO: força. T. bundo nguzu. Usado só entre negros e gente de sua igualha. Contudo, a um certo senador que discursava aos arrancos e com arrebatada gesticulação chamava o Marquês do Herval, ministro da guerra e senador, "nguzo-sae. Em menino ouvíamos dirigir a negros novos a intimação: "nguzo! Nguzu-sae!", para, saltando com os braços entesados, darem amostra de sua força e robustez física. Desgraçado tempo!” Nguzu-sáe é a phr.: “força tem”. (Macedo Soares (1942[1874-1890]): 64).

\footnotetext{
${ }^{16}$ Macedo Soares defende fazer análise lexicográfica e não etimológica, ver em 'técnica', mais adiante, como ele diferencia essas duas abordagens.
} 
d) "Mucamba é frequente entre os escravos do litoral do Rio de Janeiro (côrte e província) muitas pessoas assim o dizem; mas já Moraes dava mucama como pronúncia do Rio de Janeiro, sendo a da Baía, Pernambuco e outras partes mumbanda, e termo errado macuma" (Macedo Soares (1942[1874-1890]): 47).

e) "MATACO: o assento, as coxas: só usado entre os negros e gente de sua igualha. Do bundo matacataca, pl. de ritacataba, coxa. Em congo bucc'i. É o bundo matacu, traseiro.” (Macedo Soares (1942[1874-1890]): 65).

Nos trechos, como se nota, ao lado das informações relativas aos significados, Macedo Soares destaca o nível de difusão das palavras oriundas do contato: específicas de um grupo (o mais baixo na escala socioeconômica do período) e não comuns no "dialeto brasileiro", ou já estendidas a outros domínios de utilização do PB (linguagem familiar). Observe-se, além desses aspectos, que são considerados fatores como frequência, perfil dos falantes e variações do termo, equivalência entre termos e mesmo entre línguas.

Como já afirmamos, o foco da análise é a 'palavra' vista, sobretudo, da perspectiva do sentido. No entanto, os dados permitem notar que Macedo Soares explora também os níveis fonético-fonológico e morfológico (metaplasmos, processos de composição, terminações, desinências, declinações, entre outros), como no trecho abaixo:

a) "Entretanto, as línguas neo-latinas não admitem as nasais, $m b, n d, n g$, sem que sejam precedidas de vogal. E daí vem que daquelas palavras africanas que ficaram no brasileiro ou perderam a primeira consoante ou tomaram vogal inicial: mbirimbáu ficou birimbau, ou converteu-se em marimbau; ngana passou a angonna; Ngola a Angola; mbaca perdeu o $m$ inicial e ficou baca; mbunda ficou ambunda e também bunda; nbonde passou a anbonde, depois a bonde". (Macedo Soares (1942[1874-1890]): 27)

b) “Antes de tudo, não destoa da índole, nem dos moldes da língua dos abundos e dos congueses já a forma, já a contextura do vocábulo. A sílaba $c a$ é inicial de muitos substantivos e alguns verbos, e sinal de negação nos que, começando por $c u$, de afirmativos se tornam negativos. A terminação inga é regular, como se vê 
em misinga, corda, musinga, disciplina, mixinga, açoites, tiringa, coxear, moquinga, solenidade, mubinga, petição, dinga, ver, vinga, suplicar, etc. Começa por uma só consoante, não tem as duplas senão o $g$ nasalizado, e termina por vogal”. (Macedo Soares (1942[1874-1890]): 57)

Quanto às línguas africanas identificadas, o autor se refere ao "bundo ou angolense" e ao "congo". Às vezes, há referência genérica a "o africano", como nos trechos: "MUCAMA, MUCAMBA é puro africano: macamba, pl. de ricamba [...]" (Macedo Soares (1942[1874-1890]): 46) e "TANGA nos parece tambem termo africano" (Macedo Soares (1942[1874-1890]): 49).

\subsubsection{3 'Fontes'}

Com relação ao levantamento e análise das fontes materiais de dados explorados nos textos, aspecto relacionado com a 'incidência da análise', observamos que há a predominância do uso de fontes cuja origem não é identificada, como no trecho: "BENGALA: bordão, porrete, bastão. Do bundo bangala, congo mbassa, muala." (Macedo Soares (1942[1874-1890]): 61).

A grande maioria dos dados é apresentada dessa maneira, sem identificação de fonte. Mas o autor menciona também como fontes trabalhos de outros autores que exploraram os itens lexicais que ele analisa. Muitos são citados para confrontar as análises que trazem com as próprias explicações de Macedo Soares; entre esses com os quais o autor tende a discordar estão Morais Silva, Frei Domingos Vieira e Constâncio, como exemplificado nos trechos:

a) "BUNDA: nádegas. Moraes presume que venha de binda, t. d'Angola (?); mas no angolense a palavra é tal qual no português. Item, fem. de bundo, angolense, natural do reino de Anbonde ou Angola. Fig., "escrever em língua bunda", escrever em português mascavo; "falar língua bunda", falar mal o português, de modo inteligível, inçando-o de termos e frases estrangeiras”. (Macedo Soares (1942[1874-1890]): 61).

b) “[sobre cambada] Frei Domingos Vieira dá a significação natural de "série de coisas enfiadas numa vara, verga ou cordel", e acrescenta: "fig.: grande 
quantidade, cambada de gente. Toma-se quase sempre um sentido pejorativo: uma cambada de ladrões, uma cambada de patifes". Ora, não há dúvida que muitas vezes se emprega o termo assim, de sorte que desperta a idéia de enfiada; o mais delas, porém, anda só. "Que cambada!", diz um dos nossos partidos políticos ao outro [...]” (Macedo Soares (1942[1874-1890]): 49)

c) Constâncio: [sobre o termo macamba]: “Constâncio, porem, já acrescenta como sentidos figurados estes dois: "grande quantidade de gente ou coisas umas atrás das outras", e "t. de desprezo, gente desprezível, turba"”. (Macedo Soares (1942[1874-1890]): 49).

Outro aspecto que deve ser mencionado quanto às 'fontes' é a incorporação de dados que remetem à própria experiência de Macedo Soares. Nos trechos abaixo, ele adiciona às suas análises dos termos sua própria vivência nas fazendas com negros escravizados e, ainda, a sua circulação em outros estados do Brasil, como o Paraná, em que atuou como juiz. Há também a incorporação das experiências a ele relatadas por terceiros:

a) [sobre o termo tanga] Dessas mantas vimos muitas no Paraná, e possuimos, entre vários curús, um chamado cheripá, feito por uma índia caiuá, o qual nos foi obsequiosamente, e com esse nome, ofertado pelo eminente varão Frei Timoteo de Castelnuevo, Rdm. Vice-Prefeito Apostólico Capuchinho, diretor de aldeamento de São Pedro de Alcântara” (Macedo Soares (1942[1874-1890]): 501)

b) "Como última ratio, consultamos a dous negros muito inteligentes da fazenda da "Gironda", propriedade do nosso parente e amigo Dr. Francisco Belisario, que nos fez a graça de ouví-los. Um é benguela, e o outro moçambique, este fala também o benguela. Ambos afirmam que tanga, tanto na África oriental, como na ocidental, significa o "saiote" em questão. O moçambique pronuncia tâng'ah, o $g$ muito gutural, nasalizado o $1^{\circ} \hat{a}$, e bem aberto, posto que breve, o segundo". (Macedo Soares (1942[1874-1890]): 55, nota 18) 
Parece que ainda não havia um conjunto substancial de trabalhos que tratasse do contato do $\mathrm{PB}$ com as línguas africanas, nem muitos registros de palavras dele resultantes (situação, ao que parece, não muito alterada nos dias atuais); sendo assim, Macedo Soares recorre a outras (poucas) propostas existentes (normalmente para contestá-las, apontando suas fragilidades, de modo a reafirmar suas próprias proposições) ou recorre a um suposto conjunto de experiências, suas ou de terceiros.

\subsubsection{4'Técnica'}

Ao analisarmos o conjunto de princípios e métodos descritivos adotados, ou defendidos na obra, observamos que Macedo Soares insiste em situar seu trabalho como trabalho de natureza lexicográfica e não etimológica. Os trechos abaixo são ilustrativos:

a) "Sem fazer grande cabedal do modo da formação etimológica da palavra emboaba, venha de aba-mbôaé-abá, ou de amôabá, ou amôaba, ou de ambôaéha (part. de aycó ser), o essencial de assentar é a significação lexicográfica". (Macedo Soares (1942[1874-1890]): 29)

b) "Não disputamos com grande afinco sobre a etimologia filológica ou gramatical das palavras; e fique consignado que só damos importância à etimologia filosófica e histórica, indagando os vocábulos, $1^{\circ}$ significado; $2^{\circ}$ a origem filológica, se vem do índio, do negro, do castelhano, ou do português; $3^{\circ}$ seu título de nacionalização brasileira, isto é, se se acha admitido, e como, e porque o foi no dialeto nacional. Aceitamos o vocábulo tal qual o achamos, formado, pronto, representando uma noção clara e distinta: averiguados aqueles pontos, está instruído seu processo lexicográfico”. (Macedo Soares (1942[1874-1890]): 51 , nota)

c) "Notem que não estamos aquí fazendo etimologia; não é nenhum processo filológico, não é a restituição histórica de uma palavra às suas origens, remotas no tempo e no espaço. Nada disto: nossa tarefa se limita a simples indagações de crítica lexicográfica [...]”. (Macedo Soares (1942[1874-1890]): 46). 
A crítica lexicográfica de Macedo Soares consiste na busca do significado das palavras e não na verificação de sua origem. Outro aspecto que observamos em sua técnica, defendida ou aplicada, é a frequente tentativa de formalização de regras e generalizações, como observado nos trechos abaixo:

a) "Em bundo o $r$ soa brando, ainda no começo das palavras, como em guaraní, e em português - entre duas vogais, ex: Araripe. Troca-se muitas vezes pelo $d$; o que também sucede em congo. Ricungu pron. quase como oricongo e vem o ricundu, o círculo, o arco fechado, a circunferência, o qual já sofreu a alteração fonética, trocando o $d$ pelo g. Ricungu é outra coisa, quer dizer "barranco". E aquí vem a propósito perguntar: Não seria possível uma lei de Grimm para as línguas africanas, americanas, polinésias, etc?” (Macedo Soares (1942[18741890]): 46, nota)

b) “A $2^{\text {a }}$ razão para acreditarmos que esse $p$ deve ser $g$ é ter antes de si um $n$. É corrente em linguística que a líquida que nasaliza o b e $p$ é o $m$, e a que antecede o $c$, o $d$ e o $g$ e o $z$ é o $n$. Assim, canpa, se fosse escrito com $m$, campa, nos induziria a afirmar que devia ser camba; sendo, porém, com $n$, ou é canca, ou canda, ou canga, ou canza" (Macedo Soares (1942[1874-1890]): 54)

c) "É possível que grande número desses vocábulos não sejam africanos; em compensação, há ainda muitos outros nos dicionários, de cuja procedência angolana ou conguêsa não é lícito duvidar. Em regra, quando virmos no dialeto brasileiro palavras que não são de conhecida origem portuguesa, começando pelas sílabas $m u, n g a, n g o, n g u, q u i, r i$ (fraco), jin podemos afirmar, si et in quantum, que são africanas: $m u, n, q u i, r$ são as quatro declinações abundantes; e $j i$, a inicial da segunda" Inapropriadamente chamadas declinações, ou antes declinações de forma especial, pois não se distinguem pela terminação, e sim pelas iniciais das palavras”. (Macedo Soares (1942[1874-1890]): 71).

Quanto à metalinguagem utilizada por Macedo Soares, podemos observar que ela se aproxima da adotada em estudos diacrônicos, principalmente nos trechos acima, em que ele trata dos aspectos fonéticos-fonológicos: "troca do $d$ pelo $g$ ", "soa brando", 
"líquida que nasaliza o b e $p$ é o $m$ ", entre outros. Não se trata, no entanto, de metalinguagem muito especializada ou hermética.

No trecho 'c', acima, Macedo Soares tenta formalizar regras que permitem reconhecer palavras de origem africana no 'dialeto brasileiro'. Para isso, ele se aproxima da metalinguagem 'tradicional' nos estudos indo-europeus. No entanto, ainda sobre o termo 'declinação', Macedo Soares estabelece uma correlação com o termo 'classe', de uso mais corrente atualmente nos estudos africanísticos, como no trecho a seguir:

MUCAMA, MUCAMBA é puro africano; macamba, pl. de ricamba, substantivo bundo da $4^{\mathrm{a}}$ declinação (ou antes da $4^{\mathrm{a}}$ classe), como são quibungi, da $3^{\mathrm{a}}$, e mubica, da $1^{\mathrm{a}}$, e todos significam "camarada, servente, criado de servir". Em congo, mubungi". (Macedo Soares (1942[1874-1890]): 46-7)

Cabe afirmar que tal uso da metalinguagem é distinto do de outros estudiosos cujas obras examinamos nesse trabalho, como Raimundo (1933) e Silva Neto (1950) ${ }^{17}$. Neles, o uso da metalinguagem associada aos estudos de línguas indo-europeias, especialmente os de natureza filológica e histórico-comparativa, é mais farto, sistemático. Com o passar do tempo, a metalinguagem parece se tornar mais especializada e a ser empregada com maior consistência. $\mathrm{O}$ uso de uma metalinguagem mais próxima da linguagem corrente e empregada de modo assistemático é aspecto que talvez possamos relacionar à própria formação totalmente autodidata de Macedo Soares e também ao pioneirismo de seus estudos no contexto brasileiro.

\subsubsection{Síntese}

Em conjunto, os resultados da análise aqui esboçada parecem indicar que, a princípio, a obra de Macedo Soares se insere no "programa de investigação" sociocultural, cuja 'visão' fundamenta-se na relação da língua com fatores externos - o PB se distingue por conta da influência das línguas africanas e também das línguas nativas americanas, cuja 'incidência' é sobre dados linguísticos do PB, majoritariamente 'palavras' que variam de acordo com contextos de produção, com aspectos geográficos e históricos, com os registros orais e populares, perfil dos falantes e cuja 'técnica' insere as formas linguísticas em certo contexto (social, étnico e linguístico). Também há a

\footnotetext{
${ }^{17}$ Ver a análise sobre Silva Neto, mais adiante.
} 
discriminação de unidades, o estabelecimento de relações entre formas linguísticas e a postulação de certas 'regras' que remeteriam ao programa 'descritivista'. No entanto, prevalecem os traços de uma abordagem sociocultural, considerados os parâmetros oferecidos por Swiggers (1981a, 1991a, 2004).

Ao que parece, Macedo Soares, como um dos autores que primeiro se preocuparam com a natureza do $\mathrm{PB}$, relacionando-o com o contato com línguas indígenas e africanas, não apresenta ainda um estudo bem definido, uma metodologia mais consciente.

A figura de Macedo Soares não tem destaque na retrospectiva histórica de Bonvini (2009). Nela, Macedo Soares aparece como um dos autores da segunda metade do século XIX, ao lado de João Ribeiro, por sua vez, mencionado por seu Dicionário Gramatical (1897). Segundo Bonvini (2009), Nina Rodrigues, com Os Africanos no Brasil $\left(1932^{18}\right)$, teria tido o mérito de ter formulado o problema do contato do PB com as línguas africanas e teria cabido a Raimundo e Mendonça a formulação da questão da influência lexical. Também outros trabalhos acerca das relações entre o PB e as línguas africanas tendem a iniciar o retrospecto a partir dos trabalhos desses dois estudiosos publicados nos anos 1930. Em vista do que pudemos notar nesta análise, parece-nos, contudo (e apesar do caráter mais intuitivo e menos coeso de suas ideias e técnicas), que é possível reservar a Macedo Soares um capítulo importante na história desses estudos. Examinaremos agora os dois trabalhos mais comumente identificados como fundadores dessa tradição no Brasil: Mendonça (1935[1933]) e Raimundo (1933).

\subsection{A influência africana no Português do Brasil (1935[1933]) de Renato Firmino Maia de Mendonça [1912 - 1990]}

\subsubsection{Breve perfil biográfico e visão geral da obra}

Renato Firmino Maia de Mendonça [1912 - 1990] foi bacharel em Ciências e Letras pelo Colégio Dom Pedro II e professor de língua portuguesa no mesmo colégio. Foi diplomata, pesquisador e historiador. Nasceu na cidade de Pilar (Alagoas) e faleceu no Rio de Janeiro. Concorreu a cargo de diplomata pelo Instituto Rio Branco e empatou com Guimarães Rosa (cf. Sales; Rocha In Mendonça (2012[1935])). Foi fundador da

\footnotetext{
${ }^{18}$ Essa obra de Nina Rodrigues, apesar da data de publicação, teria sido escrita entre 1890 e 1905.
} 
cátedra de Literatura Brasileira na Universidade Nacional do México e ministrou palestras nas Universidades de Coimbra (Portugal) e de Iowa (EUA). Em 1934, recebeu o prêmio de Erudição da Academia Brasileira de Letras e, em 1936, recebeu o Prêmio de Língua Portuguesa da Academia Brasileira de Letras, além de ter também recebido o Prêmio Tasso Fragoso (do Ministério da Guerra). Destacamos esses últimos aspectos porque parecem indicar que Mendonça foi um intelectual destacado e prestigiado em sua época.

A influência africana no português do Brasil foi publicada pela primeira vez em 1933, quando Mendonça tinha 21 anos. Há 6 edições posteriores da obra: a $2^{\text {a }}$ em 1935; a $3^{\mathrm{a}}$ em 1948 (publicada em Portugal), a $4^{\mathrm{a}}$ em 1972 e a $5^{\mathrm{a}}$ em 1973, ambas republicações da $2^{a}$ edição, e a $6^{a}$ de 2012, que foi feita pela FUNAG (Fundação Alexandre de Gusmão, instituição pública vinculada ao Ministério das Relações Exteriores). A frequência com que ela foi republicada sugere que tem sido revisitada de tempos em tempos ${ }^{19}$.

Utilizamos a $2^{\mathrm{a}}$ edição (255 páginas), de 1935, que parece ser a edição consolidada pelo autor e com o maior número de reproduções. Nela há o acréscimo de dois capítulos em relação à $1^{\text {a }}$ edição, a saber: "III - O tráfico" e "VIII - O negro na literatura brasileira". Além disso, são acrescentadas fotografias, novas etimologias na seção de vocabulário e mapas toponímicos ${ }^{20}$.

O texto de Mendonça foi, originalmente, uma monografia apresentada em concurso para a cadeira de português do Colégio Dom Pedro II, dedicada ao Prof ${ }^{\circ}$ Rozendo Martins, um latinista. A obra apresenta prefácio de Rodolfo Garcia [1873 1949] ${ }^{21}$, que destaca o pioneirismo do trabalho. Segundo Garcia, anteriormente só havia os trabalhos de Antônio Joaquim de Macedo Soares [1838 - 1905] e Neves Leão ${ }^{22}$ (citado por Henrique de Baurepaire-Rohan). Garcia classifica o trabalho de Mendonça

\footnotetext{
19 Dois intervalos (as décadas de 1950 a 1960 e 1980 a 2000) não apresentam edições que tenhamos localizado. Interessante notar que a discussão da hipótese de 'crioulização', para Bonvini (2009) concorrente da hipótese de 'influência', tenha circulado no país justamente nesses dois momentos de ausência de reedições da obra, seja em textos como Silva Neto (1950), em que ela é formulada, seja em textos como Tarallo (1993[1986]), em que ela é posta em questão.

20 Outra obra de repercussão do mesmo autor foi O português do Brasil - Origens - Evoluções Tendências (1936), “dedicado a Antenor Nascentes, Affonso D’Escragnole Taunay, Rodolfo Garcia, Mario Marroquim e Clovis Monteiro que tanto têm analisado a evolução da língua portuguesa no Brasil" (Mendonça 1936).

21 Rodolfo Augusto de Amorim Garcia (Ceará-Mirim (RN), 1873 - Rio de Janeiro, 1949) foi um historiador e intelectual brasileiro. Foi membro do Instituto Histórico e Geográfico Brasileiro e da Academia Brasileira de Letras, além de diretor do Museu Histórico Nacional e da Biblioteca Nacional.

${ }^{22} \mathrm{Na}$ obra de Raimundo (1933), ele é caracterizado como "profundo conhecedor do ioruba, que falava e escrevia" (Raimundo 1933: 96). Ainda não localizamos outras informações sobre esse autor.
} 
como um estudo sobre a "influência que as línguas africanas tiveram no português falado no Brasil”" (cf. Garcia In Mendonça 1935[1933]: 11).

Além desse prefácio, a obra contém um "Vocabulário" (p. 167-247), um “Apêndice - Opiniões da crítica sobre este livro” (p. 249-250), um “AddendumExplicação dos mapas toponímicos pelo Prof. Carlos Marie Cantão ",23 (p. 251-255) e os seguintes capítulos:

\begin{tabular}{|l|}
\hline I. Etnografia Africana (p. 27-34) \\
\hline II. Linguística Africana (p. 35-49) \\
\hline III. O tráfico (p. 51-74) \\
\hline IV. Povos negros importados (p. 75-84) \\
\hline V. Fonética e Morfologia do Quimbundo (p. 85-100) \\
\hline VI. Influência Africana no Português (p. 101-124) \\
\hline VII. Folclore - Totemismo e Feitiçaria (p. 125-150) \\
\hline VIII. O Negro na Literatura Brasileira (p. 151-166), \\
\hline Quadro 4.2: Estrutura da obra A influência africana no Português do Brasil (1935[1933])
\end{tabular}

É no capítulo “Influência Africana no Português” que Mendonça (1935[1933]) procura sistematizar as contribuições das línguas africanas ao português falado no Brasil. O autor explora os diferentes níveis de articulação: fonético, fonológico, morfológico, lexical e sintático.

Mendonça afirma que seu objetivo é apresentar "um trabalho que vem incorporar aos estudos sôbre as alterações do português do Brasil e deseja ardentemente contribuir para a independência e cultura do idioma nacional" (Mendonça 1935[1933]:16). Em seu texto, fazem-se presentes alguns temas relevantes no período (cf. entre outros, Pinto 1978, 1981) como, por exemplo, o da denominação e do estatuto da língua portuguesa falada no Brasil.

\footnotetext{
${ }^{23}$ Carlos Marie Cantão foi bacharel em Direito pela Faculdade de Direito da Universidade do Brasil e licenciado em Geografia pela Faculdade de Filosofia, Ciências e Letras da antiga Universidade do Distrito Federal. Professor de Geografia do Colégio Pedro II, professor Titular de Geografia Física da Pontifícia Universidade Católica do Rio de Janeiro, professor de Geografia Econômica do Brasil da Fundação Getúlio Vargas, professor Associado de Geografia Humana da Faculdade de Filosofia, Ciências e Letras do Instituto Santa Úrsula.
} 
Segundo Mendonça, esse tema gerava polêmica, porque não havia consenso sobre o que era a 'língua brasileira'. Seu objetivo era criar uma 'codificação' (termo de Mendonça) das mudanças no PB que não fosse motivada pelo entusiasmo do nacionalismo brasileiro, "embora fosse para nós motivo de orgulho dizer, no estrangeiro, que temos uma literatura e uma língua brasileira. Em suma que falamos brasileiro". (Mendonça 1936: prefácio).

Enquanto escritores, filólogos e estudiosos prefeririam as denominações "nosso idioma", "língua nacional" e "o idioma nacional", Mendonça utiliza os termos brasileiro, língua brasileira, português do Brasil, português brasileiro.

Mendonça declara o interesse em divulgar às massas os dados a que chegasse no empreendimento de 'codificação' de peculiaridades do PB, uma vez que "nada possa interessar mais o nosso povo do que a sua própria língua", e entendia que o desenvolvimento do PB apontava para a configuração de um novo idioma:

A expressão do brasileiro, a emissão dos sons, a pronúncia característica, o vocabulário corrente, a própria coordenação das palavras na frase representam a feição própria, cada vez mais acentuada, de um novo idioma. (Mendonça 1936: prefácio).

\subsection{2 'Horizonte de retrospecção'}

Ao que parece, Mendonça compartilha das preocupações de uma geração que buscou descrever e explicar as características do português brasileiro como pode ser revelado pela maioria dos autores e obras citadas em seu texto de forma positiva (obras que compõem, portanto, seu 'horizonte de retrospecção') ${ }^{24}$ :

Nina Rodrigues (1862-1906) por Os africanos no Brasil (1933)

Edgar Roquette-Pinto (1884-1954) por Seixos Rolados (1927)

Leite de Vasconcelos (1858-1941) por Esquisse d'une dialectologie portugaise $(1901)$

\footnotetext{
${ }^{24} \mathrm{O}$ autor apresenta uma "Bibliografia" que contém uma lista de 79 "livros aproveitados neste estudo e julgados de maior importância". No entanto, consideramos como para a análise os autores e obras efetivamente citados ao longo do texto, de forma positiva, no que diz respeito ao contato do PB com as línguas africanas e a natureza do Português falado no Brasil. Consideramos como 'horizonte de retrospecção', como vimos anteriormente, o conjunto de obras com as quais o texto em análise dialoga, seja de forma convergente, seja de forma conflitante ou polêmica. Nesse fragmento da análise, destacamos o conjunto das obras às quais o texto de Mendonça se alinha.
} 


\begin{tabular}{|c|}
\hline $\begin{array}{l}\text { Franco de Sá (1841- 1906) por A língua Portuguesa (dificuldades e dúvidas) } \\
\text { (1915) }\end{array}$ \\
\hline $\begin{array}{l}\text { Rodolfo Garcia (1873-1949) por Dicionário de Brasileirismos (peculiaridades } \\
\text { pernambucanas) (1915) }\end{array}$ \\
\hline Virgílio de Lemos (1863-1926) por A língua portuguesa no Brasil (1959[1916]) \\
\hline $\begin{array}{l}\text { Antenor Nascentes (1886-1972) por } O \text { idioma nacional (1927) e O linguajar } \\
\text { carioca (1922) }\end{array}$ \\
\hline Mário Marroquim (1896-1975) por A língua do nordeste (1934) \\
\hline Amadeu Amaral (1875-1929) por O dialeto caipira (1920) \\
\hline $\begin{array}{l}\text { Macedo Soares (1838-1905) })^{25} \text { por Dicionario Brazileiro da Língua Portuguesa } \\
\text { (1889), autor que é citado por Mendonça como o precursor dos estudos sobre o } \\
\text { tema. }\end{array}$ \\
\hline
\end{tabular}

Quadro 4.3: Horizonte de retrospecção de Mendonça 1935[1933]

\subsection{3 'Programa de investigação'}

\subsubsection{1 'Visão de língua'}

Em Mendonça (1935[1933]), a língua é vista pela ótica das relações entre sociedade e cultura, ancoradas na noção de contato étnico e linguístico. Como vimos em citação anterior, Mendonça afirma que o PB constitui-se como um dialeto do PE e sofre um processo evolutivo de diferenciação em relação a ele. O 'dialeto brasileiro', também denominado 'brasileiro', 'língua brasileira', 'português do Brasil', 'português brasileiro' apresentaria subdialetos, ou seja, variedades (sociais ('popular, culto') e regionais ('caipira', 'da cidade')).

A diferenciação do dialeto 'brasileiro' não resulta apenas das coerções geográficas e climáticas, mas também da contribuição indígena e africana: instaura-se uma perspectiva que considera o modo de constituição da história do povo como

\footnotetext{
${ }^{25}$ Raimundo Nina Rodrigues (Vargem Grande (MA), 1862 — Paris, 1906), Edgar Roquette-Pinto (Rio de Janeiro, 1884 - Rio de Janeiro, 1954), José Leite de Vasconcelos Cardoso Pereira de Melo (Ucanha, Tarouca, Portugal, 1858 - Lisboa, 1941), Filipe Franco de Sá (Alcântara (MA), 1841 Alcântara (MA), 1906), Rodolfo Augusto de Amorim Garcia (Ceará-Mirim (RN), 1873 — Rio de Janeiro, 1949), Virgílio Da Silva Lemos (Alagoas, 1863 - Salvador, 1926), Antenor de Veras Nascentes (Rio de Janeiro, 1886 - Rio de Janeiro, 1972), Mario Marroquim (Água Preta (PE), 1896 Maceió (AL), 1975), Amadeu Ataliba Arruda Amaral Leite Penteado (Capivari (hoje MonteMor), 1875 - São Paulo, 1929) e Antônio Joaquim de Macedo Soares (Maricá (RJ), 1838 - Rio de Janeiro, 1905).
} 
responsável pela mudança linguística. $\mathrm{O}$ autor considera esse aporte como fundamental e insuficientemente aprofundado, principalmente no que se refere ao papel das línguas africanas.

Quanto às línguas africanas faladas pelos sete milhões de negros escravizados vindos ao Brasil, segundo estimativa de Mendonça (1935[1933]: 73), ele enumera: nagô ou iorubá, quimbundi, gêge ou ewe, tapa ou nife e guruncis. Entre elas, teriam atuado como "línguas gerais" o nagô ou iorubá, na Bahia, e o quimbundo no norte e no sul do país; o autor faz essa afirmação remetendo-se à posição de Nina Rodrigues e outros (1935[1933]: 84). Os povos que teriam predominado em termos geográficos seriam os nagôs na Bahia, os congos em Pernambuco e angolas nos estados do Rio de Janeiro e São Paulo.

Sobre a existência de línguas crioulas no Brasil, ele afirma: "No Brasil, deve ter havido dialetos crioulos em diversos lugares da colônia. Tiveram, porém, existência muito instável e cedo desapareceram" (Mendonça 1936: 111).

Para Mendonça, o estudo das transformações linguísticas que provocavam a diferenciação do dialeto brasileiro em relação ao PE era urgente e constituía um programa de estudos de uma geração. Nesse sentido, critica a ausência de trabalhos de natureza dialetológica e a predominância de estudos que privilegiam a pesquisa de 'assuntos lusitanos', atrelados ao campo da filologia.

Outro aspecto fortemente criticado pelo autor é a ausência de distinção entre fenômenos de origem indígena e africana em alguns estudos, ou mesmo a atribuição de contribuições notadamente africanas às línguas nativas brasileiras. Segundo ele,

\footnotetext{
Isto resulta da proeminência indevida que se conferiu ao índio com prejuízo do negro na formação da nacionalidade brasileira. Há mesmo aí muita coisa influenciada pelo indianismo de Gonçalves Dias e Alencar. O negro que sua no eito e, esfalfado, trabalha sob o chicote, não oferece a mesma poesia do índio aventureiro, que erra pelas florestas.... (Mendonça 1935[1933]: 109)
}

Tal constatação, no entanto, não faz o autor deixar de reconhecer a participação das línguas indígenas na formação do português brasileiro, que teria, no entanto, sido exageradamente valorizada pelos estudiosos em detrimento do contributo negro.

A 'visão de língua' sustentada por Mendonça está em consonância com a hipótese de que é possível descrever e explicar a emergência e as mudanças no PB com recurso aos contatos étnicos e linguísticos, sendo a língua deles resultante um patrimônio da nação. Importantes intelectuais entre o final do século XIX e as 
primeiras décadas do $\mathrm{XX}$ dedicaram-se a refletir sobre o tema, como o demonstra o conjunto de obras referidas em seu texto.

\subsubsection{2'Incidência'}

As análises que Mendonça realiza reportam-se a usos linguísticos regionais ("interior" do país) e socioculturais (porque relativos a estratos específicos da sociedade), como o autor faz notar no seguinte trecho em que menciona aspectos da morfossintaxe do português do Brasil: "O vestígio mais notável acha-se no plural conservado pela linguagem dos caipiras e matutos, que deixando o substantivo invariável, dizem sempre: as casa, os caminho, aquelas hora." (Mendonça 1935[1933]: 119-120, grifos do autor).

Também nas considerações de caráter mais geral, o autor privilegia determinadas variedades da língua, como a 'popular': "O negro influenciou sensivelmente a nossa linguagem popular. Um contato prolongado de duas línguas sempre produz em ambas fenômenos de osmose" (Mendonça 1935[1933]: 113).

Mendonça reconhece, no entanto, que esses usos linguísticos diferenciados devido ao contato com o elemento negro estão presentes também na linguagem culta (incluída a literária), como nas seguintes passagens:

\footnotetext{
[a respeito do $r$ do infinitivo dos verbos] mesmo na linguagem culta do Brasil, o $r$ final soa levemente. (Mendonça 1935[1933]:116)

[a respeito da redução dos ditongos] Em Pernambuco e Alagoas, mesmo a gente letrada só pronuncia quêjo, mantêga, fêjão, dêxe (M. Marroquim, $A$ língua do nordeste) (Mendonça 1935[1933]: 118-119) ${ }^{26}$
}

Os traços seriam característicos da linguagem menos prestigiada, mas afetariam também os domínios de prestígio ("mesmo na linguagem culta", "mesmo a gente letrada").

Os níveis de articulação privilegiados na análise do PB - principalmente na modalidade popular, influenciado por línguas africanas - são o fonético-fonológico e o lexical.

\footnotetext{
${ }^{26}$ A referência completa da obra citada por Mendonça é: MARROQUIM, Mário. A Língua do Nordeste (Alagôas e Pernambuco). Companhia Editora Nacional, 1934.
} 
Ao lado da contribuição genérica e imprecisa que deu o africano para o alongamento das pretônicas e a elocução clara e arrastada, deixou sinais bem seus nos dialetos do interior, principalmente. (Mendonça 1935[1933]: 112)

Em Pernambuco e Alagoas, os negros deixaram certos adjetivos no dialeto local:

capiongo cassange

cafuçú ingangento

cangúlo macambuzio [...] (Mendonça 1935[1933]: 121)

A influência africana sobre a sintaxe e a morfologia do PB seria, segundo o autor, menor:

Na morfologia o negro deixou apenas vestígios o que é explicável pela diferença profunda entre as línguas indo-europeias e africanas. (Mendonça 1935[1933]: 119)

Na sintaxe, a influência africana é ainda menos sensível. （Mendonça 1935[1933]: 123)

\subsubsection{3'Fontes'}

Com relação às 'fontes', ou seja, a origem dos dados linguísticos apresentados, observamos que são consultados por Mendonça (1935[1933]):

\section{- Produções literárias:}

"[sobre a redução] Este tratamento aparece até na linguagem literária. Raimundo Correia fez a rima beijo, desejo no soneto Madrigal: "Te hão de roubar meus sôfregos desejos/Mas o vento o chapéu lhe arroja aos ares:/A ave, liberta assim, voa... e com ela/Lá se foram também todos os beijos...". (Mendonça 1935[1933]: 118, grifos do autor).

\section{- Repertório popular tradicional:}

"O fonema línguo-palatal $t h$ muda-se na semivogal y: Dizem que a muyé é farsa/Tão farsa como papé,/Mas quem matou Jesus-Cristo/Foi home, não foi muyé (quadra popular do sul de Goiaz)" ((Mendonça 1935[1933]: 112, grifos do autor)

\section{- Outros trabalhos que abordam o tema:}

"Antes de $e$ e $i$, o $g$ transforma-se esporadicamente $z$ no dialeto carioca, o que pode ser um vestígio do africano: genebra $\rightarrow$ zinebra / registro $\rightarrow$ rezistro (A. Nascentes, O linguajar carioca, p. 32)" (Mendonça 1935[1933]: 114, grifos do autor) 
Além desses três conjuntos de fontes, o autor por vezes recorre a dados sem origem identificada: "Dissimilação. Ocorre nos grupos consonânticos de elocução difícil: negro $\rightarrow$ nego / alegre $\rightarrow$ alegue" (Mendonça 1935[1933]: 114, grifos do autor)

\subsubsection{4 'Técnica'}

Partindo da premissa de que contato motiva a mudança linguística, Mendonça tenta mapeá-la a partir de um conjunto de princípios e métodos descritivos que prevê a inserção do fato linguístico na perspectiva da evolução social.

Acompanhando dados da história social, o autor assinala que, à medida que a presença negro-africana cresce no Brasil, a indígena vai desaparecendo. Tal mudança no cenário étnico nacional é acompanhada também de uma transformação na esfera linguística: "Esta transformação étnica reflete-se na esfera linguística, e a língua acompanha a raça na sua evolução. Língua e raça formam dois elementos que têm evolução paralela a ponto de serem muitas vezes confundidos" (Mendonça 1935[1933]: 110).

Essa perspectiva, segundo Christino (2001:18), era predominante no período entre 1920 e 1945 nos estudos linguísticos no Brasil, que consideravam o contato entre 'raças' como o principal motor da mudança linguística.

O método descritivo adotado por Mendonça visa a demonstrar as modificações sofridas pelo $\mathrm{PB}$, principalmente em suas modalidades mais populares, a partir do impacto das línguas africanas (com destaque para o quimbundo e o iorubá) em diferentes níveis linguísticos, mas com privilégio de dados fonético-fonológicos e lexicais, como vimos anteriormente. Em geral, o autor propõe uma formulação geral (que leva em conta as dimensões social e linguística do fenômeno) e, em seguida, arrola uma série de exemplos comprobatórios daquilo que afirma, como nos seguintes casos:

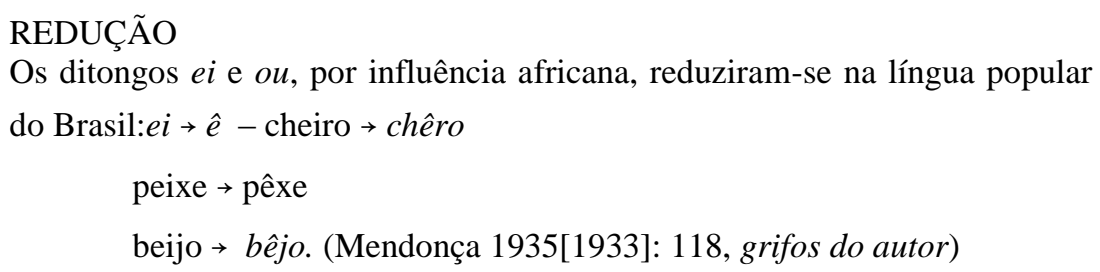

Há certas locuções que foram introduções vulgarizadas no português graças ao negro: angu-caroço, angu-de-negro, banzé-de-cuia, bodum-azedo, azeitede-dendê, dendê-de-cheiro. (Mendonça 1935[1933]: 122, grifos do autor). 
A metalinguagem privilegia termos que, embora também correntes em abordagens sincrônicas, são comuns em estudos diacrônicos, tais como: redução, dissimilação, suarabácti. Também a apresentação gráfica dos dados, com recorrente emprego de setas direcionadas da esquerda para a direita, reforça a pressuposição de comparação entre um estágio original (o português tal como falado na Europa e introduzido no Brasil) e um estágio modificado pela influência africana:

$$
\begin{aligned}
& \text { chegar } \rightarrow \text { chega } \\
& e i \rightarrow \hat{e}-\text { cheiro } \rightarrow \text { chêro }
\end{aligned}
$$

Com o mesmo intuito de mapear a origem de fatos de destaque no PB de sua época, Mendonça ainda realiza comparações com outras línguas, tais como:

\section{- Línguas crioulas na África:}

"A queda do $r$ final aparece também nos dialetos crioulos da África: cabo-verdiano - onde às vezes cai: chegar $\rightarrow$ chegá da ilha de S. Tomé - onde às vezes cai: cuié em vez de colher [...]" (Mendonça 1935[1933]: 115, grifos do autor)

\section{- Línguas românicas:}

[sobre a vocalização] "romeno - a antiga consoante $l$ molhado reduziu-se no Norte a $y$ semivogal: foais $\rightarrow$ folia, fiu $\rightarrow$ filiu, muiere $\rightarrow$ muliere" (Mendonça 1935[1933]: 113, grifos do autor)

\section{- Línguas africanas:}

[sobre o suarabacti no quimbundo] "Justifica esta nossa hipótese o tratamento semelhante que sofrem os grupos consonânticos entre os angolenses que falam o quimbundo: "Rodolfo $\rightarrow$ Rodolofu / Cristovão $\rightarrow$ Kirisobo / Cristina $\rightarrow$ Kirixina" (Mendonça 1935[1933]: 117, grifos do autor)

\subsubsection{Síntese}

Em conjunto, os resultados da análise aqui apresentada parecem indicar que a obra de Mendonça se insere no 'programa de investigação' sociocultural, cuja 'visão' fundamenta-se na relação da língua com fatores externos - o contato entre falantes de diferentes línguas gera a mudança linguística e a variação linguística, cuja 'incidência' é sobre dados linguísticos do PB (especialmente das variedades menos prestigiadas 
(mas também das prestigiadas)) e dados sociais correlacionáveis à mudança, à variação linguística e à determinação dos usos linguísticos, cuja 'técnica' insere o fato linguístico na perspectiva da evolução social, vista como um conjunto de múltiplas coerções (as origens genéticas da(s) língua(s), as características do contato étnico e linguístico, seu contexto (social, étnico, linguístico) de desenvolvimento, sua preservação em grupos), e cujas 'fontes-objeto' são diversificadas, indo das literárias às do repertório popular tradicional. A reconstrução do 'horizonte de retrospecção', ancorado em obras e autores que também refletem tais preocupações, parece corroborar essa nossa classificação do texto.

\subsection{O elemento afro-negro na língua portuguesa (1933), de Jacques Raimundo Ferreira da Silva [ ?- 1960?]}

\subsubsection{Breve perfil biográfico do autor e visão geral da obra}

Jacques Raimundo Ferreira da Silva foi professor do Colégio Dom Pedro II e do Instituto de Educação, ambos no Rio de Janeiro e membro do Conselho Nacional de Ensino e da Academia Carioca de Letras. Segundo a Revista da Academia Fluminense de Letras $^{27}$ (Niterói, 1949-1976), ele teria sido dado como desaparecido em 09 de novembro de 1960. Foi também fundador do Botafogo Football Club, em 1904, no Rio de Janeiro, atuando como secretário na primeira diretoria, conforme informações do site oficial do clube ${ }^{28}$. Além de $O$ elemento afro-negro na língua portuguesa (1933), Raimundo publicou O negro brasileiro e outros escritos (1936) e A língua portuguesa no Brasil. (Expansão, penetração, unidade e estado atual) (1941).

O elemento afro-negro na língua portuguesa (1933) está organizado como segue:

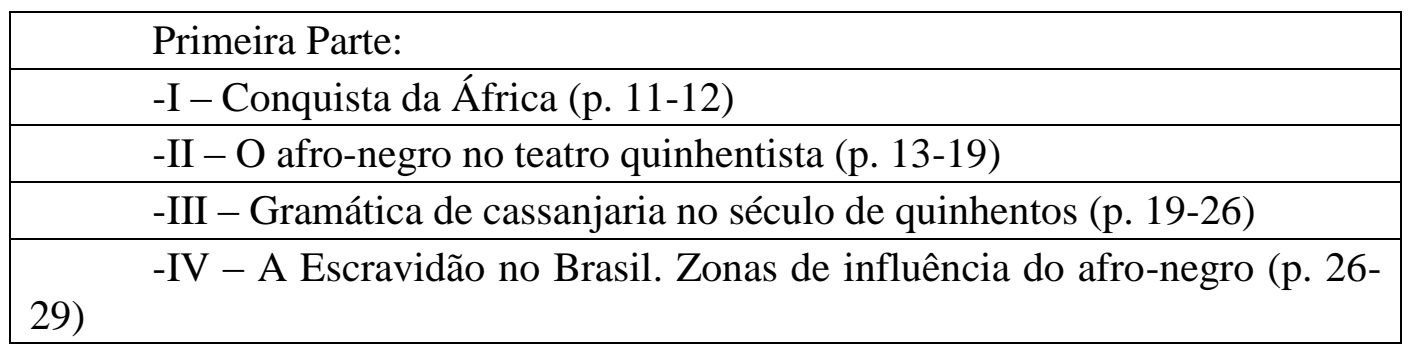

\footnotetext{
${ }^{27}$ Revista da Academia Fluminense de Letras, volumes 11-14, 1960, p. 263.

${ }^{28}$ Localizamos poucas informações biográficas sobre o autor.
} 


\begin{tabular}{|l|}
\hline -V - Afro-camíticos e sano-hotentotes (p. 29-31) \\
\hline -VI - Povos guineano-sudaneses (p. 31-37) \\
-VII - Povos e idiomas afro-bantos. Principais línguas guineano- \\
sudanesas (p. 37-43) \\
\hline -VIII - Necessidade do conhecimento das línguas afro-negras (p. 43 - 44) \\
\hline -IX - Notas gramaticais do ioruba. Fonética ioruba-portuguesa (44-49) \\
\hline -X- Notas gramaticais do banta (p.49-66 ) \\
\hline -XI - A linguagem do escravo no Brasil (p. 66-72) \\
\hline -XII - A acutização dos vocábulos bantas no Brasil (p. 72 - 74) \\
\hline -XIII - Fonética banto-portuguesa (p.74-75) \\
\hline -XIV - Lexeologia guinéo-sudânico-portuguesa (p. 75-77) \\
\hline -XV - Lexeologia banto-portuguesa (p. 77 -) \\
\hline -XVI - Novas criações banto-portuguesas (p. 80 - 85) \\
\hline -XVII - Criações banto-portuguesas. Traducionismo. (p. 85 - 87) \\
\hline Segunda Parte \\
\hline -Vocabulário (p. 89-179) \\
\hline -Bibliografia (p. 181-191) \\
\hline Quadro 4.4: Estrutura da obra O elemento afro-negro na língua portuguesa (1933)
\end{tabular}

\subsection{2 'Horizonte de retrospecção'}

A reconstrução do 'horizonte de retrospeção' do autor em $O$ elemento afronegro da língua portuguesa foi dificultada pela ausência de um prefácio, em que o autor explicite suas preferências teóricas e também em virtude das poucas referências bibliográficas presentes no decorrer do texto. Em sua obra, localizamos as seguintes referências ${ }^{29}$ :

\begin{tabular}{|c|}
\hline Fernando Ortiz y Fernández [1881-1969] \\
\hline Cláudio Filipe de Oliveira Basto [1886 - 1945] \\
Geira (1529) \\
\hline Raimundo Nicente (c. 1465-c. 1536?) por Frágua de amor (1524) e O clérigo da \\
\hline Cancioneiro d'Ajuda
\end{tabular}

\footnotetext{
${ }^{29}$ Citamos aqui todas as referências de Raimundo e não somente as relativas ao contato do PB com as línguas africanas e a natureza do Português falado no Brasil devido ao número pequeno e à forma imprecisa de fazer referências no texto.
} 


\begin{tabular}{|l}
\hline Hermenegildo Carlos de Brito Capelo (1841-1917) e Roberto Ivens \\
(1850-1898) por De Benguela às Terras de Iaca (1881) \\
\hline $\begin{array}{l}\text { F. W. Kolbe por A language-study based on Bantu or an Inquiry into the } \\
\text { Introduction to the Study of Herero and Bantu in General (1883) }\end{array}$ \\
\hline João Ribeiro (1806-1934) pelo Diccionário Gramatical \\
$(1906[1888 / 1889])$ \\
\hline Vicente García de Diego (1878-1988) por Contribución al Diccionario \\
Hispano Etimológico (1923)
\end{tabular}

Quadro 4.5: 'Horizonte de retrospecção' de Raimundo (1933) ${ }^{31}$

Ao final do livro, Raimundo apresenta uma bibliografia com "Obras de informação e Vocabulários", "Línguas da Guiné e do Sudão" e "Línguas bantas". No entanto, consideramos para análise as referências efetivamente mencionadas ao longo do texto (cf. Quadro 4.5). Dentre as obras mencionadas, somente a de João Ribeiro, Diccionário Gramatical (1906[1888/1889]) trata especificamente (e em alguma medida) do contato do Português Brasileiro com as línguas africanas ${ }^{32}$ : “[...] concordância por prefixação de 'z: zêre z'mandou z'dizê, eles mandaram dizer. (J. Rib. Dic. Gram. 222)" (Raimundo 1933: 72, grifos do autor).

O texto é dedicado a Fernando Ortiz y Fernandéz [1881-1969] caracterizado por Raimundo como "publicista, folclorista e afrinigólogo cubano, ilustre sob todos os aspectos" (dedicatória), "eminente publicista, professor da Universidade de Havana, nosso amigo e nosso mestre" (Raimundo 1933: 92), cuja produção intelectual dirigiu-se ao estudo da influência negra na cultura cubana, nas perspectivas linguística e antropológica. Esse autor cubano publicou obras como Glossário de Afronegrismos (1924) e La africanía de la música folklórica de Cuba (1950) e criou a Sociedad del

\footnotetext{
30 Fernando Ortiz y Fernandéz [Havana, Cuba, 1881 - 1969], Cláudio Filipe de Oliveira Basto [Viana do Castelo, Portugal, 1886 - 1945, Carcavelos, Portugal], Gil Vicente (Portugal, c. 1465 - c. 1536?), Raimundo Nina Rodrigues (Nina Rodrigues (hoje), Vargem Grande (antes), Maranhão,1862 - 1906, Paris, França), Hermenegildo Carlos de Brito Capelo (Portugal, 1841 - 1917), Roberto Ivens (Portugal, 1850 1898), F. W. Kolbe, João Batista Ribeiro de Andrade Fernandes (Laranjeiras, Sergipe, 1860 - Rio de Janeiro, 1934) e Vicente García de Diego (Espanha, 1878-1978).

${ }^{31}$ Algumas das referências encontradas no texto estavam incompletas, sem o nome da obra ou data. Sendo assim, procedemos do seguinte modo: buscamos completá-las com as informações contidas nas referências bibliográficas do próprio autor ou com informações que sabíamos previamente.

${ }^{32}$ A referência a Nina Rodrigues é sobre a vinda dos negros para o Brasil: povos e número de indivíduos escravizados e não propriamente sobre aspectos linguísticos.
} 
Folklore Cubano (1923), a Institución Hispanocubana de Cultura (1926) e Sociedad de Estudios Afrocubanos (1937). O texto de Raimundo é também dedicado a Cláudio Filipe de Oliveira Basto [1886 - 1945], etnógrafo e filólogo português, Francisco Adolfo Coelho [1847 - 1919] e José Leite de Vasconcelos [1858 - 1941], autores de estudos literários, dialetológicos e de filologia portuguesa.

O 'horizonte de retrospeção', ao que parece, não se trata do mesmo detectado na obra de Mendonça (1935[1933]), anteriormente analisado, ainda que ambos tenham publicado seus estudos no mesmo ano (1933), na mesma cidade, e tenham sido professores no mesmo Colégio (Dom Pedro II). Nessa comparação, destacamos que, em Raimundo, a discussão sobre o carácter do PB ligada aos estudos dialetológicos que começavam a se desenvolver no país está ausente; também não se manifesta, aqui, o desejo de Mendonça de distanciar-se dos trabalhos ditos filológicos.

\subsection{3 'Programa de investigação'}

\subsubsection{1 'Visão de língua'}

À diferença de Mendonça (1933), que foca sua análise nas mudanças do português causadas pelas línguas africanas a partir de um componente externo (o contato étnico), Raimundo não inclui aspectos contextuais em sua análise linguística. Ele menciona certos aspectos nas seções em que trata da história dos povos africanos e sua vinda para o Brasil. Ou seja, ele admite que o contato seja o motivador da mudança linguística; no entanto, essa premissa não implica a consideração de fatores externos nas análises que realiza. A análise atém-se aos dados linguísticos, vistos como autônomos.

Segundo Raimundo, no início do século XIX, quase dois milhões de negros escravizados teriam vindo para o Brasil (Raimundo 1933: 28). Portugal e Brasil teriam recebido os mesmos povos africanos, que ele distribui em dois grupos: guineanosudaneses e bantos. Com segurança, de acordo com Raimundo, teriam vindo os seguintes povos: iorubás; bornus ou caruris; haussás; tapas ou nifês ou nufês; efés ou evés; minas; mandingas ou mandês; sussus; crus, craos ou crâ̂s; gibis ou queás; cameruns; adamauás; bassas ou baças. As línguas ('idiomas', na metalinguagem do autor) que teriam tido maior impacto no português falado no Brasil seriam: “[...] $O$ ioruba, de pronunciadas afinidades com o efé, e os do Congo, de Angola, de Moçambique" (Raimundo 1933: 43, grifos do autor). 
Outro traço diferenciador entre esses dois textos contemporâneos é que a interferência do elemento negro na língua portuguesa é concebida, em Raimundo, como algo negativo; observemos, como exemplo, o trecho abaixo, em que Raimundo avalia o português falado pelos negros:

\begin{abstract}
A sua meia-língua é uma sorte de geringonça ou jerga, em que os vocábulos de aquém do mar se deturpam, se adulteram, se desfeitiam, estropeando-se ou adiantando-se aos sons e sílabas, entrecortadas estas muitas vezes, permutados aqueles outras tantas, o amanho das frases, o regime dos verbos, a situação dos termos e das palavras tudo se altera. Com o tempo innovam-se ou criam-se vocábulos pelo conúbio de idiomas, como surdem(sic) outros afixos. (Raimundo 1933: 67-8)
\end{abstract}

\title{
4.3.3.2 'Incidência da análise'
}

Com relação à análise do $\mathrm{PB}$, há menos variedades mencionadas do que em Mendonça (autor que, como vimos, distingue usos marcados social e regionalmente); verificamos, em Raimundo, somente duas menções à 'fala popular' e à 'frase popular'; seus contrapontos ('fala culta' / 'frase culta') não aparecem:

\begin{abstract}
A escassez do documento escrito, a não ser limitado de modo sem dúvida imperfeito por autores de obras regionais, a remotidade da época da escravatura, não havendo já sequer um remanescente afro-negro, empecem sobremaneira a eficácia da pesquisa e observação para se determinar a influência do escravo no foneticismo e na fala popular. Todavia, estamos certos de que o negro contribuiu grandemente para os modificar na América." (Raimundo 1933: 72-73; grifo nosso)
\end{abstract}

A influência das línguas sul-africanas não se restringiu apenas á copiosa importação de vocábulos primários e derivados; alargou-se ainda que escassamente á própria sintaxe, actuando de preferência no amanho da frase popular que resiste á polícia gramatical" (Raimundo 1933: 85; grifo nosso)

Afora essas duas ocorrências, menções às variedades específicas do PB (linguagem de caipiras e outros grupos) não estão presentes. Ao que parece, ele toma o PB como um bloco único, o que parece apontar para uma visão de língua mais condizente com a do 'programa de investigação descritivista' (ver mais adiante).

Mendonça restringe-se à análise do PB, mobilizando autores brasileiros que se dedicaram a estudá-lo; já Raimundo analisa também a influência de línguas africanas no Português Europeu, como vemos nos capítulos: "O afronegro no teatro quinhentista" e "Gramática de cassanjaria no século de quinhentos", e para tanto recorre a textos literários de Gil Vicente, considerados por ele como "documentação relevante para o 
apreço das alterações que experimentaria posteriormente o português do Brasil sob a influição imediata do negro" (Raimundo 1933: 15). Segundo ele, os textos de Gil Vicente são "[...] fiel o arremêdo da linguagem do negro, por exacto o registro dos vocábulos fonéticamente e das construções solecizadas”. (Raimundo 1933: 17).

Ainda que o autor destaque a interferência africana no domínio lexical, a descrição de Raimundo, tal como a de Mendonça, procura apontar fatos relativos a todos os níveis de análise linguística, porque ele também parece reconhecer a presença africana em todos eles, como se vê, por exemplo, na justificativa do estudo gramatical das línguas africanas como um todo:

\begin{abstract}
O conhecimento, em resumo, do mecanismo gramatical das línguas afronegras que mais cooperaram para o aumento do léxico português, fez-se necessário como prova que se sobreveste de importância. A sua fonética é de tão grande interêsse como a do latim, fonte de sobrepujante cópia vocabular do idioma nacional. A morfologia ministra fundamentos valiosos para o esclarecimento da origem de muitos vocábulos em que aglutinaram dois ou mais elementos africanos, [...], mas não se sobrexecele tanto o trato com a sintaxe, cuja influência rara ou escassamente se faz sentir em boleios e giros da linguagem de entre o povo, avalassando em vez o meio familiar [...] $\mathrm{O}$ conhecimento do vocabulário é de suma relevância, estudado por classes e apontadas as novas criações conforme a índole e o modelo do vernáculo" (Raimundo 1933: 43)
\end{abstract}

As formas linguísticas estudadas estão principalmente no domínio fonéticofonológico (o autor privilegia o estudo dos metaplasmos) e lexical (visto o "Vocabulário" apresentado com 90 páginas), mas ele procura também dar conta de fenômenos dos demais níveis de análise:

\begin{abstract}
A influência das línguas sul-africanas não se restringiu apenas á copiosa importação de vocábulos primários e derivados; alargou-se, ainda que escassamente, á própria sintaxe, actuando de preferência no amanho da frase popular que resiste á polícia gramatical. [...] b) $\mathrm{O}$ uso generalizado do presente do indicativo no futuro do mesmo modo; c) o emprego preferencial de estar com por ter, que é o vernáculo e clássico: aquela mulher está com (tem) febre, etc. [...] (Raimundo 1933: 85, grifos do autor)
\end{abstract}

Em outro trecho, a respeito do português falado pelos negros, também podemos observar a predileção de Raimundo pelos aspectos fonético-fonológicos: a "fonética" apresenta 26 apontamentos de modificações, enquanto há somente 9 referentes à "Morfologia, sintaxe e registro de vocábulos".

\title{
4.3.3.3 'Fontes'
}


Raimundo lamenta a ausência de documentação relativa aos povos vindos para o Brasil e, consequentemente, também sobre as línguas que falavam; também se queixa da ausência de registros que comprovem a influência africana no PB:

\begin{abstract}
A escassez do documento escrito, a não ser limitado de modo sem dúvida imperfeito por autores de obras regionais, a remotidade da época da escravatura, não havendo sequer um remanescente afro-negro, empecem sobremaneira a eficácia da pesquisa e observação para se determinar a influência do escravo no foneticismo e na fala popular. Todavia, estamos certos de que o negro contribuiu grandemente para os modificar na América. (Raimundo 1933: 73)
\end{abstract}

Figuram como fontes em sua obra textos de Gil Vicente, em que se representa a fala do negro. Segundo ele, "a linguagem do Negro que Gil Vicente ilustrou, incluindoo entre os personagens de seu teatro, é uma amostra ou antecipação de como seria a do escravo importado para o Brasil" (Raimundo 1933:67). Valendo-se dessa fonte, Raimundo elabora uma lista de alterações linguísticas de como poderia ter sido o português falado pelos negros em Portugal, dividida em:

- Fonética: “c) troca do $g$ em $b$, seguido de vogal ou de $r$ : abora (agora), consabrado (consagrado)" (Raimundo 1933: 20, grifos do autor);

- Metaplasmos: “a) prótese: acontente (contente), aliás, entre o povo já era corrente o verbo acontentar. Agarba (soma do artigo: a barba)" (Raimundo 1933: 21, grifos do autor);

- Morfologia: “a) Pronomes pessoais: $m i$ e $a m i$ (eu), em função recta; tu (te) e elle (o), em função acusativa" (Raimundo 1933: 22, grifos do autor);

- Sintaxe: "Emprego das formas oblíquas tônicas do pronome pessoal, regidas ou não da prep. $a$, em vez das formas rectas: não sabe mi essa carreira, mi não fala zombaria, como mi saba primeiro, a mi falla guiné, a mi abre oio, quando a mi more de fome, etc." (Raimundo 1933: 23, grifos do autor)

- Vocabulário: “Caralasão: caso interessante de aglutinação, após a qual se operou a metátese já apontada (qual a razão); deve-se também registrar que está empregado substantivamente: hum caralasão" (Raimundo 1933: 25, grifos do autor).

Raimundo considera essa proposta de sistematização como:

[...] o registro imperfeito para se avaliar como devera ter sido, na primeira metade do século de quinhentos e nos cinquenta anos imediatamente anteriores e posteriores, a linguagem do africano, brutalmente adaptado ao 
meio luso-europeu, com reminiscências ou vagas saudades do idioma natal". (Raimundo 1933: 25-26).

No entanto, observamos que a grande maioria dos dados mobilizados na análise de Raimundo é de origem não identificada, tal como as generalizações que ele estabelece:

d) o $r$ inicial asperiza-se e o medial mantém-se fraco, passando a forte raramente;

e) o $j$ inicial ou medial, soando $d j$, passa como $j$, ou permuta-se em $z$ e às vezes em $x$ (ch) (Raimundo 1933: 74, grifos do autor)

\section{ADJETIVOS:}

i) Assinalando côr, actos, estados, etc. aça (assa), bamba, bambambã, banguela, cacório, cambembe, cambondo, catete, cutuba, dunga, jiota, macambúzio, macota, manzanza, mazombo, quiba, zerêe, etc". (Raimundo 1933: 79, grifos do autor)

Chama atenção a referência, praticamente ausente, a outros estudos linguísticos. A ausência desse tipo de fonte também reforça a percepção de que predominam, em sua obra, dados cuja origem não é clara ou explicitada pelo autor.

\subsubsection{4'Técnica'}

Com relação aos métodos descritivos adotados, Raimundo, mais afeito a uma análise baseada na abordagem histórico-comparativa, apega-se à apresentação de muitos exemplos dados a partir da apresentação de uma característica mais ou menos geral: "Troca do $d$ por $r$, possivelmente depois de permutado com $l$ : riabo (diabo), reos (deos), condiro (escondido), firalgo (fidalgo), rinheiro (dinheiro), rise (disse), sapantaro, sesuro (sesudo), toro (todos), turo (tudo)". (Raimundo 1933: 20, grifos do autor)

A análise de Raimundo privilegia, como mencionamos, o apontamento de metaplasmos: "1. Troca do o pretónica em $u$ : nutiça (notícia), fugar (afogar). 2. Alargamento da vogal tónica ou craseada: p'atrais (para atrás), ais vêis (às vezes)" (Raimundo 1933: 69, grifos do autor) ${ }^{33}$.

Tal como em Mendonça, a metalinguagem utilizada é aquela tradicionalmente usada em estudos diacrônicos; a diferença entre os dois autores está no fato de que em Raimundo, esse modo de apresentação e análise dos dados é mais farto e sistemático. Na seção destinada à descrição de línguas africanas, Raimundo adota a técnica de

${ }^{33}$ Trecho referente à análise do português falado pelos negros africanos. 
compará-las com o português, como no seguinte exemplo: “[sobre o ioruba] Há sete vogais: $a, e, e h, i, o h, u$. Usamos do $h$ posposto, por nos faltarem sinais próprios ou melhor adequados; $e h$ profere-se semelhante ao nosso $e$, acusado ou aberto, e $o h$ entre o nosso ó ou ditongo au.[...]" (Raimundo 1933: 44).

\subsubsection{Síntese}

Em conjunto, a análise de 'visão, incidência, técnica' parece indicar que as preocupações de Raimundo são de cunho mais descritivista, se contrapondo aos interesses mais socioculturais observados em Mendonça. A questão da influência não está, neste segundo caso, sendo tratada da perspectiva de construção de valores nacionais ou pátrios e nem sendo desenvolvida a partir do estudo concomitante da língua e das questões de uma história etno-cultural brasileira. Assim, em Raimundo, a 'visão' parece indicar a percepção da língua como objeto autônomo. A 'incidência' recai sobre a estruturação das formas, com destaque para a concepção da língua como todo mais unificado do que diversificado (sem variedades sociais e regionais relevantes, não muito distinto do PE, como vemos, por exemplo, em seu estudo sobre a 'gramática cassange', a partir dos textos de Gil Vicente). Como 'técnica', o autor privilegia o estabelecimento de classificação para os fatos, a determinação de contextos, a segmentação e a comutação de unidades equivalentes. Quanto às 'fontes', são predominantemente de origem não informada. O 'horizonte de retrospecção' que conseguimos depreender revela-se diverso do de Mendonça 1935[1933].

\subsubsection{Síntese comparativa de Mendonça (1935[1933]) e Raimundo (1933)}

As descrições e análises sobre as obras de Mendonça (1935[1933]) e Raimundo (1933) levam às seguintes considerações: Mendonça parece estar em diálogo direto com outros estudiosos da linguagem brasileiros que, antes ou contemporaneamente a ele, se preocupavam em examinar a questão da formação do português do Brasil em uma perspectiva que levasse em conta o contexto. A análise permite afirmar que preocupações de caráter sociocultural predominam em sua obra, na qual o elemento externo, isto é, a mudança no panorama étnico e social, é gerador da mudança linguística. Sua abordagem põe em destaque que a alegada 'influência' africana não se 
restringe ao léxico, mas se estende a todos os níveis linguísticos, ainda que em menor grau, sendo observada nos fenômenos de concordância nominal, invariabilidade de gênero e número e em mudanças fonético-fonológicas. Sua obra denota que as fontes documentais para a pesquisa foram, ainda que se possam fazer ressalvas, variadas.

Quanto à obra de Raimundo, nota-se que não há um apelo à causa dialetológica nacional e o 'horizonte de retrospeção' parece contemplar estudos produzidos fora do Brasil (Portugal, Cuba), além dos já prestigiados estudos de Nina Rodrigues e João Ribeiro. Do ponto de vista da incidência, predomina preocupação com a descrição dos fenômenos linguísticos, tomados autonomamente, como, por exemplo, na explicitação de mudanças fonéticas mais ou menos sistemáticas. Tal como Mendonça, Raimundo explora dados de todos os níveis de articulação linguística ao desenvolver seu estudo.

Resumidamente, desejamos ressaltar que reconhecemos aspectos que parecem diferenciar esses dois textos que têm sido considerados como da mesma tradição. A sua forma de lidar com o contato entre o português e as línguas africanas é distinta, até mesmo numa perspectiva geográfica: no caso de Raimundo, é clara a ênfase sobre o que teria se processado em Portugal, sendo o que aconteceu no Brasil uma espécie de decorrência. Também é preciso dizer que os textos de Mendonça e Raimundo têm sido classificados como excessivamente lexicalistas na exploração da relação entre o PB e as línguas africanas em termos de 'influência'; nossa análise, contudo, não confirma esse traço.

\subsection{Introdução ao estudo da língua portuguesa no Brasil (1950), de Serafim da Silva Neto (1917-1960)}

\subsubsection{Breve perfil biográfico do autor e visão geral da obra}

Serafim Pereira da Silva Neto (Rio de Janeiro, 1917 - 1960) foi um filólogo de grande projeção na área dos estudos da linguagem com uma produção intelectual vasta e diversificada. Iniciou sua carreira precocemente aos 18 anos e logo se tornou referência para os estudos linguísticos de sua época. Foi considerado como um líder intelectual e organizacional (nos termos de Murray, 1994). Alguns de seus trabalhos, como o selecionado para esta análise, alcançaram bastante prestígio e, seja para endosso ou para 
desconstrução, têm sido bastante citados nos estudos sobre a formação do português do Brasil $^{34}$.

Ele concluiu em 1934 o curso colegial (no Colégio Batista do Rio de Janeiro) e ingressou na Faculdade de Direito. Em 1939, foi aprovado em concurso com a tese Divergência e convergência na evolução fonética, tomando posse da cadeira de língua portuguesa no Liceu Nilo Pessanha (de Niterói). Foi professor do ensino secundário e em faculdades de Letras. Atuou também em centros de maior destaque como a Universidade de Lisboa (1958-1960), que lhe conferiu o título de doutor Honoris Causa, a Universidade Católica do Rio de Janeiro e a Faculdade Nacional de Filosofia da Universidade do Brasil ${ }^{35}$. Grande empreendedor, articulou projetos como a criação da Revista Brasileira de Filologia e do Centro de Estudos em Dialetologia Brasileira, no Museu Nacional.

Em 1957, Silva Neto publicou: História da língua portuguesa, considerada por alguns revisores como sua principal obra. Nela, há um capítulo em que ele retoma boa parte das reflexões registradas na Introdução ao estudo da língua portuguesa no Brasil.

A obra Introdução ao estudo da língua portuguesa no Brasil (1950) de Serafim da Silva Neto está organizada como apresentamos no Quadro 4.6 abaixo:

\begin{tabular}{|l|}
\hline Prefácio (p. 3-4) \\
\hline Introdução (p. 5-11) \\
\hline A língua portuguêsa no Brasil (p. 13-30) \\
\hline Diferenciação e unificação do Português no Brasil (p. 31-86) \\
\hline As três fases da história da língua portuguesa no Brasil (p. 87-119) \\
\hline Contato e interação linguística no Brasil colonial (p. 121-164) \\
\hline Panorama atual da língua portuguesa no Brasil (p. 165-223) \\
\hline Do método de pesquisa dos falares brasileiros (p. 225-247) \\
\hline Duas palavras sôbre a língua literária (p. 249-286) \\
\hline Índice (p. 287) \\
\hline
\end{tabular}

Quadro 4.6: Estrutura da obra Introdução ao estudo da língua portuguesa no Brasil (1950)

\footnotetext{
${ }^{34}$ Para um estudo mais amplo da produção intelectual do autor, confira, entre outros, Coelho (1998).

${ }^{35}$ Respectivamente, em 1942, com 26 anos, como catedrático fundador da cadeira de Filologia Românica na Universidade Católica do Rio de Janeiro e, em 1957, com 39 anos, como catedrático de Filologia Românica na Universidade do Brasil.
} 
Silva Neto descreve a sua obra como um ensaio, em que traça "a evolução da língua portuguesa nas terras de Santa Cruz" por meio da "evolução social do Brasil" (Silva Neto 1950: 8). O fio condutor de todos os capítulos é a história: “[...] foi meu escopo encontrar apoio na história do Brasil, na formação e crescimento da sociedade brasileira, para colocar a língua no seu verdadeiro lugar: na expressão da sociedade, inseparável da história da civilização". (Silva Neto 1950:5).

O autor lamenta a inexistência, segundo ele, de um trabalho amplo sobre a "história e etnografia brasileiras" (Silva Neto 1950:5). A Introdução ao estudo da língua portuguesa no Brasil se inseriria nesse campo, ainda que ele admita suas dificuldades em história nacional: "Alguns espíritos superficiais e infecundos podem julgar que faço obra apressada. Mas é que alguém precisa começar - e não veja pressa e assalto à notoriedade onde só existe zêlo e amor ao estudo.” (Silva Neto 1950:8).

Ele critica os filólogos que ainda não teriam se dedicado a esse estudo:

Nota-se ainda que, até hoje, os nossos filólogos só se têm ocupado com peculiaridades regionais e comparações entre as pronúncias lusitana e brasileira. E, assim mesmo, é fôrça confessar que a maioria dêsses trabalhos se deve a amadores e, portanto, deixa muito a desejar [...] (Silva Neto 1950: $6)$.

Ainda que tais estudos regionais na área de dialetologia brasileira fossem necessários para a constituição do panorama que ele pretendia apresentar:

[...] é imprescindível organizar excursões lingüístico-etnográficas para devassar o interior brasileiro e recolher amplos materiais. Antes dessas tarefas não é possível chegarmos a conclusões gerais, sólidas. Faltar-nos-á o material em que esteemos a doutrina (Silva Neto 1950: 6).

Haveria duas perspectivas no campo dos estudos da história da língua portuguesa: “[...] a história externa, de cunho etnográfico-social, e a história interna, que é pròpriamente a dialetologia, de cunho filológico-lingüístico.” (Silva Neto 1950: 6, grifos do autor). Silva Neto classifica a sua obra como do primeiro tipo, um "resumo de história externa da língua portuguêsa no Brasil”' (Silva Neto 1950: 6).

Nessa perspectiva 'externa' em que Silva Neto se insere, o estudo dos contatos étnicos e linguísticos ganharia mais peso e importância:

A matéria de história da língua portuguêsa no Brasil há de investigar-se na etnografia e na evolução histórico-social do povo brasileiro [...] Mas é preciso frisar a muito maior complexidade do caso brasileiro, em vista das particularidades de nossa formação étnico-social (Silva Neto 1950: 7). 


\subsection{2 'Horizonte de retrospeção'}

O 'horizonte de retrospecção' de Silva Neto é bastante complexo, uma vez que ele mobiliza em sua obra uma centena de autores e obras, seja discutindo as propostas ou recomendando a leitura completa dos próprios textos. Seria possível realizar um trabalho completo somente a partir da análise dos autores e da bibliografia mencionados em sua obra. Optamos por apresentar os que parecem ter mais relevância, fator indicado pelo destaque dado a eles por Silva Neto em seu texto.

Desde logo, é possível agrupar os autores mais mencionados por Silva Neto nos seguintes grupos de temas: a) Filologia e Linguística geral, b) português brasileiro e c) contato linguístico do português brasileiro com as línguas africanas:

a) Na área de Filologia e Linguística Geral, compõem o 'horizonte de retrospeção': Ferdinand de Saussure pelo Cours de linguistique générale $(1916)^{36}$; Charles Bally pelo Traité de Stylistique française (1909); Antoine Meillet pelo La méthode comparative en linguistique historique (1925); Joseph Vendryes pelo Le langage: Introduction Linguistique a L'histoire (1921), Edward Sapir por Language: an introduction to the study of speech (1921) e por Dialect $(1931)^{37} \mathrm{e}$ Albert Dauzat por La geographie Linguistique (1922) ${ }^{38}$.

b) Sobre o português brasileiro, destacamos a avaliação que Silva Neto dos trabalhos de dois autores que selecionamos para esta dissertação: Macedo Soares e Renato Mendonça, ainda que eles não sejam mencionados por seus trabalhos a respeito do contato do $\mathrm{PB}$ com as línguas africanas.

Sobre Macedo Soares, Silva Neto discorda da proposta de uma nova ortografia, que aquele autor menciona no obituário de Batista Caetano como uma proposta própria, e escrita mais "brasileiras": "Não se pode, portanto, levar inteiramente a sério aquêle conselho de Macedo Soares: “Já é tempo dos brasileiros escreverem como se fala no Brasil, e não como se escreve em Portugal” (Dicionário Brasileiro, prólogo)" (Silva Neto 1950: 19). Em Estudos Lexicográficos do Dialeto Brasileiro (1942[1874-1890]), ao menos, não há propriamente uma proposta ortográfica para $\mathrm{o} \mathrm{PB}$, mas $\mathrm{o}$

\footnotetext{
${ }^{36}$ O Curso não é citado nominalmente, mas as referências a Saussure e aos conceitos de 'parole', 'langue', entre outros nos indicam que se trata mesmo do Curso.

${ }^{37}$ Provavelmente um verbete na Encyclopedia of Social Sciences (Macmillan), v. 5, p. 123-126, $1931 \mathrm{c}$. (cf. levantamento bibliográfico da dissertação de Cunha (2012)).

${ }^{38}$ Ferdinand de Saussure (1857-1913), Charles Bally (1865-1947), Antoine Meillet (1866-1936), Joseph Vendryes (1875-1960), Edward Sapir (1884-1939) e Albert Dauzat (1877-1955).
} 
reconhecimento de que o PB é distinto do PE, pois no Brasil, fala-se de um modo diferente e há também um conjunto de vocábulos próprios. Segundo Macedo Soares, o que uniria as duas variedades seria a norma adotada na escrita, na qual, indevidamente, predominariam os padrões de uso europeu. A escrita no Brasil, segundo o autor, deveria incorporar aquilo que havia de mais comum na fala local. Por exemplo, o autor não vê sentido em escrever-se "Estar à janela", quando todos falariam "Estar na janela".

No que se refere a esse tema, contrariamente, Silva Neto defende o papel nivelador da escrita, e usa esse nivelamento como argumento a favor da unidade entre o PB e o PE e, em suma, da sociedade luso-brasileira. A língua escrita:

[...] por seu caráter conservador e tradicional, está acima de tôdas as variedades sociais e regionais, dominando e absorvendo tudo. Ela é uma seleção, uma escolha para a qual concorrem as pessoas mais finas e mais cultas da sociedade luso-brasileira (Silva Neto 1950: 19).

A respeito de Renato Mendonça, Silva Neto concorda com Antenor Nascentes que: "Obras gerais, como as tentativas dos Srs. Renato Mendonça e Cândido Jucá Filho ainda são prematuras pois os estudos ainda se acham longe de estar findos" (Estudos filológicos, pág. 152)." (Silva Neto 1950: 7) ${ }^{39}$.

Em outra passagem, Silva Neto concorda com a crítica de Amado Alonso (18961952) ao autor:

In Revista de Filologia Hispanica - I, III, 1941, páginas 58-9.Vj.: Falta la necesaria distincion entre la lengua culta general y lenguajes regionales e locales, entre la lengua oral de los cultos y las modalidades plebeyas; todos los valores parecen haberse deslocado (lo plebeyo vale más que lo culto, lo local más lo general, etc.), en el afan de hacer valer lo diferencial solo por ser diferencial. (Silva Neto 1950: 10, nota 8).

c) Sobre o contato do PB com as línguas africanas:

Silva Neto também crítica Renato Mendonça, e aqueles a quem ele teria arrastado, quando o assunto é contato:

É chocante a fantasia do Sr. Renato Mendonça, quando assevera que o quimbundo também nos "transmitiu algumas peculiaridades da sua fonética e da sua morfologia" (O português do Brasil, pág. 178). Por êle, foi arrastado o corifeu dos estudos negros, Arthur Ramos, quando escreve: “... a difusão do ioruba no português e a influência sofrida por este, de retorno, da morfologia e da fonéticas iorubas" (As culturas negras no Novo Mundo, 1946, página 297). E noutro passo igualmente infeliz: "Foi ainda o quimbundo o responsável mais direto pelas alterações fonéticas, morfológicas e sintáticas

\footnotetext{
39 Antenor Nascentes (1886-1972) deve se referir aqui à obra O português do Brasil - Origens Evoluções - Tendências (1936) de Renato Mendonça.
} 
sofridas pela Língua Portuguêsa no Brasil” (idem, pág. 345)” (Silva Neto 1950: 129).

Silva Neto refere-se no trecho à obra de Renato Mendonça intitulada $O$ português do Brasil (1936). Mais extenso que A influência africana no Português do Brasil; nela, Mendonça discute a natureza do PB com mais profundidade, não somente a partir do contato com línguas africanas, mas também em suas relações com a história, geografia e cultura nacional, além de compará-lo com outras variedades do português. Nesta dissertação, examinamos o texto de Mendonça mais diretamente relacionado à tradição de estudos cujo desenvolvimento desejamos acompanhar.

Arthur Ramos também teria errado ao concordar com Renato Mendonça quanto à atribuição ao contato com as línguas africanas de mudanças nos aspectos fonéticos e morfológicos do português brasileiro. Por outro lado, Silva Neto elogia o mesmo texto de Renato Mendonça, quando ele trata do contato "com o Tupi":

Bastará reler esta extraordinária afirmação de Renato Mendonça: "Esta e
outras observações sôbre os fatos linguísticos levaram o grande tupinólogo a
afirmar que 'o português do Brasil está irremediavelmente (sic) modificado
pelo tupi". Tinha razão nosso produtivo estudioso da etnografia
indígena. O tupi responde por numerosas e profundas alterações na antiga
língua lusa (O Português do Brasil, 159) (Silva Neto 1950: 130, grifos do
autor).

Outro autor que já analisamos também compõe o horizonte de Silva Neto: Jacques Raimundo, este é apenas citado por conta de suas descrições sobre a fala do negro a partir de textos de Gil Vicente ${ }^{40}$. São de leitura recomendada por Silva Neto: $O$ Elemento afro-negro da língua portuguesa $(1933)^{41}$, Negro Brasileiro e outros escritos (1936), além de um artigo na Revista Filológica (volume II). Silva Neto avalia as representações da fala do negro em Gil Vicente:

Certamente êsses trechos não são um primor de observação filológica, pois deve haver, neles, dose bem grande de fantasia. Entretanto contêm alguma verdade, porque muitos câmbios fonéticos que aí observamos encontram-se também nos dialetos crioulos. (Silva Neto 1950: 40).

Silva Neto lista trabalhos da mesma natureza de Jacques Raimundo, em que se poderia descobrir algumas características da 'linguagem dos negros', ainda que não houvesse uma transcrição exata (Silva Neto 1950: 40).

\footnotetext{
${ }^{40}$ Como Farsa do Clérigo da Beira (1529) e Frágua de Amor (1524).

${ }^{41}$ Sobre a qual apresentamos uma análise nesse Capítulo.
} 
Em outro trecho, o autor também recomenda a leitura da obra Problemas da linguagem portuguesa ${ }^{42}$ para aqueles que desejam saber mais acerca das normas do PE antigo sobre a colocação pronominal.

Silva Neto apresenta também um repertório de obras e autores sobre a história do contato no contexto brasileiro, por exemplo, Melville Herskovits; Gilberto Freyre por Casa Grande e Senzala (1933) e Sobrados e Mocambos (1936); Pedro Calmon por História da Civilização Brasileira (1935); Frei Vicente do Salvador pela História do Brasil (1627); História do Brasil (1935), de João Ribeiro, e Arthur Ramos, por A aculturação negra no Brasil (1942) ${ }^{43}$.

Ele elege Hugo Schuchardt ${ }^{44}$, filólogo comparativista alemão que estudou as línguas românicas, crioulas e a língua basca, como "o mais claro e profundo" dentre os estudiosos do contato de línguas. Na citação destacada por Silva Neto, Schuchardt defende a amplitude do contato linguístico entre indivíduos por meio de "empréstimos", "imitações" e "influência estrangeira", seja no âmbito de línguas diferentes ou no de falares próximos.

Silva Neto o menciona ao considerar os contatos entre línguas como um "jogo de interações em sentidos opostos" (Silva Neto 1950:133), em que a estrutura social vigente determinaria a direção da ação de uma sobre a outra ${ }^{45}$.

\subsection{3 'Programa de investigação'}

\subsubsection{1 'Visão de língua'}

Silva Neto expõe a sua visão de língua ao se contrapor ao modo que, segundo ele, se estudava a língua na época. Para Silva Neto, as bases para o estudo do PB ainda

\footnotetext{
${ }^{42}$ Obra atribuída por Silva Neto a Jacques Raimundo, cuja data desconhecemos.

${ }^{43}$ Melville Jean Herskovits (1895 - 1963, EUA), autor de "The negro in Bahia, Brazil: a problem in method" (1943), em American Sociological Review, v. VIII, no 4, p. 394-402; Gilberto de Mello Freyre (Recife, 1900 - 1987), Pedro Calmon Moniz de Bittencourt (Amargosa, Bahia, 1902 - Rio de Janeiro, 1985), Frei Vicente do Salvador (nascido Vicente Rodrigues Palha) (Matuim, 1564 - Salvador, c.1636), João Ribeiro (Laranjeiras, Sergipe, 1860-1934), Arthur de Araújo Pereira Ramos (Pilar, atual Manguaba, Alagoas, 1903 - 1949, Paris).

${ }^{44}$ Hugo Ernst Mario Schuchardt (1842 - 1927).

${ }^{45}$ Ele afirma que a elite brasileira e a língua portuguesa, na sociedade colonial, estavam mais suscetíveis a influência das classes sociais inferiores e das línguas africanas. Essa influência da massa, termos de Silva Neto, se dava em virtude do status cultural e social do negro.
} 
não haviam sido constituídas: a língua não era um bloco, era necessário investigá-la em suas diferentes modalidades e usos. A maioria dos estudos que se dedicaram ao PB apresentariam falhas por não terem essa concepção de língua.

1) O português do Brasil não é um todo, um bloco uniforme. É preciso distinguir-lhe os vários matizes, de acôrdo com as ocasiões, as regiões e as classes sociais. Assim, temos: 1) uso literário, culto; 2) uso corrente (familiar, popular, gíria); 3) uso regional (Silva Neto 1950: 9, grifos do autor)

Ainda que o trecho abaixo seja longo, nele, podemos verificar outros pressupostos que guiam a "visão de língua" em toda a obra:

2) Os colonizadores vinham de tôdas as partes de Portugal, de modo que, em contato e interação, se fundiram num denominador comum, de notável unidade.

3) Acompanhando o destino dos homens, o português primeiro se fincou no litoral. Aí se constituiu, nos dois primeiros séculos da colonização, um falar de marcante unidade, uma koiné, em suma. E foi nessa koiné, falada na costa, que invadiu o interior com as bandeiras e estradas.

Daí, evidentemente, as raízes das características do português brasileiro: a unidade e a arcaicidade.

4) É indispensável distinguir, desde os tempos mais antigos, os estratos sociais da língua para cá transplantada. Por isso, estabelecemos que os portuguêses da Europa, e seus filhos, falariam um português de notável unidade, enquanto os aborígines, os negros e os mestiços se entendiam num crioulo. À proporção que se ia afirmando a civilização, o português, graças ao seu prestígio de língua dos colonizadores e da língua literária, foi-se irradiando. (Silva Neto 1950: 9-11)

Nos trechos, Silva Neto destaca a "evolução da língua" a partir de sua história, pois toma como fundamental mapear os contatos étnicos em seus movimentos e processos na descrição do PB: haveria uma "koiné", o PE falado no Brasil por portugueses e seus filhos, em que a arcaicidade e unidade da língua original seriam mantidas; por outro lado, haveria um “crioulo" falado pelos negros, índios e mestiços.

Apesar dos contatos étnicos, o Português se manteve: trata-se da "unidade na diversidade", nos termos de Silva Neto. Este último aspecto é relativo à supremacia e à uniformidade do português em relação às diferentes línguas (ou falares, como ele qualifica o crioulo) com os quais interagiu.

Nessa perspectiva, Silva Neto considera a língua como um produto social em oposição às teorias que a tinham como um organismo (August Schleicher ${ }^{46}$ e Max Müller). O português do Brasil poderia se modificar de acordo com a "vontade" dos falantes. Seria possível, em vista disso, conduzir o futuro da língua portuguesa no Brasil: “aperfeiçoá-la ou rebaixá-la”, ele afirma (Silva Neto 1950:16).

\footnotetext{
${ }^{46}$ August Schleicher (Alemanha, 1821-1868).
} 
Por outro lado, as mudanças na língua também atuariam segundo leis predeterminadas:

Ao português brasileiro podemos, portanto, atribuir características opostas: particularidades arcaicas e novos desenvolvimentos. Êstes últimos operam-se rigorosamente no sentido da deriva." (Silva Neto 1950: 208, grifos do autor).

Silva Neto se refere aqui ao conceito de 'deriva' de Sapir. Resumidamente, o conceito propõe que, independentemente da interferência externa, as mudanças em uma língua refletiriam suas tendências internas; resultariam, assim, desse desenvolvimento 'interior'. Segundo Silva Neto “[...] é preciso reconhecer que essa diferenciação [entre o PB e o PE] coincide com o estabelecimento da consciência de uma tradição comum, que encarna experiências e valores comuns" (Silva Neto 1950:115). Em outro trecho, Silva Neto afirma: "E não se pode esquecer que a ação dos aloglotas consiste, de modo geral, em precipitar a deriva da língua. A evolução opera-se no sentido de tendências preexistentes, que então irrompem, livres das peias das forças conservadoras" (p. 164, grifos do autor). Ou seja, as mudanças da língua seriam precipitações de tendências 'internas' a ela mesma, apenas favorecidas por coerções externas.

Os "novos desenvolvimentos", isto é, as mudanças na língua, advindos da "deriva" estariam, assim, relacionados aos aspectos externos (como aos contatos étnicos, no caso brasileiro, especialmente no que se refere ao contato do PB com as línguas africanas), mas dependeriam, fundamentalmente, das tendências preexistentes.

Segundo Silva Neto, os negros escravizados falariam na África um "dialeto crioulo-português":

Originários de possessões lusitanas, esses negros já falavam, certamente, um dialeto crioulo-português pois a nossa língua foi geral nas costas da África durante os séculos XV, XVI e XVII. Infelizmente ainda não se descobriu nenhum documento do linguajar que êles falavam, no Brasil, nos primeiros séculos (Silva Neto 1950: 42).

Como se nota, a queixa da inexistência de documentos que registrem as línguas faladas nos primeiros séculos é recorrente também entre os outros autores analisados até aqui: Mendonça, Raimundo e Macedo Soares ${ }^{47}$.

\footnotetext{
${ }^{47}$ A propósito da língua africana falada em Palmares, Silva Neto afirma: "É muito provável, todavia, que êles fosses bilíngües: falavam um crioulo português e um idioma africano, certamente do grupo bântico. Para assim pensar esteamo-nos em que a grande maioria dos habitantes dêsses quilombos eram angolenses. Aos Palmares chamavam êles Angola janga, isto é, Angola pequena”. (Silva Neto 1950: 101)
} 
Já no Brasil, teriam se estabelecido "línguas gerais" luso-africanas e também indígenas. Na Bahia, por exemplo, o "nagô" teria sido adotado como língua geral ${ }^{48}$. No panorama social e linguístico do Brasil Colônia que Silva Neto pretende apresentar, é esboçada a existência de três domínios: o da língua portuguesa, o do crioulo (ou semicrioulo) e o da "língua geral" 49.

Deter-nos-emos um pouco mais na sua descrição do crioulo (ou semi-crioulo). Segundo Silva Neto: “[...] crioulo ou semi-crioulo - adaptação do português no uso dos mestiços, aborígines e negros. Caracteriza-se, como em geral êsse tipo de linguajares, pela extrema simplificação das formas”. (Silva Neto 1950: 57). Em outro trecho, ele afirma:

\begin{abstract}
Aqui é necessário conceituar o que seja dialeto crioulo. Êsses falares representam uma língua européia toscamente aprendida por povos de cultura e situação inferior. Caracterizam-se por simplificação extrema, que atinge sobretudo a conjugação. São linguagens impostas pela necessidade, que têm os adultos de posição social inferior, de aprender, ràpidamente, a língua do senhor, aprendê-la de outiva ou não pelo ensino regular da escola. As gerações seguintes adquirem apenas essa linguagem de emergência, que assim consegue se firmar (Silva Neto 1950: 130, grifos do autor).
\end{abstract}

A citada deturpação e simplificação de formas do uso que negros (e também índios) teriam feito da língua portuguesa seria causada pela "[...] sua condição social ínfima e de mínima cultura" (Silva Neto 1950: 122).

Considerado como um conceito inovador para época, como afirma Lucchesi (2012), o conceito de semi-crioulo é assim definido por Silva Neto:

\begin{abstract}
Nos crioulos há vários graus de aprendizagem, pois, segundo às circunstâncias, o primitivo falar xacoco se mantém ou é aos poucos renovado pelo sangue novo da língua européia. De geração em geração, à custa sobretudo da escola, se vai aperfeiçoando e enriquecendo a primitiva fala de emergência. É o que está sucedendo com o crioulo francês da ilha Maurícia. Daí o admitir a existência de um semi-crioulo, ou seja, um estágio aperfeiçoado da primitiva aprendizagem. Êsse tipo de linguajar explicificanos o choque entre o falar europeu e o crioulo. Êsse vai sendo, pouco a pouco, penetrado de palavras e giros do falar europeu. O semi-crioulo encerra, pois, formas e torneios semi-cultos (Silva Neto 1950: 131).
\end{abstract}

\footnotetext{
${ }^{48}$ Silva Neto se baseia, entre outras obras, na A aculturação negra no Brasil (1942), de Arthur Ramos.

${ }^{49}$ Esta última "[...] falada por mamelucos e pelos brancos em suas relações com o gentio" (Silva Neto 1950: 58). Silva Neto reconhece seu desconhecimento (também) sobre essa língua.
} 
A novidade estaria em admitir níveis na formação dos crioulos. Como se vê no trecho acima, haveria um choque de culturas e língua, que ele denomina "dualidade linguística" entre a "nata social" e a "plebe" que falava um crioulo:

O grau desse falar crioulizado varia de lugar para lugar: depende da porcentagem de brancos e do status cultural. Onde menor for o número de brancos, onde a população consistir, quase exclusivamente, de índios, negros ou mestiços, maior será o grau de linguajar crioulizante. (Silva Neto 1950: 105, grifos do autor).

Desse linguajar teria se originado o dialeto caipira, segundo Silva Neto “[...] sem dúvida um dos remanescentes do primitivo crioulo" (Silva Neto 1950: 86).

O antigo crioulo - ou o tipo de linguagem que hoje o representa - ficou circunscrito aos campos do interior, no uso dos tabaréus, matutos ou caipiras, continuadores da antiga plebe rural. Deve-se reconhecer, no entanto, que essa linguagem, sobretudo nos últimos cinquenta anos, tem sofrido influências planificadoras que se irradiam das cidades e se manifestam através dos jornais, do rádio e do ensino escolar. (Silva Neto 1950: 174).

Ainda que Silva Neto considere a existência dos crioulos e concentre seu estudo sobre eles, nos termos anteriormente expostos, a relevância do contato do português com as línguas africanas (e também indígenas) no Brasil é questionada. A língua portuguesa, em sua supremacia, termo do autor, teria se sobreposto aos movimentos de contato, cuja importância é minimizada, como se vê nos trechos:

a) "Mais tarde [em relação ao indígena] entrou em cena o negro. E logo se lhe transferiram muitas responsabilidades... A verdade, porém, é que a maior parte dos fatos alegados não passava de interpretações sem base, fantasiosas ou precipitadas. Além da falta de conhecimentos de línguas americanas e africanas, a muitas das pessoas que advogavam teses indiófilas ou negrófilas faltava a indispensável base da cultura linguística e românica. De fato não basta haver semelhança entre fenômenos de linguagem brasileira e outros das falas americanas ou africanas. É preciso demonstrar que não se trata de evoluções independentes, mas que há filiação entre êles". (Silva Neto 1950: 121, grifos meus) 
b) "E por isso mesmo ela não sofreu influências decisivas, senão apenas incorporações ao vocabulário e a fraseologia bem como um ou outro fato restrito a falares regionais" (Silva Neto 1950: 128, grifos meus).

c) "No português não há, positivamente, influência de línguas africanas ou ameríndias. O que há são cicatrizes da tosca aprendizagem que da língua portuguêsa, por causa de sua mísera condição social, fizeram os negros e os índios." (Silva Neto 1950: 130, grifos meus)

d) "[Após descrição da influência do tupi na língua e na cultura brasileira, Silva Neto conclui] Mas apesar de tudo, o Brasil é português. Profundamente português, pelo idioma, pela etnografia. O mesmo se pode dizer da influência africana no Português do Brasil que está longe de ter desempenhado o papel relevante que a princípio se julgou." (Silva Neto 1950: 160, grifos meus)

Nos trechos supracitados, notamos que Silva Neto não nega o contato linguístico entre o português brasileiro e as línguas africanas, denominado por "influência", mas diminui, ao revistar obras anteriores, sua alegada importância na caracterização da língua. Silva Neto chama a atenção também para a ausência do rigor metodológico (ver item a acima) nos trabalhos que atribuíram, "exageradamente", às línguas africanas influências nas mudanças no português falado no Brasil.

Silva Neto explica por que a língua portuguesa se consolidou, ainda que tenham existido outras línguas em competição:

a) "Não seria nem natural nem razoável o esquecimento da língua portuguêsa em favor da geral [indígena]. O idioma é repositório da cultura e, por isso, está fortemente agregado ao espírito humano. Os portuguêses e seus descendentes jamais abririam mão do prestígio que lhes conferia a situação de dominadores, substituindo a língua própria" (Silva Neto 1950: 77).

b) "O grupo superior ou dominante estava associado ao uso do português e à pele clara, enquanto o grupo socialmente inferior estava ligado à pele escurecida $\mathrm{e}$ ao uso do crioulo ou do tupi... Todavia, a vitória do português não se deveu a imposição violenta da classe dominante. Ela explicou-se pelo seu prestígio 
superior, que forçava os indivíduos ao uso da língua que exprimia a melhor forma de civilização". (Silva Neto 1950: 78)

Em sua explicação de inclinação étnica e sociológica, o autor associa a língua portuguesa à pele clara, à cultura elevada, ao prestígio social e a uma "melhor forma de civilização". Esses traços garantiriam a supremacia do "espírito branco" sobre os grupos "inferiores" que buscavam adquirir a língua portuguesa como forma de integração, ou daquilo que Silva Neto chama de "ascensão social do mestiço":

a) "A ascensão social do mestiço acarretava polimento e planificação na linguagem, uma vez que essa é um importantíssimo sinal-marca de classe social. [...] Falar como branco deve ter sido a preocupação constante de todos aquêles que procuravam ascender às classes sociais mais elevadas" (Silva Neto 1950: 128)

b) “[...] A pequena élite colonial consolida-se e vai-se enriquecendo com os mestiços que, ascendendo socialmente, começam a impor-se, como fator decisivo na composição da nova sociedade. É, porém, a definitiva consolidação do espírito branco" (Silva Neto 1950: 101, grifos do autor).

Destacamos também, em relação ao tema que mais nos interessa, a proposta de Silva Neto de um estudo comparativo que levasse em conta as variedades do português faladas na África para melhor compreensão da sua proposta de formação do $\mathrm{PB}^{50}$ : "A rigorosa observação dos nossos falares rurais modernos, aliada ao estudo comparado das adaptações do português feitas na África e na Ásia, levar-nos-ia à aceitação de um estado linguístico paralelo no Brasil-Colônia. [...]” (Silva Neto 1950: 58).

\footnotetext{
${ }^{50}$ Trata-se de uma das críticas de Bonvini (2009) à produção que explorou o tema. Segundo ele, o "espaço" linguístico considerado nas produções brasileiras tinha somente o Brasil como alvo. Seria necessário tomar também como objeto de estudo as conexões entre a língua portuguesa e as línguas africanas, tanto em Portugal quanto na África.
} 


\subsubsection{2 'Incidência da análise'}

Com relação à 'incidência da análise', observamos que, em sua grande maioria, Silva Neto apresenta dados relativos à fonética-fonologia, à morfologia, à sintaxe e ao léxico, associados a dados históricos e sociais.

$\mathrm{Na}$ sua tese de que fatos constitutivos dos falares regionais teriam origem no crioulo, ele analisa os seguintes fenômenos morfológicos relativos ao sintagma nominal e à conjugação verbal:

A grande maioria dos fatos que caracterizam os nossos falares regionais tem âmbito panbrasileiro. [...] Está nesse caso o frisante fato, que representa vestígio do crioulo tradicional, do desaparecimento da flexão numérica por meio de -s: os livro, as mesa. O mesmo se dirá da extrema simplificação das formas verbais, outra cicatriz do primitivo aprendizado tosco da língua portuguêsa. De modo geral, em tôdas as regiões, só se usam a $1^{\text {a }}$ e a $3^{\text {a }}$ pessoas; o plural da $1^{\mathrm{a}}$ pessoa perde o $-s$, bamo, fazemo, fomo e, nos proparoxítonos, perde a terminação -mos: nós ía, fôsse, andava. No pret. perf. o $a$ tônico passa a $e$ : andemo, caminhemo. Em tôda a parte o futuro exprime-se com o pres. do indicativo: eu vô, nois fazemo". (Silva Neto 1950: 175-6-7, grifos do autor).

As observações acima são seguidas de uma tabela de paradigmas verbais dos falares regionais brasileiros, como no seguinte exemplo, retirado da página 178:

\section{INDICATIVO}

\section{PRESENTE}

$\begin{array}{lll}1^{\text {a }} \text { conj. } & 2^{\text {a }} \text { conj. } & 3^{\text {a }} \text { conj. } \\ \text { Eu lóvo } & \text { Eu dêvo } & \text { Eu parto } \\ \text { Tu lóva } & \text { Tu déve } & \text { Tu parte } \\ \text { Êle lóva } & \text { Êle déve } & \text { Éle parte } \\ \text { Nós lóva } & \text { Nós deve } & \text { Nós parte } \\ \text { Vós lóva } & \text { Vós deve } & \text { Vós parte } \\ \text { Êles lóva } & \text { Êles deve } & \text { Êles parte }\end{array}$

Ao que parece, Silva Neto também tenta reproduzir nessa tabela a pronunciação própria de um falar regional. Nesse domínio, ele também afirma:

Também no que se refere a grande parte dos fatos fonéticos existe unidade expressiva.

$o u=\hat{o}$ :

dotô, ôtro, pôco, lavôra, ôro, rôpa, comprô, môco, tôca,

Essa redução, comum aos dialetos de Damão, Goa, Ceilão, Macau, Cabo Verde e Guiné e representa extensão de fato já conhecido no português lusitano. (Silva Neto 1950: 183)

No trecho, ele toma o fenômeno como comum a variedades de ex-colônias de Portugal na África e na Ásia e ao próprio português lusitano: 
$e i=\hat{e}$

bêraba, isquêro, manêra, boiadêro, carrêra, bandêra, brasilêro.

lh $=i$

mio, fio, muié, atrapaiá, impuiá (=empulhar), têia, oiá, cuié.

Êsse fato é característico dos crioulos. Já foi registrado em Cabo Verde, na Guiné, em São Tomé, em Ceilão, em Dio, em Goa e na Ilha do Príncipe (Silva Neto 1950: 183).

Em outras passagens, "vestígios" de falares crioulos, como ele denomina, estariam presentes também no "linguajar urbano", mas apenas entre as classes mais modestas, como neste fenômeno da sintaxe:

Na sintaxe, do mesmo modo, ocorrem fatos comuns a nossos falares rurais e o linguajar das classes urbanas mais modestas. Entre os típicos figura o uso do ter impessoal, onde a língua culta usa o haver. Êsse fenômeno que é geral nos crioulos, representa o desenvolvimento, na bôca de pessoas incultas, de uma série de fatores convergentes. (Silva Neto 1950: 184, grifos do autor) ${ }^{51}$

O domínio lexical também está contemplado na análise de Silva Neto, em que ele reconhece a existência de vocábulos "[...] de caráter local, isto é, novas criações ou vocábulos de origem americana e africana" (Silva Neto 1950: 206)

Da mesma sorte, pouco a pouco se iam incorporando à fala dos brancos palavras vindas da África, com a importação mais e mais progressiva de negros escravos. Já pelo fim do primeiro século estavam naturalizadas moleque, amendoim, guando (...) (Silva Neto 1950: 94).

Silva Neto insiste em que alguns fenômenos já estavam presentes no português europeu:

Não havia o grupo gn. Palavras que hoje se pronunciam digno, maligno, pugnar. Depois é que, por influência erudita manifestada na grafia, se refez a grafia. [...] Nas falas regionais brasileiras são normais: dino, malino, punar (Silva Neto 1950: 192, grifos do autor)

"A palavra sereno, com o sentido de orvalho, comum na linguagem brasileira, e desconhecida à portuguesa hodierna, deve ser antiga, pois também ocorre no malaio-português" (Silva Neto 1950: 197, grifos do autor)

Outros exemplos em que mostra que o PB usa formas antigas e arcaicas do PE:

\footnotetext{
${ }^{51}$ Silva Neto recomenda aqui a leitura do artigo de Souza da Silveira publicado na Miscelânea (1938) de Said Ali.
} 
a) "[a respeito da preferência do gerúndio ao infinitivo, tal como no português arcaico] No Brasil guardamos o modo antigo.” (Silva Neto 1950: 200)

b) "A nossa linguagem familiar e regional guarda o emprego" (Silva Neto 1950:201)

c) “Muitos "brasileirismos” há, até com raízes latinas” (Silva Neto 1950:204)

Nesse sentido, na discussão sobre o uso dos pronomes pessoais como complemento verbal direto, Silva Neto discorda de Amadeu Amaral e Antenor Nascentes, autores de Dialeto Caipira e o Linguajar Carioca, respectivamente, que "[...] atribuem o dialetismo à necessidade de clareza, independente do arcaísmo." (Silva Neto 1950: 198). Ou seja, ambos acreditam que esse emprego popular dos pronomes no PB está relacionado à clareza da expressão na fala e não à origem arcaica do fenômeno no português europeu, tese defendida por Silva Neto.

Sendo assim, Silva Neto concorda com Eduardo Carlos Pereira ${ }^{52}$, autor de Gramática Histórica (1919), “[...] que vê, no fato, arcaísmo conservado e fixado para evitar anfibologia e ambiguidade". (Silva Neto 1950: 198).

Há, portanto, uma oposição entre as mudanças provocadas pelo contato e as decorrentes da evolução natural da língua: “[...] A linguagem regional brasileira: de um lado a unidade, nivelamento, provocado pela mistura dialetal; de outro as particularidades arcaizantes, devidas à ruptura da tradição, à descontinuidade que estancou a marcha evolutiva" (Silva Neto 1950: 207).

Conforme apresentamos, todos os níveis de descrição são contemplados: fonético, lexical, morfológico e sintático, frequentemente relacionados aos dados sociais e históricos.

\subsubsection{4'Fontes'}

As 'fontes' são majoritariamente obras de outros estudiosos, como relatos e testemunhos, dos quais Silva Neto retira os dados para as suas análises. O que nos chama a atenção é a imensa quantidade de material que Silva Neto reúne nessa obra que pretende descrever e analisar a história da língua.

Um dos textos selecionados pelo autor é aquele que busca representar a imitação da fala do negro ou do índio, a partir dos quais, ele propõe generalizações.

\footnotetext{
${ }^{52}$ Eduardo Carlos Pereira de Magalhães (1855 -1923), gramático mineiro.
} 
Nesse intuito, Silva Neto traz um documento de Juan Sardina Mimoso ${ }^{53}$ que descreve "a imitação do português dos índios" (Silva Neto 1950: 36) e o compara com o português falado pelos negros:

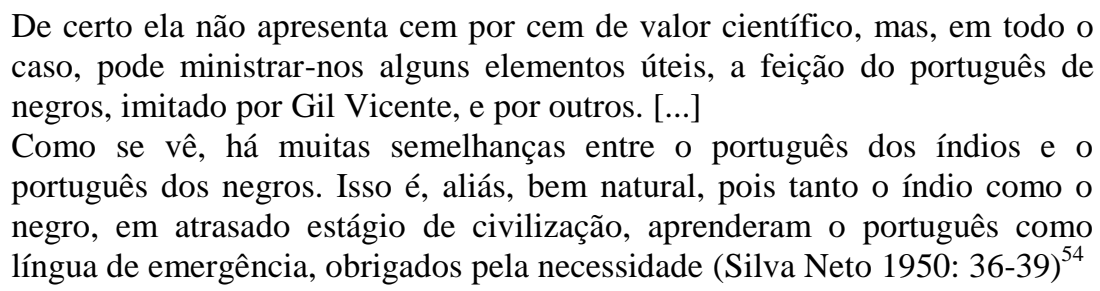

Segundo ele, com o aumento do número de negros escravizados no Brasil, surgem trabalhos em que se representa a "imitação da fala xacoca do negro" (Silva Neto 1950: 39), como por exemplo: Cancioneiro Geral (1516) compilado por Garcia de Resende ${ }^{55}$ e O Clérigo da Beira (1529) e as tragicomédias Frágua d'Amor (1524) e Nau d'Amores (1527) de Gil Vicente ${ }^{56}$. Ele recomenda ler também os trabalhos de Leite de Vasconcelos de Esquisse d'une dialectologie portugaise (1901) e de Antonio Ribeiro Chiado pelo Auto da Natural Invenção (na Revista Lusitana, 38, ed. Sabugosa, 73, J.L.V., 231), bem como os de Jacques Raimundo, O Elemento afro-negro da língua portuguesa (1933) e Negro Brasileiro e outros escritos (1936).

Silva Neto também apresenta um texto de Sílvio Romero - Cantos populares do Brasil ( $2^{\mathrm{a}}$ edição, página 183 ), que seria a imitação de fala de um negro, retirada de um reisado de Pernambuco. Ele analisa os fenômenos linguísticos mais salientes:

\footnotetext{
Nota-se que o $r$ e o $z$ finais recebem um $e$ de apoio: dare, traze, depois trage, com troca de $z \hat{e}$ em $g \hat{e}$.

Queda do $-s$ : mai. Ensurdecimento do fonema jê: rojando $>$ roxando. Troca do -l-pelo -r-: Fidélis > Fidere. Ensurdecimento do fonema vê: devagarinha $>$ difacarinha.

É curiosa a evolução de espalhar: ispaiá > sipaiá (metátese) > xipaiá. Há mudança de gênero em êsse gente, meu banda, êsse casa, êsse viola; minha boio. Observa-se ainda a forma boio < boi. (Silva Neto 1950: 43-4)
}

Silva Neto analisa também relatos e testemunhos como o de Francisco Xavier de Mendonça Furtado inserido no século XVIII (Anais da Biblioteca e Arquivo Público do Pará, 8, 1913, página 39). Segundo Francisco Furtado "dois fatos o irritaram

\footnotetext{
${ }^{53}$ Juan Sardina Mimoso e a obra Relacion de la Real Tradicomedia com que los Padres de la Compañia de Jesus... recibieron a la Magestad Católica de Felipe II, fls. 58r e 58v, 61r e 61 v, 62r e 62v, 63r.

${ }^{54}$ Jacques Raimundo analisa um texto de Gil Vicente em Elemento Negro na Língua Portuguesa (1933).

55 As edições consultadas por Silva Neto são as de 1846 (volume I) e 1852 (volume III) da editora Kausler.

${ }^{56}$ Silva Neto não informa qual foi a edição por ele consultada.
} 
sobremaneira, e o levaram a providências mais enérgicas na repressão do uso da língua da terra [...]" (Silva Neto 1950: 74). Um dos fatos: “[...] foi o ver debaixo de minha janela dois negros dos que aproximadamente se estão introduzindo da Costa da África, falando desembaraçadamente a sobredita língua e não compreendendo nada da portuguêsa" (Silva Neto 1950: 75). A partir do relato, Silva Neto concluiu:

Como se vê, até os negros recém-importados compreendiam e falavam, não o português, mas a língua geral [indígena]. Aliás, a sua condição de escravos identificava-os com as massas aborígenes, a quem estava confiado êsse papel. O govêrno metropolitano jamais se descuidara da língua portuguêsa, eficiente fator de assimilação" (Silva Neto 1950: 75)

Dados como esse, que podem ser considerados como de natureza histórica, são frequentes em sua obra e estão de acordo com o objetivo “[...] de acompanhar a progressiva ascensão social do mestiço, com as consequentes alterações no tipo de linguagem" (Silva Neto 1950: 87), em que ele procura delinear as relações entre a "língua geral”, “o crioulo de negros e índios" e "alguns episódicos idiomas africanos" "[...] sempre no sentido da preponderância daquela que representava o mais alto e perfeito meio de civilização: o português" (Silva Neto 1950: 87).

\subsubsection{4 'Técnica'}

Há em Silva Neto uma preocupação em sistematizar e oferecer uma metodologia de estudos para descrever o PB, uma vez que os estudos anteriores ou a ele contemporâneos lhe pareciam ser insuficientes no tratamento da questão dos contatos. Além da crítica ao modo de executar as pesquisas ou mesmo à ausência de método, sua proposta de estudo dialetológico exigiria pesquisas de campo para a recolha de dados:

[...] Diremos que o estudo das coisas brasileiras está a exigir numerosas e bem orientadas pesquisas de campo. Cada área deve ser estudada através do ponto de vista etnográfico: base étnica dos povoadores, classes sociais, usos e costumes, linguagem, relação com áreas vizinhas, insulamento e contato" (Silva Neto 1950: 220)

"Seria muito desejável que se intentasse um grupo de pesquisas acêrca de determinadas áreas. Assim viriam à luz interessantes monografias onde os estudos linguísticos se entrosariam com os materiais etnográficos [...]. (Silva Neto 1950: 218) 
No entanto, o trabalho que ele apresenta em Introdução ao Estudo da língua portuguesa no Brasil (1950) não parece estar baseado em pesquisas de campo como as mencionadas. No que se refere ao método de análise dos dados linguísticos, o autor concentra-se na descrição de processos de mudança, relacionando os dados linguísticos a coerções externas, como nos exemplos abaixo:

a) "A apócope do $l$ e do $r$ deve ser também fruto do tôsco aprendizado dos negros: mé, esquecê, Artu. De fato o mesmo ocorreu em Cabo Verde, São Tomé, Príncipe e Ano Bom” (Silva Neto 1950: 162, grifos do autor)

b) "Outro fenômeno curioso, pois se reflete na morfologia e na sintaxe - é a supressão do $s$ final, fato que representa uma tendência crioulizante. Êsses fatos, que se estendem por todo o Brasil, são próprios das baixas classes das capitais, ou dos tabaréus do interior" (Silva Neto 1950: 163, grifos do autor)

Neles podemos verificar uma metalinguagem comumente utilizada em trabalhos de natureza diacrônica de então, com termos como apócope, crioulizante, associada a uma tentativa de inserção do fato linguístico em uma perspectiva social, ao mencionar o estatuto social do falante, distribuição territorial do uso, etc.

\subsubsection{Síntese}

A Introdução ao Estudo da Língua Portuguesa falada no Brasil (1950) de Silva Neto é uma obra inserida no ramo dos estudos da cultura e da linguagem, em que ele procura delinear a história dos falantes da língua e da sociedade brasileira, uma "etnografia", nos termos do autor.

A 'visão de língua' é social, pois Silva Neto considera os usos e modalidades da língua e a sua evolução a partir dos contatos étnicos e interações entre os falantes. No entanto, há também em sua obra certa determinação da língua atrelada a fatores internos, o que pode ser demonstrado por sua oscilação no tratamento dos fenômenos atribuídos ao contato e às línguas africanas. De um lado, Silva Neto propõe a existência de 'semi-crioulos' e de outro diminui o peso do contato com as línguas africanas e indígenas na configuração do PB. Podemos afirmar que há uma resistência do autor em admitir a hipótese de influência determinante do contato com as línguas africanas, 
diferentemente da influência advinda do contato com as línguas indígenas, que segundo ele, está bem demonstrada por ele e por outros autores. Também é interessante notar que o autor vê dois percursos aparentemente independentes na formação do PB, um da linguagem culta (do homem branco) e outro da linguagem popular (contaminada pelo contato com línguas de povos menos evoluídos). Como a linguagem culta se imporia, por causa da superioridade da civilização à popular, o PB manteria notável unidade em relação ao PE.

Quanto à 'incidência de análise', Silva Neto expõe dados linguísticos relativos à fonética-fonologia, morfologia, sintaxe e léxico, geralmente associados a fatos históricos e sociais. Aqui, há também a correlação e análise dos fenômenos do PB em comparação com outras variedades do Português. Trata-se, portanto, de um traço também do programa de investigação 'sociocultural', que supõe a determinação dos usos linguísticos e da variação no meio social. As 'fontes' são como em todos os outros casos aqui examinados, predominantemente de segunda-mão: obras de terceiros, que por sua vez também não indicam com clareza como recolheram os dados. No entanto, é notável em Silva Neto a capacidade de reunir inúmeros materiais e sintetizá-los a partir de seus objetivos.

A "técnica" adotada concentra-se na descrição de processos de mudança, relacionando os dados linguísticos a coerções externas, logo, também correspondente ao 'programa sociocultural'.

A figura de Silva Neto difere da dos demais autores analisados, pois ele já está inserido no campo institucional de pesquisa (ainda que tal campo esteja apenas começando a se organizar em sua época). Ele é o primeiro, entre os selecionados, que tem como ocupação principal o ensino e a pesquisa linguística, feitos no âmbito universitário. Esse aspecto se reflete, por exemplo, na maior familiaridade do autor com o que se produzia na área em seu tempo, numa maior apuração da metalinguagem e num certo aumento da consciência sobre métodos (ideais) e metas para a pesquisa. Esses fatores aparecem de forma mais difusa nos demais textos analisados e certamente guardam relação com os distintos contextos de produção e divulgação do conhecimento linguístico nessas décadas que separam os quatro estudos aqui revisitados.

No próximo capítulo examinaremos quatro textos produzidos na segunda metade do século XX, período de forte institucionalização da Linguística no Brasil. 


\section{Capítulo 5}

\section{ALGUMAS TENDÊNCIAS CONTEMPORÂNEAS NOS ESTUDOS DO CONTATO DO PORTUGUÊS BRASILEIRO COM AS LÍNGUAS AFRICANAS}

Neste capítulo, percorremos, de forma panorâmica, quatro obras produzidas por pesquisadores atuais do tema do contato do PB com as línguas africanas, procurando abordá-las a partir dos mesmos parâmetros de análise utilizados no capítulo 4. Nesta apresentação de abordagens posteriores aos trabalhos de Mendonça (1933), Raimundo (1935[1933]), Macedo Soares (1942[1874-1890]) e Silva Neto (1950), procuramos destacar o possível diálogo entre textos mais contemporâneos e aqueles textos fundadores, no que diz respeito às questões metodológicas e às 'fontes'. Não se trata aqui de pressupor continuidade histórica ou 'influência' entre obras ou entre autores ${ }^{1}$, mas, ao contrário, verificar como se costuram, se mantém ou se esvaem certos traços caracterizadores dos textos iniciais da 'tradição' na produção atual. A partir dessa reflexão, identificamos algumas tendências ou caminhos atuais dos estudos do contato do PB com as línguas africanas em território nacional.

Como já dissemos no capítulo 2, a análise não tem, pela própria quantidade de textos selecionados, qualquer pretensão de exaustividade. Acreditamos, contudo, após o levantamento geral de fontes que realizamos, que os textos selecionados sejam bastante representativos na área de investigação.

\subsection{Contextualização geral}

Muitas das características do contexto dessa produção acadêmica parecem diferenciá-lo do contexto em que foram escritas as obras de Mendonça (1933), Raimundo (1935[1933]), Macedo Soares (1942[1874-1890]) e Silva Neto (1950) do

\footnotetext{
${ }^{1}$ Nesse sentido, é possível que os autores contemporâneos não tenham lido as obras inaugurais, por nós selecionadas, ou mesmo não se reconheçam como participantes da tradição de pesquisa que mapeamos. De todo modo, a história os pôs em sequência no desenvolvimento desta linha de pesquisa.
} 
final do século XIX e na primeira metade do século XX. A começar pelo fato de que são obras de pesquisadores que ocupam postos em universidades, condição profissional que, entre os estudiosos anteriores, só foi partilhada com Silva Neto.

Trata-se, ademais, de pesquisadores amadurecidos e prestigiados como especialistas no tema que perseguem há algumas décadas. Alguns deles estão no topo da carreira acadêmica, na posição de professor livre-docente ou professor-titular e têm bastante circulação no contexto acadêmico brasileiro e internacional, fator demonstrado, por exemplo, pelas parcerias com pesquisadores estrangeiros em projetos e publicações. São considerados como pesquisadores-referência na área e sua produção tem impacto na comunidade acadêmica que se dedica ao tema.

O modo de circulação dos materiais também é diverso, na medida em que se ancoram em atividades e contextos tornados, apenas com o tempo, comuns no cotidiano acadêmico universitário brasileiro: são conferências que resultaram em artigos, teses de livre-docência, livros de grupos e projetos de pesquisa, etc.

As 'redes' de colaboração mais natural e explicitamente estabelecidas e a disponibilidade de um legado de 'novos' conhecimentos construídos pela Linguística geral e por subáreas próximas são também elementos importantes desse novo contexto de produção.

Na mesma medida, a operacionalização do trabalho intelectual na universidade, tal como avaliada por Chauí $2014^{2}$, parece ter algum impacto sobre esse atual contexto de produção e divulgação do conhecimento:

[...] a universidade operacional está estruturada por estratégias e programas de eficácia organizacional e, portanto, pela particularidade e instabilidade dos meios e dos objetivos. Definida e estruturada por normas e padrões inteiramente alheios ao conhecimento e à formação intelectual, está pulverizada em micro-organizações que ocupam seus docentes e curvam seus estudantes a exigências exteriores ao trabalho intelectual. A heteronímia da universidade autônoma é visível a olho nu: o aumento insano de horas-aula, a diminuição do tempo para mestrado e doutorado, a avaliação pela quantidade de publicações, colóquios, congressos, a multiplicação de comissões e relatórios etc. [...]. (Chauí 2014:5)

Nas diferentes áreas e linhas de pesquisa que se desenvolvem no país, a fragmentação e a subespecialização se firmam:

\footnotetext{
2 Manuscrito correspondente a Aula Magna proferida, disponível, também em vídeo, em http://www.adusp.org.br/index.php/campanha-salarial-2014cs/2076-aula-magna-de-marilena-chauidesvenda-universidade-operacional
} 


\begin{abstract}
[...] no jogo estratégico da competição no mercado, a organização [universitária] se mantém e se afirma se for capaz de propor áreas de problemas, dificuldades, obstáculos sempre novos, o que é feito pela fragmentação de antigos problemas em novíssimos microproblemas, sobre os quais o controle parece ser cada vez maior. A fragmentação, condição de sobrevivência da organização, torna-se real e propõe a especialização como estratégia principal e entende por "pesquisa" a delimitação estratégica de um campo de intervenção e controle. É evidente que a avaliação desse trabalho só pode ser feita em termos compreensíveis para uma organização, isto é, [...] pautada pela ideia de produtividade, que avalia em quanto tempo, com que custo e quanto foi produzido. (Chaú 2014: 7)
\end{abstract}

As obras que analisamos recobrem o período de 2007 a 2009, mas são resultado de longos percursos acadêmicos desenvolvidos em centros de pesquisa consolidados no Brasil ao longo do século XX. Na vasta produção de seus autores, os textos selecionados sinalizam movimentos de síntese e de reconstrução desses ricos percursos.

\title{
5.2. Origens Do Português Brasileiro (2007), de Anthony Julius Naro e Maria Marta Pereira Scherre
}

\subsubsection{Breve perfil biográfico dos agentes e visão geral da obra}

Anthony Julius Naro é norte-americano, formou-se em Matemática pela Polytechnic University of New York (1963), doutorou-se em Linguística com a tese "History of Portuguese Passives and Impersonals" na Massachusetts Institute of Technology (1968) (EUA), sob a orientação de Paul Kiparsky, e fez Pós-Doutorado na University of Chicago (EUA). Desde 1988 é professor titular da Universidade Federal do Rio de Janeiro (UFRJ).

Ao longo de sua carreira, ele foi professor-visitante nas seguintes universidades: University of Chicago (EUA) (2001), University of Pennsylvania (EUA) (1992-93), Universitá Di Roma La Sapienza (Itália) (1990), Universidade Federal de Sergipe (1987-88), University of California at Los Angeles (EUA) (1982-83) ${ }^{3}$, Cornell University Summer Linguistic Institute (EUA) (1981), Universidade de Brasília (1978, 1981, 1983), Pontifícia Universidade Católica do Rio Grande do Sul (1976-77), University Of Illinois Chicago (EUA) (1968-69) e Boston University (EUA) (1965-66). Além disso, fez estágios de pesquisa em Coimbra, Lisboa (Portugal), Luanda e Malanje (Angola).

\footnotetext{
${ }^{3}$ Ano em que também foi professor visitante na Linguistic Society Of America (EUA) (1983).
} 
Sua produção científica se concentra nas subáreas de Sociolinguística e Linguística Histórica e trata, principalmente, dos temas: concordância verbal, ordem verbo-sujeito, pidginização e crioulização, variação linguística ${ }^{4}$.

Em seu lattes, constam as seguintes obras publicadas ou organizadas: Origens do Português Brasileiro (2007) com Marta Scherre; Competências básicas do Português (1977) com Miriam Lemle; organização de Tendências atuais da linguística e da filologia no Brasil (1976) e Estudos diacrônicos (1973).

Maria Marta Pereira Scherre é Licenciada em Letras pela PUC (Pontifícia Universidade Católica) de Minas Gerais (1973), tem mestrado em Letras pela PUC no Rio de Janeiro (1978), com a dissertação “A Regra de Concordância de Número no Sintagma Nominal em Português" (bolsa CAPES), e doutorado em linguística pela UFRJ (Universidade Federal do Rio de Janeiro), em 1988, com a tese: "Reanálise da Concordância Nominal em Português". Seu mestrado e doutorado foram orientados por Anthony Julius Naro.

É membro do Programa de Estudos sobre o Uso da Língua (PEUL) ${ }^{5}$ da UFRJ e do Grupo de Estudos Avançados em Sociolinguística (GEAS) da UnB”.

A pesquisadora destaca entre as suas publicações, além da obra por nós analisada, o livro: Doa-se lindos filhotes de poodle - variação linguística, mídia e preconceito (2005). No contexto internacional, também destaca que participou, em 2006, das edições de Encyclopedia of Language \& Linguistics (Oxford: Elsevier) e de Sociolinguistic/Soziolinguistik - An International Handbook of the Science of Language and Society (Berlin/New York: Walter de Gruyter), respectivamente com o verbete "Speech Community" e com o texto "Brazil/Brasilien".

Marta Scherre se reconhece como atuante das seguintes subáreas: Sociolinguística e Dialetologia, Teoria e análise linguística e Língua Portuguesa. Ao observamos sua produção intelectual, verificamos que ela se concentra, principalmente,

\footnotetext{
${ }^{4}$ Informações retiradas do currículo lattes do pesquisador: http://lattes.cnpq.br/4161994799982051, visualizado, pela última vez, em 24/07/2014. Levamos em conta o resumo produzido por ele e também uma observação panorâmica dos dados, com vistas a confirmar a auto percepção do pesquisador. $\mathrm{O}$ mesmo procedimento foi adotado com os demais linguistas selecionados.

${ }^{5}$ São participantes desse grupo: Anthony J. Naro, Claudia Roncarati, Christina Abreu, Helena Gryner, Maria Cecilia Mollica, Maria da Conceição Paiva, Maria Eugênia Lamoglia Duarte, Maria Luíza Braga e Vera Lúcia Paredes.
} 
nos fenômenos de concordância nominal e verbal, imperativo, variação e mudança linguística. ${ }^{6}$

Como vimos, Naro foi orientador de Scherre em sua dissertação de mestrado (1974-1978) e tese de doutorado (1979-1988). Ambos têm uma longa e profícua parceria acadêmica desde, pelo menos, 1974, quando atuaram juntos no Projeto Censo da Variação Linguística no Estado do Rio de Janeiro (1980-1982). Antes de iniciarem estudos conjuntos sobre a hipótese do contato, Scherre já se dedicava ao fenômeno de concordância nominal e verbal e Naro já estava inserido no debate sobre o português brasileiro, bem como naquele sobre o contato e os pidgins e línguas crioulas de maneira geral.

O livro Origens do português brasileiro é uma reunião de sete artigos publicados entre os anos de 1993 a 2003 pelos pesquisadores Anthony Naro e Marta Scherre, reescritos (em maior ou menor grau). Esses artigos têm o seguinte objetivo:

[...] apresentar evidências de que características morfossintáticas e fonológicas do português brasileiro, atualmente envoltas em estigma e preconceito social, são heranças românicas e portuguesas arcaicas e clássicas, e não modificações mais recentes advindas das línguas africanas, que vieram para o Brasil com seus povos escravizados e subjugados, ou das línguas dos povos ameríndios, que aqui já se encontravam quando vieram os colonizadores europeus. Tampouco são resultado de processos de simplificação ou outras modificações espontâneas causadas pelo contato, durante o processo de transmissão não-tradicional da língua. (Naro \& Scherre 2007:17)

Ao defender essa hipótese de maneira bastante clara, eles se opõem a outras hipóteses sobre a formação do PB: "Nossa posição é diferente da hipótese da crioulização ou de semi-crioulização da língua portuguesa em terras brasileiras, assumida por diversos estudiosos, entre os quais se incluem alguns pesquisadores estrangeiros" (Naro \& Scherre 2007:17). Em outro trecho, eles se defendem da crítica que os acusa de negar a 'influência':

Assim, longe de negar a importância da influência africana e indígena para nossa cultura, queremos identificar as raízes linguísticas românicas e lusitanas que insistem em permanecer em nossas bocas e em nossas falas e que, com mais intensidade, se revelam nas falas e nas bocas dos brasileiros que tiveram pouco acesso aos bancos escolares ou que habitam as áreas rurais e as periferias das grandes cidades. (Naro \& Scherre 2007:17)

\footnotetext{
${ }^{6}$ Informações retiradas do currículo lattes da pesquisadora: http://lattes.cnpq.br/6129587291049735, atualizado em 04/05/2014 e visualizado, pela última vez, em 01/07/2014, seguindo os mesmos procedimentos mencionados na nota da página anterior.
} 
O capítulo que selecionamos como exemplo da produção dos autores, "Sobre as origens do português popular do Brasil" (p. 25-48), em que Naro \& Scherre fazem “[...] algumas reflexões a respeito da origem do português popular do Brasil, apresentando evidências históricas, linguísticas e sociais" (Naro \& Scherre 2007: 25), é:

[...] uma versão ampliada e atualizada de um texto que foi escrito para homenagear nosso saudoso colega Fernando Tarallo, publicado em 1993, na revista de Documentação de Estudos em Linguística Teórica e Aplicada (D.E.L.T.A.). Nele conjugam-se o rastreamento de traços linguísticos contidos nos livros de história das línguas românicas e resultados de pesquisas linguísticas sobre a variação da concordância nominal de número, um dos aspectos assumido como dos mais característicos da pressuposta crioulização da língua portuguesa em terras brasileiras, nos termos de Adolfo Coelho, escritas na segunda metade do século XIX (1967: 43). (Naro \& Scherre 2007: 18)

Ainda que os demais capítulos apresentem um maior volume de dados, como afirma a própria autora -“o coração do nosso garimpo" -, selecionamos o capítulo citado por ter tido mais impacto nos estudos do contato (aferível pelo seu número de citações). Trata-se de uma réplica/homenagem ao artigo "On the Alleged Creole Origin of Brazilian Portuguese: Untarget Syntatic Changes”, de Fernando Tarallo ${ }^{7}$, apresentado no Congresso "Créole Located in Time an Space" (LSA Institute, CUNY, New York, 1986) e publicado em 1993. Ambos os textos têm destaque na retrospectiva histórica de Bonvini (2009), sendo considerados como a 'contestação', termo de Bonvini, das hipóteses da influência das línguas africanas no PB e também da crioulização do PB.

Outro argumento a favor de nossa escolha: todos os capítulos do livro sustentam a mesma tese, embora o tom assertivo das proposições vá se intensificando no correr das páginas. O livro se organiza do seguinte modo:

\begin{tabular}{|l|}
\hline Agradecimentos (p. 9) \\
\hline Prefácio - Ataliba T. de Castilho (USP, CNPq) (p. 11-15) \\
\hline Introdução - Maria Marta Pereira Scherre (p. 17-23) \\
\hline Capítulo 1: Sobre as origens do português popular do Brasil (p. 25-48) \\
\hline Capítulo 2: Concordância variável em português: a situação no Brasil e em \\
Portugal (p. 49-69) \\
\hline Capítulo 3: Garimpando as origens do português brasileiro: sobre três \\
\hline
\end{tabular}

\footnotetext{
7 Fernando Tarallo [1951-1992] foi doutor em Sociolinguística pela Universidade da Pensilvânia e professor da Universidade Estadual de Campinas e da Pontifícia Universidade Católica de São Paulo.
} 


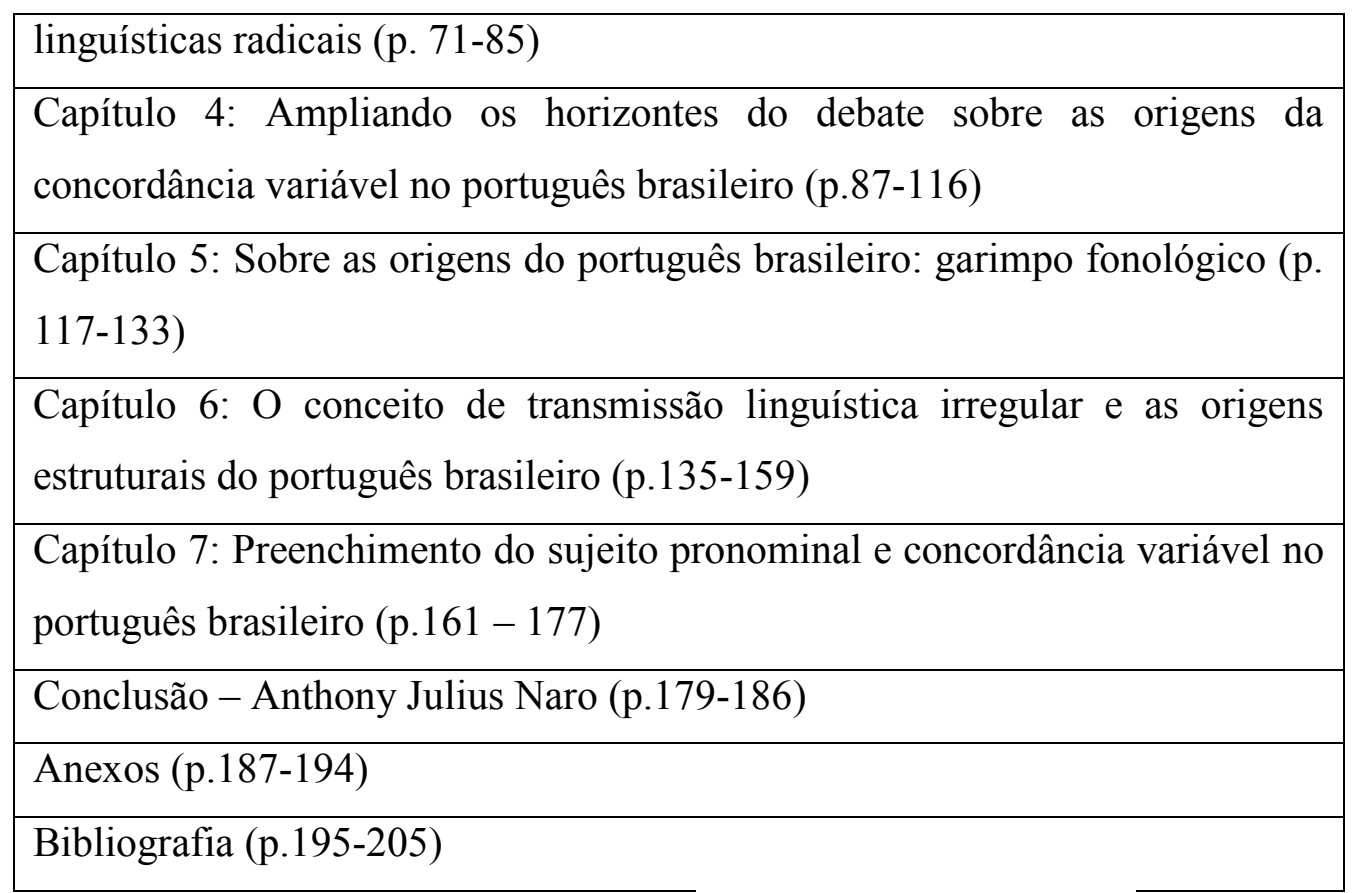

Quadro 5.1: Estrutura da obra Origens do português brasileiro

O prefácio escrito por Ataliba T. de Castilho ${ }^{8}$ destaca:

Este livro está nucleado à volta dos seguintes eixos, da maior importância para o debate atual sobre o português brasileiro: uma identificação rigorosa de fenômenos variáveis do português brasileiro em dados do português europeu popular, uma interpretação do português brasileiro mais conforme à sua sócio-história, e uma reflexão teórica inovadora sobre aquisição e mudança (Naro \& Scherre 2007: 11)

Ataliba de Castilho atribui as seguintes qualidades ao trabalho de Naro \& Scherre: "cuidadoso apanhado de trabalhos dos autores", "rigorosa descrição do português brasileiro", “interpretação valiosa”, "leitura apaixonante”. Lembra também da

\footnotetext{
8 "Licenciado em Letras Clássicas em 1959, Especialização em 1960, doutor em Linguística em 1966, livre-docente em Filologia e Linguística Portuguesa em 1993, professor titular em 1996 pela Universidade de São Paulo, Professor Emérito da USP desde 2013. Ex-professor titular da Universidade Estadual Paulista, campus de Marília (1961-1975), então CESESP. Professor titular aposentado da Universidade Estadual de Campinas (1975-1991) e da Universidade de São Paulo (1996-2006). Atualmente é professor senior na Universidade de São Paulo e professor colaborador voluntário na Universidade Estadual de Campinas. Coordenou os seguintes projetos coletivos de pesquisa: Projeto NURC/SP (1970-1988), Projeto de Gramática do Português Falado (1988-2011), Projeto para a História do Português Brasileiro, equipe de São Paulo, de 1995 a 2011, quando foi substituído a seu pedido. Editor geral da obra coletiva História do Português Brasileiro, 5 volumes, em andamento. Membro do corpo editorial das seguintes revistas: Alfa (Revista de Linguística da UNESP), Linguística (revista da Associação de Linguística e Filologia da América Latina), Revista do GEL, Cadernos de Estudos Linguísticos (Unicamp), Filologia e Linguística Portuguesa (USP). Tem desenvolvido pesquisas na área de Linguística do Português, com ênfase nas seguintes áreas: descrição da língua falada, sintaxe funcionalista do português brasileiro, história do português brasileiro, análise multissistêmica do português brasileiro. É assessor linguístico do Museu da Língua Portuguesa desde 2006". (Texto retirado do currículo lattes do autor. Disponível em http://lattes.cnpq.br/8995142541264871. Visualizado em $14 / 07 / 2014)$
} 
continuidade dos trabalhos de mais de 50 anos e de como o projeto de "Censo Linguístico" deu surgimento a outros projetos de mesma natureza.

\title{
5.2.2 'Horizonte de retrospecção'
}

Naro \& Scherre assumem o conceito de 'deriva' proposto por Edward Sapir (1949/1921:145-170). Resumidamente, tal conceito propõe que a língua tem um desenvolvimento que lhe é inerente, isto é, as mudanças da língua são, na verdade, resultantes de tendências internamente prefiguradas.

No âmbito nacional, eles rechaçam a posição de Silva Neto (1986[1950]), que defendeu a existência de um 'semicrioulo' e também a de alguns de seus colegas contemporâneos, que apontam no PB um passado crioulo:

[...] rejeitamos explicitamente a posição de que o português popular do Brasil é um semicrioulo, tem uma história crioula, ou tem a ele subjacente uma leve crioulização (Silva Neto, 1986; Câmara Jr., 1975, Jeroslow, 1975; Guy, 1989; Holm, 1992; Baxter \& Lucchesi, 1993; Ferreira, 1994) (Naro \& Scherre 2007: 67)

As críticas aos defensores dessa posição recaem principalmente na figura de Dante Lucchesi ${ }^{9}$ :

\begin{abstract}
Nosso colega brasileiro Dante Lucchesi já disse publicamente, mais de uma vez, que estamos olhando para dados excêntricos; diferentemente, dizemos e avaliamos que estamos de posse de registros ímpares da fala real e usual do povo português, que revelam fatos passados e trazem luzes a respeito de formas e estruturas que certamente existiam há 50 anos em terras portuguesas e devem lá ter existido há 500 anos, alcançando terras brasileiras, com a chegada de portugueses de todas as regiões de Portugal e de classes sociais diversificadas, muitos deles sem nenhuma escolarização formal (Naro \& Scherre 2007: 21)
\end{abstract}

Naro e Scherre, portanto, não atribuem papel algum a um "suposto crioulo de base lexical portuguesa, entendido como uma língua falada pela comunidade negra e estruturalmente diferente da de outras etnias" (Naro \& Scherre 2007: 25-6). Não emitem nenhuma avaliação sobre a influência lexical africana no PB, para isso, recomendam a leitura do texto de Castro (2005).

\footnotetext{
${ }^{9}$ Como veremos mais adiante no perfil biográfico de Dante Lucchesi, sua tese de Doutorado: A variação na concordância de gênero em uma comunidade de fala afro-brasileira: novos elementos sobre a formação do português popular do Brasil (1996-2000), na UFRJ, também foi realizada sob orientação de Anthony Naro.
} 
Especificamente sobre o fenômeno da concordância nominal no PB, um dos temas em análise, eles consideram: sobre o dialeto caipira, Amaral (1920); sobre o português popular do Nordeste, Monteiro (1933) e Marroquim (1945); sobre o linguajar carioca, Nascentes (1953) e, sobre o português de forma geral, Melo (1946).

\title{
5.2.3 'Programa de investigação'
}

\subsubsection{1 'Visão de língua'}

O ponto de vista adotado pelos autores, de que o contato linguístico acelerou tendências previstas no português europeu, faz com que a visão de língua seja tanto descritivista quanto sociocultural. No trecho abaixo, por exemplo, na retrospectiva dos trabalhos que abordaram a concordância nominal, afirmam:

\begin{abstract}
[...] pode-se inferir que as variáveis sociais mais importantes para o entendimento das diferenças do comportamento da concordância nominal são o grau de escolarização e/ou contraste rural-urbano, e não a procedência geográfica por cidade, estado e região. Se a origem do português do Brasil se devesse a existência de um pidgin ou de um crioulo de base lexical portuguesa e gramática africana, seria de se esperar que as áreas geográficas que apresentavam maior concentração de escravos em meados do século XIX evidenciassem diferença de comportamento no que toca à concordância nominal e verbal, fato não constatado pelos diversos trabalhos existentes (Naro \& Scherre 2007: 46)
\end{abstract}

Naro \& Scherre se reconhecem como sociolinguistas e levam em consideração, na análise do fenômeno em questão variáveis sociais, no caso: grau de escolarização e o contraste rural-urbano.

No entanto, eles privilegiam os aspectos internos da língua portuguesa, tida como um sistema autônomo. Destacamos o trecho abaixo, ainda que extenso, que revela a visão geral de língua sustentada pelos autores:

[...] Temos que levar em conta a dimensão tempo, ao longo da qual chegaram ao Brasil ondas de populações de diversas origens étnicas. Esses movimentos demográficos tiveram o efeito de reforçar certas forças arroladas acima e de inibir outras. Naturalmente o efeito não foi uniforme nas diversas comunidades linguísticas e nem mesmo nos indivíduos, mas em termos gerais costuma-se distinguir três fases de predomínio étnico-demográfico: a fase inicial de predomínio ameríndio, a fase de predomínio africano e por último uma fase importante de reforço europeu e começo da imigração asiática. Entretanto, a última fase não chegou a esmagar a fase anterior africana com a mesma força que esta teve sobre a fase ameríndia. As primeiras duas fases eram pidginizantes e caracterizadas pelo aprendizado do português como segunda língua; a última é mais padronizante, embora 
também marcada pelo aprendizado do português como segunda língua por populações europeia e asiáticas, oriundas de terras onde o português era desconhecido. Através de todas essas fases, segundo nossa visão, o impulso motor de desenvolvimento do português do Brasil veio embutido na deriva secular da língua de Portugal. Se as sementes trazidas de lá germinaram mais rápido e cresceram mais fortes, é que as condições, aqui, mostraram-se mais propícias devido a uma CONFLUÊNCIA DE MOTIVOS. (Naro \& Scherre 2007: 48, destaque dos autores)

De outra maneira, fatores externos atuam em segundo plano na análise de Naro \& Scherre. Eles consideram que os contatos inter-étnicos aceleraram tendências relativas ao sistema interno da língua.

\subsubsection{2 'Incidência da análise'}

As análises de Naro \& Scherre incidem, principalmente, sobre os fenômenos de concordância verbal e nominal, inseridos no domínio da morfossintaxe, cuja variação é geralmente atribuída, por outros autores, ao contato do português com as línguas africanas. Especialmente sobre a concordância nominal, os autores exemplificam do seguinte modo, a partir das variáveis: (1) posição linear, (2) classe nuclear e não-nuclear e (3) relação entre classe nuclear e não-nuclear, como segue:

1) classe não-nuclear anteposta na primeira posição (constituída pelos adjetivos, possessivos, quantificadores, artigos, demonstrativos, identificadores e indefinidos que ocorrem na primeira posição do $\mathrm{SN}$ ):

$$
\begin{aligned}
& \text { novas escolas/suas tias/todos eles } \\
& \text { as boas ações/aquelas cruzinha toda } \\
& \text { determinadas pessoas/alguns meses }
\end{aligned}
$$

2) Classe não-nuclear anteposta na segunda posição (constituída pelos adjetivos, possessivos, quantificadores, artigos, demonstrativos, identificadores e indefinidos antepostos na segunda posição do $\mathrm{SN}$ ):

todos os anos/todos esses homens

os próprios vagabundos/tantas outras famílias

os meus ainda mais velhos amigos/as boas ações

(Naro \& Scherre 2007: 39, grifos dos autores)

Em outro trecho, os autores mobilizam dados do francês, como apresentamos a seguir. No trecho, Naro \& Scherre discutem a primeira posição do SN: 
1) por um artigo: le livre [1Ә livrӘ] 'o livro' / les livres [1Ә livrӘ] 'os livro';

2) por um possessivo: mon livre [mõ livrӘ] 'meu livro' / mes livres [me livrЭ] 'meus livro'; mon ami [mõnami] 'meu amigo' / mes amis [mezami] 'meus amigo'];

(Naro \& Scherre, 2007: 35, grifos dos autores)

A respeito do tema, os pesquisadores afirmam:

Temos a impressão de que a concordância variável pode ser encontrada em todo o território de Portugal, tanto entre o verbo e o sujeito quanto dentro do sintagma nominal. Não são claras as razões para a falta de referências a esse fenômeno na literatura e para as intuições de nossos colegas portugueses negarem a sua existência. As formas sem concordância são estatisticamente raras, mas não encontramos dificuldade em localizar um número razoável delas em apenas alguns dias de audição de fitas gravadas (na companhia de alguns pesquisadores que antes negavam a sua existência). É claro que muito trabalho está sendo feito a fim de se determinar as dimensões geográficas e estruturais da variação atualmente em Portugal, mas sua existência não pode mais ser negada. A variação na concordância não é um fenômeno exclusivamente brasileiro na gramática sincrônica do português moderno (Naro \& Scherre 2007: 57-8)

Eles destacam a existência do fenômeno também no PE, contrariando o posicionamento de pesquisadores portugueses e também de brasileiros que asseguram a idiossincrasia do traço no PB, associando-o ao contato com línguas africanas. Naro \& Scherre se posicionam quanto às formas linguísticas privilegiadas nos estudos do contato - o léxico e a fonética-fonologia:

\begin{abstract}
Não queremos minimizar nossas influências africanas. Disso, muito nos orgulhamos. Somos todos uma síntese da ampla e profunda miscigenação que ocorreu em terras brasileiras. Certamente essa miscigenação ocorreu também no plano linguístico, inegavelmente no plano lexical de forma ampla. Sugerimos apenas que se observem os fatos, ou seja, no que diz respeito às origens estruturais do português brasileiro, é fundamental que se atribua o verdadeiro papel a quem de direito. Exceto a palatalização de $-\mathrm{t}$, - $\mathrm{d}$ diante de $-i$, sem qualquer registro para o português europeu, mas existente no quimbundo e também em muitas outras línguas africanas ou não, os traços linguísticos que têm sido atribuídos às línguas africanas são predominantemente das falas menos prestigiadas (Naro \& Scherre 2007: 130)
\end{abstract}

\title{
5.2.3.3 'Fontes'
}

Com relação às fontes materiais selecionadas, Naro \& Scherre retiram dados:

(1) "garimpados", na terminologia dos autores, do PE de obras de dialetologia portuguesa; 
(2) dos textos de Silva Neto (1950) e Aryon Rodrigues ${ }^{10}$ (1986) para conhecimento do uso da "língua geral" e sobre a existência de um pidgin ou crioulo em território nacional;

(3) de Leite de Vasconcelos (1987/1901), para dados do PE no século XIX;

(4) Blanche-Benveniste ${ }^{11}$ (1999), para dados do francês antigo e atual, esse também com a contribuição de Rachel Dettoni, Conceição Paiva e Josane Moreira de Oliveira $^{12}$ (Naro \& Scherre 2007: 35);

(5) da tese de Scherre (1988) sobre o português atual falado, baseada no "banco de dados do Programa de Estudos do Uso da Língua (PEUL), programa de pesquisa desenvolvido desde 1982 por uma equipe de pesquisadores da UFRJ, UFRRJ/CNPq e UFF, através do Departamento de Linguística e Filologia da Faculdade de Letras da UFRJ" (p. 37-8, nota) e

(6) de Guy $^{13}$ (1989), para dados de línguas crioulas e pidgins.

A confrontação dos dados centra-se, especialmente, sobre o PE e o PB. Segundo a hipótese adotada pelos pesquisadores, denominada "uniformitarista", de William Labov $^{14}$ : "a variação de hoje foi a variação de ontem". Assim, para os pesquisadores, "A evidência de que realmente dispomos se resume aos dados relativos ao estado atual da língua portuguesa no Brasil, que pode ser comparado com o estágio atestado nos documentos existentes da época anterior à colonização" (Naro \& Scherre 2007: 145).

Naro \& Scherre, como os demais autores que analisamos, reclamam da ausência de dados históricos relativos ao contato do PB com línguas africanas:

O fato é que não temos como responder com segurança a todas estas perguntas por uma razão instransponível: trata-se de épocas pretéritas, para as quais não existe documentação história adequada. Contudo, parece bastante improvável que tenha existido uma situação de pidgin de base lexical portuguesa estável no Brasil, porque na época mais crítica para o suposto processo de crioulização - séculos XVI e XVII -, já existia a língua geral de base lexical tupi, que era capaz de preencher as necessidades comunicativas mais prementes de forma satisfatória. $\mathrm{O}$ uso da língua geral é largamente atestado na documentação história relativa ao Brasil, que sequer menciona

\footnotetext{
10 Aryon Dall'Igna Rodrigues (Curitiba, 1925 - Brasília, 2014), linguista especialista nos estudos de línguas indígenas brasileiras.

${ }^{11}$ Claire Blanche-Benveniste (França, 1935-2010), linguista e filóloga especialista na sintaxe do francês falado e na intercompreensão entre línguas românicas.

${ }^{12}$ Raquel do Valle Dettoni, Prof ${ }^{\mathrm{a}}$. Dr ${ }^{\mathrm{a}}$ da UnB; Maria da Conceição Auxiliadora de Paiva, $\operatorname{Prof}^{\mathrm{a}} \operatorname{Dr}^{\mathrm{a}}$ da UFRJ e Josane Moreira de Oliveira, $\operatorname{Prof}^{a} \operatorname{Dr}^{\mathrm{a}}$ da UEFS - todas inseridas na área de variação e mudança linguística.

${ }^{13}$ Gregory Riordan Guy (EUA), Prof ${ }^{\mathrm{o}}$ titular da University New York, sociolinguista.

14 William Labov, linguista norteamericano, Prof ${ }^{\circ}$ da University of Pennsylvania, fundador da sociolinguística variacionista.
} 
qualquer versão simplificada do português em uso para fins de comunicação (Naro \& Scherre 2007: 144)

A respeito dos dados da documentação mais recentes sobre o $\mathrm{PB}$, Naro \& Scherre reafirmam a inexistência de dados que comprovem um crioulo brasileiro:

Para a história da língua portuguesa no Brasil, existe uma documentação razoavelmente rica e variada que vai desde relatos de viajantes, missionários e autoridades governamentais, a partir do século XVI, a representações de fala de alguns grupos populacionais em peças, jornais etc., a partir, principalmente, do século XIX [...] Apesar da riqueza das fontes disponíveis a respeito da fala dos índios e dos brancos, é escassa qualquer evidência documentária específica quanto ao português ou outras línguas faladas pelos africanos no Brasil, além de algumas menções breves de africanos que não dominavam o português, mas apenas a língua geral tupi ou línguas africanas. A documentação não transmite nem a mais leve suspeita de que a língua portuguesa falada pelos brasileiros descendentes dos primeiros cativos africanos fosse diferente da fala de brasileiros de outras origens étnicas (mantidas, naturalmente, as semelhanças socioeconômicas relevantes). (Naro \& Scherre: 28)

\subsubsection{4 'Técnica'}

Naro e Scherre buscam em etapas anteriores do português europeu as explicações para fenômenos atribuídos ao contato, como a redução morfológica da concordância nominal e verbal. Segundo eles, há evidência de que a redução fonológica gerou a redução morfológica da concordância:

\footnotetext{
De fato, essa primeira etapa - a desnasalização - existe na fala popular de Portugal, principalmente na região de Entre-Douro-e-Minho, onde, segundo Leite de Vasconcellos (1987/1901: 87), a regra atua tanto em nomes (virgem como birde) como em verbos (vertem como bérte). Temos aí uma origem europeia da redução da concordância verbal, sem qualquer influência exterior necessária, africana ou ameríndia (Naro \& Scherre 2007: 33)
}

Eles recorrem também à língua latina, tendo em vista que os fenômenos em análise não são restritos ao PB: “Admitindo que a mudança linguística que envolve a concordância verbo/sujeito tenha se iniciado na fonologia, principalmente através da desnasalização, concluímos que suas origens remontam pelo menos até os tempos préclássicos" (Naro \& Scherre 2007: 33).

Para tanto, utilizam o programa computacional Varbrul (1988) para análise quantitativa dos dados codificados, cuja apresentação reproduzimos parcialmente a seguir (Naro \& Scherre 2007: 43, grifos dos autores). 


\begin{tabular}{|c|c|c|c|c|c|}
\hline $\begin{array}{c}\text { FALANTES } \\
\text { FATORES }\end{array}$ & & $\begin{array}{c}\text { TODOS OS } \\
\text { FALANTES }\end{array}$ & $\begin{array}{c}\text { Falantes de } 1 \text { a } 4 \\
\text { anos de } \\
\text { escolarização }\end{array}$ & $\begin{array}{c}\text { Falantes de } 5 \text { a } 8 \\
\text { anos de } \\
\text { escolarização }\end{array}$ & $\begin{array}{c}\text { Falantes de } 9 \text { a } \\
11 \text { anos de } \\
\text { escolarização }\end{array}$ \\
\hline $\begin{array}{l}\text { Elemento } \\
\text { nominal À } \\
\text { ESQUERDA } \\
\text { do núcleo na } \\
\text { posição } 1\end{array}$ & $\begin{array}{l}\text { Freq. } \\
\text { Peso } \\
\text { relativo }\end{array}$ & $4.8885 / 5.0005=98 \%$ & $1.820 / 1.869=97 \%$ & $1.780 / 1.824=98 \%$ & $1.285 / 1.312=98 \%$ \\
\hline $\begin{array}{l}\text { Elemento } \\
\text { nominal À } \\
\text { ESQUERDA } \\
\text { do núcleo na } \\
\text { posição } 2\end{array}$ & $\begin{array}{l}\text { Freq. } \\
\text { Peso } \\
\text { relativo }\end{array}$ & $\begin{array}{c}264 / 279=95 \% \\
\mathbf{0 , 8 4}\end{array}$ & $\begin{array}{c}74 / 81=91 \% \\
\mathbf{0 . 8 3}\end{array}$ & $\begin{array}{c}87 / 93=94 \% \\
\mathbf{0 . 8 5}\end{array}$ & $\begin{array}{c}103 / 105=98 \% \\
\text { 0.90 }\end{array}$ \\
\hline $\begin{array}{l}\text { Elemento } \\
\text { nominal À } \\
\text { DIREITA do } \\
\text { núcleo na } \\
\text { posição } 2\end{array}$ & $\begin{array}{l}\text { Freq. } \\
\text { Peso } \\
\text { relativo }\end{array}$ & $\begin{array}{c}102 / 479=35 \% \\
\mathbf{0 . 2 8}\end{array}$ & $\begin{array}{c}15 / 29=52 \% \\
0.27\end{array}$ & $\begin{array}{c}39 / 56=70 \% \\
0.33\end{array}$ & $\begin{array}{c}46 / 60=77 \% \\
0.21\end{array}$ \\
\hline
\end{tabular}

Tabela 5.1. Marcas explícitas de plural nos elementos do SN em função da variável posição em relação ao núcleo do SN e posição linear a partir da esquerda - Dados de 64 falantes do Rio de Janeiro: amostra PEUL da década de 1980. (Naro \& Scherre 2007: 43, negritos dos autores)

\subsubsection{Síntese}

Embora Naro \& Scherre estejam inseridos no cenário teórico da pesquisa sociolinguística (e também da linguística histórica) e utilizem recursos técnicos da metodologia de pesquisa sociolinguística (como, por exemplo, o tratamento de dados via Varbrul), observamos uma tendência mais descritivista em sua obra, pelas seguintes razões: (1) privilegiam uma 'visão de língua' como um sistema autônomo, haja vista a utilização de teorias como a de Sapir; (2) diminuem a importância dos fatores externos à língua para a sua configuração (tais fatores são uma espécie de cenário para uma dinâmica determinada por forças internas ao sistema), como podemos observar na 'técnica' em que buscam em etapas anteriores do PE explicações para a natureza do PB atual; (3) apoiam-se em um grande volume de dados internos para construir sua 
interpretação (a descrição desses dados é a base para qualquer afirmação), principalmente dados relativos à morfossintaxe retirados das mais variadas fontes.

\subsection{Variedades Linguísticas Em Contato: Português Angolano, Português Brasileiro,}

\section{Português Moçambicano (2008) de Margarida Maria Taddoni Petter}

\subsubsection{Breve perfil biográfico do agente e visão geral da obra}

Margarida Maria Taddoni Petter graduou-se em Letras (Português/Francês) na Universidade de São Paulo (USP) (1968-1971), defendeu o mestrado na Université Nationale de Côte D'Ivoire (1983-1984) com a seguinte dissertação: Profil sociolinguistique des élèves du CM2, cuja orientação foi de Simone Lafage. Doutorouse com a tese: A construção do significado de fàni, 'pano e vestuário', em diulá (19881992), sob orientação do Prof. Dr. Izidoro Blikstein, pela Universidade de São Paulo (USP). Fez dois pós-doutorados, no Centre National de la Recherche Scientifique (2001-2002) e na Universität Bayreuth (2010). Petter é professora livre-docente do Departamento de Linguística da Universidade de São Paulo (USP) desde 2008. Ela trabalha nessa mesma instituição desde 1990.

Dirige o Grupo de Estudos de Línguas Africanas da Universidade de São Paulo (GELA) e participa do Núcleo de estudos das diversidades, intolerâncias e conflitos (Diversitas) na Faculdade de Filosofia, Letras e Ciências Humanas, como pesquisadora do preconceito e intolerância em relação à linguagem dos negros.

Coordenou o projeto de cooperação internacional "A participação das línguas africanas na constituição do português brasileiro" (2005-2008), em parceria com pesquisadores da Universidade de Campinas (UNICAMP) e do CNRS- LLACAN (Centre National de la Recherche Scientifique - Langage, Langues et Cultures d'Afrique Noire), cujo objetivo era investigar eventuais traços de línguas africanas presentes no português falado no Brasil.

É diretora do Centro de Estudos Africanos da Universidade de São Paulo (CEAUSP) desde 2013.

Sua tese de livre-docência é objeto de nossa análise. Denominada Variedades linguísticas em contato: português angolano, português brasileiro, português moçambicano (2008), apresenta-se da seguinte forma: 


\begin{tabular}{|l|}
\hline Capítulo I: História do contato (p.15- 47) \\
\hline Capítulo II: O contato linguístico: abordagens teóricas (p.48 - 70) \\
\hline Capítulo III: O léxico compartilhado (p.71 - 115) \\
\hline Capítulo IV: O léxico no modelo de Myers-Scotton (p. $116-186)$ \\
\hline Conclusão (p. 187 - 194) \\
\hline Referências bibliográficas (p. 195 - 211)
\end{tabular}

Quadro 5.2: Estrutura da obra Variedades linguísticas em contato: português angolano, português

brasileiro, português moçambicano (2008)

No capítulo 1, a autora aborda a história do contato do PE com as línguas africanas na África e no Brasil, bem como a comunicação entre o Brasil e Angola e as relações atuais entre Brasil, Angola e Moçambique.

No capítulo 2, Petter discute o quadro teórico defendido: a proposta sóciohistórica de Thomason e Kaufman (1988) e, do ponto de vista interno, as teorias de Van Coetsem (2000) e Myers-Scotton (2002).

No capítulo 3, “A constatação de que o léxico é o ponto de convergência do contato linguístico orienta a análise" (Petter 2008: 13), Petter investiga o vocabulário básico de origem africana comum às variedades do português analisadas, quais sejam: Português Angolano (PA), Português Brasileiro (PB) e Português Moçambicano (PM). A pesquisadora também apresenta aqui a sua metodologia.

No capítulo 4, Petter discute estruturas do PA, PM e PB, a partir do modelo de análise de Myers-Scotton.

A pesquisadora propõe que o contato linguístico com as línguas bantas produzido em Angola, no Brasil e em Moçambique, promoveu as semelhanças entre essas variedades:

Este trabalho focaliza as variedades do português formadas na África e no Brasil, chamando a atenção para o fato de que as diferentes situações de contato, em épocas diversas, mas envolvendo o português e um conjunto de línguas muito próximas, as do grupo banto, produziram alguns resultados semelhantes nos níveis lexical e morfossintático que nos permitem defender a existência de um continuum afro-brasileiro de português (Petter 2008: VI, grifos do autor) 


\subsection{2 'Horizonte de retrospeção'}

Ao analisar o 'horizonte de retrospeção' assumido pela autora, podemos observar tanto sua relação com autores e produções mais antigas, quanto com seus colegas pesquisadores contemporâneos. A propósito dos estudos da relação do PB com o PE, ela afirma:

No Brasil essa questão é antiga e é sempre renovada. Se no passado se priorizavam as questões lexicais, hoje os trabalhos destacam as diferenças sintáticas entre o PB e o PE. Os resultados pioneiros sobre o português falado no Brasil tratavam de apontar as singularidades da língua transplantada para a América, os chamados brasileirismos (Visconde de Pedra Branca, 1826; Macedo Soares, 1888; João Ribeiro, 1889; Renato Mendonça, 1933; Jacques Raimundo, 1933) (Petter 2008: 87)

Os autores por nós analisados, Macedo Soares (1888), Renato Mendonça (1933) e Jacques Raimundo (1933), são considerados por Petter como de viés lexicalista e também nacionalista.

Há uma referência também a Silva Neto, por História da Língua Portuguesa (1952), mas relacionada à análise da variedade angolana da língua portuguesa:

\footnotetext{
Por outro lado, sobre a língua portuguesa do final do século XIX em Angola, há uma referência importante, encontrada em Silva Neto (1952). O autor, após reconhecer o "novo esforço recolonizador português", que cresceu, sobretudo, a partir da independência brasileira (1952: 516), retoma uma citação de Schuchardt sobre uma gramática do bundo (quimbundo), de Souza e Oliveira e Alves de Castro Francina (1864), que inclui um comentário sobre a pronúncia do português de Angola, confirmando a presença de brasileiros nessa região da África ao mesmo tempo em que compara a expressão em português dos habitantes das duas colônias. (Petter 2008: 46-7)
}

Ainda em sua reconstrução da história dos trabalhos sobre o contato, Petter destaca o registro da 'língua de preto' nas obras literárias de Gil Vicente: $O$ Clérigo da Beira, Frágoa de Amor (1524) e Nau d'Amores (1587). Tal registro seria objeto de análise de Carolina Michaëlis de Vasconcelos (1923), W. Geise (1932), Leite de Vasconcelos (1933), Paul Tessyer (1959) e Naro (1978). Embora a autora não mencione, também Mendonça (1933), Raimundo (1935[1933]) e Silva Neto (1950) operaram com esse material.

Vê a maior parte dos trabalhos como de natureza contrastiva, entre o PB e o $\mathrm{PE}$, tanto na perspectiva sincrônica quanto diacrônica. Recentemente, para a autora, o enfoque da análise estaria nas semelhanças morfossintáticas entre o PB e as línguas crioulas de base portuguesa, como se observaria nos trabalhos de Baxter e Lucchesi. 
Para Petter, ambas as abordagens (identificadas por Baxter \& Lucchesi e por Naro \& Scherre) são legítimas. No entanto, ela descarta a hipótese da crioulização, tendo em vista a ausência de documentos e evidências no Brasil que a comprovem.

Quanto à abordagem da continuidade da "deriva secular" vinda da Europa, defendida por Naro \& Scherre, Petter, com base na teoria de Thomason e Kaufman (1988), afirma:

Aceita-se que houve uma certa manutenção da deriva românica, concordando, no entanto, com a ressalva de Thomason e Kaufman quando afirmam que a presença de traços herdados não é sempre explicada adequadamente só pelo fato de se indicar sua origem genética, pois a manutenção ou a inovação podem ser motivadas por fatores externos. (Petter 2008: 9)

Petter cita também os trabalhos de Yeda Pessoa de Castro e Tania Alkmin ${ }^{15}$, acatando seus resultados; com essa última, Petter, inclusive, realizou trabalhos em parceria.

\subsection{3 'Programa de investigação'}

\subsubsection{1 'Visão de língua'}

Petter (2008) reconhece que fatores linguísticos e sociais estão interligados ao analisar o fenômeno do contato linguístico. Tal premissa é observada em suas próprias escolhas teóricas que tentam abarcar essa complexidade: do ponto de vista externo, reconhecido, pois, como relevante pela autora, são adotadas as teorias de Thomason \& Kaufman (1988), e, por outro lado, Coetsem (1988, 2000) e Myers-Scotton (2002) tornam-se referências para lidar com a perspectiva interna.

Thomason \& Kaufman, resumidamente, reconhecem que os fatores sociais têm ‘maior peso' no contato linguístico do que a estrutura das línguas. Nesse sentido, eles se

\footnotetext{
15 Tania Maria Alkmin "Possui graduação em Letras pela Universidade Federal do Rio de Janeiro (1971), mestrado em Linguística pela Universidade Estadual de Campinas (1975), doutorado em Linguística pela Université Paris Descartes (1984) e pós-doutorado pela Centre National de la Recherche Scientifique (1997). Foi Professor Associado - MS5 da Universidade Estadual de Campinas. Atualmente é professora aposentada na UEFS. É Membro de corpo editorial da Estudos da Língua(gem), Membro de corpo editorial da Revista de Estudos da Linguagem e Membro de corpo editorial da Liames (UNICAMP). Tem experiência na área de Linguística, com ênfase em Sociolinguística e Dialetologia. Atuando principalmente nos seguintes temas: Língua crioula, Crioulo português, Sociolinguística". (texto retirado do currículo lattes da autora http://lattes.cnpq.br/8437404856512094., visualizado em 31.10.2014).
} 
opõem aos estruturalistas e gerativistas ao considerar o contexto histórico em que as situações de contato ocorrem (Petter 2008: 50).

Já Coetsem, inserido na Linguística Histórica, defende que o contato é, sobretudo, um fenômeno individual e, portanto, deve-se analisá-lo, sobretudo, a partir de seus mecanismos de transmissão.

Outra referência: Myers-Scotton também reconhece a importância dos fatores sociais. Seu modelo explica os fenômenos por meio da aquisição da linguagem e de contato de línguas (aquisição de segunda língua). Todos os autores citados dão relevância ao exame do léxico.

A partir desse arcabouço teórico, Petter arcabouço de teorias da gramática lexicalistas, Petter centra-se na análise do léxico como forma de entrada para as questões de morfossintaxe e exclui o domínio fonético-fonológico:

\begin{abstract}
A proposta aqui defendida concorda com teorias que vêem a mudança linguística como um resultado da aquisição da linguagem: durante esse processo, fatores externos, como o acesso a dados linguísticos divergentes, podem atuar fazendo emergir gramáticas concorrentes (Petter 2008: VI, resumo)
\end{abstract}

A língua, portanto, é vista como um todo complexo, articulado por processos internos e externos.

\title{
5.3.3.2 'Incidência de análise'
}

A partir do arcabouço da teoria da gramática, de hipótese lexicalista, Petter centra-se na análise do léxico e da morfossintaxe e exclui o fonético-fonológico "[...] por solicitar uma investigação independente que parte de dados coletados adequadamente, conforme uma proposta teórico-metodológica definida" (Petter 2008: 10) e ressalta que "[...] fatos esparsos (concordância, regência verbal, pronomes átonos) observados no PA, PB e PE são analisados no âmbito de um quadro geral, unitário." (Petter 2008: 14).

A pesquisadora analisa o léxico, pois o considera como um ponto de convergência do contato linguístico entre as variedades angolana, brasileira e moçambicana do português com as línguas africanas. Ou seja, para Petter, o léxico é uma evidência a favor da hipótese do contato linguístico entre as variedades mencionadas (Petter 2008: 69-70). Nesse sentido, Petter apresenta vocábulos e 
expressões comuns às variedades brasileira e africanas do Português, como no exemplo abaixo:

Capinar vb., Ln. Significa arrancar, extrair o capim (erva) com um enxada. Est. neutro. N.

Mesmo emprego no PA e PB, pois deriva de capim, vocábulo emprestado do tupi e difundido pelos portugueses em toda a África lusófona.

Carregar (alguém) vb., Ls, "A ambulância carregou a doente". Significa transformar, levar. Inf. N.

Celular cel. n., Ln. Telefone celular, mas telemóvel, do PE, também é utilizado, embora com tendência menos freqüente. Prov. do inglês cell. A forma abreviada cel tb. é muito frequente. "Não pude desmarcar o encontro porque o meu cel estava sem carga". Est. neutro. R.

Não se identifica no PB a forma reduzida $c e l$.

(Petter 2008: 94, grifos da autora)

Ela afirma que há elementos para suspeitar de que tenha havido interferência nos níveis fonológico, morfológico e sintático, embora não se disponha, ainda, de estudos conclusivos a esse respeito.

\subsubsection{3 'Fontes'}

Com relação às fontes, materiais selecionados para a análise, Petter retira dados de "[...] (i) trabalhos científicos (teses, dissertações, ensaios) e (ii) corpora de língua oral e escrita, localizados em publicações e banco de dados disponíveis na internet" (Petter 2008: 72).

Os trabalhos científicos consultados foram, sobretudo, aqueles de publicação recente. Já nos corpora, há um conjunto de dados orais e escritos organizado pelo Centro de Linguística da Universidade de Lisboa (CLUL), jornais africanos disponíveis na internet, além dos dados presentes nos trabalhos científicos selecionados. Especificamente sobre o PB, Petter consultou dados do Projeto NURC (Norma Urbana Culta), trabalhos sobre o dialeto rural e de comunidades quilombolas, bem como os 
seguintes dicionários: Novo Aurélio do século XXI (1999), Dicionário Houaiss da língua portuguesa (2001) e Dicionário de usos do português do Brasil (2002).

Também Petter, como os demais autores analisados, se queixa da ausência de dados históricos que sustentem interpretações propostas: “Os dados que interessariam ao linguista, como o número de escravos bilíngues, de escravos que só falassem uma língua africana e dos que só falavam o português não estão disponíveis e é impossível recuperá-los" (Petter 2008: 32).

\subsubsection{4 'Técnica'}

A partir de uma "metodologia qualitativo-descritiva", termos da autora, ela busca analisar o PB em conjunto com as variedades africanas:

\footnotetext{
A língua portuguesa chegou primeiro à África e quando aportou na América já trazia marcas do contato com línguas africanas. Por outro lado, o português que foi para Angola e Moçambique, no século XIX, já estava marcado pela convivência brasileira de três séculos (Petter 2008: VI, resumo)
}

Segundo ela, essa seria uma deficiência dos trabalhos até então existentes, seria necessário buscar como as variedades se aproximam e como divergem, levando em conta que os contatos se estabeleceram em épocas e situações diversas.

Petter constitui um vocabulário comum em uso às três variedades do Português (PB, PA e PM), organizados segundo os processos morfológicos e também de uso, como no exemplo:

BARRACA, n., Ls, "O João passou toda a noite a beber na barracada do tio Nhaca". Significa quiosque, mini-bar instalado numa construção de madeira, chapa metálica ou blocos de cimento. Os contentores têm igualmente sido aproveitados para instalar barracas. A barraca funciona, regra geral, em regime de comércio informal. Coloq. N. (Petter 2008: 93, grifos da autora).

\subsubsection{Síntese}

Podemos situar a obra de Petter (2008) como híbrida entre uma tendência descritivista e uma tendência sociocultural, com prevalência da primeira tendência: a autora tem como 'visão de língua' a inter-relação entre fatores sociais e linguísticos na análise que realiza do contato linguístico; o léxico é escolhido como foco da análise, uma vez que a autora baseia-se na teoria da gramática de hipótese lexicalista, já que o 
léxico é tido como ponto de contato entre as variedades selecionadas; as 'fontes' são de natureza diversa, e os dados são analisados, segundo uma "metodologia qualitativodescritiva" ('técnica') que organiza o vocabulário comum das variedades do Português em questão. 


\section{4 "African Languages and Brazilian Portuguese: A new approach", de Yeda Antonita Pessoa de Castro (2009)}

\subsubsection{Breve perfil biográfico do agente e visão geral da obra}

Yeda Antonita Pessoa de Castro graduou-se em Letras Anglo-Germânicas na UFBA (1954-1958) e fez mestrado em Ciências Sociais na mesma universidade (19691972), com a dissertação Terminologia religiosa e o falar cotidiano em uma casa de culto afro-brasileira, sob orientação de Joselice Macedo de Barreiros e Olasope Oyelaran.

Defendeu mestrado e doutorado no continente africano. Na University of Ifé (hoje Obafemi Awolowo University, Nigéria), defendeu o mestrado (1972-1974) em Línguas Africanas, sob a orientação Olasope Oyelaran, aparentemente aprofundando o trabalho anteriormente desenvolvido no Brasil em Ciências Sociais dois anos antes, já que o novo mestrado leva o título The Religious Terminology and Everyday Speech Vocabulary of an Afro-Brazilian Cult House, tradução para o inglês do título daquela outra dissertação. Defendeu o doutorado (1974-1976), intitulado De l'intégration des apport africans dans les parlers de Bahia au Brésil, sob orientação de Jean-Pierre Angenot, na Université National du Zaire (República Democrática do Congo). Realizou pós-doutorado na Universidade Agostinho Neto (Angola) em 2012.

A autora, que se autodenomina uma etnolinguista, destaca as seguintes publicações: "Falares Africanos na Bahia: um vocabulário afro-brasileiro (Academia Brasileira de Letras / Topbooks Editora, 2001, 2a. ed. 2005), segundo ela, aceito pela crítica como a obra mais completa já escrita sobre línguas africanas no Brasil, um livro que já se tornou um clássico na matéria, e A língua mina-jeje no Brasil: um falar africano em Ouro Preto do séc. XVIII (Fundação João Pinheiro, Secretaria de Cultura de Minas Gerais, 2002, Coleção Mineiriana), também pioneiro no estudo das línguas Ewe-fon no Brasil, além de inúmeros artigos e conferências, publicados em revistas científicas, anais de congressos, etc., no Brasil e no exterior." 16

É consultora técnica em Línguas Africanas do Museu da Língua Portuguesa na Estação da Luz em São Paulo e na Pró-Reitoria de Extensão na Universidade do Estado da Bahia (UNEB). Membro da Academia de Letras da Bahia, do Comitê Científico

16 Trecho e demais informações retiradas do currículo lattes da autora. Disponível em http://lattes.cnpq.br/9378529199920162 e consultado pela última vez em 09.11.2014. 
Brasileiro do Projeto Rota do Escravo da UNESCO e do Conselho Consultivo do Patrimônio Cultural do IPHAN em Línguas e Culturas Africanas.

“African Languages and Brazilian Portuguese: a new approach” é um artigo de 9 páginas (p. 47-56) publicado nos anais do Special World Congress of African Linguistics: Exploring the African Connection in the Americas (Wocal), $6^{\text {a }}$ edição do congresso internacional, que ocorreu na Faculdade de Filosofia, de Letras e Ciências Humanas entre os dias 11 a 15 de agosto de 2008. Esse volume foi editado por Margarida Petter e por Ronald Beline Mendes, professores do Departamento de Linguística da USP.

Esse evento contou com a participação de 185 pesquisadores de 28 países e teve como foco a participação das línguas africanas na formação das línguas faladas na América. $\mathrm{O}$ volume que resultou desse evento conta com 21 artigos divididos em "Plenary Papers"; que discutem o tema do evento, incluído aqui o artigo de Pessoa de Castro; "Phonects and Phonology", "Lexicon", "Morphology and Syntax" e "Sociolinguistics".

O artigo "African Languages and Brazilian Portuguese: a new approach" está subdivido nas seguintes seções:

\begin{tabular}{|l|}
\hline Sessão I: “The slave-trade in Brazil” (p. 47-48) \\
\hline Sessão II: “Socio-historical factors” (p.48-50) \\
\hline Sessão III: “Afro-Brazilian religions” (p.50 - 51) \\
\hline Sessão IV: “Bantu legacy” (p. 51-52) \\
\hline Sessão V: “West-African legacy” (p. 52-54) \\
\hline Sessão VI: “'Brazilian Portuguese” (p. 54 - 55) \\
\hline Sessão VII: "References” (p. 55 - 56)
\end{tabular}

Quadro 5.3: Estrutura do artigo "African Languages and Brazilian Portuguese: a new approach"

Esse artigo foi selecionado por estar presente nos anais de um dos principais eventos internacionais da área de pesquisa, o Wocal, evento realizado no Brasil cujos anais foram editados por pesquisadores brasileiros. Também consideramos que esse artigo reúne as principais ideias da autora sobre o tema do contato do PB com as línguas africanas, defendidas ao longo de sua carreira acadêmica. 


\subsection{2 'Horizonte de retrospeção'}

O artigo apresenta poucas referências bibliográficas incluídas no corpo do texto, ainda que a seção "References" conte com 20 itens, sendo oito deles textos da própria autora. Os textos mencionados no corpo do texto são:

1) Yeda Antonita Pessoa de Castro por Falares africanos na Bahia (2005), a respeito das línguas africanas faladas no Brasil;

2) Amélia Mingas por Interferência do kimbundo no português falado em Lwanda (2000), sobre o sistema de vogais do PA (Português Angolano);

3) Joaquim Mattoso Câmara Jr por Princípios de linguística Geral (1973[1954]), sobre o sistema de vogais no $\mathrm{PB}$;

4) Serafim da Silva Neto por Introdução ao estudo da língua portuguesa no Brasil (1963), a respeito da obra Arte da Língua de Angola de Pedro Dias (1697)

Quadro 5.4 Referências explícitas em Castro (2009)

Dentre aqueles mencionados nas "References", sem uso explícito no corpo do texto, destacamos a obra de Jacques Raimundo, O elemento afro-negro na Língua Portuguesa (1933), que foi analisada por nós no Capítulo 4.

\subsection{3'Programa de investigação'}

\subsubsection{1 'Visão de língua'}

A língua é considerada como fenômeno cultural e social, uma vez que Castro busca compreender o papel dos negros africanos na configuração cultural e linguística do Brasil, como ela explica no trecho:

Taking into consideration that language and culture are the fundamental traits for the building up of the identity of a people, one may conclude that the African space has played an outstanding role in the process of configuration of the Portuguese language in Brazil and of Brazilian culture (Castro 2009: $47)^{17}$

17 "Levando em consideração que língua e cultura são os traços fundamentais para a construção da identidade de um povo, pode-se concluir que o espaço africano teve papel proeminente no processo de configuração do Português no Brasil e na cultura brasileira" (tradução nossa) 
No estudo a que se propõe Castro, os fatores externos, como os contatos étnicos, são tomados como fundamentais para o surgimento do Português Brasileiro e da cultura brasileira.

\subsubsection{2 'Incidência'}

Segundo Castro, o contato se deu por meio da transmissão de valores culturais, étnicos e estéticos. Nesse sentido, sua análise recai sobre as manifestações da cultura, como o samba, a capoeira, religiões como a Umbanda e o Candomblé, entre outras, bem como sobre o léxico, eleito pela autora como aspecto que melhor revela a expressão de uma cultura através da língua.

O vocabulário do PB seria um testemunho do contato com as línguas africanas, especialmente as do grupo bantu. São exemplos da autora:

-Toponímia local, isto é, as designações relativas aos lugares, tais como Dembo, Macaco, Osengo;

-Termos associados à escravidão: senzala, mucama, moleque, carimbo, banzo;

-Festas populares: Congos e Congadas (Castro 2009: 51).

Outra evidência relativa ao contato do PB com as Línguas Africanas e elemento de análise de Castro é o sistema vocálico do PB. Segundo ela:

[...] the vowel system of the Brazilian Portuguese practically coincides with the seven nasal vowels (reconstruted from the proto-bantu) of a number of present day bantu Languages, such as Kimbundu and Kikoongo, at the phonic level and, exception to the nasal consoant, the vowel is always the nucleus of syllables. (Castro 2009: 54) ${ }^{18}$

Nesse campo, Castro propõe que as diferenças entre o PB e o PE são resultado das grandes similaridades entre a estrutura linguística do Português antigo e popular com os aspectos mais antigos das línguas do grupo banto.

\footnotetext{
18 “[...] o sistema vocálico do Português Brasileiro praticamente coincide com as sete vogais nasais (reconstruídas do proto-bantu) presentes nas Línguas do grupo bantu hoje, como o Quimbundo e o Quicongo, no nível fônico e, com exceção da consoante nasal, a vogal é sempre o núcleo da sílaba" (tradução nossa).
} 


\subsubsection{3 'Fontes'}

Com relação aos aspectos mais propriamente linguísticos, figuram em seu trabalho dados lexicais correntes em religiões afro-brasileiras. Não há, contudo, uma identificação das fontes de que foram extraídas as formas linguísticas apresentadas. Menciona-se, genericamente, sua presença em 'língua de santo'. Reproduzimos uma parte desses itens lexicais abaixo (cf. Castro 2009: 50-1):

(1) Língua de santo

\begin{tabular}{|l|l|l|l|}
\hline "Nation" & Jeje-Mina & Nagot-Ketu & Congo-Angola \\
\hline saint & vodum & Orisha & Nkisi \\
\hline priestess & humbono/done & Iyalorisha & mameto/nengwa \\
\hline priest & dote & Babalorsha & tateto/tata \\
\hline$\cdots$ & $\cdots$ & $\cdots$ & $\cdots$ \\
\hline $\begin{array}{l}\text { Language group } \\
\text { Geographical region }\end{array}$ & Gbe & $\begin{array}{l}\text { Bantu } \\
\text { Sub-equatorial Africa }\end{array}$ \\
\hline $\begin{array}{l}\text { Languages } \\
\text { Ewe, Fon, Gun, } \\
\text { Mahi... }\end{array}$ & $\begin{array}{l}\text { Yoruba } \\
\text { (Anagot) }\end{array}$ & Bantu \\
\hline
\end{tabular}

Também são usados como fontes os quadros das vogais do PB, proposto por Câmara Jr. (1973), e do quimbundo, apresentado em Mingas (2000).

\subsubsection{4 'Técnica'}

A 'técnica' utilizada, considerada pela autora como uma nova abordagem do tema, consiste em analisar a questão:

[...] from a realistic point of view focusing the African descents is Brazil as performers rather than neglected characters that were placed aside the History of the country due to the imposition on them of the "Eurocentric varnish" by the most conservative classes of the Brazilian Society, including the academic studies related to African languages. (Castro 2009:47) ${ }^{19}$

\footnotetext{
19 “" [...] de um ponto de vista realista que foca nos descendentes de africanos no Brasil como agentes mais do que personagens negligenciados que foram colocados à parte na História do país devido à imposição do "verniz eurocêntrico" pela maioria conservadora da sociedade brasileira, incluindo aqui os estudos acadêmicos relacionados às línguas africanas" (tradução nossa)
} 
Castro busca, portanto, analisar o contato do PB com as línguas africanas, a partir do negro, visto como um protagonista da cultura. Para isso, ela leva em conta as circunstâncias socio-históricas, tais como o fato da maioria da população negra escravizada já ter tido relação com o Português dos colonizadores, a distribuição geográfica difusa do comércio doméstico de escravos, entre outros, além dos aspectos culturais, como: símbolos da identidade nacional como o samba, a capoeira, as religiões afro-brasileiras, entre outros, que juntos contribuíram para o que ela denomina de 'emergência da interação étnica e cultural'.

Nesse sentido, os aspectos linguísticos fundamentam a construção da identidade brasileira e constituem-se como uma evidência do contato do PB com as línguas africanas.

\subsubsection{Síntese}

$\mathrm{O}$ artigo que analisamos parece ter um tom programático, isto é, parece ter o propósito de oferecer orientações sobre como o tema deve ser trabalhado. Podemos classificar a abordagem apresentada como de tendência 'sociocultural', em que a 'visão de língua' está atrelada a fatores externos, notadamente sociais e culturais; assim, a abordagem 'incide' sobre a expressão da língua por meio da cultura e tem como 'técnica' a inserção dos fatos linguísticos no contexto de uma análise mais ampla da sociedade.

\subsection{O Português Afro-Brasileiro (2009), organizado por Dante Lucchesi, Alan}

\section{Baxter e Ilza Ribeiro}

\subsubsection{Perfis biográficos dos agentes e visão geral da obra}

Dante Eustachio Lucchesi Ramacciotti bacharelou-se em Letras Vernáculas na Universidade Federal da Bahia (1984-1986). Concluiu o mestrado em Linguística Portuguesa Histórica, na Universidade de Lisboa (1989-1993), com a seguinte dissertação: Sistema, Mudança e Linguagem: um percurso da linguística neste século, sob orientação da Prof ${ }^{a}$ Dr $^{a}$ Rosa Virgínia Mattos e Silva. Desenvolveu a tese em Linguística $A$ variação na concordância de gênero em uma comunidade de fala afro- 
brasileira: novos elementos sobre a formação do português popular do Brasil, na Universidade Federal do Rio de Janeiro (UFRJ), no período de 1996-2000, sob orientação do Prof. Dr. Anthony Julius Naro e co-orientação da Prof ${ }^{a}$ Dr $^{a}$ Ilza Ribeiro.

Suas linhas de pesquisa são: Constituição Histórica do Português, Diversidade Linguística no Brasil, História da Língua Portuguesa e Contato entre Línguas na Formação do Português Popular Brasileiro.

Compõe o corpo editorial das seguintes revistas: Revista Virtual de Estudos da Linguagem, Papia (Brasília) e Confluência (Rio de Janeiro). Atualmente, é Professor Titular de Língua Portuguesa na Universidade Federal da Bahia (UFBA), pesquisador 1C do CNPq e coordena o Projeto Vertentes do Português Popular do Estado da Bahia, cujo objetivo é identificar os efeitos do contato entre línguas em comunidades afrobrasileiras.

Dentre suas publicações, Lucchesi destaca os seguintes livros: Sistema, Mudança e Linguagem (1998, 2004) e O Português Afro-Brasileiro (2009), organizado em conjunto com Alan Baxter e Ilza Ribeiro, que analisamos aqui.

Alan Norman Baxter é um pesquisador australiano graduado em Romance Languages and Linguistics na La Trobe University (Austrália), onde também obteve o título de mestre em Linguística Hispânica, com a dissertação El Modo Subjuntivo en los Complementos Oracionales en Español (1974-1978), orientado pelos professores Dr. Maya Brummerhurst e Dr. R. W. Thompson. Doutorou-se em linguística com a tese $A$ Grammar of Kristang (Malacca Creole Portuguese), na Australian National University (1979-1983), sob orientação do Dr. Donald C. Laycock e co-orientação dos professores Dr. Tom E. Dutton e Dr. S. A. Wurm.

Desde 2011 é professor adjunto da Universidade Federal da Bahia (UFBA). Já foi professor da Universidade de Macau (2000-2004; 2006-2011), da Flinders University of South Australia (2005-2006), da La Trobe University, Austrália (19841989; 1990-1991; 1991-2000), da Universidade de Lisboa (1989-1990).

É membro do conselho editorial das seguintes revistas: Journal of Pidgin and Creole Languages, Papia (Brasília) e Revista de Crioulos de Base Lexical Portuguesa e Espanhola e atua nas subáreas da Sociolinguística e Dialetologia, principalmente nos temas: línguas crioulas de base portuguesa, crioulização, português afro-brasileiro, português africano (São Tomé), português de Macau (Macau, China), português em contexto pós-colonial, aquisição de português L2 e L1 em situações de contato linguístico. 
Ilza Maria de Oliveira Ribeiro graduou-se em Letras na Universidade Estadual de Feira de Santana (1970-1973), fez mestrado em Letras e Linguística na Universidade Federal da Bahia (UFBA), entre 1984 e 1988, com a dissertação O papel do traço [+acordo] em construções com o infinitivo flexionado, sob orientação das professoras Claiz Passos e Maria Emiliana Passos. Desenvolveu tese de doutorado, entre 1990 e 1995, em Linguística, na Universidade Estadual de Campinas (UNICAMP), denominada $A$ sintaxe da ordem no português arcaico; o efeito $V 2$, sob orientação da Prof. Dr. Charlotte Marie Chambelland Galves. A pesquisadora fez também dois pósdoutorados: na Universidade de Campinas (UNICAMP), no período de 2006 a 2007, e na Universidade de São Paulo (USP), em 2011.

Desde 2003, é professora adjunta da Universidade Federal da Bahia (UFBA) e atua na subárea Sintaxe Gerativa, principalmente investigando os seguintes temas: variação linguística, história do português, gramática normativa, teoria da gramática.

Além do livro que analisamos, a autora organizou também Para a história do português brasileiro. Novos dados, novas análises (2006), ao lado de Tânia Lobo, Zenaide Carneiro e Norma Almeida.

O livro O Português Afro-brasileiro (2009) está dividido em duas partes: $1^{\text {a }}$ parte: O contexto sócio-histórico e os fundamentos teóricos e metodológicos (p. 41 164); $2^{\mathrm{a}}$ parte: A gramática do português afro-brasileiro (p. 167 - 511), como apresentado na tabela abaixo:

\begin{tabular}{|c|}
\hline Apresentação (p. 15-22) \\
\hline Os autores (p. 23-25) \\
\hline Introdução (Dante Lucchesi) (p. 27 - 37) \\
\hline $\begin{array}{l}\text { 1a parte: O contexto sócio-histórico e os fundamentos teóricos e metodológicos (p. } 41 \\
\text { - 164) }\end{array}$ \\
\hline 1. História do contato entre línguas no Brasil (Dante Lucchesi) (p. $41-73$ ) \\
\hline $\begin{array}{l}\text { 2. O português afro-brasileiro: as comunidades analisadas (Dante Lucchesi, Alan } \\
\text { Baxter, Jorge Augusto Alves da Silva, Cristina Figueiredo) (p. } 75-100)\end{array}$ \\
\hline 3. A transmissão linguística irregular (Dante Lucchesi e Alan Baxter) (p. 101 - 124) \\
\hline $\begin{array}{l}\text { 4. Teorias da estrutura e da mudança linguísticas e do contato entre línguas (Dante } \\
\text { Lucchesi e Ilza Ribeiro) (p. } 125-154 \text { ) }\end{array}$ \\
\hline
\end{tabular}




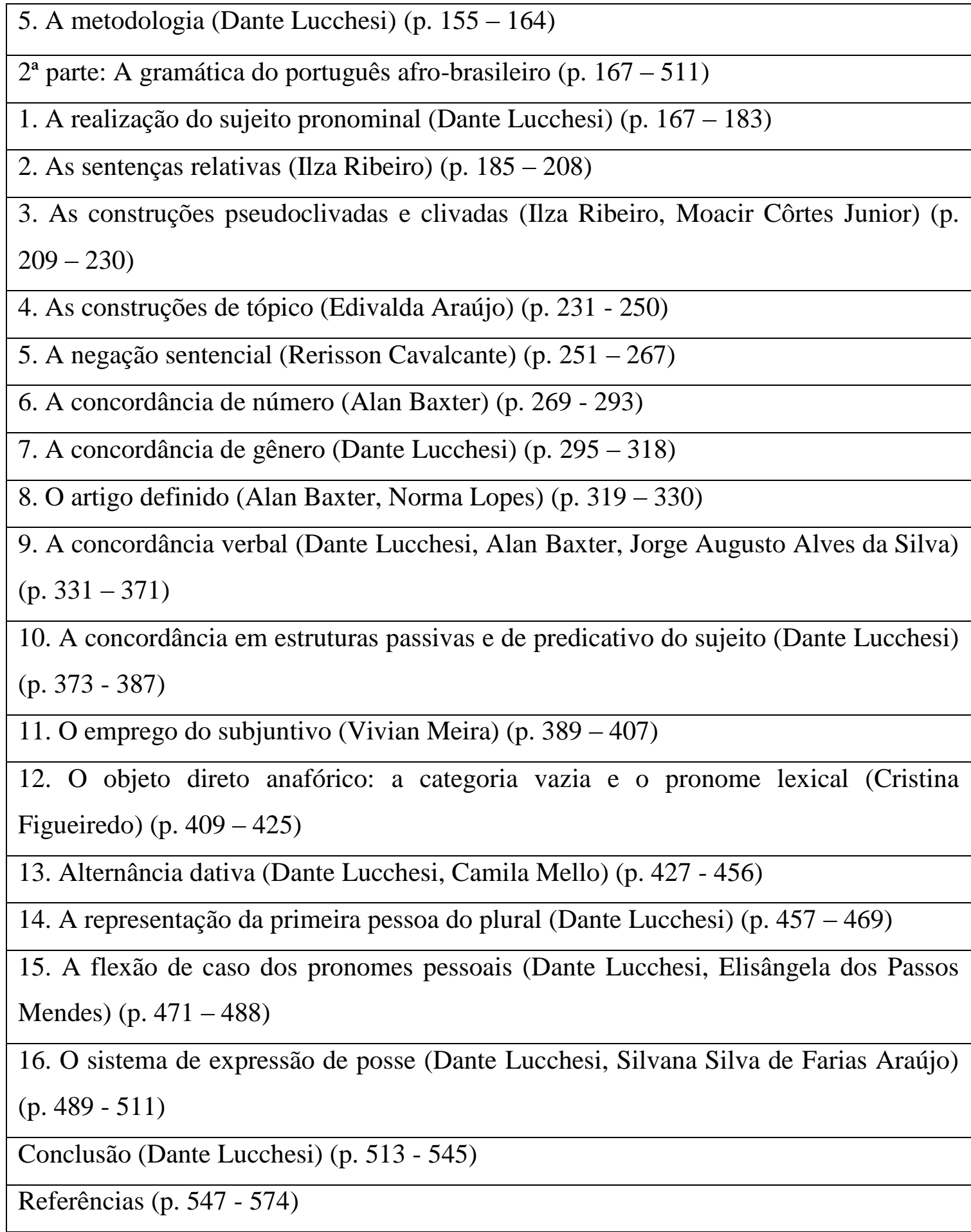

Quadro 5.6: Estrutura da obra O Português Afro-brasileiro (2009)

Como se verifica por essa reprodução do índice, os seguintes pesquisadores também publicaram na obra: Jorge Augusto Alves da Silva, Cristina Figueiredo, Moacir 
Côrtes Junior, Edivalda Araújo, Rerisson Cavalcante, Vivian Meira, Camila Mello, Elisângela dos Passos Mendes e Silvana Silva de Farias Araújo ${ }^{20}$.

A obra O Português Afro-brasileiro (2009) é o resultado de mais de quinze anos de pesquisa do Projeto Vertentes, vinculado ao Departamento de Letras Vernáculas da Universidade Federal da Bahia (UFBA). O projeto tem como principal objetivo:

[...] traçar um panorama sociolinguístico do português popular do Estado da Bahia, considerando os seguintes parâmetros: a relevância do contato entre línguas na sua formação histórica, por um lado, e os processos atuais de difusão linguística a partir dos grandes centros urbanos, por outro. Esses dois parâmetros definem os dois grandes vetores que atuam sobre a fala popular atualmente, condicionando os processos de variação e mudança que caracterizam e individualizam as diversas variedades do português popular no país. (http://www.vertentes.ufba.br/home)

Trata-se da primeira fase do Projeto, que tem como objetivo investigar o Português Popular do Brasil das comunidades rurais afro-brasileiras isoladas da Bahia, algumas remanescentes de antigos quilombos. As demais etapas focalizam: o Português Popular do interior da Bahia e o Português Popular da cidade de Salvador.

Selecionamos para análise o capítulo "A concordância de número" (p. 269 293), de Alan Baxter, pois trata do mesmo tema discutido no capítulo de Naro \& Scherre (2009) que analisamos ${ }^{21}$. Com a escolha, pretendemos encontrar elementos para comparar duas diferentes perspectivas sobre a questão.

Nele, Baxter analisa a comunidade de Helvécia (Bahia) e a comunidade dos tongas da roça Monte Café, na República de São Tomé e Príncipe, na África. Elas foram selecionadas porque ambas manifestam a variação na concordância de número, além disso a comparação se dá por conta de que:

(ii) são variedades de português que surgiram em microssociedades de trabalho 'controladas' e bastante fechadas: escravatura, num caso, e trabalho contratado, no outro; (iii) surgiram em contextos demográficos com altas proporções de africanos e afrodescendentes contratados para administradores; (iv) os seus antepassados africanos adquiriram o português pelo contato, principalmente a partir de modelos falados por colegas trabalhadores e, em parte, a partir de modelos falados pelos administradores (BAXTER; LUCCHESI, 1999; BAXTER, 2002); (v) houve uma presença de português falado como segunda língua (L2) em fases anteriores, (vi) houve presença de línguas africanas dos grupos kwa e banto. (Lucchesi, Baxter \& Ribeiro 2009: 270-1)

\footnotetext{
20 Pesquisadores da UFBa: mestrandos e doutorandos do Programa de Pós-Graduação em Letras e Linguística da UFBa - PPGLL-UFBa e estudantes de graduação com bolsa de Iniciação Científica.

${ }^{21}$ Note-se, na tabela de conteúdos da obra, que não há em Lucchesi, Baxter e Ribeiro (2009), nenhum capítulo referente à análise lexical propriamente dita como em Castro (2009) e Petter (2009), nem de natureza fonético-fonológica, como em Castro (2009).
} 


\subsection{2 'Horizonte de retrospeção'}

Baxter considera que nas investigações sobre a variação do PB, especialmente sobre o fenômeno da concordância de número plural no sintagma nominal, há duas perspectivas dominantes: a "linha contatista" e a "linha derivista" (Baxter 2009: 269). A primeira atribui um papel fundamental aos contatos linguísticos no Brasil e a "potenciais processos de crioulização no desenvolvimento do PL no SN e correlaciona essa variável com outros fenômenos morfossintáticos no PB considerados indícios de reestruturações que teriam as mesmas fontes" (Baxter 269). Nessa linha, atuam Gregory Guy (1981a, 1981b, 2005) e John Holm (1987, 1992). Já a "linha derivista" analisa o fenômeno como um padrão da concordância em variedades do PE, modelo do qual o PB se originou. Seguem essa linha Naro \& Scherre (1993, 2000, 2007).

\subsection{3 'Programa de investigação'}

\subsubsection{1 'Visão de língua'}

A visão de língua sustentada em Lucchesi, Baxter \& Ribeiro (2009) é a de que há uma inter-relação entre aspectos internos e externos da análise linguística. $\mathrm{Na}$ descrição que pretendem realizar do Português Afro-Brasileiro, denominação que dá título à obra, os autores buscam descrever os fenômenos linguísticos sempre em consonância com o contexto em que estão inseridos. Mais do que isso: a obra se apresenta como engajada politicamente:

\footnotetext{
Por acreditar que a ciência não pode fugir aos seus compromissos sociais, este livro se irmana, não apenas às ações afirmativas, que ganharam destaque nos últimos anos, mas a todos os movimentos que lutam pela justiça social e pela verdadeira liberdade neste país, mesmo que contenha apenas análises de aspectos da morfossintaxe da fala das comunidades rurais afro-brasileiras isoladas do interior do Estado da Bahia. (Baxter 2009: 21)
}

Ou seja, se reconhecem, a partir do trabalho que desenvolvem na disciplina Linguística, como atuantes na sociedade.

Ainda que Baxter assuma uma série de assunções da linguística gerativa, ele tem como pressuposto que a organização social influencia a organização linguística. Mais especificamente sobre a análise linguística em questão, Baxter analisa a variável 
linguística da marcação do plural correlacionada à variável extralinguística da faixa etária.

\subsubsection{2 'Incidência'}

A análise de Baxter incide sobre um fenômeno da morfossintaxe: a concordância de número no Sintagma Nominal; mais especificamente, ele investiga: (a) a posição linear do item número plural em relação ao núcleo e função, variável independente que foi selecionada pelo programa VARBRUL e (b) "variável marcas precedentes de PL — considerada por Scherre $(1989,1998)$ como essencial para a caraterização da variável PL - e de alguns aspectos das variáveis sociais, sobretudo faixa etária, 'etnia' dos pais, e gênero" (Baxter 2009: 272).

Ainda que uma grande quantidade de dados seja mobilizada na análise, poucos dados são efetivamente exemplificados pelo autor, como segue: “[...] (1) a. as pessoa de la é muito bom. [Helvécia-M3] b. bota duas culeres n'agua morna[Helvécia-M2] (2) a. os ôtros disse [Monte Café-H3] b. issos coesa tudo [Monte Café-H3] [...]”" (Baxter 2009: 270).

\subsubsection{3 'Fontes'}

Os dados utilizados em "A concordância de número" foram obtidos junto a duas comunidades rurais de afrodescendentes: a comunidade de Helvécia (Bahia) e a comunidade dos tongas da roça Monte Café, na República de São Tomé e Príncipe, na África.

Para obter os dados da primeira comunidade, Baxter utilizou o estudo de Andrade (2003) e também os dados de uma pesquisa de campo complementar, realizada por ele mesmo, "[...] que incorpora dados de informantes adicionais gravados durante a mesma recolha que forneceu o corpus estudado por Andrade" (Baxter 2009: 271). Os dados se configuram da seguinte forma:

Andrade analisou dados de 18 informantes, equitativamente distribuídos em três faixas etárias e por gênero: faixa 1: de 21 a 40 anos; faixa 2: de 41 a 60 anos; faixa 3: de mais de 60 anos. Em contrapartida, a nossa reanálise contemplou quatro faixas etárias: faixa 1: de 21 a 40 anos; faixa 2: de 41 a 60 anos; faixa 3: de 61 a 80 anos; e faixa 4: de mais de 85 anos. Nesse caso, as 
faixas 1 a 3 continham 6 informantes cada uma, e a faixa 4 só tinha 3 informantes. O corpus dos tongas de Monte Café tem a mesma estrutura.

(Baxter 2009: 271)

Nos outros capítulos da obra, os dados foram retirados de amostras de fala provenientes de quatro comunidades rurais afro-brasileiras isoladas: Helvécia (município de Nova Viçosa), Cinzento (Município do Planalto), comunidades de Barra e Bananal (município de Rio de Contas) e Sapé (município de Valença). Essas comunidades foram selecionadas, pois são representativas nos seus contextos históricos e socioeconômicos. Elas têm origem associada ao cultivo de café e ao estabelecimento de engenhos de açúcar, agrupamento de escravos foragidos ou ao contexto da mineração. No total, são 48 entrevistas com moradores dessas quatro comunidades. Os dados de Baxter estão, pois, inseridos nessa iniciativa mais ampla de registro e descrição desses falares.

\subsubsection{4 'Técnica'}

Baxter submeteu os dados ao programa VARBRUL na versão GOLDVARB-X (SANKOFF; TAGLIAMONTE; SMITH, 2005) para analisar o fenômeno selecionado a partir de um conjunto de variáveis, a saber: "(i) saliência fônica do morfema PL; (ii) marcas de plural precedentes ao item em análise; (iii) configuração estrutural do sintagma nominal; (iv) gênero do falante; (v) faixa etária do falante” (Baxter 2009: 271).

De suas análises, Baxter conclui que há uma mudança geracional no fenômeno em questão, em que os mais jovens tendem a marcar mais PL nas comunidades do que os mais velhos. Outro resultado é que os homens também marcam mais do que as mulheres. Os fatores sociais responsáveis por isso são, segundo ele, escolarização e o fato dos homens saírem da comunidade mais que as mulheres.

Ainda com relação aos princípios metodológicos de análise, Baxter utiliza aportes tanto da Sociolinguística Variacionista como de perspectivas teóricas voltadas para a questão do contato de línguas e da aquisição de segunda língua, além da Gramática Gerativa. Estão entre suas referências Abney (1987), Picallo (1991) e Cinque (1994), Chomsky (2001b); especificamente sobre morfologia distribuída, menciona também Costa e Figueiredo Silva (2006). Baxter utiliza também o modelo não gerativista de Myers-Scotton e Jake (2000a, 2000b), o mesmo utilizado por Petter 
(2008). O autor utiliza muitos vieses teóricos para analisar a questão, ele justifica a inclusão de teorias relativas à aquisição de segunda língua, em virtude da condição das comunidades analisadas, cujas histórias apresentam o português como segunda língua.

\subsubsection{Síntese}

Podemos observar que a obra de Lucchesi, Baxter e Ribeiro (2009), em geral, e o artigo de Baxter, em particular, se inserem entre uma tendência descritivista e uma sociocultural. Há o tratamento de dados relativos à morfossintaxe e à sintaxe 'incidência de análise'. No entanto, a 'visão de língua' que fundamenta a análise é bastante sociocultural, tendo, inclusive, um tom político. A 'técnica' revela, justamente, a integração desses interesses socioculturais e descritivos na utilização de diferentes aportes teóricos e metodológicos como a Sociolinguística Variacionista, a Teoria Gerativa, a Teoria do Contato Linguístico e Estudos de Aquisição de Segunda Língua que permitem capturar a correlação entre variáveis linguísticas e extralinguísticas (ou socioculturais).

No próximo capítulo (Capítulo 6), apresentaremos os resultados das análises e a interpretação global dos dados a que chegamos. 


\section{Capítulo 6}

\section{PARA UMA HISTORIOGRAFIA DOS ESTUDOS DA RELAÇÃO DO PB COM LÍNGUAS AFRICANAS}

Tendo em vista os objetivos desta pesquisa, procuramos aqui retomar $e$ correlacionar alguns dos resultados de nossas análises, que foram apresentados, fundamentalmente, nos capítulos 3, 4 e 5. Acreditamos ter chegado a três resultados principais:

(1) do ponto de vista epi-historiográfico, reunimos uma bibliografia sobre o tema, oferecendo a ela, preliminarmente, uma análise panorâmica de tendências;

(2) do ponto de vista de uma historiografia descritivo/interpretativa, desenvolvemos uma análise de textos representativos da 'tradição' em foco, baseando-nos no conceito de 'programa de investigação' (e em seus formantes: 'visão', 'incidência' (esta, com destaque conferido às 'fontes') e 'técnica';

(3) ainda dessa perspectiva da descrição/interpretação, ensaiamos, no capítulo 3, a reunião de aspectos que permitem problematizar a divisão por fases da produção relativa às relações entre o $P B$ e as línguas africanas no contexto brasileiro proposta por Bonvini. Nesse capitulo, propusemos uma discussão e problematização orientados pela distribuição de conjuntos de textos por décadas ou períodos da história social do país e por uma análise panorâmica de temas e títulos.

Nas seções seguintes, discutimos esses resultados. 


\subsection{Bibliografia da produção brasileira sobre a relação do $P B$ com as línguas africanas (Epi-historiografia)}

Apresentamos no Capítulo 3 uma bibliografia acerca do tema do contato do PB com as línguas africanas produzida no Brasil. Esta primeira etapa de nossa dissertação consistiu-se a partir do levantamento, busca, tratamento e organização das fontes. De natureza 'epi-historiográfica', essa tarefa foi fundamental para as etapas seguintes de descrição e análise historiográfica a que nos propúnhamos, na medida em que nos ofereceu uma visão de conjunto sobre essa produção (seu volume, seus períodos de maior ou menor destaque, seus gêneros textuais mais destacados a cada período (livro, artigo, coletânea etc.), sua temática, suas opções em relação a enfoques teóricos e níveis linguísticos preferenciais, seus contextos gerais de produção e divulgação).

Foi o primeiro passo na constituição de uma crônica, pois, como sabemos, há poucas revisões históricas que se dedicaram à reunião, contextualização e ao tratamento da produção linguística sobre o tema.

Nossa impressão inicial de que a produção se avolumou e ficou em evidência mais recentemente foi confirmada pela expressiva quantidade de trabalhos que vieram a público nos últimos anos: em nosso mapeamento, há mais de 200 títulos concentrados na primeira década dos anos 2000.

Também é de se destacar que a produção sobre o tema é constante, apesar de no período de 1880 a 1919 haver poucos títulos; com efeito, considerados os nossos critérios de seleção, lidamos apenas com a produção de Macedo Soares em parte desse intervalo. Conforme explicamos no capítulo 3, é possível que nesse período estivessem sendo gestados os estudos que se publicam a partir de 1920. O mais comum, até pelo menos os anos 1950, era a elaboração de estudos mais amplos, no formato de livros, que provavelmente requeriam mais tempo para serem concluídos. Também é possível que algo do contexto dos estudos da língua portuguesa (como uma maior preocupação com o estabelecimento de normas de uso, por exemplo) tenha contribuído para isso. Finalmente, é razoável admitir, apesar de todos os esforços e cuidados de busca e de checagem de informações, que o levantamento tenha simplesmente falhado nesse ponto. Em vista dessa concorrência entre hipóteses, não arriscaremos comentário específico sobre essa escassez de textos publicados na virada do século XIX para o XX.

Verificamos, numa análise global dos temas e títulos, desde o século XIX até este começo de XXI, que há ampla preponderância de trabalhos dedicados ao exame do 
léxico, tendência que vai encontrar concorrência mais robusta apenas mais tardiamente nessa 'tradição', com a difusão de trabalhos com orientação estruturalista e, principalmente, gerativista - que colocam a morfossintaxe em destaque.

\subsection{Análise dos textos 'exemplares' da 'tradição' de estudos do contato do PB com línguas africanas (Historiografia Descritiva)}

Feita a atividade de documentação (estabelecida por uma 'epi-Historiografia'), passamos, nos capítulos 4 e 5, à historiografia descritiva/interpretativa, efetuando a análise de um corpus selecionado como 'exemplar' (observadas as tendências apontadas no capítulo 3). Destacamos aqui alguns aspectos relevantes de nossa análise.

\subsubsection{Perfil biográfico dos autores, constituição geral das obras e contextos de produção e circulação de conhecimento}

Sobre o perfil biográfico dos autores, podemos destacar que os estudiosos sobre o tema se tornaram cada vez mais especializados, acompanhando a tendência geral da área de Letras e Linguística no Brasil. De homens "comuns", simplesmente interessados no tema, a partir da fundação dos cursos de Letras - nos anos 1930 - passam a ser especialistas, que, a cada novo período, exibem uma visão mais treinada e pontual sobre os objetos investigados.

Do primeiro grupo de autores aqui analisados - Macedo Soares (1942[18741890]), Mendonça (1933), Raimundo (1935[1933]), e Silva Neto (1950) -, somente Silva Neto pôde desfrutar de um contexto de circulação de ideias mais marcado pela especialização, exercendo a função de professor e pesquisador universitário.

Já no segundo grupo que formamos para as análises, não há apenas "interessados" no tema; ele é composto por investigadores como Naro, Scherre, Petter, Pessoa de Castro, Baxter, Lucchesi e Ribeiro, todos pesquisadores longamente treinados em relação aos avanços teóricos e metodológicos da Linguística contemporânea. São pesquisadores que se tornaram, ao longo de muitos anos de tratamento do tema, autoresreferência na área, com produção de forte impacto; são, ademais, pesquisadores que contribuem para a formação de novas gerações de investigadores, garantindo, com isso, certa continuidade dos tipos de abordagem que implementaram e contribuindo para a vivacidade do tema na área de Letras e Linguística. 
Com relação à constituição das obras de maneira geral e às suas formas de circulação, observamos uma mudança de preferência dos meios de publicação: de livros (de um autor e com visadas amplas) para: a) artigos, às vezes resultantes de apresentações em eventos; b) teses e dissertações; c) livros organizados, que reúnem capítulos elaborados por diferentes pesquisadores, fato que também está em consonância com as transformações dos contextos de produção e circulação de conhecimento, como procuramos apontar no capítulo 5. Nesse sentido, torna-se, no segundo macro-período aqui estudado, mais rara a circulação de obras de pretensão analítica mais abrangente, como as dos autores do primeiro grupo analisado; os textos contemporâneos, como pudemos observar, tendem a ter temática mais circunscrita e orientação teórica mais específica (e mais claramente definida).

\subsection{2 'Horizonte de retrospecção'}

Múltiplos são os diálogos, convergentes e divergentes, estabelecidos pelos autores dos dois grupos com outros estudiosos e com outros textos, sejam da subárea do contato linguístico, sejam das diferentes escolas da Linguística, sejam de áreas correlatas (como a História, a Etnografia, a Antropologia, a Sociologia). De fato, a complexidade do tema leva todos autores examinados, em maior ou em menor medida, a mobilizar uma rede diversificada de informações.

Ademais, está também presente em todos os autores selecionados a queixa acerca da carência de dados, tanto linguísticos quanto sobre os falantes e seus contextos. A questão das 'fontes' passa, assim, a figurar como um problema admitido (e evidentemente dividido com os estudos que se realizam em outras áreas, dadas as profundas lacunas que cercam o conhecimento sobre os africanos e seus primeiros descendentes no Brasil).

No primeiro grupo de autores analisados, verificamos um outro traço comum, presente em maior ou menor grau: a forma difusa e imprecisa de fazer referências bibliográficas, que gera a dificuldade de identificação de autores e obras referidos. Nesse caso, Macedo Soares parece ser o exemplo mais emblemático: as informações estão incompletas e excessivamente abreviadas, traço mais ou menos comum até meados do século XX. Como afirmamos no Capítulo 4, supomos que essa característica possa estar relacionada à relação autor/público-leitor visado; tal leitor seria, em tese, conhecedor das referências relevantes, que não eram ainda tão abundantes; um leitor 
que não necessitaria de tantos detalhamentos para identificar o ainda parco conjunto de textos em circulação na especialidade em formação no Brasil.

Vimos que Silva Neto menciona os trabalhos de Macedo Soares, Mendonça e Raimundo. Somente este último desfruta de algum reconhecimento: Silva Neto julga pertinentes as análises que Raimundo realiza da fala do negro a partir dos trabalhos de Gil Vicente. Quanto aos demais autores, verificamos discordância ou reprovação, seja nas considerações feitas sobre o PB, de maneira geral, seja naquelas mais específicas, sobre a relação com as línguas africanas.

O conceito de 'horizonte de retrospecção' se revelou útil em nossa análise, na medida em que permitiu confirmar sua relação com os 'programas de investigação' desenvolvidos. Por exemplo, nesse diálogo convergente de Silva Neto com Raimundo, vislumbra-se uma aproximação de perspectiva entre investigadores cujos trabalhos foram publicados com um intervalo cronológico considerável; por outro lado, a divergência entre os 'horizontes de retrospecção' dos contemporâneos Mendonça e Raimundo, demonstrada no capítulo 4, indica uma diferenciação fundamental entre seus textos, tidos em diferentes revisões históricas como semelhantes. Os dois autores falam a partir de perspectivas muito distintas, como vimos.

Nos textos mais recentes, mesmo quando é possível observar uma rede de referências comuns, é notável a diversidade nos modos de utilizá-las. Entre essas referências comuns, estão os textos dos autores do grupo anterior, tornados, ao longo da história, espécies de "clássicos" da área. Petter, como vimos, é quem realiza uma retrospectiva que consideramos a mais abrangente entre as avaliadas: todos os demais autores que selecionamos, anteriores ou contemporâneos a ela, são mencionados na sua tese de livre-docência. É possível que a natureza do trabalho tenha imposto uma revisão mais ampla e detalhada do que as possíveis de se realizar em artigos e coletâneas de textos organizadas (formatos assumidos pelos demais textos dessa segunda fase que analisamos).

Entre Naro \& Scherre, de um lado, e Lucchesi, Baxter e Ribeiro, de outro lado, instaura-se uma retórica de ruptura bastante explícita. Divisam-se duas interpretações conflitantes nesse cenário de reflexões contemporâneo. Comparativamente, Petter adota um tom conciliador, ao considerá-las, ambas, perspectivas legítimas, ainda que discorde da de Lucchesi, Baxter e Ribeiro.

\subsection{3 'Programa de investigação'}


Destacamos aqui alguns resultados referentes ao ‘programa de investigação’ em que se inserem os textos. Tal conceito, como vimos no Capítulo 1, organiza-se em torno de três parâmetros: 'visão de língua', 'incidência da análise' e 'técnica'.

Conforme discutiremos na próxima seção, consideramos mais adequado não categorizar os trabalhos rigidamente em 'programas de investigação', mas, sim, procurar destacar os traços predominantes nos textos selecionados. Por exemplo, o tratamento formal de dados, guardadas as devidas proporções entre diferentes modelos teóricos e metodológicos (mais ou menos explícitos, mais ou menos apreendidos ou “incorporados" pelos diferentes atores a cada período e a cada contexto), é comum a todos, em virtude da própria natureza do tema, o que não justifica a inclusão de todos os trabalhos no 'programa de investigação descritivista'.

O conceito de 'programa de investigação' foi responsável por nos guiar em nossas análises e reflexões sem, no entanto, engessar nossa perspectiva. Em outras palavras, não tivemos como motivação propor uma classificação, mas buscar compreender os textos selecionados inclusive em seu eventual ecletismo. Nesse sentido, aparando as especificidades, pudemos verificar duas tendências preponderantes, uma mais descritivista e outra mais sociocultural, que sempre se mesclam em algum nível, mas que parecem se alternar, em termos de preponderância nas diferentes obras.

Assim, no primeiro grupo, Raimundo apresenta tendência mais descritivista; Macedo Soares, Mendonça e Silva Neto parecem inclinar-se mais à orientação sociocultural. Quanto ao segundo grupo, é possível dizer que se apresentam como híbridos, tanto descritivistas quanto socioculturalistas, Naro \& Scherre, Lucchesi, Baxter e Ribeiro, Petter e Castro; somente nesta última pudemos identificar com maior clareza o predomínio da tendência sociocultural ${ }^{1}$. Sem nos atermos a detalhes apresentados nos Capítulos 4 e 5, vamos aos nossos resultados gerais:

\subsubsection{1 'Visão de língua'}

Quanto a esse parâmetro, observamos que todos os autores reconhecem a natureza complexa do objeto em estudo, que tem aspectos sociais, históricos, antropológicos constitutivos; no entanto, como já observamos, varia o nível de

\footnotetext{
${ }^{1}$ Mais adiante, apresentaremos nossa proposta de periodização para essas tendências.
} 
integração dessa premissa às análises linguísticas realizadas. Autores como Mendonça, Macedo Soares e Pessoa de Castro colocam os elementos extralinguísticos como mais centrais na descrição dos fenômenos linguísticos em análise. Nos demais textos analisados, esses elementos, igualmente mobilizados, parecem funcionar como contextualizadores das descrições linguísticas.

\subsubsection{2 'Incidência de análise'}

Nos trabalhos de Macedo Soares, Petter e Pessoa de Castro, observamos um destaque para o tratamento do léxico. Nesse grupo, Petter se diferencia dos demais, pois sua abordagem é relativa a uma teoria da gramática de base lexicalista. Já em Mendonça, Raimundo, Silva Neto - como vimos, obras correspondentes a visadas de pretensão mais abrangente sobre o tema -, são contemplados todos os níveis de descrição: fonético, lexical, morfológico e sintático, ainda que nos dois primeiros autores também haja destaque para o léxico. Já em Naro \& Scherre e em Lucchesi, Baxter e Ribeiro, privilegia-se a análise de dados morfossintáticos e sintáticos, sem referência especial às unidades lexicais.

Também é de se destacar, quanto à 'incidência', que a "descoberta da África" no Brasil e o interesse - apenas declarado ou efetivado - pelo contexto africano e pelas outras variedades do Português, que não o $\mathrm{PB}$ e $\mathrm{o}$ PE, são importantíssimos desenvolvimentos da área, alcançados apenas a partir do último quartel do século XX. Com efeito, essas alterações no foco são capazes de revolucionar a área, na medida em que, potencialmente, amenizam problemas reais e persistentes, como o de escassez de ‘fontes' de dados para análise (linguística ou extralinguística).

\subsubsection{3 'Fontes'}

Relevada a questão persistente de efetiva escassez de dados, cumpre observar que, no primeiro grupo, de maneira geral, predomina a apresentação dos dados sem a identificação de 'fonte'. Já nos trabalhos contemporâneos, observamos o uso de 'fontes' de origens bastante diversificadas, incrementadas a partir do momento em que se começa a considerar os aspectos mencionados no item anterior - aspectos esses que, inclusive, tornam recomendável a realização de trabalhos de campo. As 'fontes' tendem, nesse segundo momento, a ser claramente identificadas. 


\subsubsection{1 'Técnica'}

Como afirmamos antes, ao lado dos textos de visada abrangente, que perpassam diferentes níveis de análise linguística, quanto à metodologia empregada, observamos que há, nos outros textos, dois eixos centrais: aquele que se centra na seleção e no exame de dados de natureza léxico-semântica, e aquele que privilegia o exame de fenômenos morfossintáticos. As análises léxico-semânticas em geral privilegiam o roteiro característico do 'programa descritivista': determinação de contextos, segmentação, comutação, estudo das relações de proporcionalidade entre os elementos e, eventualmente, estabelecimento de relação entre as formas linguísticas e funções comunicativas. Nos estudos que privilegiam a análise sintática e morfossintática, ocorre a inserção de fatos linguísticos em uma análise das sociedades ou das culturas, ou em uma teoria da estratificação social ou da evolução linguístico-social, que caracterizam o 'programa sociocultural' (esta última tendência apoiada nos desenvolvimentos da Sociolinguística e nos estudos de mudança paramétrica). No entanto, tal como afirmamos em 6.2.3, essas tendências parecem se mesclar em propostas híbridas ou ecléticas, que assimilam traços dos dois 'programas'.

\subsection{Proposta preliminar de periodização para os estudos da relação do $\mathrm{PB}$ com línguas africanas}

Neste ponto do trabalho, acreditamos que podemos lidar com algumas de nossas motivações iniciais, provocadas pelo artigo de Bonvini (2009).

Conforme apresentamos no Capítulo 1, o autor propõe que existam duas fases na tradição brasileira de estudos sobre o tema: a da 'influência' e da 'crioulização'. Desejamos propor que, ainda que o tratamento da relação do PB com as línguas africanas em termos de 'influência' seja preponderante entre as décadas de 1800 a 1950 (e não somente até a década de 30, como defende o autor), ele é persistente até as últimas décadas contempladas neste nosso estudo. Também o tratamento da questão em termos de 'crioulização', mais explicitamente formulado, no contexto brasileiro, na obra de Silva Neto aqui analisada, parece ter certa continuidade com outras formulações no conceito de 'transmissão linguística irregular', e faz-se presente, até hoje, nos trabalhos de Lucchesi, Baxter e Ribeiro. Verificamos, portanto, na história desta produção, mais 
'continuidades' do que 'rupturas'; 'influência' e 'crioulização' seguem como perspectivas de análise à disposição dos pesquisadores no contexto mais contemporâneo. Nas últimas décadas, essas perspectivas apresentam-se ladeadas, talvez até suplantadas, pela perspectiva instaurada pelos estudos do 'contato'. Esta última perspectiva, aparentemente mais neutra, parece ter adquirido maior visibilidade no contexto atual de produção.

Cabe assinalar, ainda, que enxergar a área por meio dessa dicotomia 'influência' e 'crioulização', ou, por outro lado, imaginar a perspectiva dos estudos de 'contato' como um foco de convergência inexorável dos estudos da área parece reduzir a pluralidade teórica e metodológica que ela encerra, sobretudo quando consideramos as últimas décadas do período aqui considerado. Como dissemos, a bibliografia assinala a emergência de abordagens mais especializadas e mais pontuais, voltadas para temas de interesse da Linguística geral e de subáreas particulares desse campo do conhecimento; temos, assim, trabalhos situados nos domínios da fonética, da descrição gramatical, lexical, textual e discursiva, em que ganham força novos vieses diacrônicos, o viés sociolinguístico etc.

Quanto à crítica referente à metodologia empregada nos estudos, que, para Bonvini (2009), se caracteriza pela seleção preponderante de dados de natureza léxicosemântica, em um período, e morfossintática, em outro, nós verificamos, de fato, que esses dois recortes funcionam como eixos principais no modo de aproximação dos dados. Há uma análise mais lexical ligada aos trabalhos de tendência mais sociocultural e outra de análise mais sintática e morfossintática, ligada a trabalhos de tendência mais híbrida entre o descritivista e sociocultural.

Essas perspectivas concorrem e co-ocorrem ao longo dos séculos XX e XXI, embora recentemente um maior número de investigações tenha se debruçado sobre os aspectos sintáticos e morfossintáticos na língua em suas relações com as línguas africanas.

Podemos representar essas tendências do seguinte modo:

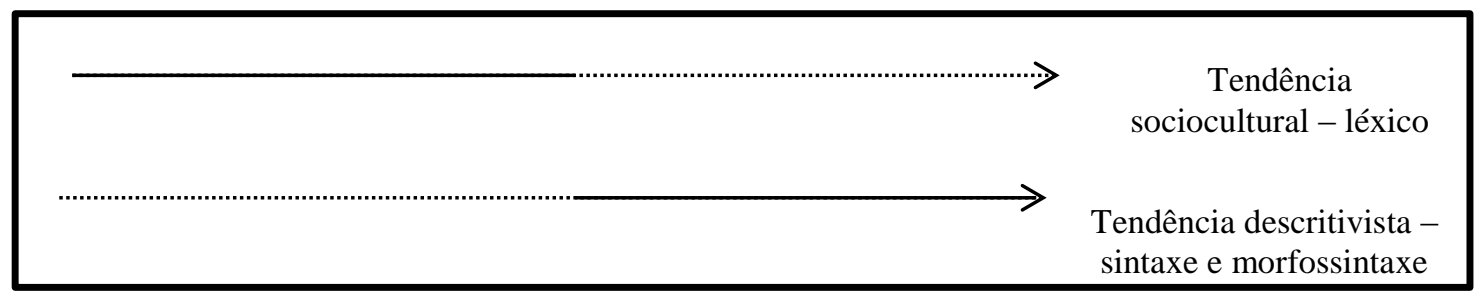

Figura 01: Representação das tendências 
$\mathrm{Na}$ representação acima, procuramos assinalar que as duas tendências ocorrem em todo o período (linhas paralelas); ao lado das 'rupturas', há 'continuidades' significativas (as linhas estão tracejadas assinalando que a 'continuidade' é mais insistência em determinados traços do que mera continuação de propostas nas diferentes gerações de estudiosos). Além disso, demonstramos, com o negrito, que, em diferentes momentos, uma das tendências desfruta de maior visibilidade no contexto brasileiro do que outra.

De fato, segundo Koerner (1989), que se inspira em Dell Hymes, a Linguística tende a seguir esse modelo de desenvolvimento histórico em que há correntes centrais e correntes periféricas disputando o prestígio e a visibilidade no campo de estudos ao longo de sua história. Esse modelo prevê a co-ocorrência de correntes igualmente inseridas num determinado contexto de produção e circulação de saberes, mas desfrutando diferentes graus de prestígio: assim, há sempre, em uma comunidade científica, a cada período, mainstream (dominantes) e underground (marginais) currents (correntes dominantes e marginais), compondo um cenário científico compartilhado.

Conforme verificamos na Figura 01, a tendência sociocultural, em um primeiro momento, esteve no centro da discussão sobre o tema na área; entretanto, mais recentemente, a tendência descritivista assumiu papel de maior destaque.

Há outros modelos disponíveis em Historiografia Linguística no próprio texto de Koerner (1989); todavia, na reflexão desenvolvida ao longo desta dissertação, acreditamos que este modelo tenha maior poder explicativo. 


\title{
Considerações finais
}

\begin{abstract}
O que se pode perceber é que o investimento na pesquisa sobre os remanescentes culturais africanos no Brasil acaba por delinear com maior clareza nosso ainda grande desconhecimento sobre a contribuição afronegra à formação da cultura brasileira e, ao mesmo tempo, a enorme força e alcance dessa contribuição. Eu diria, portanto, que, neste campo de estudos, estamos ainda começando. Mais do que nunca, vivemos um momento de chamada à pesquisa sobre o tema fascinante da pluralidade cultural no Brasil (Queiroz 2002: 56)
\end{abstract}

Esta pesquisa investigou a tradição de estudos da relação do PB com línguas africanas produzidos no Brasil, do século XIX ao XXI. Tratamos, sobretudo, da 'metodologia' estabelecida e do uso feito das 'fontes', aspectos tidos como controversos na literatura que anteriormente reviu essa produção. Propusemos uma bibliografia básica aos pesquisadores interessados no tema, bem como ao público em geral que queira conhecer parte da história dessa tradição consolidada e proficua na área de estudos da linguagem no país. Também sugerimos uma forma de se repensar a periodização disponível para essa história, sem lidar rigidamente com fases homogêneas, mas admitindo a convivência entre perspectivas variadas, que, nas diferentes épocas, têm desfrutado de distintos graus de prestígio no contexto brasileiro de produção e circulação de conhecimentos. Para propor essa problematização da periodização, avaliamos dados tanto da nossa análise de 'exemplares' selecionados, quanto da análise panorâmica de nossa bibliografia geral.

O conceito de 'programa de investigação' foi bastante útil como guia para nossas análises, ao permitir investigar mais a fundo nosso objeto, nos vários aspectos que compõem uma 'metodologia' de pesquisa em Linguística; cremos que ele de fato nos possibilitou depreender características essenciais dos heterogêneos textos que constroem essa tradição. Aplicamos esse conceito de forma pouco rígida, sem a intenção de "classificar" os textos nas quatro categorias estabelecidas por Swiggers (2004). Nossa intenção, ao contrário, era colocar os textos em evidência, nos valendo da proposta de Swiggers como forma controlada de aproximação. Em vista desse emprego do modelo historiográfico, pudemos reconhecer, por exemplo, que todas as 
pesquisas aqui analisadas realizam algum tratamento formalizado de dados linguísticos, guiado por um modelo explícito de descrição; isto é, todas elas se caracterizam, em maior ou menor grau, como 'descritivistas'. Além disso, o objeto de estudo em análise é naturalmente transdisciplinar, o que requer, também de forma mais ou menos intensa e com maior ou menor relevância explicativa, um tratamento de natureza 'sociocultural' da questão linguística.

Ao concluir esta jornada, avaliamos que nosso trabalho pode contribuir para área da Historiografia Linguística, para os de Estudos de contato do PB com as línguas africanas, bem como para a própria História do PB em alguns aspectos: reunimos estudos realizados sobre o tema em um extenso período de tempo e refletimos, a partir de modelo oferecido pela Historiografia Linguística; avaliamos os modos de tratar esse tema, buscando contribuir para a construção de um percurso histórico um pouco mais detalhado para essa tradição.

Diante de tão ousada e complexa empreitada (ousadia e complexidade da qual apenas recentemente nos demos conta!) e também por causa da extensão de uma dissertação de mestrado e dos limites de tempo de que dispúnhamos, realizamos um exame de 'exemplares' selecionados que consiste em uma primeira aproximação, a ser "revista e ampliada" em outros trabalhos. Também é possível que a bibliografia apresente alguma lacuna significativa, já que se consolidou a partir de um processo de busca e seleção de textos publicados em três séculos, processo esse realizado no âmbito de uma pesquisa individual.

Entretanto, esta é uma iniciativa, modesta, que pretende se alinhar a outras tomadas no país no sentido de se compreender e se divulgar 'o tema fascinante da pluralidade cultural e linguística no Brasil'. 


\section{Referências Bibliográficas}

ABNEY, Steven Paul. The English noun phrase in its sentential aspect. Cambridge: Massachusetts Institute of Technology, 1987.

AGUILERA, Sandra Mara. A influência africana na língua portuguesa. In: LIMA, Ivan Costa; ROMÃO, Jeruse; SILVEIRA, Sônia Maria (Org.). Os negros, os conteúdos escolares e a diversidade cultural. Florianópolis: Núcleo de Estudos Negros (NEN), 1998, v. 3, p. 15-29. (Série Pensamento Negro em Educação).

ALCÂNTARA, Edson Mário de. O negro e a linguagem: influências do negro na formação da língua no Brasil. Scientia ad Sapientiam, Maceió, v. 1, n. 2, p. 71-4, dez. 1978.

ALKMIM, Tânia Maria. A classe 'difícil' de predicados ajdetivais em português. Campinas, 1975. Mestrado (Dissertação em Linguística) - Universidade Estadual de Campinas.

ALKMIM, Tânia Maria. Les 'Portugais'de Zinguinchor (Senegal). França, 1984. Doutorado (Tese em Linguística) - Université Paris Descartes.

ALKMIM, Tânia Maria. Linguagem de escravos: estudo de um caso de representação. Leitura: Teoria e Prática, Campinas, v. 25, p. 42-46-, 1995.

ALKMIM, Tânia Maria. Linguagem de escravos: em busca de registros históricos. Estudos Portugueses e Africanos, Campinas, v. 28, p. 63-71, 1996.

ALKMIM, Tânia Maria. Português de negros e escravos: atitudes e preconceitos históricos. Estudos Portugueses e Africanos, Campinas, v. 31, p. 39-47, 1998.

ALKMIM, Tânia Maria. Estereótipos linguísticos: negros em charges do século XIX. In: ALKMIM, Tania Maria. (Org.). Para a História do Português Brasileiro: Volume III. São Paulo: Humanitas, 2002, v. 3, p. 383-402. 
ALKMIM, Tânia Maria. Fala de escravos brasileiros e portugueses: um esboço de comparação. In: LOBO, Tânia; RIBEIRO, Ilza; CARNEIRO, Zenaide; ALMEIDA, Norma (Org.). Para a história do português brasileiro: Volume IV: Novos dados, novas análises. Salvador / BA: EDUFBA, 2006, v. II, p. 585-594.

ALKMIM, Tânia Maria. A fala como marca: escravos nos anúncios de Gilberto Freire. Scripta (PUCMG), v. 9, p. 221-229, 2006.

ALKMIM, Tânia Maria. Falas e cores: um estudo sobre o português de negros e escravos no Brasil do século XIX. In: CARMO, Laura do; LIMA, Ivana Stolze. (Org.). História social da língua nacional. Rio de Janeiro: Casa de Rui Barbosa, 2008, p. 247264. Disponível

em http://www.coresmarcasefalas.pro.br/adm/anexos/11122008002308.pdf Acesso em: 31/10/2013.

ALKMIM, Tânia Maria; PETTER, Margarida Maria Taddoni. Palavras da África no Brasil de ontem e de hoje. In: FIORIN, José Luiz; PETTER, Margarida Maria Taddoni. (Org.). África no Brasil: a formação da língua portuguesa. São Paulo: Contexto, 2008, p. $145-179$.

ALKMIM, Tânia Maria; LOPEZ, Laura Álvarez. Registros da escravidão: as falas de pretos-velhos e de Pai João. Stockholm Review of Latin American Studies, v. 4, p. 3748, 2009.

ALKMIM, Tânia Maria. Itinerários linguísticos de africanos e seus descendentes no Brasil do século XIX. In: CARVALHO, Ana Maria (Org.). Português em contato. Madri: Iberoamericana, 2009, v. 2, p. 177-197.

ALKMIM, Tânia Maria. A variedade linguística de negros e escravos: um tópico da história do português no Brasil. In: MATTOS E SILVA, Rosa Virginia. (Org.). Para história do português brasileiro: Volume II. São Paulo: Humanitas/FFCH-USP, 2001, v. 2 , p. 317-335.

ALMEIDA, Alessandra Preussler. A concordância verbal na comunidade de São Miguel dos Pretos, Restinga Seca, RS. Porto Alegre, 2005. Dissertação (Mestrado em Estudos da Linguagem) - Instituto de Letras, Universidade Federal do Rio Grande do Sul. 
ALMEIDA, Norma Lucia Fernandes de. Sujeito nulo e morfologia verbal no português falado por três comunidades do interior da Bahia. Campinas, 2005. Tese (Doutorado em Linguística) - Instituto de Estudos da Linguagem, Universidade Estadual de Campinas.

ALMEIDA, Norma Lucia Fernandes de; CARNEIRO, Zenaide Oliveira Novais. Sujeito. In: LOBO, Tânia; OLIVEIRA, Klebson. (Org.). África à Vista. Salvador: EDUFBA, 2009, p. 70-89.

ALTMAN, Cristina; COELHO, Olga. Documenta Grammaticae et Historiae: projeto de documentação linguística e historiográfica (séculos XVI-XIX). São Paulo, CEDOCH - DL USP. (site: www.fflch.usp.br/dl/documenta).

ALTMAN, Cristina. A pesquisa lingüística no Brasil (1968-1988). São Paulo: Humanitas, 2004

ALVES, Henrique L. Bibliografia afro-brasileira: estudos sobre o negro. $2^{\mathrm{a}}$ ed. revista e ampliada. Rio de Janeiro/Brasília: Cátedra/INL, 1979

AMARAL, Amadeu. O dialeto caipira. São Paulo: Casa editora “O Livro”, 1920.

ANDRADE FILHO, Sílvio Vieira de. Um estudo sociolinguístico da comunidade negra do Cafundó. São Paulo, 1993. Tese (Doutorado em Linguística) - Faculdade de Filosofia, Letras e Ciências Humanas, Universidade de São Paulo.

ANDRADE FILHO, Sílvio Vieira de. Um estudo sociolingüístico das comunidades negras do Cafundó, Caxambu e de seus arredores. Sorocaba: Prefeitura Municipal, Secretaria da Educação e Cultura de Sorocaba, 2000.

ANDRADE, Karylleila dos Santos; ESTEVES, Francisco; LIMA, Sibéria Salles Queiroz de. Perfil sociolinguístico e socioeconômico das comunidades remanescentes de quilombolas do estado do Tocantins: considerações iniciais. Revista Entre Letras: Revista do Curso de Mestrado em Ensino de Língua e Literatura da Universidade Federal do Tocantins (UFT), Araguaína, v. 1, nº 1, p. 91-117, II semestre, 2010.

ANDRADE, Patrícia Ribeiro de. A concordância nominal de número no português afrobrasileiro. Revista do GELNE (UFC), João Pessoa, p. 2075-2082, 2004. 
ANDRADE, Patrícia Ribeiro de. Um fragmento da constituição sócio-histórica do português do Brasil: variação na concordância nominal de número em um dialeto afrobrasileiro. Salvador, 2003. Dissertação (Mestrado em Linguística) - Instituto de Letras, Universidade Federal da Bahia, Salvador.

APONTES, Selmo Azevedo Pontes. Bundinzando as palavras portuguesas: lenço e rilenzo, lenços e malénzo, um breve olhar sobre a acomodação da prefixação banto em Cannecattim (1805). Suplemento da Revista Philologus, Ano 17, N ${ }^{\circ}$ 49, 2011. Disponível em http://www.filologia.org.br/v_jnlflp/08.pdf Acesso em 01.12.2014.

ARAGÃO, Maria do Socorro Silva. A presença africana nos falares nordestinos. Confluência, Rio de Janeiro: Instituto de Língua Portuguesa, $\mathrm{n}^{\circ} 12$, p. 87-100, $2^{\circ}$ semestre de 1996.

ARAUJO, Edinalva. As construções de tópico. In: LUCCHESI; Dante; BAXTER, Alan; RIBEIRO, Ilza. (Org.). O Português Afro-Brasileiro. $1^{\mathrm{a}}$ ed. Salvador: EDUFBA, 2009 , v. 1, p. 231-250.

ARAUJO, Edinalva. Tópico. In: LOBO, Tânia; OLIVEIRA, Klebson (Orgs). África à vista: dez estudos sobre o português escrito por africanos no Brasil do século XIX. Salvador: EDUFBA, 2009, p. 50-69.

ARAÚJO, Paulo Jeferson Pilar. Alternância no uso das preposições "para" e "em" na fala de comunidades quilombolas: análise sob a perspectiva da Linguística Cognitiva. Estudos Linguísticos (São Paulo), v. 38, p. 335-346, 2009.

ARAÚJO, Paulo Jeferson Pilar. Aspectos semântico-cognitivos de usos espaciais das preposições "para" e "em" na fala de comunidades quilombolas. São Paulo, 2009. Dissertação (Mestrado em Linguística) - Faculdade de Filosofia, Letras e Ciências Humanas, Universidade de São Paulo.

ARAUJO, Silvana Silva de Farias; ARAUJO, Jean Marcel de Oliveira. A formação sócio-histórica do português do Brasil: contribuições do recôncavo baiano. Disponível em http://www.cadernosdeletras.uff.br/anteriores/images/stories/edicoes/39/artigo5.pdf Acesso em 21/09/2013. Cadernos de Letras da UFF - Dossiê: Difusão da língua

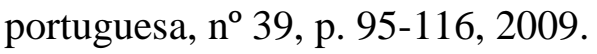


AUROUX, Silvain. 1992. A revolução tecnológica da gramatização. Campinas: Editora da Unicamp.

AVELAR, Juanito Ornelas; CYRINO, Sônia. Locativos preposicionados em posição de sujeito: uma possível contribuição das línguas Bantu à sintaxe do português brasileiro. Revista de Estudos Linguísticos da Universidade do Porto, Porto, v.3, p. 54-75, 2008.

AVELAR, Juanito Ornelas; CYRINO, Sônia. Locativos em posição de sujeito: línguas bantas e português brasileiro. In: TORRES MORAIS, Maria Aparecida; ANDRADE, Maria Lúcia da Cunha Victório de Oliveira. (Org.). História do Português Paulista. Campinas: Publiel/Fapesp, 2009, v. II, p. 218-249.

AVELAR, Juanito Ornelas; CYRINO, Sônia; GALVES, Charlotte. Locative Inversion and Agreement Patterns: Parallelisms between Brazilian Portuguese and Bantu Languages. In: PETTER, Margarida; MENDES, Ronald. (Org.). Exploring the African Language Connection in the Americas - Proceedings of the Special Word Congress of African Linguistics (2008). São Paulo: Humanitas, 2009, v. 1, p. 207-221.

BALLY, Charles. 1921[1909]. Traité de Stylistique française. Paris: Klincksieck.

BARANOW, Ulf G. 1990. Bibliografia indexada de Dissertações e Teses em Letras e Linguística defendidas em Universidades brasileiras. Linguística. V. I. ANPOLL.

BARBOSA, Waldemar de Almeida. Negros e quilombos em Minas Gerais. Belo Horizonte: [Imprensa Oficial], 1972.

BARRETO, Therezinha. Articulações de orações e emprego de conectores interfrásticos. In: LOBO, Tânia; OLIVEIRA, Klebson (Orgs). África à vista: dez estudos sobre o português escrito por africanos no Brasil do século XIX. Salvador: EDUFBA, 2009, p. 241-254.

BATINGA, Gastão. Aspectos da presença do negro no Triângulo Mineiro/Alto Paranaíba: Kalunga. Uberlândia: Ed. do autor, 1994.

BAXTER, Alan Norman; LUCCHESI, Dante. A relevância dos processos de pidgnização e crioulização na formação da língua portuguesa no Brasil. Estudos Lingüísticos e literários, Salvador, nº 19, pp. 65-84, set.1997. 
BAXTER, Alan. A Grammar of Kristang (Malacca Creole Portuguese). Austrália, 1985. Tese (Doutorado em Linguística) - Australian National University.

BAXTER, Alan. El Modo Subjuntivo en los Complementos Oracionales en Español. Austrália, 1978. Dissertação (Mestrado em Linguística Hispânica) - La Trobe University, Austrália.

BAXTER, Alan; LUCCHESI, Dante. Processos de descrioulização no sistema verbal de um dialeto rural brasileiro. Papiá - Revista de Crioulos de Base Ibérica, Brasília, Universidade de Brasília, v.2, n.2, p. 59-71, 1993.

BAXTER, Alan; LUCCHESI, Dante; GUIMARÃES, Maximiliano. Gender agreement as a decreolizing feature of the Afro-Brazilian rural dialect of Helvécia. Journal of Pidgin and Creole Languages, Filadélfia/Amsterdam, v.12, n.1, p.1-57, 1997.

BAXTER, Alan; LUCCHESI, Dante. Un paso más hacia la definición del pasado criollo del dialecto afro-brasileño de Helvécia (Bahia). In: ZIMMERMANN, Klaus (Ed.). Lenguas criollas de base lexical española y portuguesa. Madri: Iberoamericana, 1999, p.119-141.

BAXTER, Alan; LOPES, Norma. Bare definite reference NPs in an Afro-Brazilian Portuguese dialect. Revista Internacional de Lingüística Iberoamericana, Madrid, v.4, n.1, p.55-70, 2006.

BAXTER, Alan. A concordância de número. In: LUCCHESI; Dante; BAXTER, Alan; RIBEIRO, Ilza. (Org.). O Português Afro-Brasileiro. $1^{a}$ ed. Salvador: EDUFBA, 2009, v. 1, p. 269-294.

BAXTER, Alan. Concordância Verbal. In: LOBO, Tânia; OLIVEIRA, Klebson (Orgs). África à vista: dez estudos sobre o português escrito por africanos no Brasil do século XIX. Salvador: EDUFBA, 2009, p. 317-337.

BAXTER, Alan; LOPES, Norma. O artigo definido. In: LUCCHESI, Dante; BAXTER, Alan; RIBEIRO, Ilza. (Org.). O Português Afro-Brasileiro. $1^{\mathrm{a}}$ ed.Salvador: EDUFBA, 2009, v. 01, p. 319-330. 
BITTENCOURT, Regina Lúcia. Apagamento dos pronomes clíticos de forma reflexiva. In: LOBO, Tânia; OLIVEIRA, Klebson (Orgs). África à vista: dez estudos sobre o português escrito por africanos no Brasil do século XIX. Salvador: EDUFBA, 2009, p. 90-137.

BLANCHE-BENVENISTE, C. Langue parlée et langue écrite: décalages en morphologie et en syntaxe. In: MOURA, D. (org.) Os múltiplos usos da língua. Maceió: Edufal, 1999, pp. 16-25.

BONVINI, Emilio. "Línguas africanas e português falado no Brasil”. In: FIORIN, José Luiz; PETTER, Margarida Maria Taddoni (Orgs.). África no Brasil: a formação da língua portuguesa. São Paulo: Contexto, 2009, p. 15-62.

BONVINI, Emilio; PETTER, Margarida Maria Taddoni. Portugais du Brésil et langues africaines. Langages. Paris, n. 130, 1998, p. 68-83.

BORBA, Francisco S.. Dicionário de usos do português do Brasil. São Paulo: Ed. Ática, 2002.

BORGES, Patrícia. Linguagem-objeto e metalinguagem. Estudo historiográfico sobre tradição e ruptura em Dias (1697). Relatório de Iniciação Científica. CEDOCH/DLUSP/FAPESP. 2011. Orientadora: Olga Coelho.

BORGES, Patrícia. O tratamento da metalinguagem referente às "partes do discurso" nas gramáticas de Pedro Dias (1697) e Mamiani (1699). Relatório de Iniciação Científica. CEDOCH/DL-USP/CNPq. 2010. Orientadora: Olga Coelho.

BORGES, Patrícia. Metalinguagem e descrição de línguas ágrafas no Brasil do século XVII - As gramáticas de Pedro Dias (1697) e Mamiani (1699). Relatório de Iniciação Científica. CEDOCH/DL-USP/CNPq. 2009. Orientadora: Olga Coelho.

BUENO, Francisco da Silveira. "Influencia das línguas africanas no português do Brasil”. Jornal de Filologia, Lisboa, vol. 2, fasc. 3, pp. 217-31, 1954.

BUENO, Francisco da Silveira. A formação histórica da língua portuguesa. Rio de Janeiro: Livraria Acadêmica, 1955. 
BUENO, Francisco da Silveira. Estudos de Filologia portuguesa. São Paulo: Saraiva 1954.

BURGOS, Luiz Eduardo Simões de. Estratégias de uso das relativas em uma comunidade de fala afro-brasileira. Salvador, 2003. Dissertação (Mestrado em Letras e Linguística) - Instituto de Letras, Universidade Federal da Bahia.

CALMON, Pedro. História da Civilização Brasileira. $2^{\text {a }}$ edição. São Paulo: Comp. Editora Nacional, 1935.

CÂMARA JR, Joaquim Mattoso. Princípios de linguística Geral. 2. ed. revista e aumentada. Rio de Janeiro: Livraria Acadêmica, 1954.

CAMARA JR., Joaquim Mattoso. Línguas européias de ultramar: o português do Brasil. In: Câmara Jr., Mattoso. Dispersos. Seleção e introdução por Carlos Eduardo Falcão Uchôa. Rio de Janeiro: FGV, 1972[1963], p. 71-87.

CÂMARA JR., Joaquim Mattoso. História e estrutura da língua portuguesa. Rio de Janeiro: Padrão-Livraria Editora, 1975.

CANNECATTIM, Bernardo Maria de. Collecção de observações grammaticaes sobre a língua bunda, ou angolense e Diccionario abreviado da lingua congueza. 1859. $2^{\text {a }}$ edição. Lisboa: Imprensa Nacional, 1859.

CAPELO, Hermenegildo; IVENS, Roberto. De Benguela às Terras de Iácca: Descripção de uma Viagem na Africa Central e Occidental. volumes I e II (1881). Lisboa, 1881.

CARENO, Mary Francisca do. A linguagem rural do Vale do Ribeira: a voz e a vez das comunidades negras. Assis, 1992. Tese (Doutorado em Filologia e Linguística Portuguesa) - Faculdade de Ciências e Letras, Universidade Estadual Paulista.

CARENO, Mary Francisca do; PETTER, Margarida Maria Taddoni Petter. Observações Sobre O Uso da Negativa. Papia, THESAURUS, BRASILIA/DF, v. 3, nº 2, p. 98-109, 1994.

CARENO, Mary Francisca. Traços Sintáticos do Português Popular Brasileiro usado em Comunidades Negras Rurais. In: ZIMMERMANN, Klaus (Ed.). (Org.). Lenguas 
Criollas de Base Lexical Española y Portuguesa. Berlin-Alemanha: Vervuert, 1999, p. 503-523.

CARNEIRO, Edison. A linguagem popular da Bahia. Rio de Janeiro: [s.d.], 1951.

CARVALHO, Felix de. Falares crioulos do Brasil: um tema em debate. Rio de Janeiro, 1978. Dissertação (Mestrado em Linguística) - Departamento de Letras, Pontifícia Universidade Católica (PUC).

CARVALHO, Guilhermina Maria Bastos Mendes de. A inacusatividade na fala de comunidades rurais afro-brasileiras isoladas. Salvador, 2006. Dissertação (Mestrado em Letras e Linguística) - Universidade Federal da Bahia.

CASTRO, Comandante Eugênio de. Ensaios de Geographia lingüística e cultura brasileira. Rio de Janeiro: Graphica Sauer, 1941. Disponível: http://www.brasiliana.com.br/brasiliana/colecao/obras/154/Ensaios-de-geografialinguistica Acesso em 08/02/2013.

CASTRO, Yeda Pessoa de. Noticia de uma Pesquisa em África. Afro-Asia (UFBA), Salvador, v. 01, p. 41-56, 1965.

CASTRO, Yeda Pessoa de. Etnônimos Africanos e Formas Ocorrentes no Brasil. AfroAsia (UFBA), Salvador, v. 6-7, 1968, p. 63-82.

CASTRO, Yeda Pessoa de. A Sobrevivência das Línguas Africanas no Brasil: sua influência na linguagem popular da Bahia. Afro-Asia (UFBA), Salvador, v. 4-5, p. 2534, 1967.

CASTRO, Yeda Pessoa. Réplicas Populares. Revista Brasileira de Folclore, Rio de Janeiro, v. 18, p. 117-138, 1967.

CASTRO, Yeda Pessoa. Etnônimos Africanos e Formas Ocorrentes no Brasil. Afro-Asia (UFBA), Salvador, v. 6-7, p. 63-82, 1968.

CASTRO, Yeda Pessoa de. The Religious Terminology and Everyday Speech Vocabulary of an Afro-Brazilian Cult House. 1974. Dissertação (Mestrado em Línguas Africanas) - Universidade de Ifé. 
CASTRO, Yeda Pessoa de. De l'intégration de apports africains dans les parlers de Bahia au Brésil. Lubumbashi. 1976. Tese (Doutorado em línguas e literaturas africanas) - Université Nationale du Zäire, 2v. Universidade Federal da Bahia.

CASTRO, Yeda Pessoa de.. Religious Terminology and Everyday Speech Vocabulary of an Afro-Brazilian Cult House - Terminologia religiosa e o falar cotidiano em uma casa de culto afro-brasileira. 1974. Dissertação (Mestrado em Ciências Sociais) Universidade Federal da Bahia.

CASTRO, Yeda Pessoa. Colaboração à Antropologia Lingüística nos Estudos AfroBrasileiros. In: MARTINS, Cléo; LODI, Raul. (Org.). Faraimara: O Caçador Traz a Alegria. Rio de Janeiro: Pallas, 2000, p. 81-97. Publicado também em CASTRO, Yeda Pessoa. Antropologia e Lingüística nos Estudos Afro-Brasileiros. Afro-Asia (UFBA), Salvador, v. 12, p. 211-228, 1976.

CASTRO, Yeda Pessoa. Influências de línguas africanas no português do Brasil e níveis socioculturais de linguagem. Educação, Brasília, v.6, nº 25, p. 49-64, out./dez. 1977.

CASTRO, Yeda Pessoa de. África descoberta: uma história recontada. Revista de Antropologia (São Paulo), São Paulo, v. 23, 1980, p. 135-140.

CASTRO, Yeda Pessoa. Das Línguas Africanas ao Português Brasileiro. Afro-Asia (UFBA), Salvador, v. 14, p. 81-106, 1983.

CASTRO, Yeda Pessoa. L'Afrique Au Brasil, une Nouvelle Approche. Recherche Pedagoie Et Culture, Paris, nº 64, p. 7-10, 1983.

CASTRO, Yeda Pessoa. Os Falares Africanos na Interação Social do Brasil Colônia. In: MELLO, Linalda de Arruda (Org.). Sociedade, Cultura e Língua. João Pessoa: Editora Shorin, 1990, v. 01, p. 91-113.

CASTRO, Yeda Pessoa. O Ensino de Línguas Africanas no Brasil. In: LIMA, Ivan Costa; ROMÃO, Jeruse; SILVEIRA, Sônia Maria (Org.). Os Negros, os Conteúdos Escolares e a Diversidade Cultural. Florianópolis: Núcleo de Estudos Negros - NEN, 1998, p. 29-38. 
CASTRO, Yeda Pessoa. Falares Africanos na Bahia (um vocabulário Afro-Brasileiro). Rio de Janeiro: Topbooks, 2001.

CASTRO, Yeda Pessoa. A língua mina-jeje no Brasil: um falar africano em Outro Preto do séc. XVIII. Belo Horizonte: Fundação João Pinheiro, Secretaria de Cultura de Minas Gerais (Coleção Mineiriana), 2002.

CASTRO, Yeda Pessoa. Redescobrindo as línguas africanas. In: CHAVES, Rita; Carmen Secco; MACÊDO, Tania. (Org.). Brasil/África: Como se o mar fosse mentira. Maputo: Imprensa Universitária - Universidade Eduardo Mondlane, 2003, p. 359-374.

CASTRO, Yeda Pessoa. A Diversidade das Línguas Africanas e Atitudes Linguísticas no Relacionamento Brasil-África. In: MENEZES, Jaci Maria ferraz de; CASTRO, Yeda Pessoa; GONÇALVES, José Manuel. (Org.). Relações do Atlântico Sul: História e Contemporaneidade. Salvador: Editora UNEB, 2003, p. 35-38.

CASTRO, Yeda Pessoa. Falares africanos na Bahia. $2^{\mathrm{a}}$ ed. Rio de Janeiro: Academia Brasileira de Letras/Topbooks, 2005.

CASTRO, Yeda Pessoa. A influência das línguas africanas no português brasileiro. In: Secretaria Municipal de Educação - Prefeitura da Cidade do Salvador. (Org.). Pasta de textos da professora e do professor. Salvador: Secretaria Municipal de Educação, 2005.

CASTRO, Yeda Pessoa de. A matriz africana no português do Brasil. In: CARDOSO, Suzana Alice; MOTA, Jacyra; SILVA, Rosa Virgínia Mattos (Org.). Quinhentos anos de história lingüística do Brasil. Salvador: Secretaria de Cultura e Turismo do Estado da Bahia, 2006, p. 81-116.

CASTRO, Yeda Pessoa. Redescobrindo as línguas africanas. In: CHAVES, Rita, SECCO, Carmen; MACEDO, Tânia. (Org.). Luanda: Chá de Caxinde. São Paulo: UNESP, 2006, p. 361-376.

CASTRO, Yeda Pessoa. Línguas africanas e o português do Brasil. İrohin, v. 17, p. 3233, 2007.

CASTRO, Yeda Pessoa. O Português e as línguas africanas no Brasil colonial. In: SCHRADER-KNIFFKI, Martina; MORGENTHALER, Laura García. (Org.). Romania 
en interacción: Entre historia, contacto y política. Ensayos en homenaje a Klaus Zimmermann. Frankfurt/ Madrid: Vervuert/ Iberoamericana, 2007, p. 361-379.

CASTRO, Yeda Pessoa. Dimensão dos aportes africanos no Brasil. In: BACELAR, Jeferson; PEREIRA, Claudio. (Org.). Vivaldo da Costa Lima, interprete afro-brasileiro. Salvador: EDUFBA, 2007, p. 177-. Publicado também em CASTRO, Yeda Pessoa. Dimensão dos Aportes Africanos no Brasil. Afro-Asia (UFBA), Salvador, v. 16, p. 24$35,1995$.

CASTRO, Yeda Pessoa. African Languages and Brazilian Portuguese: a new approach. In: PETTER, Margarida Maria Taddoni; MENDES, Ronald Beline (Org.). Proceedings of the Special World Congresso of African Linguistics. São Paulo: Humanitas, p. 47-56, 2008 .

CASTRO, Yeda Pessoa. A participação das línguas africanas na construção do português do Brasil. KILOMBO Reveu Annueile Pluridisciplinaire du CERAFIA, v. 04, p. 61-68, 2008.

CASTRO, Yeda Pessoa. Towards a Comparative Approach of Bantuisms in Iberoamerica. In: PHAF-RHEINBERGER, Ineke; PINTO, Tiago de Oliveira. (Org.). AfricAmericas: Itineraries, Dialogues, and Sounds. Madrid / Frankfurt am Main: Iberoamericana-Vervuert, v. 119, p. 81-92, 2008.

CASTRO, Yeda Pessoa. African Languages and Brazilian Portuguese: a new approach. In: PETTER, Margarida Maria Taddoni; MENDES, Ronald Beline (Org.). Exploring the African Language Connection in the Americas - Proceedings of the Special World Congresso of African Linguistics (2008). São Paulo: Humanitas, 2009, p. 47-56.

CASTRO, Yeda Pessoa. O português do Brasil, uma intromissão nessa história. In: GALVES, Charlotte, GARMES, Helder, RIBEIRO, Fernando Rosa. (Org.). ÁfricaBrasil: caminhos da língua portuguesa. Campinas: Editora Unicamp, 2009, p. 175-184.

CASTRO, Yeda Pessoa. Marcas lexicais africanas em contextos afro-brasileiros. KILOMBO Reveu Annueile Pluridisciplinaire du CERAFIA, v. 05, p. 119-131, 2009.

CASTRO, Yeda Pessoa.A Identidade Tecida pela Palavra. Revista do Instituto Geográphico e Histórico da Bahia, v. 104, p. 30-45, 2009. 
CASTRO, Yeda Pessoa. A participação de falantes africanos na história do português do Brasil. In: GÄRTNER, Eberhard; SCHÖNBERGER, Axel (Org.). Estudos sobre o português brasileiro. Frankfurt: Valentia, 2009, v. 8, p. 85-98.

CASTRO, Yeda Pessoa. A participação de falantes africanos no português brasileiro: aspectos sócio-históricos e linguísticos. In: Instituto Internacional da Língua Portuguesa; Associação das Universidades de Língua Portuguesa. (Org.). Interprenetração da língua e culturas delem língua portuguesa na CPLP. $1^{\mathrm{a}}$ ed. Praia Cabo Verde: Instituto IILP e AULP, 2010, p. 106-115.

CAVALCANTE, Rerisson. A negação pós-verbal no português brasileiro: análise descritiva e teórica de dialetos rurais de afrodescendentes. Salvador, 2007. Dissertação (Mestrado em Letras) - Instituto de Letras, Universidade Federal da Bahia.

CAVALCANTE, Rerisson. Construções negativas no português falado em Salvador. Hyperion, Salvador, v. 1, p. 12, 2004.

CAVALCANTE, Rerisson. A negação sentencial. In: LUCCHESI, Dante; BAXTER, Alan; RIBEIRO, Ilza (Org.). Português afro-brasileiro. Salvador: Edufba, 2009, p. 251 - 266.

CAVALCANTE, Rerisson; FIGUEIREDO, Maria Cristina Vieira de. Complementos diretos e indiretos. In: LOBO, Tânia; OLIVEIRA, Klebson (Orgs). África à vista: dez estudos sobre o português escrito por africanos no Brasil do século XIX. Salvador: EDUFBA, 2009, p. 90-137.

CHAUÍ, Marilena de Souza. Contra a universidade operacional. Aula Magna da Faculdade de Arquitetura e Urbanismo (FAU-USP). 2014. Disponível em http://www.adusp.org.br/files/database/2014/tex_chaui.pdf e disponível em vídeo em http://www.adusp.org.br/index.php/campanha-salarial-2014cs/2076-aula-magna-demarilena-chaui-desvenda-universidade-operacional Acesso em 01.12.2014.

CHOMSKY, Noam. Derivation by phase. In: Hale Ken: a life in language. Cambridge: MIT Press, 2001b.

CINQUE, Guglielmo."A phrasal movement analysis of the Romanian DP". In: Studia Linguistica et Philologica in Honorem D. Irimia, 2004, pp. 129-142. 
CHISTINO, Beatriz Protti. "Português de gente branca" - certas relações entre língua e raça na década de 20. São Paulo, 2002. 339 folhas. Dissertação (Mestrado em Semiótica e Linguística Geral). Faculdade de Filosofia, Letras e Ciências Humanas, Universidade de São Paulo.

COELHO, Olga Ferreira; BORGES, Patrícia. O metatermo caso em duas gramáticas brasileiras do Período Colonial. Revista Todas as Letras (MACKENZIE. Online), v. 14, p. 167, 2012.

COELHO, Olga Ferreira. Os nomes da língua: configuração e desdobramentos do debate sobre a língua brasileira no século XIX. Revista do Instituto de Estudos Brasileiros, São Paulo, n. 47, 2008, p. 139-160.

COELHO, Olga Ferreira. O Português do Brasil em Macedo Soares (1938-1905). Límite. Revista de estudios portugueses y de lusofonía, v. 6, p. 199-215, 2012.

COELHO, Olga Ferreira. A anguzada lexicográfica luso-bundo-americana: língua e identidade nacional na segunda metade do século XIX. São Paulo, 2003. Tese (Doutorado em Linguística Geral) - Faculdade de Filosofia, Letras e Ciências Humanas. COELHO, Olga Ferreira. Serafim da Silva Neto (1917-1960) e a Filologia Brasileira: um ensaio historiográfico sobre o papel da liderança na articulação de um paradigma em ciência da linguagem. São Paulo, 1988. 185 páginas. Dissertação (Mestrado em Linguística Geral) - Faculdade de Filosofia, Letras e Ciências Humanas.

CONSTÂNCIO, Francisco Solano. Novo Diccionario crítico e etymologico da lingua portuguesa. Paris: Angelo Francisco Carneiro Junior Tip. de Casimir, 1836.

CÔRTES JUNIOR, Moacir da Silva. Clivadas e Pseudo-clivadas: um estudo de suas realizações estruturais no português rural afro-brasileiro. Salvador, 2006. Dissertação (Mestrado em Letras e Linguística) - Universidade Federal da Bahia. 
CÔRTES JUNIOR, Moacir da Silva. As sentenças clivadas: um estudo de suas realizações estruturais no português rural afro-brasileiro. Revista do GELNE (UFC), v. 221, p. 2212-2221, 2006.

COSTA, João; FIGUEIREDO SILVA, Maria Cristina. 2006. "Nominal and Verbal Agreement in Portuguese. An argument for Distributed Morphology". COSTA, J.; FIGUEIREDO SILVA, M. C. (Orgs.). Studies on Agreement, pp. 25-46.

CUNHA, Adan. A emergência da hipótese do Relativismo Linguístico em Edward Sapir (1884-1939). São Paulo, 2012. Dissertação (Mestrado em Linguística Geral) Faculdade de Filosofia, Letras e Ciências Humanas, São Paulo.

CUNHA, Ana Stela de Almeida. Remanescentes de línguas crioulas em comunidades negras rurais isoladas: ausência de concordância de gênero na linguagem do Cafundó. Anais do Gel, São Paulo, 1995.

CUNHA, Ana Stela de Almeida. Estruturas Tópicas na fala de duas comunidades negras rurais do Maranhão. Cadernos Teses Em Andamento, Campinas, v. 2, p. 36-39, 1998.

CUNHA, Ana Stela de Almeida. Perda de flexão verbal e preenchimento da categoria sujeito na variedade popular rural do PB falado nos quilombos do Maranhão. Revista Enapol, São Paulo, 1999.

CUNHA, Ana Stela de Almeida. O português falado em comunidades remanescentes de quilombos no Maranhão: divergências com a norma culta em relação ao preenchimento da categoria sujeito. Anais do Gel, Assis, São Paulo, 2000.

CUNHA, Ana Stela de Almeida. Olhar para a África para compreender o Brasil: a situação lingüística de Angola e o português falado nos quilombos do Maranhão. Revista Enapol, São Paulo: Humanitas, vol 1, p. 105-110, 2001.

CUNHA, Ana Stela de Almeida. Mudança paramétrica em curso nas estruturas coordenadas do português falado em terras de preto. Revista da Abralin, Rio de Janeiro, 2003. 
CUNHA, Ana Stela de Almeida. A atuação do Parâmetro do Sujeito Nulo na variedade popular rural do português do Brasil. São Paulo, 2003. Tese (Doutorado em Linguística) - Faculdade de Filosofia, Letras e Ciências Humanas, São Paulo.

CUNHA, Ana Stela de Almeida. Presença e contribuição das línguas negro-africanas para a constituição do português do Brasil: a alegada origem crioula e a variedade popular da língua falada nas terras de preto. Anais da Abanne, São Luís, Maranhão, 2003.

CUNHA, Ana Stela de Almeida; BUENO, André. Situações Linguageiras favorecedoras da difusão do português: A África na Historiografia Linguística Brasileira. Língua, Linguística \& Literatura, João Pessoa, vol. 2, n 1/2, 2004/2005, p. $33-48$.

CUNHA-HENCKEL, Rosa Alice. “Afrika in Brasilien”. Tópicos, nº 2, p. 14-15, 2001.

CUNHA-HENCKEL, Rosa Alice. Bantuísmos lexicais no português do Brasil com base no estudo da obra de José Lins do Rego. Brema, 2001. Tese (Doutorado) Universidade de Brema.

CUNHA-HENCKEL, Rosa Alice. Brasileirismos de origem africana. In: GROBE, S.; SCHÖNBERGER, A. (Orgs.). Ex oriente lux. Festschrift Eberhard Gärtner zu seinem 60. Geburtstag. Frankfurt am Main: valentia, 2002, p. 89-102.

CUNHA-HENCKEL, Rosa Alice. "Bantuísmos lexicais no português do século XVIII". In: THIELEMANN, Werner (Ed.). Século das Luzes - Portugal-Portugal e Espanha, o Brasil e a Região do Rio da Prata. Frankfurt am Main: TFM, 2006.

CUNHA-HENCKEL, Rosa Alice. "Africanismos e brasileirismos lexicais de matriz africana na imprensa brasileira". Martius-Staden-Jahrbuch, São Paulo, no 54, p. 65-77, 2007.

DAUZAT, Albert. La géographie linguistique. E. Flammarion, 1922.

DIAS, Pedro. Arte da lingua de Angola, oeferecida(sic) a virgem senhora $n$ do rosario, may, \& senhora dos mesmos pretos. Lisboa: Officina de Miguel Deslandes, 1697.

DIETRICH, Wolf. Bibliografia da Língua Portuguesa no Brasil. Tübingen: Narr, 1980. 
ELIA, Sílvio. O problema da língua brasileira. Rio de Janeiro: Instituto Nacional do livro/MEC, 1960[1940].

ELIA, Sílvio. Ensaios de filologia. Rio de Janeiro: Livraria Acadêmica, 1963.

ELIA, Sílvio. O problema da língua brasileira. Rio de Janeiro: Instituto Nacional do Livro/Ministério da Educação e Cultura, 1961[1940].

ELIA, Sílvio. A unidade linguística no Brasil. Rio de Janeiro: Padrão, 1979.

ELIA, Sílvio; CASTILHO, Ataliba Teixeira de. O Português do Brasil. Apêndice ao livro de ILARI, Rodolfo. Linguística Românica. São Paulo, Ática, 1992, 185 p., IN Confluência, Revista do Instituto de Língua Portuguesa do Liceu Literário Português, n. ${ }^{\circ}$ 5, pp.88-104, Rio de Janeiro, Ed. Lucerna Ltda., $1^{\circ}$ semestre de 1993.

FERNANDÉZ, Fernando Ortiz. Glossário de Afronegrismos. Habana: Imprenta, 1924.

FERNANDÉZ, Fernando Ortiz. La africanía de la música folklórica de Cuba. Habana: Ediciones Cardenas y Cia, 1950.

FERREIRA, Aurélio Buarque de Holanda. Novo Aurélio: dicionário da língua portuguesa: Século XXI. São Paulo: Nova Fronteira, 1999.

FERREIRA, Carlota. "Remanescentes de um falar crioulo brasileiro: Helvécia-Bahia." In: FERREIRA, Carlota et al. Diversidade do Português do Brasil. Salvador: PROED/UFBA, 1969, p. 21-31.

FERREIRA, C. da S. Remanescentes de um falar crioulo brasileira. Diversidade do Português do Brasil. Estudos da dialetologia rural e outros. Salvador: Centro Editorial e Didático, Universidade Federal da Bahia, 1994, p. 21-32.

FERREIRA, Cinthia Carla. A variação do pronome sujeito na fala da comunidade Kalunga. Brasília, 2003. 102f. Dissertação (Mestrado em Linguística) - Instituto de Letras, Universidade de Brasília.

FERREIRA, Graziele de Lourdes Novato. Cinzento: memória de uma comunidade negra remanescente de quilombo. São Paulo, 1999. Dissertação (Mestrado em Ciências Sociais) - Faculdade de Filosofia, Comunicação, Letras e Artes, Pontifícia Universidade de São Paulo. 
FIGUEIREDO, Maria Cristina Vieira de. O objeto direto anafórico no dialeto rural afrobrasileiro. Salvador, 2004. 149 Folhas. Dissertação (Mestrado em Letras e Linguística) - Instituto de Letras, Universidade Federal da Bahia.

FIGUEIREDO, Maria Cristina Vieira de. O objeto direto anafórico no dialeto rural afrobrasileiro do estado da Bahia - versão preliminar. Inventário (UFBA), v. 5, 2006.

FIGUEIREDO, Maria Cristina Vieira de. O objeto nulo no português rural baiano. Teoria temática e elipse de DP. Salvador, 2009. 207 folhas. Tese (Doutorado em Letras e Linguística) - Instituto de Letras, Universidade Federal da Bahia.

FIGUEIREDO, Maria Cristina Vieira de. Objeto Direto Anafórico: a categoria vazia e o pronome lexical. In: LUCHESI, Dante; BAXTER, Alan; RIBEIRO, Ilza. (Org.). $O$ Português Afro-brasileiro. Salvador: Edufba, 2009, p. 409-427.

FIGUEIREDO, Maria Cristina Vieira de; LUCCHESI, Dante. As formas variáveis de realização do objeto direto anafórico nas duas grandes vertentes do Português brasileiro: a rural e a urbana. Revista Outros Sertões, v. 1, p. 1-341, 2009.

FIGUEIREDO, Maria Cristina Vieira de; RIBEIRO, Ilza. As Sentenças Relativas em Atas Escritas por Africanos no Brasil Oitocentista (1832-1842). In: MEIRE, Vivian. (Org.). O Português Brasileiro: Estudos Funcionalistas e Sociolinguísticos. Salvador: EDUNEB, 2009.

FONSECA, Hely Dutra Cabral da. Marcas do passado no Português do Brasil e D'Angola. Revista Humanas, UFES, v. 2, p. 1-12, 2010.

FRANÇA, Nilcéia Albuquerque. Origens do Português no Brasil: Da crioulização ao Português brasileiro. Revista de História Regional, v. 7, 2004.

FREYRE, Gilberto. Casa grande e senzala: A formação da família brasileira sob o regime da economia patriarcal. São Paulo: Global, 2001[1933].

FREYRE, Gilberto. Sobrados e mucambos: decadencia do patriarchado rural no Brasil. Vol. 64. Companhia editora nacional, 1936.

FRY, Peter; VOGT, Carlos, GNERRE, Maurizio. Las lenguas secretas de Cafundó. Punto de vista, v.9, n. 3, p.26-32, 1980. 
FRY, Peter Henry; VOGT, Carlos Alberto. Ditos e Feitos da Falange Africana do Cafundó e da Calunga de Patrocínio. Revista de Antropologia (São Paulo), São Paulo, v. XXVI, p. 65-93, 1983.

FRY, Peter Henry; VOGT, Carlos. A Descoberta do Cafundó. Religião \& Sociedade, Rio de Janeiro, v. 8, p. 24-40, 1983.

FRY, Peter; VOGT, Carlos e GNERRE, Maurizio. Mafambura e Caxapura: na encruzilhada da identidade. Dados - Revista de Ciências Sociais, Rio de Janeiro, v. 24, n 3 , p. 373-389, 1981. Publicado também (1) FRY, Peter (Org.). Para inglês ver: identidade e política na cultura brasileira. Rio de Janeiro: Zahar, p. 116-135, 1982. (2) Cadernos de Estudos Linguísticos, nº 6, p. 111-124, 1984.

GALVES, Charlotte. O papel das línguas africanas na formação do português brasileiro: (mais) pistas para uma nova agenda de pesquisa. Gragoatá (UFF), v. 24, p. 145-164, 2008.

GALVES, Charlotte; LOBO, Tânia. Ordem dos clíticos. In: Lobo, Tânia; Oliveira, Klebson. (Org.). África à vista: dez estudos sobre o português escrito por africanos no Brasil do século XIX. Salvador: EDUFBA, 2009, p. 174-207.

GARCÍA, DE DIEGO. "V. Contribución al Diccionario Hispánico Etimológico.", 1923.

GARCIA, Rodolfo. Dicionário de Brasileirismos (peculiaridades pernambucanas). Rio de Janeiro: J Ribeiro dos Santos, 1915.

GIESE, W. The fonology of the speech of negroes in early Spanish drama. Hispanic review, 14, p. 322-339, 1932.

GONÇALVES, Eugênia Dias. Os falares de Angola da Irmandade do Rosário de Belo Horizonte. FUNDAC Informa, Belo Horizonte, p. 5, [1994?].

GONÇALVES, Eugênia Dias. O vocabulário dos Tata n' Ganga Mukice da Irmandade de N. S. do Rosário do Bairro Jatobá, Belo Horizonte, Minas Gerais. Belo Horizonte: FAFI-BH, 1995.

GUY, Gregory R. A questão da crioulização no português do Brasil. In: ZILLES, Ana In: ZILLES, Ana Maria Stahl (Org.). Estudos de variação linguística no Brasil e no Cone Sul. Porto Alegre: Editora da UFRGS, 2005, p.15-62. 
GUY, Gregory. Linguistic variation in Brazilian Portuguese: aspects of phonology, sintax and language history. PhD. 1981. Dissertation. University of Pennsylvannia. Ann Arbor: University Microfilms Internacional.

GUY, Gregory. On the nature and the origins of popular Brazilian Portuguese. Estudios sobre Español de América y Linguistica Afroamericana. Bogotá: Instituto Caro y Cuervo, 1989, p. 227-245.

HOLM, John. "Creole influence on popular Brazilian Portuguese”. In: GILBERT, G. (ed.). Pidgin and Creole Languages. Honolulu: University of Hawaii Press, 1987, p. 406-429.

HOLM, John. Popular Brazilian Portuguese; a semi-creole. In: D’ANDRADE, Ernesto; KIHM, Alain (Org.). Actas do Colóquio sobre Crioulos de Base Lexical Portuguesa. Lisboa: Colibri, 1992, p. 37-66.

HOLM, John; LORENZINO, Gerardo; MELLO, Heliana. Ribeiro de. Grados de estruturación: El Español Del Caribe Y El Portugues Vernáculo Brasileño. In: ORTIZ, José (Org.). Homenaje a Manuel Alvarez Nazario. $1^{\text {a }}$ ed. Frankfurt: Vervuert, 1999, p. 43-60.

HOLM, John; MELLO, Heliana Ribeiro de. Interpretação das origens do Português Vernáculo Brasileiro à luz de uma análise sociolinguística de dados demográficos. In: IGLA, Birgit; STOLZ, Thomas (Eds). Was ich noch sagen wollte... Festschrift für Norbert Boretzky zum 65. Geburtstag. Berlin: Akademie Verlag, pp. 223-236, 2002.

HOLM, John; MELLO, Heliana Ribeiro de. Restructured Portuguese: from Africa to Brazil. In: HUBER, Magnus; PARKVALL, Mikael. (Org.). Spreading the word. $1^{\text {a }}$ ed. Londres: Westminster University Press, 1999, v. 1, p. 165-176.

HOUAISS, Antônio. Dicionário Houaiss da língua portuguesa. Rio de Janeiro: Objetiva, 2001.

HOUAISS, Antônio. O português no Brasil: pequena enciclopédia da cultura brasileira. Rio de Janeiro: UNIBRADE, 1985. 
GUY, Gregory R. Parallel variability in American dialects of Spanish and Portuguese. In: SANKOFF, D.; CEDERGREN, H. (Ed.). Variation Omnibus. Carbondale; Edmonton: Linguistic Research, 1981b. p.85-93.

JEROSLOW, E. H. M. Creole Characteristics in Rural Brazilian Portuguese. 1975. Paper Presented at the Internacional Conference on Pidgins and Creoles, University of Hawaii.

JUCÁ FILHO, Cândido. Língua Nacional - As diferenciações entre o português de Portugal e o do Brasil autorizam a existência de um ramo dialetal do português peninsular?. Rio de Janeiro: Estabelecimento gráphico Apollo, 1937.

KOERNER, Ernst Frideryk Konrad. Practicing linguistic historiography: selected essays. Vol. 50. Amsterdam: John Benjamins Publishing, 1989.

KOLBE, Frederick William. An English-Herero dictionary: with an introduction to the study of Herero and Bantu in general. Vol. 1. JC Juta, 1883.

KOLBE, Frederick William. A language-study based on Bantu: or, An inquiry into the laws of root-formation, the original plural, the sexual dual, and the principles of wordcomparison. Trübner \& co, 1888.

KUHN, Thomas. A estrutura das revoluções científicas. Tradução de Beatriz Vianna Boeira, Nelson Boeira. São Paulo: Perspectiva, 2007 [1962].

LAYTANO, Dante de. Os africanismos do dialeto gaúcho. Separata da Revista do Instituto Histórico e Geográfico do Rio Grande do Sul, Porto Alegre, v.16, n.2, p.7-66, 1936.

LAYTANO, Dante de. O linguajar do gaúcho brasileiro. Porto Alegre: Escola Superior de Teologia São Lourenço de Brindes, 1981.

LEDA, João. A quimera da lingua brasileira. Manaus: S. Ed, 1939.

LEITE DE VASCONCELLOS, José. Esquisse d'une dialectologie portugaise. Aillaud \& cie., 1901. 
LEITE DE VASCONCELLOS, José. "Língua de preto num texto de Henrique da Mota” In: Estudos de filologia portuguesa. Rio: Livros de Portugal, 1933.

LEITE, Serafim. História da companhia de Jesus no Brasil. Rio de Janeiro: Instituto Nacional do Livro, 1938.

LEITE, Solidônio. A lingua portuguesa no Brasil. Rio de Janeiro: Editores J. Leite e Cia, 1922.

LEMLE, Miriam; NARO, Anthony J. "Competências básicas do português". Relatório final de pesquisa apresentado às instituições patrocinadoras, Fundação MOBRAL e Fundação Ford. Rio de Janeiro: Fundação Movimento Brasileiro de Alfabetização, 1977.

LIMA, Ivana Stolze. As rusgas da identidade. Rio de Janeiro, 1831-1833. Acervo (Rio de Janeiro), Rio de Janeiro, v. 15, nº 1, p. 23-37, 2002.

LIMA, Ivana Stolze. A língua brasileira e os sentidos de nacionalidade e mestiçagem no Império do Brasil. Topoi. Revista de História, Rio de Janeiro, v. 7, dez. 2003, p. 334356, 2004.

LOBO, Tânia Conceição Freire; RIBEIRO, Ilza. A concordância de número entre verbo e sujeito em textos escritos por negro forro na Bahia do século XIX. Filologia $e$ Lingüística Portuguesa, São Paulo, v. 6, p. 199-220, 2004. Publicado também em: A concordância de número entre verbo e sujeito em textos escritos por negro forro na Bahia do século XIX. In: COSTA, Sônia Bastos Borba; MACHADO FILHO, Américo Venâncio Lopes. (Org.). Do português arcaico ao português brasileiro. Salvador: EDUFBA, 2004, p. 67-82.

LIMA, Ivana Stolze. Línguas malditas. Revista de História da Biblioteca Nacional, n. 9, abril de 2006.

LIMA, Ivana Stolze. Entre a língua nacional e a fala caçanje. Representações sociais sobre a língua no Rio de Janeiro. In: COSTA, Wilma Peres; OLIVEIRA, Cecília Helena de Salles. (Org.). De um império a outro. Formação do Brasil, séculos XVIII e XIX. São Paulo: HUCITEC/FAPESP, p. 63-98, 2007. 
LOBO, Tânia; RIBEIRO, Ilza; CARNEIRO, Zenaide; ALMEIDA, Norma (Orgs.). Para a história do português brasileiro. Vol. VI: novos dados, novas análises. Salvador: EDUFBA, 2006.

LUCCHESI, Dante. Sistema, Mudança e Linguagem: um percurso da linguística neste século. Lisboa, 1993. Dissertação (Mestrado em Linguística Portuguesa Histórica) Universidade de Lisboa.

Lucchesi, Dante. 1998. Sistema, mudança e linguagem: um percurso da linguística neste século. Lisboa: Colibri.

LUCCHESI, Dante. A questão da formação do português popular do Brasil. A cor das letras, n 3, p. 73-100, 1999.

LUCCHESI, Dante. A variação na concordância de gênero em dialetos despidgnizantes e descrioulizantes do português do Brasil. In: Klaus Zimmermann. (Org.). Lenguas criollas de base lexical española y portuguesa. Madrid: Ibero-Americana, 1999, p. 477502.

LUCCHESI, Dante. Conclusão. In: LUCCHESI; Dante; BAXTER, Alan; RIBEIRO, Ilza. (Org.). O Português Afro-Brasileiro. $1^{\mathrm{a}}$ ed. Salvador: EDUFBA, v. 1, p. 513-548, 2009.

LUCCHESI, Dante. A variação na concordância de gênero em uma comunidade de fala afro-brasileira: novos elementos sobre a formação do português popular do Brasil. Rio de Janeiro, 2000. Doutorado (Tese em Linguística) - Faculdade de Letras, Universidade Federal do Rio de Janeiro.

LUCCHESI, Dante. O português se teria crioulizado no Brasil? - refletindo sobre uma velha questão. Afrika, Asien, Brasilien, Portugal, Frankfurt, Alemanha, v. 2, p. 25-43, 2002.

LUCCHESI, Dante. O conceito de transmissão linguística irregular e o processo de formação do português do Brasil. In: RONCARATI, Cláudia; ABRAÇADO, Jussara. (Org.). Português Brasileiro: contato lingüístico, heterogeneidade e história. $1^{\mathrm{a}}$ ed. Rio de Janeiro: 7letras, 2003, p. 272-284. 
LUCCHESI, Dante. A participação do contato entre línguas na formação do português popular do Brasil: Novas evidências empíricas. In: FERNÁNDEZ, Mauro; FERNÁNDEZ-FERREIRO, Manuel; VEIGA, Nancy Vázquez. (Org.). Los criollos de base ibérica. $1^{\mathrm{a}}$ ed. Madrid: Iberoamericana, 2005, v. 24, p. 215-226.

LUCCHESI, Dante. Contato entre línguas e variação paramétrica: o sujeito nulo no português afro-brasileiro. Lingua(gem), Macapá-Amapá, v. 1, nº 2, p. 63-91, 2005.

LUCCHESI, Dante. Reanálise da variação na concordância de gênero em um dialeto afro-brasileiro. Revista do GELNE (UFC), Fortaleza, v. 3, n.2, p. 27-30, 2005.

LUCCHESI, Dante; BAXTER, Alan. Processos de crioulização na história sociolinguística do Brasil. In: CARDOSO, Suzana; MOTA, Jacyra; MATTOS E SILVA, Rosa Virgínia. (Org.). Quinhentos Anos de História Lingüística do Brasil. 1 ${ }^{\text {a }}$ ed. Salvador: Secretaria da Cultura e Turismo do Estado da Bahia, v. 01, p. 163-218, 2006.

LUCCHESI, Dante. Alterações no quadro dos pronomes pessoais e na aplicação da regra de concordância verbal nas normas culta e popular como evidências da polarização sociolingüística do Brasil e da relevância histórica do contato entre línguas. Lingüistica. Madrid, v. 19, p. 52-87, 2007.

LUCCHESI, Dante. Africanos, crioulos e a língua portuguesa. In: LIMA, Ivana Stolze; CARMO, Laura do (Org.). História social da língua nacional. Rio de Janeiro: Casa de Rui Barbosa, 2008b. p.151-180.

LUCCHESI, Dante. Aspectos gramaticais do português brasileiro afetados pelo contato entre línguas: uma visão de conjunto. In: RONCARATI, Cláudia; ABRAÇADO, Jussara. (Org.). Português Brasileiro II: contato lingüístico, heterogeneidade e história. $1^{\text {a }}$ ed. Niterói: EdUFF, v. 2, p. 366-390, 2008.

LUCCHESI, Dante. A concordância nominal em estruturas passivas e de predicativo do sujeito em comunidades rurais afro-brasileiras isoladas no contexto da história sociolinguiística do Brasil. In: VOTRE, Sebastião; RONCARATI, Cláudia Roncarati. (Org.). Anthony Julius Naro e a Lingüística no Brasil: uma homenagem acadêmica. $1^{\mathrm{a}}$ ed. Rio de Janeiro: 7Letras, v. 1, p. 148-168, 2008. 
LUCCHESI, Dante; BAXTER, Alan; RIBEIRO, Ilza. (Org.). 2009. O português afrobrasileiro. Salvador: EDUFBA.

LUCCHESI, Dante. História do Contato entre Línguas no Brasil. In: LUCCHESI; Dante; BAXTER, Alan; RIBEIRO, Ilza. (Org.). O Português Afro-Brasileiro. $1^{\text {a }}$ ed.Salvador: EDUFBA v. 1, 2009, p. 41-73.

LUCCHESI, Dante. A concordância de gênero. In: LUCCHESI; Dante; BAXTER, Alan; RIBEIRO, Ilza. (Org.). O Português Afro-Brasileiro. $1^{\mathrm{a}}$ ed. Salvador: EDUFBA, v. 1, 2009, p. 295-318.

LUCCHESI, Dante. A realização do sujeito pronominal. In: LUCCHESI; Dante; BAXTER, Alan; RIBEIRO, Ilza. (Org.). O Português Afro-Brasileiro. $1^{\text {a }}$ ed. Salvador: EDUFBA, v. 1, 2009, p. 167-184.

LUCCHESI, Dante. A concordância em estruturas passivas e de predicativo do sujeito. In: LUCCHESI; Dante; BAXTER, Alan; RIBEIRO, Ilza. (Org.). O Português AfroBrasileiro. 1a ed. Salvador: EDUFBA, v. 1, p. 373-387, 2009.

LUCCHESI, Dante. Aspectos da gramática do português brasileiro afetados pelo contato entre línguas: a flexão de caso dos pronomes pessoais. In: MEIRA, Vivian. (Org.). Português Brasileiro: estudos funcionalistas e sociolinguísticos. $1^{\text {a }}$ ed. Salvador: EDUNEB, v. 1, p. 41-79, 2009.

LUCCHESI, Dante. História do Contato entre Línguas no Brasil. In: LUCCHESI; Dante; BAXTER, Alan; RIBEIRO, Ilza. (Org.). O Português Afro-Brasileiro. $1^{\mathrm{a}}$ ed. Salvador: EDUFBA, v. 1, p. 41-73, 2009.

LUCCHESI, Dante; BAXTER, Alan; SILVA, Jorge Augusto Alves da Silva. A concordância verbal. In: LUCCHESI; Dante; BAXTER, Alan; RIBEIRO, Ilza. (Org.). O Português Afro-Brasileiro. 1ª ed. Salvador: EDUFBA, v. 1, p. 331-371, 2009.

LUCCHESI, Dante; ARAÚJO, Silvana Silva de Farias Araújo. A representação da primeira pessoa do plural. In: LUCCHESI; Dante; BAXTER, Alan; RIBEIRO, Ilza. (Org.). O Português Afro-Brasileiro. $1^{\text {a }}$ ed. Salvador: EDUFBA, v. 1, p. 457-469, 2009. 
LUCCHESI, Dante; ARAÚJO, Silvana Silva de Farias Araújo. O sistema de expressão de posse. In: LUCCHESI; Dante; BAXTER, Alan; RIBEIRO, Ilza. (Org.). O Português Afro-Brasileiro. $1^{\text {a }}$ ed. Salvador: EDUFBA, v. 1, p. 489-511, 2009.

LUCCHESI, Dante; BAXTER, Alan. A Transmissão Linguística Irregular. In: LUCCHESI; Dante; BAXTER, Alan; RIBEIRO, Ilza. (Org.). O Português AfroBrasileiro. $1^{\text {a }}$ ed. Salvador: EDUFBA, v. 1, p. 101-124, 2009

LUCCHESI, Dante; BAXTER, Alan; SILVA, Jorge Augusto Alves da; Figueiredo, Maria Cristina Vieira de. O Português Afro-Brasileiro: as comunidades analisadas. In: LUCCHESI; Dante; BAXTER, Alan; RIBEIRO, Ilza. (Org.). O Português AfroBrasileiro. $1^{\text {a }}$ ed. Salvador: EDUFBA, 2009, v. 1, p. 75-100.

LUCCHESI, Dante; MENDES, Elisângela dos Passos. A flexão de caso dos pronomes pessoais. In: LUCCHESI; Dante; BAXTER, Alan; RIBEIRO, Ilza. (Org.). O Português Afro-Brasileiro. $1^{\mathrm{a}}$ ed. Salvador: EDUFBA, v. 1, 2009, p. 471-488.

LUCCHESI, Dante; RIBEIRO, Ilza. A metodologia. In: LUCCHESI; Dante; BAXTER, Alan; RIBEIRO, Ilza. (Org.). O Português Afro-Brasileiro. $1^{\mathrm{a}}$ ed. Salvador: EDUFBA, v. 1, 2009, p. 155-166.

LUCCHESI, Dante; RIBEIRO, Ilza. Teorias da estrutura e da mudança linguísticas e contato entre línguas. In: LUCCHESI; Dante; BAXTER, Alan; RIBEIRO, Ilza. (Org.). O Português Afro-Brasileiro. 1ª ed. Salvador: EDUFBA, v. 1, p. 125-153, 2009.

LUCCHESI, Dante; MELLO, Camila Ferreira de. A alternância dativa no português afro-brasileiro: um processo de reestruturação original da gramática. Papia, Brasília, v. 19, p. 153-184, 2009.

LUCCHESI, Dante; MELLO, Camila. Alternância dativa. In: LUCCHESI; Dante; BAXTER, Alan; RIBEIRO, Ilza. (Org.). O Português Afro-Brasileiro. $1^{\text {a }}$ ed. Salvador: EDUFBA, v. 1, p. 427-456, 2009.

LUCCHESI, Dante. A diferenciação da língua portuguesa no Brasil e o contato entre línguas. Estudos de Linguistica Galega, v. 4, 2012, p. 45-65. 
MACEDO SOARES, Antônio Joaquim de. Dicionario Brazileiro da Língua Portuguesa. Rio de Janeiro: Typ. De G. Leuzinger \& Filhos, 1889.

MACEDO SOARES, Antônio Joaquim de. Estudos lexicográficos do dialeto brasileiro. [Org. Julião Rangel de Macedo Soares]. Rio de Janeiro: Publicação da Revista do IHGB, 1942[1874/1891].

MARCUSCHI, Luíz Antônio. (Org). KAZUE, S. M. de Barros (Colab.). Quem é quem na pesquisa em Letras e linguística no Brasil. Recife: ANPOLL, 1992.

MARROQUIM, Mário. A Língua do nordeste (Alagôas e Pernambuco). São Paulo: Companhia Editora Nacional, 1934.

MATTOS E SILVA, Rosa Virgínia. Aspectos do contato linguístico no Brasil. Universitas, Salvador, n.24, 1979, p. 83-95.

MATTOS e SILVA, Rosa Virgínia. Português brasileiro: raízes e trajetórias (Para a construção de uma história). Discursos, Lisboa, n.3, p. 75-92, 1993.

MATTOS e SILVA, Rosa Virgínia. A socio-história do Brasil e a heterogeneidade do português brasileiro. ABRALIN (Curitiba), São Paulo, n.17, p. 73-85, 1995.

MATTOS e SILVA, Rosa Virgínia. A formação de uma área dialetal do português. Papiá. Revista de crioulos de base ibérica, Brasília, v. 09, p. 09-19, 1997.

MATTOS E SILVA, Rosa Virgínia. Uma compreensão histórica do português brasileiro: velhos problemas revisitados. Conferência para Concurso Público de Professor Titular. Bahia: UFBA, 1999, mimeografado. Publicado também em: MATTOS e SILVA, Rosa Virgínia. Uma compreensão histórica do português brasileiro: velhos problemas revisitados. Estudos Lingüísticos e Literários, Salvador, n. 25/26, p. 250-283, 2002.

MATTOS e SILVA, Rosa Virgínia. A língua portuguesa em perspectiva histórica: do português europeu para o português brasileiro. Estudos Lingüísticos (São Paulo), São Paulo, n. XXIX, p. 16-32, 2000. 
MATTOS e SILVA, Rosa Virgínia. Uma interpretação para a generalizada difusão da língua portuguesa em território brasileiro. Gragoatá (UFF), Niterói, v. 9, p. 11-27, 2000. Publicado também em: MATTOS e SILVA, Rosa Virgínia. Uma interpretação para a generalizada difusão da língua portuguesa no Brasil. Revista da Academia de Letras da Bahia, Salvador, n.45, p. 105-126, 2002.

MATTOS e SILVA, Rosa Virgínia. A gramaticalização numa perspectiva diacrônica: contribuições baianas. Estudos Lingüísticos e Literários, Salvador, n. 29/30, p. 135-147, 2003.

MATTOS e SILVA, Rosa Virgínia. O português no Brasil: sua formação na complexidade multilingüística do Brasil colonial e pós-colonial. Leituras Contemporâneas. Salvador, v. 1, n.1, p. 95-105, 2004. Publicado também: O português brasileiro: sua formação na complexidade multilingüística do Brasil colonial e póscolonial. In: COSTA, Sônia; MACHADO FILHO, Américo. (Org.). Do português arcaico ao português brasileiro. Salvador: Edufba, 2004, p. 115-137.

MATTOS e SILVA, Rosa Virgínia; MACHADO FILHO, Américo Venâncio Lopes. A variação ter/haver na primeira metade do século XIX em textos escritos por africanos e afro-descendentes. Lingüistica (Madrid), São Paulo, v. 15-16, p. 161-174, 2004.

MATTOS e SILVA, Rosa Virgínia. Teorias da mudança linguística e a sua relação com a(s) história(s) da língua(s). Linguística - Revista de Estudos Linguísticos da Universidade do Porto. Porto, v. 3, p. 39-53, 2008.

MATTOS e SILVA, Rosa Virgínia; MACHADO FILHO, Américo Venâncio Lopes. Variação TER/HAVER. In: LOBO, Tânia; OLIVEIRA, Klebson. (Org.). África à vista. Salvador: EDUFBA, p. 338-351, 2009.

MATTOS e SILVA, Rosa Virgínia; MACHADO FILHO, Américo Venâncio Lopes. Entre duas diásporas: o português e as línguas africanas no Brasil. In: OLIVEIRA, Klebson; CUNHA E SOUZA, Hirão; SOLEDADE, Juliana. (Org.). Do português arcaico ao português brasileiro: outras histórias. Salvador: EDUFBA, 2009, p. 297-304.

MEILLET, Antoine. La méthode comparative en linguistique historique. Oslo: $\mathrm{H}$. Aschehoug \& Company, 1925. 
MEIRA, Vivian. $O$ uso do modo subjuntivo em orações relativas e completivas no português afrobrasileiro. 2006. Dissertação (Mestrado em Letras e Linguística) Universidade Federal da Bahia, Salvador.

MEIRA, Vívian. O uso do modo subjuntivo em comunidades rurais afro-brasileiras. Revista da ABRALIN, v. 6, 2007.

MEIRA, Vívian. O uso do subjuntivo nas orações relativas e completivas no português afro-brasileiro. Gragoatá (UFF), v. 21, 2007.

MEIRA, Vívian. O uso do modo subjuntivo em orações relativas, completivas e adverbiais no português afro-brasileiro. Estudos Linguísticos (São Paulo), v. XXXVI, p. 409-418, 2007.

MEIRA, Vívian. O emprego do modo subjuntivo. In: LUCCHESI; Dante; BAXTER, Alan; RIBEIRO, Ilza. (Org.). O Português Afro-Brasileiro. $1^{\mathrm{a}}$ ed. Salvador: EDUFBA, 2009, v. 1, p. 389-407.

MEIRA, Vívian. O português falado no Brasil: evidências sócio-históricas. In: MEIRA, Vivian. (Org.). Português Brasileiro: Estudos Funcionalistas e Sociolinguísticos. Salvador: EDUNEB, 2009.

MELLO, Heliana Ribeiro de. A comparison of Brazilian Vernacular Portuguese and São Tomense Creole. New York, 1993. Dissertação (Mestrado em Linguística) - City University of New York (CUNY).

MELLO, Heliana Ribeiro de. The Genesis and Developmento of Brazilian Vernacular Portuguese. Ann Arbor: University Microfilm International, v. 1, 1997.

MELLO, Heliana Ribeiro de; BAXTER, Alan; HOLM, John; MEGENNEY, W. Português Vernáculo do Brasil. In: PERL, Matthias; SCHWEGLER, Armin Schwegler. (Org.). America negra: panoramica actual de los estudios linguisticos sobre variedades hispanas, portuguesas y criollas. $1^{\mathrm{a}}$ ed. Frankfurt: Vervuert, v. 1, p. 71-137, 1998.

MELLO, Heliana Ribeiro de. The genesis and development of Brazilian vernacular Portuguese. Estocolmo: The Creolist Archives (Universitet Stockholms), 1999. 
MELLO, Heliana Ribeiro de. Português padrão, português não-padrão e a hipótese do contato lingüístico. In: ALKMIN, Tânia Maria. (Org.). Para a história do português brasileiro. Novos estudos. São Paulo: Humanitas, v. III, p. 341-358, 2002.

MELLO, Heliana Ribeiro de. Modelos de formação da língua nacional sob a perspectiva do contato de populações. In: LIMA, Ivana Stolze; CARMO, Laura do (Org.). História social da língua nacional. Rio de Janeiro: Edições Casa de Rui Barbosa, p. 295-314, 2008.

MELO, Gladstone Chaves de. A língua do Brasil. [s.1.]: Lucas/Agir, 1946.

MENDONÇA, Renato. 1935[1933]. A influência africana no português do Brasil. Prefácio de Rodolfo Garcia. São Paulo: Companhia Editora Nacional. Série V Brasiliana, Volume XLVI, $2^{a}$ edição ilustrada com mapas e gravuras.

MENDONÇA, Renato. O Português do Brasil: origem, evolução e tendências. Rio de Janeiro: Civilização Brasileira, 1936.

MENDONÇA, Renato. O negro e a cultura no Brasil: breve histórico de estudos afrobrasileiros de linguística, etnografia e sociologia. In: HERSKOVITS, Melville et al. $O$ negro no Brasil: trabalhos apresentados ao II Congresso Afro-Brasileiro (Bahia). Rio de Janeiro: Civilização Brasileira, p. 99-125, 1940. Biblioteca de divulgação científica, 20.

MINGAS, Amélia. Interferência do kimbundo no português falado em Lwanda. Luanda: Campo das Letras, 2000.

MONTEIRO, C. do R. A linguagem dos cantadores. Tese apresentada em concurso Congregação do Colégio Pedro II, Rio de Janeiro, 1933.

MONTEIRO, Clóvis. Português da Europa e Português da América - Aspectos da evolução do nosso idioma. Rio de Janeiro: J. Leite, 1931.

MORAIS SILVA, Antonio. Dicionário da Língua Portugueza. SILVA, A. de M. Diccionario da lingua portugueza. Lisboa: Officina de Simão Thaddeo Ferreira, 1789. 
MÜLLER, Max. (1867-68). Nouvelles leçons sur la science du langage: cours professé à l'Institution Royale de la Grande-Bretagne en l'année 1863. Phonétique et étymologie: précédé d'une notice sur la vie et les ouvrages de M. Max Müller. Traduit de l'anglais par M. Georges Harris et M. Georges Perrot. Paris: Durand et Pedone Lauriel.

MUNANGA, Kabengele (Org.). Cem anos e mais de bibliografia sobre o negro no Brasil. 1. ed. Brasília: Fundação Cultural Palmares, 2003.

MURRAY, O. S. Theory groups and the study of language in North America: a social history. Amsterdam: John Benjamins, 1994.

MUSSA, Alberto. O papel das línguas africanas na história do português do Brasil. Rio de Janeiro, 1991. Dissertação (Mestrado em Linguística) - Faculdade de Letras, Universidade Federal do Rio de Janeiro.

MYERS-SCOTTON, Carol, and Janice L. Jake. Explaining aspects of codeswitching and their implications. In: One Mind, Two Languages: Bilingual Language Processing, NICHOL, Janet (ed.). Oxford: Blackwell, p. 91-125, 2000a.

MYERS-SCOTTON, Carol, and Janice L. Jake. Four types of morphemes: Evidence from aphasia, codeswitching and second language acquisition. Linguistics, 38, p. 0531100, 2000b.

MYERS-SCOTTON, Carol. Contact Linguistics: Bilingual Encounters and Grammatical Outcomes. Oxford: Oxford University Press, 2002.

NARO, Anthony Julius. Estudos diacrônicos. Vol. 9. Petrópolis: Editora Vozes, 1973.

NARO, Anthony; SCHERRE, Marta. Crioulização e mudança natural. Estudos diacrônicos. Petrópolis: Vozes, 1973.

NARO, Anthony Julius. Tendências atuais da lingüística e da filogia no Brasil. Rio de Janeiro: Livraria F. Alves Editora, 1976.

NARO, Anthony. A study on the origins of pidgnization. Language, 54 (2): 1978, p. 314-347. 
NARO, Anthony; SCHERRE, Marta. Sobre as origens do português falado no Brasil. Rio de Janeiro: Sauer, 1993.

NARO, Anthony; SCHERRE, Marta. 2007. Origens do português brasileiro. São Paulo: Parábola.

NARO, Anthony Julius; SCHERRE, Maria Marta Pereira. Origens do Português Brasileiro. DELTA. Documentação de Estudos em Lingüística Teórica e Aplicada, São Paulo, v. 9, p. 437-454, 1993. Publicado também em Sobre as origens do português popular do Brasil. In: Naro, Anthony Julius; SCHERRE, Maria Marta Perreira. Origens do Português Brasileiro. São Paulo: Parábola Editorial, p. 25-48, 2007.

NARO, Anthony Julius; SCHERRE, Maria Marta Pereira. Concordância variável em português: a situação no Brasil e em Portugal. ABRALIN (Curitiba), Florianópolis, p. 1259-1270, 2000.

NARO, Anthony; SCHERRE, Marta. Variable concord in Portuguese: the situation inBrazil and Portugal. In: McWHORTER, J. (Ed.). Language change and language contact inpidgins and creoles. Amsterdam: John Benjamins, 2000, p.235-256.

NARO, Anthony Julius; SCHERRE, Maria Marta Pereira. Variable concord in Portuguese: the situation in Brazil and Portugal. In: MCWHORTER, John. (Org.). Language change and language contact in pidgins and creoles. Amsterdam/Philadelphia: John Benjamins, v. 21, p. 235-255, 2000. Publicado também em: Concordância Variável em Português: a situação no Brasil e em Portugual. In: Naro, Anthony Julius; SCHERRE, Maria Marta Perreira. Origens do Português Brasileiro. São Paulo: Parábola Editorial, p. 49-69, 2007.

NARO, Anthony Julius; SCHERRE, Maria Marta Pereira. O conceito de transmissão lingüística irregular e as origens estruturais do português brasileiro: um tema em debate. In: RONCARATI, Cláudia; ABRAÇADO, Jussara. (Org.). Português brasileiro contato lingüístico, heterogeneidade e história. Rio de Janeiro: Viveiros de Castro Editora, p. 285-382, 2003. Publicado também em O conceito de transmissão linguística irregular e as origens estruturais do Português brasileiro. In: NARO, Anthony Julius; SCHERRE, Maria Marta Pereira. Origens do português brasileiro. São Paulo: Parábola, p.135-159, 2007. 
NARO, Anthony Julius; SCHERRE, Maria Marta Pereira. Preenchimento do sujeito pronominal e concordância variável no português brasileiro. Origens do português brasileiro. São Paulo: Parábola, 2007, p.161-177.

NARO, Anthony Julius; SCHERRE, Maria Marta Pereira. Fluxos e contrafluxos movimentos sociolinguísticos da comunidade de fala brasileira. In: MOLLICA, Maria Cecília de Magalhães. (Org.). Usos da linguagem e sua relação com a mente humana. Rio de Janeiro: Tempo Brasileiro, 2010, p. 79-91.

NASCENTES, Antenor. O linguajar carioca em 1922. Rio de Janeiro: Organização Simões, 1922.

NASCENTES, Antenor. O Idioma Nacional. Volume I, $2^{\text {a }}$ edição. Rio de Janeiro: A encadernadora, 1927.

NASCIMENTO, Lúcia Valéria do. A África no Serro Frio: vissungos de Milho Verde e São João da Chapada. Belo Horizonte, 2003. Dissertação (Mestrado em Linguística) Faculdade de Letras, Universidade Federal de Minas Gerais.

NAVARRO, Eduardo de Almeida. A expansão colonial e o estudo das línguas exóticas pelos europeus nos séculos XV e XVII: o caso da África. África: revista do Centro de Estudos Africanos. São Paulo: USP, no 22-2, p. 223-231, 1999/2000/2001. http://www.fflch.usp.br/cea/revista/africa_022/af13.pdf

NEGRÃO, Esmeralda Vailati; VIOTTI, Evani Carvalho. A estrutura sintática das sentenças absolutas no português brasileiro. Lingüistica (Madrid), v. 23, p. 37-58, 2010.

NEGRÃO, Esmeralda; VIOTTI, Evani Carvalho. Estratégias de impessoalização no português brasileiro. In: FIORIN, José Luiz; PETTER, Margarida Maria Taddoni (Eds.). África no Brasil: a formação da língua portuguesa, São Paulo, Contexto:179203, 2008.

NEIVA, Arthur. Estudos da Língua Nacional. São Paulo: Companhia Editora Nacional, Coleção Braziliana, vol. 178, 1940. Disponível em: http://www.brasiliana.com.br/brasiliana/colecao/obras/129/estudos-da-lingua-nacional Acesso em: 21/02/2013. 
OLIVEIRA, Klebson. Textos escritos por africanos e afrodescendentes na Bahia do século XIX: fontes do nosso latim vulgar?. Salvador, 2003. Dissertação (Mestrado em Letras e Linguística) - Instituto de Letras, Universidade Federal da Bahia.

OLIVEIRA, Klebson. O lugar do branco na escrita de negros: notas sobre segmentação gráfica em textos de africanos e afrodescendentes no Brasil do século XIX. Revista Internacional de Lingüística Iberoamericana, Berlim/Madrid, v. 1, p. 153-170, 2005.

OLIVEIRA, Klebson. Aquisição da escrita em textos de africanos e afrodescendentes no Brasil do século XIX: grafias para sílabas complexas, por exemplo. In: LOBO, Tânia; RIBEIRO, Ilza; CARNEIRO, Zenaide; ALMEIDA, Norma. (Org.). Para a história do português brasileiro. Volume VI: novos dados, novas análises. Salvador: EDUFBA, v. I, 2006, p. 469-494.

OLIVEIRA, Klebson. Negros e escrita no Brasil do século XIX: sócio-história, edição filológica de documentos e estudo lingüístico. Salvador, 2006. Tese (Doutorado em Letras e Linguística) - Instituto de Letras, Universidade Federal da Bahia.

OLIVEIRA, Klebson. A escrita que mascara e desmascara: alteamento de vogais átonas em textos brasileiros oitocentistas. Interdisciplinar - Revista de Estudos de Língua e Literatura, v. 4, 2007, p. 44-57.

OLIVEIRA, Klebson. Ajuntamento de fontes para a história do português popular brasileiro: amores, desamores e outras espécies de dores. Cadernos de Estudos Lingüísticos (UNICAMP), v. 50 (2), 2008, p. 217-230.

OLIVEIRA, Klebson. Rotacismos e outras rotas: fenômenos com as consoantes líquidas em textos escritos por africanos e afro-descendentes no Brasil do século XIX. Estudos (UFBA), v. 37/38, 2008, p. 227-260.

OLIVEIRA, Klebson. Textos de escravos no Brasil oitocentista: os tempos de uma edição filológica e de uma antologia comentada de alguns fatos lingüísticos. Filologia e Lingüística Portuguesa, v. 10/11, p. 189-220, 2009.

OLIVEIRA, Klebson. Fontes para a história do português popular brasileiro: partidas e contrapartidas. Revista Internacional de Lingüística Iberoamericana, v. 16, 2010, p. 928. 
OLIVEIRA, Klebson; LOBO, Tânia. Introdução ou sobre como a África, no Brasil, a vista a escrita. In: LOBO, Tânia; OLIVEIRA, Klebson (Orgs). África à vista: dez estudos sobre o português escrito por africanos no Brasil do século XIX. Salvador: EDUFBA, p. 6-49, 2009.

OLIVEIRA, Klebson; SOLEDADE, Juliana; SANTOS, Verônica de Souza. Concordância Nominal (cenas da variação em palcos do século XIX). In: LOBO, Tânia; OLIVEIRA, Klebson (Orgs). África à vista: dez estudos sobre o português escrito por africanos no Brasil do século XIX. Salvador: EDUFBA, p. 255-316. 2009.

OLIVEIRA, Márcia Santos Duarte. Algumas considerações sobre a importância da continuidade de estudos etnolinguísticos africanos para o conhecimento da etnolinguística brasileira. In: SILVA, Maria do Perpétuo S. Cardoso. (Org.). As interfaces dos estudos linguísticos. Belém: EDUNAMA, 2008, v. 4, p. 105-110.

OLIVEIRA, Márcia Santos Duarte. Línguas africanas - breves considerações sobre seu conhecimento e pesquisa e sua relação com o português do Brasil. Guavira Letras, v. 6, p. 53-66, 2008.

OLIVEIRA, Márcia Santos Duarte. O impacto da cultura negra na constituição do novo mundo: a contribuição dos 'povos/línguas do Grupo Ibom' (povos de Calabar). In: MORAES, Maria Aparecida Torres; ANDRADE, Maria Lucia Oliveira. (Org.). História do Português Paulista. São Paulo: FAPESP, v. 2, p. 262-272, 2009.

OLIVEIRA, Márcia Santos Duarte; FERNANDES, Jonas Tadeu Viccari. Aspectos Etnolinguísticos da Fala de uma Comunidade Quilombola do Pará: Jurussaca. Cadernos Ceru (USP), v. 21, p. 13-32, 2010.

OLIVEIRA, Márcia Santos Duarte; JORGE, Lurdes. A categoria tempo e a interface discurso/gramática - foco em português: investigações preliminares à luz de um fenômeno areal africano. In: CORTINA, Arnaldo; NASSER, Sônia Maria G. da C. (Org.). Sujeito e Linguagem. São Paulo: Cultura Acadêmica, v. 17, p. 75-96, 2009.

OLIVEIRA, Marilza. PB do século XIX: uma Brasiláfrica lingüística?. In: LOBO, Tânia; RIBEIRO, Ilza; CARNEIRO, Zenaide, ALMEIDA, Norma. (Org.). Para a História do Português Brasileiro. Salvador: UFBA, 2006. 
OLIVEIRA, Waldir Freitas. Desenvolvimento dos estudos africanistas no Brasil. Cultura, Brasília: MEC, v.6, n.23, p.110-117, out./dez. 1976.

ORTIZ, Fernando. "La africanía de la música folklórica de Cuba". Havana, Cuba, 1950.

ORTIZ, Fernando. Glosario de afronegrismos. Editorial de Ciencias Sociales, 1924.

PAGOTTO, Emilio. Crioulo sim, crioulo não: uma agenda de problemas. In: CASTILHO, Ataliba T. de; LOPES, Ruth E. Vasconcellos; TORRES MORAIS, Maria Aparecida; CYRINO, Sônia Maria Lazzarini. (Org.). Português Brasileiro: Descrição, História e Aquisição. 1ª.ed.Campinas: Pontes, 2007, v. 1, p. 461-482.

PAL, Dayane Cristina. "Aí fui inu, fui inu, aí peguei arrumei uma casa no capoava lá". Construções seriais em português brasileiro: estudo com dados da comunidade negra de Pedro Cubas, Vale do Ribeira/SP. São Paulo, 2005. Dissertação (Mestrado em Linguística) - Faculdade de Filosofia, Letras e Ciências Humanas, Universidade de São Paulo.

PEREIRA, Eduardo Carlos. 1919. Grammatica historica. $2^{\mathrm{a}}$ ed. aumentada, Rio de Janeiro, Besnard.

PETTER, Margarida Maria Taddoni. Profil sociolinguistique des élèves du CM2. 1984. Dissertação (Mestrado em Linguística) - Université Nationale de Côte D'ivoire.

PETTER, Margarida Maria Taddoni. 1992. A construção do sgnificado de fÀni, 'pano e vestuário', em diulá. Tese (Doutorado em Linguística) - Universidade de São Paulo.

PETTER, Maria Margarida Taddoni. Perspectivas para o estudo de língua africanas no Brasil. Boletim da Associação Brasileira de Lingüística, São Paulo, v. 1. p. 325-332, 1993.

PETTER, Maria Margarida Taddoni. A contribuição das comunidades negras isoladas para a caracterização do português brasileiro. Estudos Lingüísticos (São Paulo), Ribeirão Preto, v. XXIV, p. 543-549, 1995. 
PETTER, Maria Margarida Taddoni. Línguas especiais, línguas secretas: na África e no Brasil. Revista da ANPOLL, São Paulo, v. 4, p. 185-202, 1998.

PETTER, Maria Margarida Taddoni. A presença de línguas africanas no português do Brasil. Estudos Lingüísticos (São Paulo), São José do Rio Preto, v. XXVII, p. 777-783, 1998.

PETTER, Maria Margarida Taddoni. A linguagem do Cafundó: crioulo ou anticrioulo?. In: ZIMMERMAN, Klaus. (Org.). Lenguas criollas de base lexical española y portuguesa. Vervuert: Iberoamericana, v. 1, p. 101-118, 1999.

PETTER, Maria Margarida Taddoni. Talvez sejam africanismos. Estudos Lingüísticos (São Paulo), Assis, v. XXIX, p. 713-718, 2000.

PETTER, Margarida Maria Taddoni. Africanismos no Português do Brasil. In: ORLANDI, Eni. (Org.). História das Idéias Lingüísticas: Construção do saber metalingüístico e constituição da Língua Nacional. $1^{a}$ ed. Campinas: Pontes, Cáceres: UNEMAT Editora, p. 223-234, 2001.

PETTER, Margarida Maria. Taddoni. Seriam traços de línguas africanas no português do Brasil. Estudos Lingüísticos (São Paulo), Marília, v. XXX, p. 67-72, 2001.

PETTER, Margarida Maria Taddoni. Termos de origem africana no léxico do português do Brasil. In: NUNES, José Horta; PETTER, Margarida Maria Taddoni. (Org.). História do saber lexical e constituição de um léxico brasileiro. $1^{\mathrm{a}}$ ed. São Paulo: Humanitas/FFLCH/USP; Pontes, 2002, p. 123-146.

PETTER, Margarida Maria Taddoni; HONÓRIO, Maria Aparecida; FERREIRA, Mário; NUNES, José Horta. A constituição do léxico nacional - problemas de línguas em contato. Estudos Lingüísticos (São Paulo), São Paulo, v. XXXI, p. 106-112, 2002.

PETTER, Margarida Maria Taddoni. A fala da comunidade do Cangume: alguns traços fonéticos específicos. ABRALIN (Curitiba), Fortaleza, v. 2, p. 359-361, 2003.

PETTER, Margarida Maria Taddoni. Contact des langues au Brésil: les langues africaines et le portugais brésilien. In: AKINBIYI, Akindabi; OLUSEYE, Adesola. (Org.). Proceedings of the 4th World Congress of African Linguistics - New Brunswick 2003. Hamburgo: Rüdiger Köppe Verlag, v. 1, p. 234-245, 2004. 
PETTER, Margarida Maria Taddoni. Línguas africanas no Brasil. Gragoatá, Rio de Janeiro, v. 19, p. 193-227, 2005.

PETTER, Margarida Maria Taddoni; ZANONI, Dafne. Quilombos do Vale do Ribeira: variação e mudança na concordância de gênero e de número. Papia, Brasília, v. 15, p. 61-71, 2005.

PETTER, Margarida Maria Taddoni. Línguas Africanas no Brasil. In: CARDOSO, Suzana Alice Marcelino; MOTA, Jacyra Andrade; MATTOS E SILVA Rosa Virgínia. (Org.). Quinhentos Anos de História Lingüística do Brasil. Salvador: Secretaria da Cultura e Turismo do Estado da Bahia, p. 117-142, 2006.

PETTER, Margarida Maria Taddoni. Revista Ilustrada: un document sur le langage des Noirs à la fin du XIXe siècle. In: GUIMARÃES, Eduardo; BARROS, Diana Luz Pessoa de. (Org.). History of Linguistcs 2002: selected papaers from the Nineth International Conference on the History of the Language Sciences, 27-30 autus 2002, São Paulo, Campinas. Amsterdam: John Benjamins, v. 110, p. 87-92, 2007. Disponível em http://www.fflch.usp.br/dl/gela/textos/revista\%20ilustrada.pdf Acesso em: 24/03/2012

PETTER, Margarida Maria Taddoni. Variedades lingüísticas em contato: português angolano, português brasileiro, português moçambicano. São Paulo, 2008. Tese de livre-docência, concurso para a livre docência - Faculdade de Filosofia, Letras e Ciências Humanas, Universidade de São Paulo.

PETTER, Margarida Maria Taddoni. Uma hipótese explicativa do contato entre o português e as línguas africanas. Papia (Brasília), v. 1, p. 9-19, 2008. Disponível em: http://abecs.dominiotemporario.com/ojs/index.php/papia/article/viewFile/6/17-1 Acesso em: 01/03/2013.

PETTER, Margarida Maria Taddoni. O continuum afro-brasileiro do português. In: GALVES, Charlotte; GARMES, Helder; RIBEIRO, Fernando Rosa. (Org.). ÁfricaBrasil: caminhos da língua portuguesa. $1^{\mathrm{a}}$ ed.Campinas: Editora da Unicamp, 2009, p. 159-174.

PETTER, Margarida Maria Taddoni. Línguas africanas no Brasil. África (USP), v. 27/28, p. 63-89, 2010. 
PICALLO, M. Carme. "Nominals and nominalizations in Catalan". Probus 3.3, 1991, 279-316.

PINTO, Edith Pimentel. O português do Brasil: textos críticos e teóricos, 1820-1920, fontes para a teoria e história. São Paulo: Editora da Universidade de São Paulo, 1978.

PINTO, Edith Pimentel.O português do Brasil: textos críticos e teóricos, 1920-1945, fontes para a teoria e história. São Paulo: Editora da Universidade de São Paulo, 1981.

PINTZUK, Susan. VARBRUL programs. Philadelphia: University of Pennsylvania Department of Linguistics, 1988.

PONTES, Hildebrando Araújo. Influência da linguagem africana do negro na formação do “dialeto capiáu”. Jornal do Commercio, Rio de Janeiro, 24 de agosto 1921.

QUEIROZ, Sônia. A língua do negro da costa: um remanescente africano em Bom Despacho (MG). Belo Horizonte, 1984. Dissertação (Mestrado em Linguística) Faculdade de Letras, Universidade Federal de Minas Gerais.

QUEIROZ, Sônia. A língua do negro da Costa: um pidgin em Minas Gerais?. Duas Palavras, Belo Horizonte, v. 1, n.2, 1985, p. 17-21.

QUEIROZ, Sônia. A língua do Negro da Costa: um pidgin em Minas Gerais?. Boletim do Cesp, Belo Horizonte, v. 13, n.15, 1986, p. 94-105.

QUEIROZ, Sônia. A língua dos negros da Tabatinga. Minas Gerais - Suplemento Literário, Belo Horizonte, v. 1033, 1986.

QUEIROZ, Sônia. Pé Preto no Barro Branco: a Língua dos Negros da Tabatinga. Belo Horizonte: UFMG, 1998.

QUEIROZ, Sônia. Remanescentes culturais africanos no Brasil. Aletria, Belo Horizonte, 2002, p. 48-60.

QUEIROZ, Sônia. Palavra africana em Minas Gerais. In: SEABRA, Maria Cândida Trindade Costa de. (Org.). Léxico em estudo. Belo Horizonte: Faculdade de Letras da UFMG, v. 1, p. 59-74, 2006. 
QUEIROZ, Sônia. Vozes da África em terras diamantinas. Minas Gerais, Suplemento Literário, v. 1, p. 1-3, 2008.

RAIMUNDO, Jacques. O elemento afro-negro da Língua Portuguesa. Rio de Janeiro: Renascença Editora, 1933.

RAIMUNDO, Jacques. O negro brasileiro e outros escritos. Rio de Janeiro: Record, 1936.

RAIMUNDO, Jacques. Sugestões. In: HERSKOVITS, M. J. et al. O negro no Brasil; trabalhos apresentados ao II Congresso Afro-Brasileiro (Bahia). Rio de Janeiro: Civilização Brasileira, p.359-363, 1940. (Biblioteca de Divulgação Científica, 20).

RAIMUNDO, Jacques. A língua portuguesa no Brasil. (Expansão, penetração, unidade e estado atual). Rio de Janeiro: Imprensa Nacional, 1946.

RAMOS, Arthur. As culturas negras no novo mundo. Rio de Janeiro: Civilização Brasileira, 1937.

RAMOS, Arthur. A aculturação negra no Brasil. Rio de Janeiro: Companhia editora nacional, 1942.

RAMOS, Arthur. Nina Rodrigues e os estudos negro-brasileiros. In: HERSKOVITS, Melville J. et al. O negro no Brasil; trabalhos apresentados ao II Congresso AfroBrasileiro (Bahia), Rio de Janeiro: Civilização Brasileira, p. 337-339, 1940. (Biblioteca de Divulgação Científica, 20).

RASO, Tomasso; MELLO, Heliana. As especificidades da unidade de tópico em PB e possíveis efeitos do contato linguístico. In: SARAIVA, Maria Elizabeth Fonseca; MARINHO, Janice Helena Chaves (Org.). Estudos da língua em uso. Belo Horizonte: Editora UFMG, 2010.

Revista Brasileira de Folclore, Rio de Janeiro, MEC, Campanha de Defesa do Folclore Brasileiro, v.8, n. 21, p.119-128, maio/ago. 1968. http://docvirt.com/atualizacao/goglobal/formFF.asp 
REVISTA DA ACADEMIA FLUMINENSE DE LETRAS. Niterói, volumes 11-14, 1960.

REZENDE, Garcia de. Cancioneiro geral. Von Kausler, Eduard Heinrich (Ed.). Stuttgart: Kausler, 1846/1852.

RIBEIRO, Ilza. O papel do traço [+acordo] em construções com o infinitivo flexionado. 1988. Dissertação (Mestrado em Letras e Linguística) - Universidade Federal da Bahia.

RIBEIRO, Ilza. O efeito V2 no português arcaico. Campinas, 1995. Tese (Doutorado em Linguística) - Universidade de Campinas.

RIBEIRO, Ilza; FIGUEIREDO, Cristina. As sentenças relativas em Atas escritas por africanos, no Brasil oitocentista (1832-1842). Salvador, 2006. Ms.

RIBEIRO, Ilza. O sujeito nulo referencial no português popular brasileiro - século XIX. In: MORAIS, Maria Aparecida Torres; ANDRADE, Maria Lucia Oliveira. (Org.). História do Português Paulista: Série Estudos (no prelo). Campinas: Editora da UNICAMP, 2008, v. 2.

RIBEIRO, Ilza; FIGUEIREDO, Maria Cristina. Orações relativas em textos de africanos na Bahia oitocentista. In: MEIRA, Vivian. (Org.). Português Brasileiro: estudos funcionalistas e sociolinguistas. Salvador: EDUNEB, p. 146-175, 2008.

RIBEIRO, Ilza. As sentenças relativas. In: LUCCHESI, Dante; BAXTER, Alan; RIBEIRO, Ilza. (Org.). O português afro-brasileiro. Salvador: EDUFBA, p. 185-208, 2009.

RIBEIRO, Ilza; CÔRTES JUNIOR, Moacir. As construções pseudo-clivadas e clivadas. In: LUCCHESI, Dante; BAXTER, Alan; RIBEIRO, Ilza. (Org.). O português afrobrasileiro. Salvador: EDUFBA, p. 209-230, 2009.

RIBEIRO, Ilza; FIGUEIREDO, Maria Cristina. Relativas. In: África à vista. Dez estudos sobre o português escrito por africanos no Brasil do século XIX. Salvador: EDUFBA, 2009, p. 208-240. 
RIBEIRO, João. Diccionario grammatical. Rio de Janeiro: Francisco Alves, 1906[1897].

RIBEIRO, João. A língua nacional e outros estudos lingüísticos. Seleção e coord. de Hildon Rocha. Petrópolis: Vozes/Aracaju: Governo do Estado de Sergipe, 1979[1921].

RIBEIRO, João. O elemento negro: História, Folklore e Linguística. Petrópolis: Editora Record, 1930.

RIBEIRO, João. História do Brasil. Rio de Janeiro: Livraria Francisco Alves, 1935.

ROCHA DA SILVA, Claudia. Variação linguística e leitura de quilombolas na Bahia: o caso de barra do brumado. In: OLIVEIRA, Iolanda de; AGUIAR, Márcia Ângela da Silva; SILVA, Petronilha Beatriz; OLIVEIRA, Raquel de. (Org.). Negro e educação 4: linguagens, resistências e políticas públicas. SÃO PAULO: ANPED; AÇÃO EDUCATIVA, 2007.

ROCHA DA SILVA, Cláudia. Vozes do Silêncio: a linguagem quilombola e o preconceito lingüístico-racial em Rio de Contas na Bahia. Salvador, 2008. Dissertação (Mestrado em Educação e Contemporaneidade) - Universidade do Estado da Bahia.

RODRIGUES, Ada Natal. O dialeto caipira na região de Piracicaba. São Paulo: Ática, 1974. (Col. Ensaios, 5).

RODRIGUES, Aryon. Dall'Igna. As línguas gerais sul-africanas. Papia - Revista de Crioulos de Base Ibérica. Brasília: Thesaurus, n 4, 1996, pp. 6-18.

RODRIGUES, Nina. Os africanos no Brasil. São Paulo: Nacional, 1932.

RODRIGUES, Raymundo Nina. Os africanos no Brasil. São Paulo: Nacional, 1932.

ROMERO, Sílvio. Folclore brasileiro: Cantos populares do Brasil. 2 v (Vol. 1). Rio de Janeiro: Olympio, 1954.

ROQUETTE-PINTO, Edgard. Seixos rolados (estudos brasileiros). Mendonça, Machado \& C, 1927.

ROSSI, Nelson. Atlas prévio dos falares baianos. [Rio de Janeiro]: MEC/INL, 1963. 
SÁ, Filippe Franco de. A língua portuguesa: dificuldades e dúvidas. São Luís: Imprensa Officia, 1915.

SAINT HILAIRE, Auguste. Viagem ao Rio Grande do Sul (1820-1821). São Paulo: Companhia editora Nacional, 1939(1820).

SANCHES, Edgard. Língua brasileira. São Paulo/Rio de Janeiro/Recife/Porto Alegre: Cia. Editora Nacional, 1940.

SANKOFF, David; TAGLIAMONTE, Sali; SMITH, Eric. "Goldvarb X: A variable rule application for Macintosh and Windows." Department of Linguistics, University of Toronto, 2005.

SAPIR, Edward. Language: an introduction to the study of speech. New York: Harcount, Brace and Co, 1921.

SAPIR, Edward. “Dialect”. Encyclopedia of the Social Sciences, v. 5, 1931, p. 123-126.

SARDINA MIMOSO, João. Relación de la Real tragicomedia con que los padres de la Compañía de Iesus en su Colegio de S. Anton de Lisboa recibieron a la Magestad Católica de Felipe II de Portugal, y de su entrada en este Reino.... Impresso en Lisboa: por Jorge Rodriguez. 1620.

SAUSSURE, Fernand de. Curso de lingüística geral. Organizado por Charles Bally, Albert Sechehaye; com a colaboração de Albert Riedlinger ; prefácio à edição brasileira Isaac Nicolau Salum ; tradução de Antônio Chelini, José Paulo Paes, Izidoro Blikstein. São Paulo: Cultrix, 2008[1916].

SCHERRE, Marta. 1973. A Regra de Concordância de Número no Sintagma Nominal em Português. Dissertação (Mestrado em Linguística) - Pontifícia Universidade Católica, Rio de Janeiro.

SCHERRE, Marta. 1978. A Regra de Concordância de Número no Sintagma Nominal em Português.

SCHERRE, Marta. 1988. Reanálise da concordância nominal em português. Tese de doutoramento. Rio de Janeiro: UFRJ. 
SCHERRE, Marta. 1998a. Variação da concordância nominal no Português do Brasil: influência das variáveis posição, classe gramatical e marcas precedentes. In: GROBE, S.; ZIMMERMANN, k. (Orgs.) Substandard e mudança no português do Brasil. frankfurt am Main: TFM, v. 6, p. 153-188.

SCHERRE, Maria Marta Pereira. Doa-se lindos filhotes de'poodle': variação lingüística, mídia e preconceito. Vol. 12. São Paulo: Parábola, 2005.

SCHERRE, Maria Marta Pereira. Speech Community. In: BROWN, Keith. (Org.). Encyclopedia of Language \& Linguistics (ELL2). 2ed. Oxford: Elsevier, 2006, v. 11, p. 716-722.

SCHERRE, Maria Marta Pereira; NARO, Anthony Julius. Ampliando os horizontes do debate sobre as origens da concordância variável no Português Brasileiro. Origens do Português Brasileiro. São Paulo: Parábola Editorial, p. 87-116, 2007.

SCHERRE, Maria Marta Pereira; NARO, Anthony Julius. Sobre as origens do Português Brasileiro: garimpo fonológico. Origens do Português Brasileiro. São Paulo: Parábola Editorial, p. 117-113, 2007. Publicado também em: SCHERRE, Maria Marta Pereira; NARO, Anthony Julius. Sobre as origens estruturais do português brasileiro - o garimpo continua. In: CARVALHO, Ana Maria. (Org.). Português em Contato Lingüística luso-brasileira, 2. Madrid/Frankfurt am Main: IBEROAMERICANA/EDITORIAL VERVUERT, 2009, v. 1, p. 131-151.

SCHERRE, Maria Marta Pereira; NARO, Anthony Julius. Sobre as origens estruturais do português brasileiro: crioulização ou mudança natural? Papia (Brasília), Brasília, v. 11, p. 41-50, 2001. Publicado também em: Garimpando as origens do Português brasileiro: sobre três estruturas linguísticas radicais. In: SCHERRE, Maria Marta Pereira; NARO Anthony Julius (Org.). Origens do Português Brasileiro. São Paulo: Parábola Editorial, p. 71-85, 2007.

SENNA, Nelson de. Africanismos no Brasil. Revista de Língua Portuguesa, n.10, p.159-163, mar. 1921.

SENNA, Nelson de. Contribuições para a ethnologia brasileira: os negros (elementos de origem africana e seus descendentes). Revista de Língua Portuguesa, n.22, p.136-149, mar. 1923. 
SENNA, Nelson de. Africanos no Brasil: estudos sobre os negros africanos $e$ influências sobre a linguagem e costumes do povo brasileiro. Belo Horizonte: Of. Gráf. Queiroz Breyner, 1938.

SILVA NETO, Serafim da. A origem do dialeto brasileiro. Revista Filológica. 9, p. 4549, 1941.

SILVA NETO, Serafim da. 1950. Introdução ao estudo da língua portuguesa no Brasil. Rio de Janeiro: Presença.

SILVA NETO, Serafim da. História da língua portuguêsa. Florianópolis: Faculdade Catarinense de Filosofia, 1955.

SILVA NETO, Serafim da. A língua portuguesa no Brasil: problemas. Rio de Janeiro: Acadêmica, 1960.

SILVA NETO, Serafim da.. História da Língua Portuguesa. Rio de Janeiro: Editorial Presença, 1986.

SILVA, Deijair Ferreira da. O futuro em Helvécia e em Cinzento: um estudo do uso das formas simples e perifrásticas no português rural afro-brasileiro. Salvador, 2003. Dissertação (Mestrado em Letras e Linguística), Universidade Federal da Bahia.

SILVA, Jorge Augusto Alves da. A concordância verbal no português afro-brasileiro: um estudo sociolinguístico de três comunidades rurais do Estado da Bahia. Salvador, 2003. Dissertação (Mestrado em Linguística) - Universidade Federal da Bahia, Salvador.

SILVA, Jorge Augusto Alves da. A concordância verbal de terceira pessoa do plural no português popular do Brasil: um panorama sociolingüístico de três comunidades do interior do estado da Bahia. Salvador, 2006. Tese (Doutorado em Linguística) Universidade Federal da Bahia, Salvador.

SILVA, Maria Eunice Rosa de Jesus. Rememorando a Chapada Diamantina: Histórias do Mulungu. Salvador, 2006. Dissertação (Mestrado em Educação e Contemporaneidade) - Universidade do Estado da Bahia.

SILVEIRA BUENO, Francisco. A formação histórica da língua portuguesa. São Paulo: Saraiva, 1967. 
SLENES, Robert Wayne Andrew. "Malungu, ngoma vem!": África coberta e descoberta do Brasil. Revista da USP, número 12: 48-67, 1992. Disponível em: http://www.usp.br/revistausp/12/06-robert.pdf. Acesso em 18/03/13.

SOUZA, Antonio Carlos Santana de. A concordância de gênero entre o sujeito e o predicativo na fala da comunidade quilombola da Caçandoca. São Paulo, 2000. Dissertação (Mestrado em Lingüística) - Faculdade de Filosofia, Letras e Ciências Humanas, Universidade de São Paulo.

SOUZA, Antonio Carlos Santana de. A influência das variáveis sociais numa pesquisa sociolingüística em comunidades negras rurais. Interletras, Dourados, v. 2, p. 1-13, 2009.

SOUZA, Antonio Carlos Santana de. Tradições discursivas e o estudo dos corpora de língua falada nas comunidades quilombolas de Mato Grosso do Sul. Web revista: questões de lingüística e de linguagem, v. 1, p. 300-312, 2009.

SOUZA, Antonio Carlos Santana de; SCHLIECK, Cleonice. Comunidades afrobrasileiras isoladas em Mato Grosso do Sul: um estudo sociolinguístico dos quilombos de Tia Eva e Furnas dos Dionísios. Web-revista: questões de lingüística e de linguagem, v. 1, p. 1-13, 2009.

SPERA, Jeane Mari Sant'Ana; RIBEIRO, João Roberto Inácio. O falar da comunidade negra de João Ramalho. Alfa ((ILCSE/UNESP), São Paulo, volume 33, p. 147-154, 1989. Disponível em: http://seer.fclar.unesp.br/alfa/article/view/3816/3523 Acesso em: $21 / 03 / 2013$.

SWIGGERS, Pierre. The History-writing of Linguistics: A Methodological Note. General Linguistics 21, v.1, 1981 a, p.11-16.

SWIGGERS, Pierre. L'historiographie des sciences du langage: intérêts et programmes. International Congress of Linguistics, 14, 1987 (August 10 - August 15), Berlin/GDR, Proceedings, Berlin: Akademie-Verlag, p. 2713-2716, 1991a.

SWIGGERS, Pierre. Modelos, métodos y problemas en la historiografía de la lingüística. Nuevas aportaciones a la historiografía lingüística. Actas del IV Congreso 
Internacional de la SEHL. La Laguna (Tenerife), 22-25 octubre de 2003, ed. Corrales Zumbado, C; Dorta Luis, J. et al. Madrid: Arco Libros, 2004, p. 113-145.

SWIGGERS, Pierre. La historiografia de la lingüística: apuntes y reflexiones. Revista Argentina de historiografía lingüística, I, 2009, 67-76.

SWIGGERS, Pierre. História e Historiografia da Linguística: Status, Modelos e Classificações. Tradução de Cristina Altman. Eutomia, Recife, ano III, v. 2, 2011, p. 117.

SWIGGERS, Pierre. A Historiografia da Linguística: objeto, objetivos e organização. Revista Confluência: Revista do Instituto de Língua Portuguesa, $n^{\circ} 44-5,1^{\circ}$ e $2^{\circ}$ semestres de 2013, p. 39-59.

TARALLO, Fernando. "Sobre a alegada origem crioula do português brasileiro: mudanças sintáticas aleatórias". IN: ROBERTS, Ian; KATO, Mary (org.) O português brasileiro: uma viagem diacrônica. Homenagem a Fernando Tarallo. Campinas: Unicamp, p. 35-68, 1993.

TARALLO, Fernando. "Sobre a alegada origem crioula do português brasileiro: mudanças sintáticas aleatórias”. In: ROBERTS, Ian; KATO, Mary (orgs). O português brasileiro: uma viagem diacrônica. Homenagem a Fernando Tarallo. Campinas: UNICAMP, 1993[1986], p. 35-68.

TARALLO, Fernando. On the allege creoule origin of Brazilian Portuguese: Untargeted Syntatic Change. Trabalho apresentado no Creole Worshop, LSA Institute, City University of New York, 1986.

TARALLO, Fernando; ALKMIN, Tânia. Falares crioulos: línguas em contato. São Paulo: Ática, 1987.

TESSIER, Paul. La langue de Gil Vicente. Paris: C. Klincksieck, 1959.

THOMASON, Sarah G.; KAUFMAN, Terrence. Language contact, creolization and Genetic Linguistics. Berkeley: University of California Press, 1988. 
TRINDADE-SERRA, Ordep José. Dois estudos afro-brasileiros. Salvador: Centro Editorial e Didatico da UFBA, 1988.

UMBELINO DE BARROS, Elizabete. Traços de Quimbundo em uma comunidade religiosa. Papia (Brasília), v. 15, p. 116-120, 2005.

UMBELINO DE BARROS, Elizabete. Traços do kimbundu numa Casa de Candomblé Angola. São Paulo, 2001. Dissertação (Mestrado em Lingüística) - Faculdade de Filosofia, Letras e Ciências Humanas, Universidade de São Paulo.

VAN COETSEM, Frans. A General and Unified Theory of the Transmission Process in Language Contact. Heidelberg: Universitatsverlag, C. Winter, 2000.

VASCONCELOS, Carolina de Michaelis. Notas vicentinas. Lisboa: Caminho, 1923.

VENDRYES, Joseph. Le langage: Introduction Linguistique a L'histoire. Paris: A. Michel, 1921.

VIARO, Mário Eduardo. Palavras africanas... será?. Discutindo Língua Portuguesa, v. 1, p. 58-60, 2005.

VICENTE, Frei do Salvador. Historia do Brazil [1500-1627]. Rio de Janeiro: Typ de Leuzinger \& filhos, 1889[1697].

VIEIRA, Frei Domingos. (1871-1874). Grande Diccionario Portuguez ou Thesouro da Lingua Portugueza. Porto : Ernesto Chardron e Bartolomeu H de Moraes, 1971.

VIEIRA, Sílvia. A não concordância em dialetos populares: uma regra variável. Grafos, João Pessoa, n. 2, v. 1, p. 115-34, 1997.

VOGT, Carlos, FRY, Peter. Cafundó: a África no Brasil: língua e sociedade. São Paulo: Companhia das Letras/ Campinas: Editora Unicamp, 1996.

VOGT, Carlos. Cafundó: uma Comunidade Negra no Brasil que fala até hoje uma língua de origem africana. Revista de Estudos Lingüísticos, Bauru, v. 2, p. 11-19, 1978.

VOGT, Carlos; FRY, Peter. Rios de cristal: contos e desencontros de línguas africanas no Brasil. Cadernos de estudos lingüísticos, v. 8, p. 109-128, $1985 \mathrm{~b}$. 
VOGT, Carlos; FRY, Peter. Cafundó: a África no Brasil: língua e sociedade. São Paulo: Companhia das Letras/ Campinas: Editora Unicamp, 1996.

VOGT, Carlos; FRY, Peter. A descoberta do Cafundó e o Kafundó descoberto. Com Ciência, Campinas, v. 17, 2000 Disponível em: http://comciencia.br/reportagens/migracoes/migr12.htm

VOGT, Carlos; FRY, Peter. As formas de expressão na Língua Africana do Cafundó. Ciência e Cultura (SBPC), São Paulo/Campinas, v. 57, no 2, p. 39-42, 2005.

XAVIER, Francisco. Adaptação fonológica dos empréstimos do quimbundo no português brasileiro: abordagem em teoria da otimidade. São Paulo, 2005. Dissertação (Mestrado em Linguística) - Faculdade de Filosofia, Letras e Ciências Humanas, Universidade de São Paulo. 